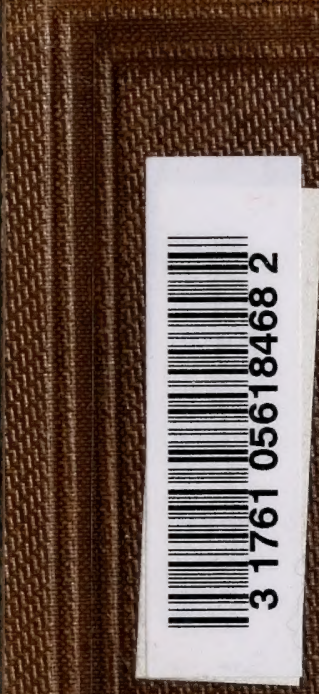





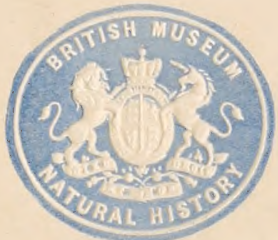

PR IE ST NTED

BY

(2) פrustees

OF

THE BRITISH MUSEUM. 
Digitized by the Internet Archive in 2007 with funding from Microsoft Corporation 


\title{
CATALOGUE
}

$$
\text { OF THE }
$$

\section{MESOZOIC PLANTS}

IN THE

\section{DEPARTMENT OF GEOLOGY}

\author{
PART I.
}





\section{CATALOGUE}

OF THE

\section{MESOZOIC PLANTS}

IN THE

DEPARTMENT OF GEOLOGY

BRITISH MUSEUM

(NATURAL HISTORY).

\section{THE WEALDEN FLORA.}

PART I.-THALLOPHYTA-PTERIDOPHYTA.

PLATES I-XI.

BY

A. C. SEWARD, M.A., F.G.S. UNIVERSITY LECTURER IN BOTANY, CAMBRIDGE.

\section{O N D O N :}

PRINTED BY ORDER OF THE TRUSTEES.

SOLD BY

LONGMANS AND C0., 39, PATERNOSTER ROW.

B. QUARITCH, 15, PICCADHLY. DULAU AND C0., 37, SOHO SQUARE, S.W.

KEGAN PAUL AND CO., CHARING CROSS ROAD, W.c.

AND AT THE

BRITISH MUSEUM (NATURAL HISTORY), CROMWELL ROAD, S.W.

1894. 


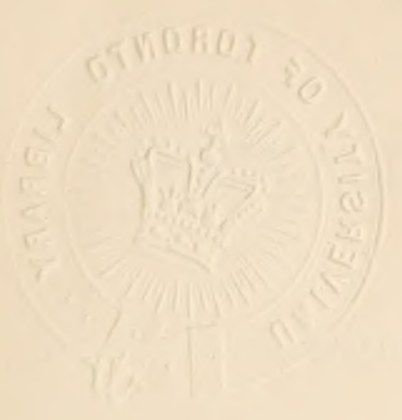

$$
34^{69^{2}}
$$

HERTFORD :

PRINTED BY STEPHEN AUSTIN AND SONS. 


\section{P R E F A C E.}

There is probably no part of England which possesses a greater interest for geologists than that of the Weald. The area in which the Wealden beds are developed extends over a considerable part of Surrey, Sussex and Kent, between Haslemere, Hythe and Pevensey; they are also found in Dorsetshire and the Isle of Wight. But it is more particularly in the neighbourhood of Hastings that the more important fossil remains have been obtained. The beds exhibit evidence of having been accumulated in an estuary or lake, where freshwater conditions prevailed. The Flora includes Coniferæ, Cycads, Ferns, etc., the Fauna Ostracoda (Cypridea); Insect remains; Mollusca (Cyrena, Unio, Melanopsis, Paludina, etc.); Fishes (Lepidotus, Hybodus, etc.); Reptiles (Crocodilia and Dinosauria); Mammals (Plagiaulax).

Our earliest information respecting the strata is mainly due to the labours of Mantell and Fitton.

Stokes and Webb, Robert Brown, Fitton, Brongniart, Dunker, Schimper, Carruthers, Count Solms-Laubach and others have noticed and described its fossil plants, but Mantell's name will always be more particularly associated with the discoveries of organic remains, and with the history of the Wealden area. 
We are fortunate in possessing many of Mantell's original specimens of Wealden plants, but, although historically of great interest, they are largely superseded by those recently obtained by Mr. P. Rufford, whose fine collection has lately been acquired for the National Museum.

It is satisfactory to know that in this country the long-neglected study of the Mesozoic plants is now being taken up by so able a Botanist as Mr. Albert Seward, and that the first instalment of his Catalogue is now complete.

It is expected that the Wealden plants will occupy two fasciculi, and that the Oolitic plants of Yorkshire, of which the Museum possesses exceptionally fine materials obtained by the late Mr. Bean, by Dr. Murray of Scarborough, and other well-known collectors, may be similarly treated by Mr. Seward.

\section{HENRY WOODWARD.}

Department of Geology,

March 10th, 1894. 


\section{AUTHOR'S PREFACE.}

The scope of the present volume is confined to the Thullophyta, Charophytu, Bryophyta, and Pteridophyte represented in the British Museum collections of English Wealden plants. A general review and more critical discussion of the Wealden flora, as a whole, will be attempted in the second volume after the remaining classes of plants have been fully examined.

I desire to express my obligation to Dr. Woodward, Mr. R. Bullen Newton, and other members of the Geological Department for the facilities and help which have been afforded me during my vacation visits to the MIuseum. My thanks are also due to Mr. Carruthers, who has always been ready to place at my disposal his wide knowledge of fossil and recent ferns; to my friend Mr. Geo. Murray I am indebted for generous help; also to other members of the Botanical Department, who have assisted me in various ways.

For information on certain points connected with recent ferns I have availed myself of the exceptional advantages afforded by the Royal Gardens, Kew. 
In certain parts of the work I have received valuable assistance from Mr. C. Davies Sherborn. Mr. Rufford, whose labours have been the primary cause of this Catalogue, has aided me from time to time by helpful suggestions, and by his accurate local knowledge of the Wealden flora in the neighbourhood of Hastings.

In conclusion I wish to express my thanks for communications received from the Marquis of Saporta, Prof. Stenzel of Breslau, Prof. Zeiller of Paris, and Dr. Bommer of Brussels.

\section{A. C. SEWARD.}

Cambridge,

March 13th, 1894. 


\section{INTRODUCTION.}

BeFone proceeding to deal in detail with the fossil plants from the Wealden rocks of England, it may be useful to summarize the results of previous workers in the field of Wealden regetation. After a sketch of the work already published by English geologists and palæobotanists, we will briefly notice those records of fossil plants from other countries which may serve as data, from which to draw conclusions as to the distribution of such floras as agree more or less closely with that of the English Wealden.

The present volume is only concerned with the Thallophyta, Charophyta, Bryophyta and Pteridophyta, but in the lists quoted in the following pages the higher plants are included. In each case the specific names are reproduced unaltered from the writings of the several authors, with the addition of the newer titles in those cases where a change has been proposed in the present Volume.

\section{ENGLAND.}

The term "Wealden" appears to hare been first proposed by P. J. Martin ${ }^{1}$ in 1828, and is a modification of Weald Measures, instituted in 1822 by J. Middleton. ${ }^{2}$ Martin, in his Geological

1 Geol. Men. Sussex, p. 9.

${ }^{2}$ H. B. Woodward, Geol. England and Wales, 1887, p. 356. 
Memoir, ${ }^{1}$ refers to the Wealden as including the Weald clay, Hastings sands, and Tilgate beds. In Topley's exhaustive Memoir on the "Geology of the Weald" the area occupied by the rocks in question is spoken of as "one of the best defined geographical tracts in England. Its boundary is the chalk escarpment, which, commencing at Folkestone Hill, near the Straits of Dover, passes through the counties of Kent, Surrey, Hants and Sussex, to the sea at Beachy Head. The oval-shaped area thus enclosed is what geologists hare termed the Weald." 2

The fossils which form the subject of the present Monograph have been collected from rocks included in the Wealden Series, as defined by H. B. Woodward in his "Geology of England and Wales," that is, in the strata which are "developed over a considerable part of Surrey, Sussex and Kent, between Haslemere, Hythe and Pevensey; they are also found in Dorsetshire and the Isle of Wight."

In looking over the literature of Continental or, rather, extraBritish Lower Cretaceous stratigraphy, we are met with a difficulty in the use of the terms Wealden and Neocomian.

In a recent Monograph on the plants of the Potomac Flora of North America, Fontaine has thus referred to the want of a definite understanding as to the significance of these two names: "The two formations which are capable of misconception are the Wealden and Neocomian. By some, the Wealden formation is regarded as an independent group, forming the uppermost member of the Jurassic. Others regard it as a series of beds contemporaneous with a portion of the Lower Neocomian, formed in estuaries and marshes at the time when a portion of the typical Lower Neocomian, which is marine, was being depositer in the sea. The latter view is the one assumed in this [Fontaine's] Memoir." The term Neocomian is used by Fontaine as including the Urgonian and Aptian of D'Orbigny. He goes on to say: "When, then, reference is made to Neocomian plants,

\footnotetext{
1 II. B. Woodward, Geol. England and Wales, 1887, p. 40.

2 Topley, Weald, p. 1.

3 Potomac Flora, p. 331.
} 
fossils of the Wealden, Urgonian, and Aptian groups are included and not distinguished." 1

It will be well, therefore, at the outset to state definitely in what sense the term Wealden is used in the present Catalogue. In his Memoir on the Weald, Topley expresses the opinion that the Wealden and Purbeck strata should be classed together as one unbroken series. ${ }^{2}$ This and similar statements by various geologists might be quoted in support of a Purbeck-Wealden series, and, possibly, such would best represent the true stratigraphical relations of the two sets of beds. On the other hand we are not concerned here with any critical examination of the geological evidence, whether stratigraphical or palæontological; and for the present, at least, it will be more convenient to conform to the general usage of the term by English geologists, and include the Wealden beds in the Cretaceous system to the exclusion of the Purbeck.

In the Report of the British Committee to the International Geological Congress of 1888, the Reporters, Messrs. A. J. JukesBrowne and W. Topley, ${ }^{3}$ recommended a general classification of the Cretaceous system, in which the "Lower series" of the system is defined as comprising the Lower Greensand (Vectian), Weald Clay and Hastings Sands; the two latter being bracketed together as Neocomian.

In the correlation table of the Cretaceous system, giren by the same authors, the Purbeck beds are placed at the base in the South-Eastern area.

In Geikie's Text-book ${ }^{4}$ the usual classification is adopted, the Purbeck beds being regarded as the uppermost members of the Jurassic system.

In this connection it may be of interest to quote the riews recently put forward by Messrs. Parlow and Lamplugh in their Essay on the Speeton Clay. Their correlation of four zones

1 Potomac Flora, p. 332.

2 Weald, p. 321.

3 Cong. Géol. Int. App. B. Cretaceous, p. 77.

4 Text Book of Geology, 1893, p. 938. 
of this East Yorkshire formation with Wealden rocks of NorthWest Germany, England, and North France is expressed in tabular form as follows ${ }^{1}$ :-

FOUR ZONES OF SPEETON CLAY.

\begin{tabular}{|c|c|c|}
\hline \multicolumn{2}{|c|}{ N.W. Germanx. } & $\begin{array}{l}\text { S. ENGLAND AND } \\
\text { BoulogNe. }\end{array}$ \\
\hline \multicolumn{2}{|c|}{ Hils beds with Crioceras Emerici, etc., etc. } & Weald clay. \\
\hline \multicolumn{2}{|c|}{ IIils clay with Hoplites regalis, etc., ete. } & Hastings sands. \\
\hline $\begin{array}{l}\text { Upper Portlandian, brackish } \\
\text { or Purbeckian type } \\
\text { (Wealden of German geo- } \\
\text { logists). } \\
\\
\\
\end{array}$ & $\begin{array}{l}\text { Hils grit and con- } \\
\text { glomerate with } \\
\text { Belemnites lateralis, } \\
\text { etc. } \\
\text { rpulite } \\
\text { ünder Mergel }\end{array}$ & $\begin{array}{l}\text { Upper Portlandian, } \\
\text { brackish or Pur- } \\
\text { beckian type. }\end{array}$ \\
\hline
\end{tabular}

In another recent work, "Text Book of Comparative Geology," by Kayser (translated and edited by Lake), we find this extremely

WEALDEN.

\begin{tabular}{|c|c|c|}
\hline & Germany. & ENGLAND. \\
\hline Upper & Wälderthon ................. & Weald clay \\
\hline Middle & Deister sandstone .......... & Hastings sands . \\
\hline Lower & $\begin{array}{l}\text { Serpulite } \ldots . . . . . . . . . . . . . . \\
\text { Müunder MYergel ........ }\end{array}$ & Purbeck \\
\hline
\end{tabular}

simple talle in which the term Wealden is used in the wider sense. ${ }^{2}$

Haring thus defined the term Wealden as employed by some of the most recent writers, and stated the sense in which it is used

\footnotetext{
1 Arg. Speeton, pp. 200-201.

2 p. 288.
} 
in the present work, we will proceed to a general sketch of Wealden palæobotany.

In the early part of the present century the Wealden series of Southern England was examined by Mantell and Fitton, and it is mainly to their labours that we owe our earliest knowledge of the life of that period. Gideon Mantell in 1822 published a work on "The fossils of the South Downs, or Illustrations of the Geology of Sussex," and included those rocks to which the term Wealden is now applied under the so-called Greensand formations, which he subdivided thus ${ }^{1}$ :-

$$
\text { Greensand formation }\left\{\begin{array}{l}
\text { Iron Sand. } \\
\text { Tilgate beds. } \\
\text { Weald or Oak Tree clay. } \\
\text { Greensand. }
\end{array}\right.
$$

In the first of these subdivisions plant remains are recordect, but without any definite names, descriptions, or plates. The first figures and scientific names of Wealden plants are those contained in a paper contributed to the Transactions of the Geological Society in 1824. Two members of the Council, Messrs. Stokes and Webb, were appointed to describe certain fossils which had been forwarded to the Society by Mantell from Tilgate Forest; in the description of the plants "invaluable assistance" was received from Mr. Robert Brown. The following species are mentioned, with figures $^{2}$ :-

Clathraria anomala, S. and W. Carpolithus Mantelli, S. and W. = ? Equisetites Burchardt, Dunk. Hymenopteris psilotoides, $\mathrm{S}$. and $\mathrm{W} .=$ Onychiopsis Mantelli (Brong.).
Pecopteris reticulata, S. and $\mathrm{W}$. = Weichselia Mantelli (Brong.).

Endogenites erosa, S. and $\mathrm{W}_{0}=$ Tempskya Schimperi, Corda.

In 1833 Mantell's work appeared on "The Geology of the South-East of England," and in chapter xi. there is a "description of the organic remains of the Wealden, and particularly of those of the strata of Tilgate Forest." 3 The specific name of the genus Clathraria is changed from anomala to Lyelli, Hymenopteris psilotoides is spoken of as Sphenopteris Mantelli, Brong., Pecopteris

2 Trans. Geol. Soc. ser. ii. vol. i. 1824, p. 421.

3 p. 232. 
reliculata as Lonchopteris Ilantelli, Brong. In addition to these changes in nomenclature some additional species are recorded: Cycadites Brongniarti, Mant., Sphenopteris Sillimani, Mant.=? Onychiopsis IIantelli (Brong.), and S. Phillipsii=Ruffordia Göpperti (Dunk.), also Lycopodites?, Calamites, and Equisetum Lyelli, Mant.

The same author furnishes a list of Wealden plants in a communication to the Geological Society entitled "A tabular arrangement of the organic remains of the County of Sussex" ${ }^{1}$ but in this list there are no species added to those already mentioned. Three years later Fitton's important paper was published: "Observations on some of the Strata between the Chalk and the Oxford Oolite in the South-East of England." ${ }_{2}$ Under the heading Wealden, he includes Weald Clay, Hastings Sands, and Purbeck. New facts are brought forward with regard to the characteristic and problematical fossil Endogenites erosa, S. and W. $=$ Tempsiya Schimperi, Corda, and a new species of Sphenopteris, S. gracilis, Fitton ${ }^{3}=$ Sphenopteris Fittoni, sp. nог., is figured and briefly described; the occurrence of a Coniferous cone is also noted. Without attempting to follow each step in the progress of our knowledge of Wealden floras, we may pass at once to a more recent publication and notice what species are recorded. In Topley's Memoir, previously referred to, the following list of plants occurs ${ }^{4}$ :-

Araucarites (Zamiostrobus) Pippingfordensis, Ung.

Carpolithes Mantelli, Brong. =? Equisetites Burchardti, Dunk.

Clathraria Lyelli, S. and W. ${ }^{5}$

Endogenites erosa, S. and W. ${ }^{5}=$ Tempshya Sehimperi, Corda.

Equisetıtes (Equisetum) Lyellii, Mant. Lonchopteris Mantelli, Brong. = Weichselia Mantelli (Brong.).

Pterophyllum (Cycadites) Brongniarti, Mant.
Sphenopteris gracilis, Fitton $=$ Sphenopteris Fittoni, sp. nov.

S. Mantelli, Brong. = Onychiopsis Mantelli (Brong.).

S. Phillipsii, Mant. = Ruffordia Göpperti (Dunk.).

S. Sillimani, Mant. = ? Onychiopsis Mantelli (Brong.).

Thuytes (Cupressites) Kurrianus, Dunk.

Zamiostrobus (Zamia) crassus, Lind.

I Trans. Geol. Soc, ser. ii. vol. iii. 1835, p. 201.

2 Ibid. vol. iv. 1836, p. 103.

${ }^{3}$ p. 181, figs. 1 and 2, and Appendix A. p. 349.

+ Weald, p. 409.

"I latse sulstituted Stukes and Webb for Mantell as given by Topley as the authors of the species. 
In the later edition of Dixon's "Geology of Sussex," Carruthers has furnished a list of plunts of Wealden age; the following species being mentioned in addition to many of those included in Topley's list ${ }^{1}:-$

Laccopteris Göpperti, Schimp. = Matonidium Göpperti (Ett.).

Pecopteris Geinitzii, Dunk.
Equisetum Burchardti, Dunk. = Equisetites Burchardti, Dunk.

Pinites Dunkeri, Carr.

Cycadeostrobus, sp.

A brief sketch of the Wealden flora is given by $\mathrm{Bogle}^{2}$ in a paper on the "Wealden Strata of East Sussex," but no new species are added to the lists of plants recorded by previous writers.

The next communication on this subject, to which reference need be made, is a note by E. H. Peyton in $1883,{ }^{3}$ in which the following additional species are recorded from British Wealden strata:-Oleandridium (Teniopteris) Beyrichii, Schenk, Pecopteris Irurchisoni, Dunk., and Pterophyllum Schaumburgense (Dunk.); there is also a specimen mentioned which is considered to be probably Sphenopteris Göpperti, Dunk. = Ruffordia Gopperti (Dunk.).

In the later edition of Bristow's "Geology of the Isle of Wight," the following plants are mentioned as occurring in Wealden strata ${ }^{4}$ -

Pinites Carruthersi, Gardn.

P. Dunkeri, Mant.

$P$. valdensis, Gardn.

Bennettites Saxbyanus, Carr.

Carpotithes sertum $=$ impressions of

? Equisetites Yokoyamce, sp. nov.

Chara $?=C$. Knowltoni, sp. nov.

Clathraria Lyelli, S. and W.

Cycadeostrobus crassus, Carr.

C. elegans, Carr.

C. ovatus, Carr.

C. truncatus, Carr.
Cycadeostrobus turnidus, Carr.

C. Walkeri, Carr.

Endogenites erosa, S. and W. $=T_{c m p-}$ shya Schimperi, Corda.

Equisetites Burchardti, Dunk.

Fittonia squanata, Carr.

Lonchopteris Mantelli, Brong. = Weich selia Mantelli (Brong.).

Seeds.

Thuyites.

Zamia crassa? L. and H. (See Cyendeostrobus crassus, Carr.)

1 Geol. Sussex, 1878, p. 279.

2 Trans. Nat. Hist. Soc. Eastbourne, May 20, 1881. (I am indebted to the Rev. H. G. Jameson, of Eastbourne, for a short abstract of this paper.)

3 Quart. Journ. Geol. Soc. vol. xxxix. 1883, Proc. p. 3.

4 Geol. I. Wight, 1889, p. 258. 
In aldition to the plants already enumerated, the following Gymnosperms must be noted from the papers of Carruthers, Starkie Gardner, and others :-

Pinites Mrantelli, Carr. ${ }^{1}$

P. patens, Carr.

? P. Fittoni, Carr. (This is described

by Carruthers as labelled from Pur- beck, but the species is quoted on another page of the same paper as a Wealden Conifer.)

In the Report on Mesozoic and Tertiary Gymnosperms presented to the British Association in 1886, ${ }^{2}$ there is the following statement, which has not been disprored by subsequent discoreries. After speaking of some fossil plants previously mentioned by Mantell and compared to Dracena, the writer of the Report continues - "No other trace has been found of any more highly organized plants than Ferns or Gymnosperms, and this, when we remember that Monocotyledons were undoubtedly in existence, is a fact that should be of great significance to speculative geologists. The sediments must represent the deposits of a drainage system of a large area, for they are of rast extent and thickness, varied in character, and abounding in remains of trunks and stems, fruits and foliage of plants. In them, therefore, if anywhere, we might reasonably expect to find, at least, the trace of reed and rush, but the swamps seem to hare been tenanted only by Equisetums and Ferns, and the forests mainly by Cycads and Conifers." 3

This is especially noteworthy, as Angiosperms have been recorded in floras, agreeing in their general facies with the Euglish Wealden, from North America and Portugal.

The great majority of the specimens described in the present rolume have been obtained by Mrr. Rufford from the Wealden rocks in the neighbourhood of Hastings. I am indebted to him for the following diagrammatic section and bricf description of the strata from which the material was obtained.

1 Geol. Mag. rol. iii. 1886, p. 543.

2 p. 243.

3 This statement has reference to British fossils only. 
INTRODUCTION.

"c. Wadhurst Clay." Consisting of dark-blue shales and clays, intercalated with thin slabs of sandstone, also sand-rock, with 'blue stone' at base.

"b. Ashdown Sands. Thick beds of sandstone, divided by thin layers of shales and clays.

"a. Fairlight Clays. Clays and shales predominating, but with some beds of sandstone and ironstone; these latter yielding, very locally, Ferns, Cycads and Conifers.

"NoтE.-The general course of the ancient Wealden River, as evidenced by the ripple-marks (which would naturally be found parallel to the stream), and also by the trend of scattered remains, such as the bones of individual animals, trunks of trees, and other débris, appears to have taken a direction in the neighbourhood of Hastings from N.E. to S.W. Consequently the coast section would be obliquely across the bed of the river, and this fact may account for the very limited extent of outeropping fossiliferous beds."

I See also Topley, Weald, p. 46.

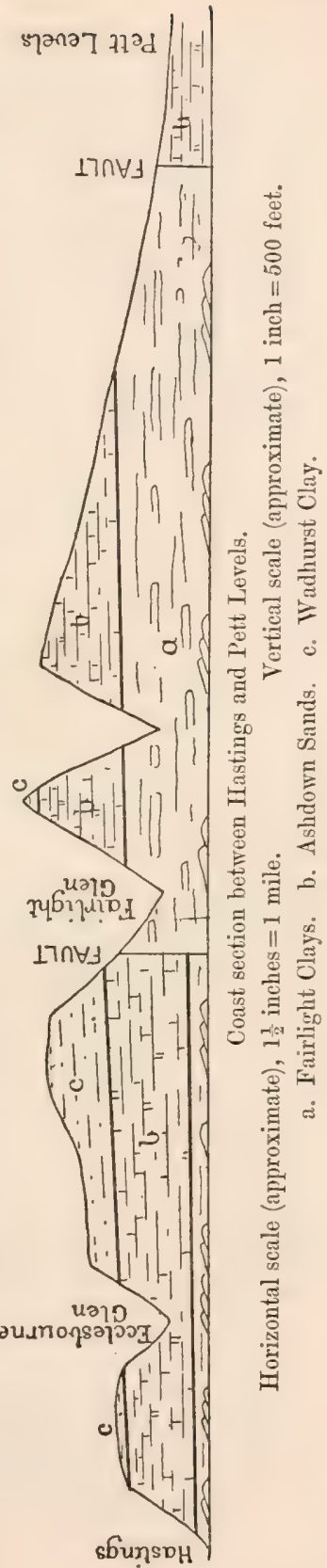




\section{FRANCE.}

Three species of Wealden plants are mentioned by Brongniart from Beaurais ${ }^{1}$ :-

Lonchopteris Mantelli, Brong. = Weichselia Mantelli (Brong.).

Pachypteris gracilis, Brong. = Sphenopteris Fitloni, sp. nov.

Brachyphyllum Gravesii, Brong.

De Lapparent, in his "Traité de Geologie," 2 refers to the development of fresh-water infra-Cretaceous rocks south of Beaurais in the Pays de Bray, and notes the occurrence of the common English fossil Weichselia IIantelli (Brong.). ${ }^{3}$

\section{GERMANY.}

Dunker's well-known Monograph, ${ }^{4}$ which appeared in 1846 , deals exhausticely with the fresh-water formation of Northern Germany, previously correlated by Hoffman with the English Wealden. These rocks are comprised in a stretch of country between Helmstiidt and Bentheim, and are usually subdivided into two members, the lower consisting of sandstones, etc., and the upper of clay beds; to the former the term Wealden or Deister Sandstone (= Hastings Sands of English geologists) is applied, and to the latter Weald Clay. The flora of these North German beds is obriously of the same facies as the Wealden of England, and no doubt of the same geological age. It should be noticed, however, that in Parlow and Lamplugh's Monograph, ${ }^{5}$ to which reference has already been made, it is stated that the beds in Germany spoken of as Wealden have little in common with the typical Wealden of England.

The next contribution to which attention needs to be called is one from Ettingshausen in 1852 on the doubtful fossil Palcoxyris, Brong., which is described at some length from the Deister beds under the name of Palcobromelia Jugleri, Ett. ${ }^{6}$ The mention of Palcoxyris in this introductory sketch is not intended to imply

1 Tableau, p. 107.

2 1885, p. 1042 ; see also Passy, Descript. Géol. Seine-inf. p. 194.

3 Siapurtit has recently recorded auother species from the Lower Wrealden of Boulonne, Sphenopteris Delgadoi, ? Sap. $=$ S. Fittoni, sp. nov. Rer. gen. bot. vol. v. p. 365, 1893, pl. iv. fig. $5 . \quad 4$ Wealdenbildung. $\quad{ }^{5}$ p. 189.

${ }^{6}$ Abh. k.-k. geol. Reichs. vol. i. 1852, Abth. iii. p. 1. 
that it should necessarily be included in the list of Wealden plants; very possibly, as Zeiller and Renault have shown, this puzzle to palæobotanists may find its proper place among fossil animals. ${ }^{1}$

Schenk's important contributions, ${ }^{2}$ while correcting the earlier work of Dunker and others, supply much additional information as to the flora of the German Wealden. Several of Dunker's species are found by Schenk to have no claim to stand as such, but are shown by the more perfect material collected since 1846 to be fragments of different portions of one and the same species.

Following the two papers by Schenk we have a useful Monograph by Struckmann, ${ }^{3}$ in which the following list of Wealden plants is given; and this may be taken to represent the species recorded from German Wealden rocks up to 1880 .

Fucoiditece?

Equisetum Burchardti, Dunk. = Equisetites Burchardti, Dunk.

Sphenopteris Mantelli, Brong. = Onychiopsis Mantelli (Brong.).

S. Göpperti, Dunk. = Rutfordia Göpperti (Dunk.).

S. delicatissima, Schenk.

Lomatopteris Schimperi, Schenk.

Baiera pluriparita, Schimp.

Pecopteris Dunkeri, Schimp. =Cladophlebis Dunkeri (Schimp.).

P. Murchisoni, Dunk.

P. Geinitzii, Dunk. ${ }^{4}$ Schenk's figure $=$ Sphenopteris Fittoni, sp. nov.

Alethopteris Browniana (Dunk.) = Cladophlebis Browniana (Dunk.). A. Huttoni (Dunk.). A. cycadina, Schenk.

Matonidium (Laccopteris) Göpperti (Schimp.).
Laccopteris Dunkeri, Schenk $=$ Microdictyon Dunkeri (Schenk).

Sagenopteris MLantelli (Dunk.).

Hausmannia dichotoma, Dunk.

Marsilidium speciosum, Schenk.

Jeanpaulia Brauniana, Dunk.

Tempskya Schimperi, Corda.

Protopteris Witteana, Schenk.

Clathraria Lyelli, S. and W. ${ }^{5}$

Cycadites Roemeri, Schenk.

Anomozamites Schaumburgense(Dunk.).

Pterophyllum Lyellianum, Dunk.

Dioonites Dunkerianus (Göpp.).

D. Göppertianus (Dunk.).

Pachyphyllum curvifolium (Dunk.).

$P$. crassifolium, Schenk.

Abietites Linkii (A. Rmr.).

Sphenolepis Sternbergiana (Dunk.).

S. Kurriana (Dunk.).

Spirangium Jugleri (Ett.).

1 Compt. Rend. vol. cvii. 1888, p. 1022.

2 Palæontographica, vol. xix. 1871, and vol, xxiii. 1875.

3 Weald. Hannover, p. 44.

4 The existence of Dunker's Wealden species, P. Geinitzii, seems to have been orerlooked by Gutbier and others, who make use of the same name for a Permian fern of a different character. e.g. See Sterzel, Flor. Roth. Plauenschen Grunde, Abh. k. Sachs. Ges. Wiss. math. phys. Cl. vol. xix. p. 120, 1893.

5 Mantell is given by Struckmann as the author of this species. 
In a paper by Hosius and Von der Marek, published in the Palæontographica for 1879-1880, a number of plants are figured and described from the Westphalian Chalk formation; the following species are mentioned from the Lower Gault and Neocomian ${ }^{1}:-$

Lonchopteris recentior, Schenk $=$ Weichselia ILantelli (Brong.).

Clathraria galtiana, Hos. and V.d. M. Megalozamia falciformis, Hos. and V. d. M.

Protopteris punctata (Sternb.).

Weichselia Ludovice, Stiehler $=W$. IFantelli (Brong.).

Laccopteris Dunkeri, Schenk = Microdietyon Dunkeri (Schenk).

Sagenopteris Neocomiensis, Hos. and V. d. M.
Pterophyllum Germaria, E. v. Otto.

P. blechniforme, Hos, and V. d. M. $P$. Saxonicum, Reich.

Dioonites abietinus, Miguel.

Podozamates aqualis, Miguel.

Zamites iburgensis, Hos. and T. d. M. Z. nervosus, Schenk.

Abietites Linkii, Roem.

Sphenolepis Sternbergiana, Schenk.

S. Kurriana? Schenk.

Pitcairnia primava, Hos. and V.d. M.

In a later communication from the same authors Pinus Quenstedti, Heer, is added to the list of Neocomian plants from Westphalia. ${ }^{2}$

A number of distinctly Wealden plants has been recorded from strata in the neighbourhood of Quedlinburg, on the northern side of the Hartz Mountains; these beds are spoken of as Lower Quadersandstone and "Hilssandstein." The following species are given by Schulze ${ }^{3}:-$

Alethopteris cycadina, Schenk.

A. revoluta.

Matonidium Göpperti, Schenk.

Gleicheria, cf. rotula, $\mathrm{Hr}$.

$G$. cf. giesekiana, Hr.

Cf. Lonchopteris Mantelli, Brong.= Wichselia Mantelli (Brong.).
Pteridophyllum fastigiatum, Schulze. Zamites, sp.

Cf. Sequoia falcifolia, Roemer, sp. = Sphenolepis Sternbergiana, Schenk. Sphenolepis imbricata, Roemer, sp. $=$ S. Kurriana, Schenk.

1 Palæontographica, vol. xxvi. 1880, pp. 201 et seq.

2 Ibid. vol. xxxi. 1885, p. 231.

3 Flor. subhercyn. Kreid. pp. 10 et seq. 
In addition to these there are three species recorded from Langenberg near Quedlinburg ${ }^{1}:-$

Weichselia Ludovica, Stiehler $=W$. AFantelli (Brong) .

Pterophyllum Ernestine, Stiehler.

Pandanus Similda, Stiehler.

In a recent communication from Struckmann ${ }^{2}$ on the strata between the "Hilsthon" and Wealden of North Germany, it is pointed out that in England the brackish water-deposits at the end of the Jurassic period seem to have continued for a longer time than in North Germany; and this author suggests that the Wealden should be regarded not as a distinct formation, but as a facies, consisting of brackish water-deposits at the close of the Jurassic period, and which, in some places, extended to the Chalk.

\section{AUSTRIA.}

Ettingshausen in 1852 described a number of fossil plants from Zöbing and a few other localities, from beds considered to be of Wealden age; many of the species being identical with Wealden plants of Northern Germany. The following species are recorded from these plant-bearing beds ${ }^{3}:-$

Confervites setaceus, Ett.

Sargassites Partschii, Ett.

Spharococites chondriaformis, Ett.

Equisetites Burchardti, Dunk.

Cyclopteris squamata, Ett.

C. Mantelli, Dunk. = ? Sagenopteris

IIantelli (Dunk.).

Sphenopteris Mantelli, Brong.=Onychiopsis Mantelli (Brong.).

Alethopteris recentior, Ett. = ? Weichselia Mantelli (Brong.).
Taniopteris Zöbingiana, Ett. = ? Fragment of Neuropteris.

Cycadites Brongniarti, Roem.

Pterophyllum Buchianum, Ett.

P. nervosum, Ett.

Culmites priscus, Ett.

Thuites Hoheneggeri, Ett.

Araucarites Dunkeri, Ett.

A. curvifolius, Ett.

Carpolithes Lindleyanus, Dunk.

C. rostellatus, Ett.

In 1871 Schenk discusses the plants and geologic age of the Wernsdorfer beds at some length; from an examination of the flora he concludes that these Carpathian rocks are nearer in age

1 Flor. subhercyn. Kreid. p. 14.

2 Jahrb. k. preuss. geol. Landesanst, 1889, p. 54.

3 Abh. k.-k. geol. Reichs, vol. i. Abth. iii. No. 2, 1852, p. 1. 
to the Jura and Wealden than to the Chalk period. The following additions are made to the species already included among the plants from Ettingshausen's Wealden localities ${ }^{1}$ :-

Chondrites furcillatus, Roem.

Baiera cretosa, Sch.

Cycadopteris Dunkieri, Sch.

Cyeadites Heerii, Sch.

Podozamites Zittelii, Sch.
P. Hoheneggeri, Sch.

P. obovatus, Sch.

Zamites Göpperti, Sch., and four other species.

Widdringtonites gracilis, Heer?

In Velenorsky's contributions to Mesozoic botany we hare certain species recorded from Lower Cretaceous rocks in Bohemia which point to a close agreement in facies with the North German and English Wealden. These beds are classed by Velenorsk'y as Cenomanian." Among the "Ferns" from Peruc and other localities the following species occur, which are identical with or closely allied to typical Wealden forms:-

Thyrsopteris capsulifera, Vel.

Laccopteris Dunkeri, Schenk = Microdictyon Dunkeri (Schenk).

Pteris frigida, Heer.
P. Albertini (Dunk.) $=$ ? Cladophlebis Albertsii (Dunk.).

Jeanpaulia carinata, Vel.

Dicksonia punctata (Sternb.).

Tempshya va ians (Corda).

Among the Gymnosperms from the same beds there are certain forms which closely resemble Wealden species ${ }^{3}-e . g$. :-

Thinnfeldia variabilis, Vel. =? Sagenopteris Mantelli (Dunk.).

Nitssonia Bohesnica, Vel.

Sequoia Reichenbachi, Heer.
Cunninghamites elegans, Heer.

Pinus Quenstedti, Heer.

Eolirion primigenium, Sch.

\section{PORTUGAL.}

In his "Contributions à la flore fossil du Portugal" Heer has given descriptions and illustrations of the following species from two localities-Almargem and Valle de Lobos; these floras are considered by him to be in "intimate relation with the Wealden flora."

I Palæontographica, vol. xix. 1871, p. 23.

2 Abh. k. böhm. Ges. Wiss. vii. Folg. Band ii. 1888.

${ }^{3}$ Gymn. böhm. Kreid.

4 Secc. Trab. Geol. Portugal, 1881, p. vi. 
Tanidium lusitanicum, Hr.

Sphenopteris Mantelli, Brong.=Onychiopsis Mantelli (Brong.).

S. Gomesiana, Hr.

S. plurinervia, $\mathrm{Hr}$.

S. valdensis, Hr. (in part) $=$ Onych $i$ opsis Mantelli (Brong.).

S. angustilobre, $\mathrm{Hr}$.

S. lupulina, $\mathrm{Hr}$.

Pecopteris Dunkeri, Schimp. = Cladophlebis Dunkeri (Schimp.).

P. Choffatiana, Hr.

Laccopteris pulchella, $\mathrm{Hr}$.

ILatonidium Göpperti, Ett., sp.
Ctenidium integerrimum, $\mathrm{Hr}$.

C. dentatım, $\mathrm{Hr}$.

Czekanowskia nervosa, Hr.

Sequoia lusitanica, $\mathrm{Hr}$.

Sphenolepidium Sternbergianum,

Dunk., sp.

S. Kurrianum, Dunk., sp.

S. debile, Hr.

Brachyphyllum obesum, Hr.

$B$. corallinum, Hr.

Frenelopsis occidentalis, $\mathrm{Hr}$.

Bambusium latifolium, Hr.

Caulinites atavinus, $\mathrm{Hr}$.

INore recently Saporta has published a note in the Comptes Rendus for $1891,{ }^{1}$ in which he mentions some interesting species of fossil plants discovered at Cercal, between Cenomanian and "Neojurassic" beds. Among the ferns he draws attention to Sphenopteris Mantelli, Brong., S. plurinervia, Hr., S. valdensis, $\mathrm{Hr}$, and S. angustiloba, Hr.; there are also two species of Hepatice recorded, and two or three Lycopodiaceous plants, with a remarkable new species, Isoetopsis Choffati, referred to the Isoetacere. Brachyphyllum, Sphenolepidium and Frenelopsis are quoted as Coniferous genera.

The most important fossils are, however, certain species which he considers to be Angiosperms, and especially Dicotyledons. Poacites, Brong., Zosteris, Brong., and Delgadoa, Sap., are placed among the Monocotyledons, with Protolemna and Protorrhipsis, Andr., as representatives of the oldest known Dicotyledons.

\section{BELGIUM.}

Under the head of Wealden plants we must include the following species of Cycads and Conifers described by Coemans from Baume ${ }^{2}$ :-

1 Compt. Rend. vol. cxiii. 1891, p. 249. See also Rev. gen, bot. vol, v. 1893.

2 Mém. Ac. R. Belg. vol. xxxvi. 1867, p. 82. 
Cycadites Schachti, Coem.

Pinus Omalii, Coem.

P. Briarti, Coem.

P. (Cedrus Corneti ?), Coem.

P. Andrai, Coem.

With these species from St. Vaast there should be mentioned the following, which were discorered in the Colliery of Bernissart, in the same beds which have yielded Iguanodon remains in such extraordinary abundance. The species included in the list are given by Dupont in a paper published in 1878, Saporta being responsible for the names ${ }^{1}:-$

Lonchopteris . Muntelli, Brong. = Weichselia ILantelli (Brong.).

Pecopteris polymorpha, [hunk, = Cladophlebis Dunkeri (Schimp.).

$P$. Conybeari, Dunk. = Matonidium Göpperti (Ett.).

Alethopteris elegans, Göpp. =M. Göp. perti (Ett.).

We hare the late Prof. Newberry's testimon ${ }^{2}$ that no trace of any Angiospermous species occurs among the plants found with the Iguanodon remains at Bernissart.

Dr. Bommer, of Brussels, is at present engaged upon the examination of certain Wealden plants recently collected in the neighbourhood of the same locality from which Coeman's specimens were obtained. ${ }^{3}$

\section{RUSSIA.}

In the Bull. Soc. nat. Moscou for 1844, Anerbach figures and gives brief descriptions of some fossil plants from Sandstone strata in the province of Moscow. ${ }^{4}$ There is, howerer, no discussion in his paper as to the age of the rocks, but among the figures a species is represented which has a striking resemblance to Weichselia (Lonchopteris) Mantelli (Brong.). Turning to Murchison's "Geology of Russia" (1845), we find the statement that no Wralilen rocks occur cither in Russia or Poland. ${ }^{5}$ The

1 Bull. Ac. R. Belg. sér. ii. 1878, p. 396.

2 Amer. Journ. vol. xli. 1891, p. 194.

3 Letter from Dr. Bommer, Nov. 1893.

4 Vol. xvii. 1844, 1, p. 145 , pl. v.

5 Geol. Russia, rol. i. p. 260. 
geologic age of the Klin Sandstones from which Auerbach's plants were obtained has given rise to considerable discussion; according to Eichwald ${ }^{1}$ the so-called "Klin'sche Sandstein" must be regarded as homotaxial with the Quadersandstein; on the other hand Trautschold, ${ }^{2}$ who has described the plants from these strata, insists on the close agreement of the flora with that of the North German Wealden. He supports his own opinion as to the age of the Klin beds against that of Eichwald, by quoting Dunker's views, based on an examination of the plants. The following is a list of the species given in Trautschold's Monograph; he points out the admixture of Jurassic and Cretaceous forms, and recognizes that some of the species undoubtedly give a Wealden facies to the flora.

Calamites, sp.

Equisetites, sp.

Odontopteris dubia, Traut.

Sphenopteris Auerbachi, Traut. $=R u f$ -

fordia Göpperti (Dunk.).

Reussia pectinata, Göpp.

Asplenites desertorum, Traut.

A. $K$ linensis, Traut. (in part) $=$ Weich -

selia LIantelli (Brong.).

Alethopteris Reichiana (Brong.).

A. metrica, Traut.

Pecopteris Whitbyensis, Brong. = Cladophlebis Albertsii (Dunk.).

P. Althausi, Dunk. $=$ Matonidium Göpperti (Ett.).
Pecopteris nigrescens, Traut.

P. decipiens, Traut. = Microdictyon Dunkeri (Schenk).

$P$. pachycarpa, Traut.

P. explanata, Traut. $=$ ? Matonidium Göpperti (Ett.).

Polypodites Mantelli, Göpp. $=$ Weich selia Mantelli (Brong.).

Glossopteris solitaria, Traut.

Cycadites acinaciformis, Traut.

Thuytes ecarinatus, Traut.

Araucariles hamatus, Traut.

Pinus elliptica, Traut.

Auerbachia echinata, Traut.

Phyllites regularis, Traut.

Sereral of these determinations have been justly called into question by Schenk. ${ }^{3}$

These plant beds of Klin, Tatarowo, etc., are placed by Paviow and Lamplugh on the same hurizon as the Upper Portland (brackish or Purbeckian type) and the Hils Conglomerate.* Carruthers ${ }^{5}$ has expressed the opinion, in a footnote to a paper in the eighth rolume of the Geological Magazine (1871), that the facies of the Klin flora is Cretaceous in character.

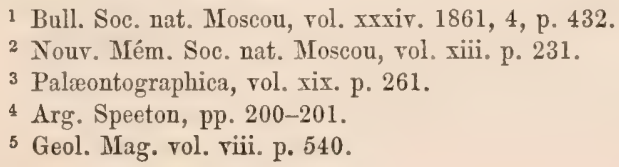




\section{GREENLAND.}

Without quoting the Kome beds of Greenland as undoubtedly arreeing in the character of their flora with the Wealden of England and North Germany, it must be noted that Heer has insisted on the fact that there are several features in common between them and the rocks of Wealden age in more southern latitudes.

This well-known flora ${ }^{1}$ has been collected from several localities in the Noursoak Peninsula on the west coast of Greenland; it is characterized, among Greenland fossil floras, by the almost total absence of Dicotyledons. We shall be in a better position to examine the general characters of the Kome plants, and take note of such species of distinctly Wealden type as are represented in these northern latitudes, when we have completed the description of the English Wealden flora.

Heer points out, that in spite of the small number of species in common, there are enough to form a connecting link between the Kome flora and those of the Wernstorfer beds and typical Wealden districts ${ }^{2}$ certain nearly allied species are quoted in support of this assertion. Johnstrup, in the French resume at the end of the fifth volume of the Meddelelser om Grönland, speaks of the Kome flora as undoubtedly Urgonian in age. ${ }^{3}$ The same flora is referred to by Dawson in a recent number of "Nature," 4 as probably corresponding to the Kootanie of Canada and the Wealden of England.

\section{AMERICA.}

An exceedingly important work has recently been completed by Prof. Fontaine, in which an abundant and varied flora is described from the Potomac beds of North America. The term "Potomac"

1 Fl. foss. Aret. vols, iii. vi. and vii. See also Meddel. Grönland, vol. v. 1853. For list of fossils see Fl. foss. Arct. vol. vii. pp. 173 et seq.

2 Heer, loc. cit. vol. vii. p. 157.

3 Meddel. Grönland, loc. cit. p. 227.

$\$$ Vol. xlvii. 1893, p. 557. 
was first used by MCGee on account of the development of typical rocks of this series along the course of the Potomac river. Most of the plants from these strata were collected from Virginia, a few also from Maryland. Fontaine considers it very probable that the Potomac beds were laid down under conditions very similar to those characteristic of the European Wealden sediments; ${ }^{1}$ he shows, too, that there is an important floral element in the Potomac regetation which finds its nearest representative in the Wealden rocks of Europe. The same author expresses astonishment at the unusually large number of new species which his researches have brought to light in the Potomac flora. ${ }^{2}$ Many of the specimens which he has figured are without doubt new forms; but, in looking carefully orer the numerous illustrations, it is difficult, in some cases, to appreciate the minute differences which are pointed to as evidence of specific distinctions, and the impression is left that the list of new species is perhaps rather longer than it need have been. Be this as it may, the flora is of exceptional interest, and throws fresh light on the difficult problem of the evolution of Dicotyledons.

The following species are quoted by Fontaine as identical with, or closely allied to, European Wealden plants ${ }^{3}$ :-

Equisetru Iyelli, Mant. = Equisetites Lyelli, Mant.

E. virginicum, Font.

Cladophlebis constricta, Font.

C. falcata, Font.

C. acuta, Font.

C. oblongifolia, Font.

C. brevipennis, Font.

Pecopteris strictinervis, Font.

$P$. constricta, Font.

P. Browniana, Dunk.

Sphenopteris Mantelli, Brong.=Onychiopsis Mantelli (Brong.).
Aspidium Dunteri, Schimp. $=C l u d o$. phlebis Dunkeri (Schimp.).

Asplenium dubium, Font.

Thyrsopteris rarinervis, Font. $=$ Onychiopsis elongata (Geyl.).

$T$. densifolia, Font.

Dioonites Buchianus, Schimp.

Dioonites Buchianus, var. angustifolius, Font.

Tysonia Marylandica, Font.

Sphenolepidium virginicum, Font.

S. Kurrianum, Heer.

S. Stembergianum (Dunk.), Heer.

The flora, as a whole, Fontaine considers to range from the

1 Potomac Flora, p. 62.

2 Ibid. p. 334.

${ }^{3}$ pp. 350 et seq. 
Tealden, through the Urgonian, and probably including some Cenomanian forms.

Lester Ward has discussed the geologic age of the Potomac flora in a paper published before the appearance of Fontaine's Monograph; in a table intended to show the floral elements of this flora he demonstrates the predominance of the Wealden ficcies. ${ }^{1}$ The eridence of the plants is obviously in farour of assigning these Eastern American strata to the Wealden period, but Ward points to the rertebrate fossils as indicative of a Jurassic age, thus furnishing another example of an apparent discrepancy between plants and animals as indices of geological position. He does not wish to argue for the Jurassic age of the Potomac flora, but remarks that " the most it is intended to claim is that, if stratigraphical relations and the animal remains shall require its reference to the Jurassic, the plants do not present any serious obstacle to such reference." 2

Knowlton, ${ }^{3}$ in his paper on the fossil wood and lignite of the Potomac beds, has also pointed out this divergence of opinion between palæobotanists and palæozoologists.

Newberry, ${ }^{4}$ in view of the large number of Angiosperms in this flora, expressed himself in favour of a higher rather than a lower horizon than the Wealden. The same author, in the paper referred to, gives an account of the flora of the Great Falls Coalfield, Montana; this coal-basin lies on the northern slope of the Belt and Highwood Mountains, subordinate folds of the Rocky ILountain system. After speaking of Fontaine's determination of the Great Falls plants, to whom they had been submitted for examination, Newberry concludes that these identifications " prove conclusirely the general identity of the geological horizons of the Potomac group, the Great Falls group, the Kootanie group of Cinadia, and the Kome group of Greenland, and confirm the riew arrocated by Prof. Fontaine and myself that the Potomac group

1 Amer. Journ. ser. iii. vol. xxxri. 1888, p. 126.

2 Ibid. p. 131.

3 Bull. U.S. Geol. Surv. No. 56, 1889, p. 38.

- Amer. Journ. vol. xli. 1891, p. 194. 
is Lower Cretaceous and not Jurassic ; " and, in another place, he adds: "With equal certainty we can assert that the Potomac, the Kootanie, and the Kome groups represent perhaps distinct but closely related epochs of the Neocomian or Lower Cretaceous of the old World." 2

The following list shows the close resemblance between this Great Falls flora and the Old World Wealden:-

Thyrsopteris rarinervis, Font.

A plant near to Podozamites distantinervis, Font.

Cladophlebis paria, Font. Sequoia Reichenbachi, Heer.

Pecopteris Browniana, Dunk. =Cladophlebis Brouniana (Dunk.).

Aspidium Fredericksburgense, Font.

Sphenolepidium virginicum, Font.

A plant allied to Thyrspteris brevifolia, Font.

A plant near to Cladophlebis distans, Font.

Thyrsopteris insignis, Font.

Carpolithus virginiensis, Font.
A plant near to Cycadiospermum rotundatum, Font.

Pecopteris microdonta, Font.

Thyrsopteris brevipennis, Font.

A plant near to Cladophlebis constricta, Font.

Chiropteris Williamsii, Newb.

C. Spatulata, Newb.

Zamites apertus, Newb.

Baiera brevifolia, Newb.

Cladophlebis angustifolia, Newb.

Sequoia acutifolia, Newb.

Podozamites nervosa, Newb.

Oleandra arctica, Heer.

In a more recent paper Fontaine ${ }^{3}$ fully endorses the opinious expressed by Newberry as to the age of the Great Falls group of Montana, and records the following additional species from this flora:-

Equisetum Lyelli?, Mant.

Aspidium Montanense, Font.

A. monocarpum, Font.

A. angustipinnatum, Font., var. Montanense, Font.

Pecopteris Montanensis, Font.

P. Browniana,? Dunk.

Cladophlebis heterophylla, Font.

Osmunda dicksonioides, Font.
Thyrsopteris mieroloba, ? var. alata, Font.

T. rarinervis, Font.

Sequoia ambigua, ? Heer.

S. rigida, Heer.

Sphenolepidium virginicum, Font.

Taxodium (Glyptostrobus) ramosium, Font.

Zamites Montanensis, Font.

One of the new species in the abore list, Aspidium Montanense, seems to come very near to Cladophlebis Dunkeri (Schimp.). ('f.

1 Amer. Journ. vol. xli. 1891, p. 193.

2 Ibid. p. 195.

3 Proc. U.S. Nat. Mus, vol. xv. 1892, p. 488. 
Fontaine's figures, pl. lxxxii. and Pl. VII. Fig. 3 of the present Catalogue.

In a posthumous work by Lesquereux on the Flora of the Diknta group, edited by Knowlton, we find this American flora correlated with that of the Harz Quadersandstein, also with the floras of Nielerschöna and Quedlinburg. ${ }^{1}$ Reference has been made to these German floras because certain of their floral elements show a close relationship to members of the typical Wealden regetation; in the Dakota flora there seems to be hardly the same reason for comparison with the Wealden floras of Southern England and Northern Germany. The two species Gleichenia Nordenstiöldi, Heer, and Sequoia Reichenbachi, Gein., are common to the Dakota and Potomac floras; sereral species also oceur in the Kotanie flora, in the Neocomian of Westphalia and the Urgonian of Kome, but we do not find a distinct Wealden facies in the Cenomanian Dakota flora. ${ }^{2}$

For a critical account of the Cretaceous rocks of America reference should be made to the Cretaceous Correlation papers h) C. A. White, which hare appeared in a recent number of the United States Geological Survey Bulletins. ${ }^{3}$ The Potomac furmation is provisionally assigned to the base of the Cretaceous system, but stress is laid on the difficulty of arriring at any very definite conclusions as to the real age of this widespread deposit. It is pointed out that a large proportion of the plant remains figured by Fontaine from Tirginia were found in rounded and lenticular masses of indurated clay imbedded in the Sandstone or Arkose deposit: "One is therefore disposed," says White, "to inquire whether the plants may not represent a somewhat older deposit than is that part of the Potomac formation in which they are found." 4

No attempt is made in this Correlation paper to correlate the American dirisions of the Cretaceous system with their European

1 Dakota Flora, p. 20.

2 Ibid. pp. 222 et seq. "Table of distribution."

3 Bull. U.S. Geol. Surv. No. 82, 1891.

1 Ibid. p. 90. 
equiralents, because it is believed "that much more extensive studies of these formations ought to be made before any such correlation can be satisfactorily established."1

Referring to Newberry's discosery of Potomac species in the Kootanie beds of the Great Falls of Missouri river in Montana, White points out that, although some of the plants may be identical, it is certain the waters in which the two formations were deposited were geographically widely separated. ${ }^{2}$

\section{CANADA.}

In a table of correlation given by $\mathrm{Newberry}^{3}$ in a paper on the Cretaceous floras of North America, he places the Kontanie plantbearing beds of Canada on the same horizon with the European Wealden. Dawson ${ }^{4}$ considers these beds as representatives of the Urgonian or Teocomian series; he compares them to the Kome beds of Greenland. There are, however, no typical Wealden plants included in Dawson's list; a comparison is made between Salisburia (Ginligo) lepida, Heer, and certain leaves described by Dunker from the Deister Wealden, but no reference is given to indicate what particular leaves are referred to. The only plantbeds of America with which Dawson compares the Kootanie fossils are some in Maryland, in which Tyson discovered large Cycadean stems and which he referred to a Wealden age. ${ }^{5}$

\section{JAPAN.}

In 1877 Geyler ${ }^{6}$ described and figured twelve species of "Jurassic" plants from the valley of the Tetorigawa in Kuga,

1 Bull. U.S. Geol. Surt. No. 82, p. 208.

2 Ibid. p. 252 .

3 Trans. N. York. Ac. Sci. vol. v. 1885-86, p. 135.

- Trans. R. Soc. Canada, vol. iii. 1885.

5 Ibid. p. 18.

6 Palæontographica, vol. xxir. p. 221. 
and in comparing this flora with those of other countries a resemblance is pointed out between the Japanese plants and some species described by Heer from Siberia and Spitzbergen.

Nine years later Matajoro Yokoyama' contributed a paper on the Jurassic plants of Kaga, Hida and Echizen, and adds a list of species from these localities. At a later date ${ }^{2}$ he gives a much fuller account of this exceedingly interesting flora; and a detailed comparison is instituted with floras of other countries, the Jurassic floras of Siberia, Spitzbergen, the Yorkshire coast, Russia, China, Inclia and Australia, also with the Wealden of Europe and the infra-Liassic of Tongking.

A reference is made by Lester Ward ${ }^{3}$ in his "Geographical Distribution of Fossil Plants" to Yokoyama's earlier paper, and the suggestion offered that possibly these Japanese plants may prove to be of Lower Cretaceous age, and that the reference by Godfrey of the Kiushin leaf-beds to a Cretaceous horizon may have been correct." The eridence afforded by the ferns is certainly in favour of Ward's suggestion.

In 1890 Nathorst $^{5}$ made an important contribution to our knowledge of Japanese palæobotany. The plants from some of the localities are compared principally to Wealden species, and from other places there seems to be a mixture of Jurassic with Wealden and Urgonian species.

Although the titles to the papers of Geyler and Yokojama lead us to expect floras of distinctly Jurassic facies, we shall have occasion to point out in the description of certain English Wealden species a striking similarity, if not specific identity, between them and some of the Japanese plants.

The following list includes the plants mentioned by Yokoyama and Nathorst:-

1 Bull. Geol. Soc. Japan, pt. B, vol. i. No. 1, 1886.

2 Journ. Coll. Sci. Japan, vol. iii. 1890, p. 1.

3 U.S. Geol. Surv. Ann. Rep. No. 8, p. 789.

4 Quart. Journ. Geol. Soc. vol. xxxiv. 1878, p. 546.

5 Denksch. k. Ak. Wiss. math.-nat. Cl. vol. lvii. 1890, p. 43. 
Thyrsopteris Mrurrayana, Brong.

T. prisca, Eich.

T. kagensis, Yok.

Dicksonia gracilis, Hr.

D. acutiloba, Hr., var.

D. cf. Glehniana, Hr.

D. nephrocarpa, Bunb.

Onychiopsis elongata (Geyl.).

Adiantites Heerianus, Yok.

A. Kochibeanus, Yok.

A. lanceus, Yok.

Asplenium Whitbiense, Brong.

A. argutulum, Hr.

A. distans, $\mathrm{Hr}$.

Sphenopteris, sp. = Ruffurdia Göpperti

(Dunk.).

Pecopteris exilis, 1 Phill.

P. Saportana, Hr.

Teniopteris (?).

Macrotaniopteris, of. Richthofeni,

Schenk.

Sagenopteris, sp. =? S.MIantelli (Dunk.).

Equisetum ushimarense, Yok.

Anomozamites, sp.
Nilssonia orientalis, Hr.

N. ozoana, Yok.

II. Nipponensis, Yok.

Dioonites Kotoli, Yok.

Zamites parvifolius, Geyl.

Podozamites lanceolatus, Lind. (and six varieties).

$P$. tenuistriatus, Geyl.

P. Reinii, Geyl.

Dictyozamites indicus, Fstm., var. distans.

D. grossinervis, $\mathrm{Y}_{\mathrm{ok}}$.

Cycadeospermum japonicum, Geyl.

Ginkgodium Nathorsti, Yok.

Ginkgo digitata, Brong.

G. ef. lepida, $\mathrm{Hr}$.

G. Sibirica, Hr.

Czekanowskia rigida, Hr. (?).

Taxites, sp.

Pinus, ef. prodromus, $\mathrm{Hr}$.

P. Nordenskjoldi, Hr.

Palissya, sp.

Vallionerites jurassicus, Hr. (?).

Carpolithes ginkgoides, Yok.

The following are the species enumerated by Nathorst:-

Onychiopsis elongata (Geyl.).

Cladophlebis, sp.

Cf. Nilssonia orientatis, Hr.

N. cf. Schaumburgensis, Dunk.

Znminphyllum Buchianum (Ett.).

Z. Naumanni, Nath.

Pecopteris Geyleriana, Nath. =Cladophlebis Dunkeri (Schimp.), and (in part) Weichselia Mantelli (Brong.).
Lycopodites, sp.

Sphenopteris Göpperti, Dunk. = Ruffordia Göpperti (Dunk.). Dicksoniopteris Naumanni, Nath. Pterophyllum, cf. cutchense, Morris. Picopteris, cf. Brouniana, Dunk. Mucrotaniopteris? marginata, Nath.

\section{NEW ZEALAND.}

From some specimens of plants brought by Hochstetter from the province of Auckland, between Waikato and Whaingarra, Unger described and figured two species of ferns which he named Asplenium palcopteris (= Sphenopteris Fittoni, sp. nor.) and 
Polypodium Mochstetteri. The formation from which these were collected is spoken of as probably Wealden in age. ${ }^{1}$

The preceding sketch is by no means intended to convey the idea that all the plant-bearing beds referred to are probably of Wealden age.

A more critical and detailed comparison of the species mentioned in the above lists will be made after the descriptions of the English specimens have been completed. Very possibly some of the plants which have been quoted as Jurassic in age may have to be correlated eventually with the typical Wealden floras; but in this introductory reriew there hare simply been given those plant lists which include species of undoubted Wealden affinities, or, in other words, of which Wealden floral elements form a more or less conspicuous part. The plants described by Bartholni ${ }^{2}$ from Bornholm are spoken of as Jurassic in age, but it seems not at all unlikely that the evidence will be found to be rather in favour of a Lower Cretaceous horizon. It may be found that Wealden plant beds are also represented in Sweden; at least one characteristic species, Wreichselia IIantclli (Brong.), has been recorded from Swedish strata.

There are other records of plants to which allusion might be made as including at least one Wealden species, but it may suffice to mention two instances. In a notice by Tate in the Journal of the Geological Society for 1867 there is a plant figured under the name Sphenopteris antipodum, Tate, ${ }^{3}$ from the Geelhoutboon beds in the Uitenhage series (Lower Cretaceous) of South Africa. This fossil is compared by the author of the species to Sphenopteris Jugleri, Ett., but there appears to be a much closer resemblance to Onychiopsis (Sphenopteris) Mrantelli (Brong.), and, indeed, I have decided to include Tate's fragment under this characteristic Wealden species. ${ }^{4}$

1 Reise Fregatte Norara, rol. i. Abth. ii. p. 1.

2 Bot. Tid. Bot. For. Kjövenhavn, vol. xviii. Heft i. 1892, p. 12.

3 Quart. Journ. Geol. Soc. vol. xxïi. 1867, p. 146.

4 p. 44. 
From the Cretaceous flora of Niederschöna in Saxony, Engelhardt ${ }^{1}$ has recently recorded this same species, Sphenopteris Irantelli, Brong., but unfortunately he does not give figures of any of the specimens.

No mention has been made of those countries or districts in which fossiliferous strata have been described containing only animal fossils, but which are probably homotaxial with typical Wealden strata. The supposed Wealden rocks of Spain described by Linares $^{2}$ and the strata, presumably of the same age, of Columbia, South America, described by Major Plant,, ${ }^{3}$ afford instances of such fresh-water beds.

In the Second Part of this Catalogue it is intended to complete the description of the English Wealden plants. We shall then be in a much better position to deal with such general questions as (i) the distribution of Wealden plants throughout the world; (ii) the ralue of such plants as evidence of geologic age; (iii) the Wealden climate; (ir) the relation of the Wealden flora to the vegetation of earlier and later periods.

1 Abh. Isis. Dresden, 1891, p. 79.

2 Ann. Soc. Españ. Hist. Nat. vol. vii. 1878, p. 87.

3 Proc. Lit. Phil. Soc. Manchester, vol. xvi. 1877, p. 50. 


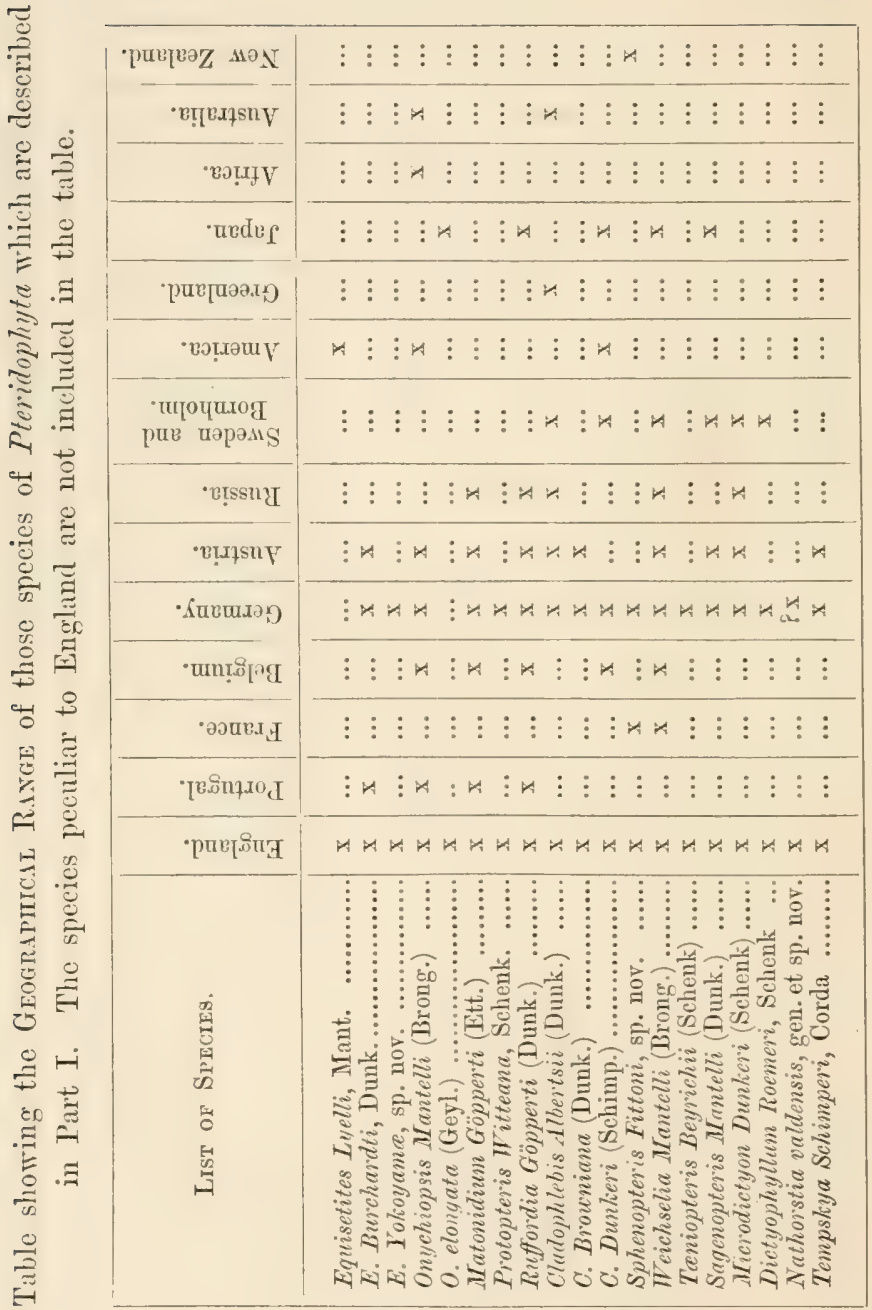


List of Thallophyta, Charophita, Bryophyta, and Pteridophyta described in the present rolume, with the geological horizon, locality and local of the type specimens.

$\dagger$ SPECIES CONFINED TO ENGLAND.

\section{THALLOPHYTA.}

† Algites valdensis, sp. nov., Fairlight Clays, Ecclesbourne. (British Museum.)

† Algites catenelloides, sp. nov., Fairlight Clays, Ecelesbourne. (British Museum.)

\section{CHAROPHYTA.}

† Chara Kinnuttoni, sp. nor., Fairlight Clars, Cliff End, near Hastings. (British Museum.)

\section{BRYOPHYTA.}

$\uparrow$ IIarchantites Zeilleri, sp. nov., Fairlight Clays, Ecclesbourne. (British Museum.)

\section{PLANTÆ INCERTE SEDIS.}

Specimen A. Fairlight Clays. (British Museum.)

Specimen B. Fairlight Clays. (British Museum.)

\section{PTERIDOPHYTA.}

Equisetites Lyelli, Mant., Hastings. Sands, Pounceford.

Equisetites Burchardti, Dunk., Hastings Sands, near Bückeburg, Westphalia.

Equisetites Yokoyama, sp. nov., Fairlight Clays, Ecclesbourne. (British Museum.)

Onychiopsis Mantelli (Brong.), Hastings Sands, Tilgate Forest.

Onychiopsis elongata (Geyl.), Bathonian (?), Valley of Tetorigawa, Province Kaga, Japan. $\uparrow$ Acrostichopteris Ruffordi, sp. nov., Fairlight Clays, Ecclesbourne. (British Museum.)

Matonidium Göpperti (Ett.), Hastings Sands, Harrel, near Bückeburg, Westphalia. (Berlin.)

Protopteris Witteana, Sehenk, Hastings Sands, Stemmen, near Hannover. (Collection of Obergerichtsdirector Witte, Hannover.)

Ruffordia Göpperti (Dunk.), Hastings Sands, near Bückeburg. 


\section{PTERIDOPHYTA-continued.}

Ruffordia Göpperti, var. Iatifolia, Fairlight Clays, Ecelesbourne. (British Museum.)

+ Cladophlebis longipennis, sp. nov., Fairlight Clays, Ecclesbourne. (British Museum.)

Cladophlebis Albertsii (Dunk.), Hastings Sands, Dornberg, near Bielefeld, Westphalia.

Cladophlebis Browniana (Dunk.), Hastings Sands, Süntel, Westphalia.

Cladophlebis Dunlieri (Schimp.), Hastings Sands, Stemmen, near Hannover.

† Sphenopteris Fontainei, sp. nov., Fairlight Clays, Ecclesbourne. (British Museum.)

Sphenoptris Fittoni, sp. nov., Fuirlight Clays, Ecclesbourne. (British Museum.)

Ireichselia Mfantelli (Brong.), Hastings Sands, Tilgate Forest.

Taniopteris Beyrichii (Schenk), Böhlhorst, near Minden. (Berlin.)
+ Taniopteris Beyrichii, var. superba, Fairlight Clays, Ecclesbourne. (British Museum.)

† Taniopteris Dansoni, sp. nov., Fairlight Clays, Ecclesbourne. (British Museum.)

Sagenopteris Mantelli (Dunk.), Hastings Sands, Borglok, near Osnabrück.

Microdictyon Dunkeri (Schenk), Hastings Sands, Osterwald, ete. (Berlin and Gïttingen.)

† Phyllopteris acutifolia, sp. nov., Fairlight Clays, Ecclesbourne. (British Museum.)

Dictyophyllum Roemeri, Schenk, Hastings Sands, Obernkirchen. (Würzburg.)

Nathorstia valdensis, sp. nov., Fairlight Clays, Ecclesbourne. (British Museum.)

Tempskya Schimper, Corda. (? Strassburg.) 


\section{NOTES ON THE}

\section{COLLECTIONS REFERRED TO IN PART I.}

Beckles Coll._Some good specimens of Equisetites and Weichselia from this Collection.

Darison Coll.-Several examples of Wealden plants from the neighbourhood of Hastings.

Mantell Coll.-This Collection includes various plants from Tilgate Forest and other localities.

Rufford Coll.-The majority of the specimens described in this Catalogue were collected by Mr. Rufford from Wealden strata at Ecclesbourne and other localities near Hastings. With the exception of a few specimens presented by Mr. Rufford to the Museum in 1885, most of the plants have been acquired by purchase since that date.

In addition to the specimens contained in the above collections there are a ferv which were presented by Mrs. Burnett and Mr. J. E. H. Peyton. 


\section{LIST OF WOODCUTS.}

PAGE.

Fig. 1. Chara Knowltoni, sp. nov. . . . . . . . . . 13

" 2. Equisetites Tokoyamce, sp. nov. . . . . . . . 33

" 3 and $3^{*}$. $\quad$. . . . . . . 33

"4. Onychiopsis Mantelli (Brong.) . . . . . . . 50

" $5 . \quad$ " . . . . . . 50

" $6 . \quad$ " . . . . . . 52

" 7. Matonidium Göpperti (Ett.) • . . . . . . . 66

" 8. $\quad$ " . . . . . . . 67

"9. Cladophlebis Alberlsii (Dunk.) . . . . . . . . 97

"10. Sphenopteris Fittoni, sp. nov. . • . • • • • . 111

" $11 . \quad$ " . . . . . . . 111

"12. Weichsetia Mantelli (Brong.) . . . . . . . 120

"13.,$\quad$ • . . . . . . 120

"14. Taniopteris Beyrichii (Schenk), var. superba . . . 127

„ 15. Taniopteris Dawsoni, sp. nov. . . . . . . . . 128

" 16. Dictyophyllum Roemeri, Schenk. . . . . . . . 141

"17. $\quad$ " $\quad$. . . . . . 141 


\section{Group THALLOPHYTA.}

A heterogeneous group of plants, many of which consist of a single cell, or of a thallus without any external differentiation into stem and leaf structures. Some of the higher members hare, on the other hand, well-defined external and internal differentiation. The group is distinguished from the higher plants by the absence of true roots and rascular (conducting) tissue. In this respect it agrees with the Bryophyta; but in the latter the dirision of the regetative body into stem and leaf structures is more pronounced, and the method of sexual reproduction and alternation of generations in the life-cycle are characters which separate the two groups.

\section{Class ALG王.}

Plants provided with chlorophyll, and therefore capable of decomposing carbonic acid gas, assimilating the carbon and giving off oxygen, under the influence of sunlight. The regetative body occurs in all forms, from that of a single cell to a complicated multiccllular structure, made up of assimilating, conducting, protective, and other tissues.

The custom of naming the innumerable markings or impressions which constitute many of the so-called fossil Alge by the same generic titles as are applied to recent seaweeds is to be strongly deprecated. Several observers have furnished ample proof of the exceedingly small value to be attached to the determinations of "algal" impressions, and hare thus given a wholesome check to the indiscriminate naming of these most doubtful fossils. The application of such terms as Caulerpites, Chondrites, etc., to markings on stone which have a greater or less resemblance to the recent genera Caulerpa, Chondria or Chondrus, is very likely to lead us astray, and to be especially misleading to those who are apt to draw conclusions as to the past history of living genera from the occurrence of their names in fossil lists. As an instance 
of the misuse of one of the names, Caulerpites, the remarks of Murray on fossil Caulerpas are worthy of repetition. In his recent paper on an example of this genus from the Kimeridge clay he says - " I have examined nearly every species known to seience of those (Caulerpa sp.) at present existing ...... of all the described fossil Caulerpe or Caulerpites of which I have seen specimens and figures, there is not one which might not with equal propriety be assigned a place elsewhere within or without the regetable kingdom." In looking at the specimens of Mlurray's new species, Caulerpa Carruthersii, one casily recoguises the resemblance to the recent genus, and it is difficult to imagine to what other source such impressions could be referred. It is somewhat surprising, howerer, to find what deep and well-defined depressions hare been left in the rock by this Oolitic seawcel.

It is superfluous to point out what very little value we can attach to external form in many of the carbonaceous impressions on rock surfaces; the same general habit of thallus being found in several recent genera, and indeed in different families. Unless, therefore, we are dealing with examples where the fossil elearly shows a habit strikingly similar in form to that of a well-marked and distinct recent genus, or with specimens exhibiting a well-preserred internal structure, or elear indications of characteristic reproductive organs, by making use of recent generic names we are rather hindering than advancing the knowledge of fossil phycology. For these reasons it is safer to be content with merely pointing out such living genera as approach most nearly in habit the algallike impressions, and not commit ourselres to a doubtful and misleading affinity by referring the fossil forms to particular genera or families.

With a riew to haring some general term which may serve as a provisional generic name for fossils, which in all probability come under the head of Algre, but which it is impossible with any degree of certainty to refer to a definite recent type, I propose to use the word Algites.

Schlotheim, ${ }^{2}$ and also Sternberg in his earlier writings, adopts the term Algacites as a comprehensive title for all fossil seaweeds. In the later parts of the "Flora der Vorwelt" those "algal"

1 Phycol. Mem. pt. i. 1892, p. 13.

2 Petrefactenkunde, p. 38. 
remains, originally mentioned as species of the genus Algacites, are referred to rarious recent genera to which some resemblance in external form is considered to exist. The name Algacites has since been replaced by other terms, and appears to be no longer used as a general designation of fossil Alge of doubtful affinity. There is another term, Fucoides, which has alsu been used by Sternberg and many other palæobotanists in an equally wide sense, but such a name naturally suggests a certain resemblance to the recent genus Fucus, and is thus unsuitable if used in a more comprehensive sense.

This suggestion as to the use of a provisional and wide generic designation, such as Algites, may be considered a retrogressive step and likely to lessen our accurate knomledge of fossil Algce. If the data were generally adequate, and afforded sufficient indication of botanic affinity, any such term would be superfluous. When we consider how exceptional it is to find ourselres in a position to make definite statements, founded on satisfactory evidence, as to the family of Alge in which fossil forms should be placed, it must be admitted that we are lessening the possibilities of error by the return to more general and less definite terms.

Botanists would naturally prefer to pass orer such markings or casts which are too imperfect to admit of identification; but in spite of their apparent worthlessness from a botanical point of riew, they may be of service to the geologist, and indeed the most fragmentary material may become important when more perfect specimens have been discovered. Thus it is better to place on record even those exceedingly doubtful fossils, and to adopt a provisional name in the hope that future discoveries may throw more light upon family or generic affinity. Generic names, such as Sphenopteris, Pecopteris, etc., of Brongniart have served a most useful purpose, and by degrees these are being replacel by more definite botanical titles as fertile specimens are discorered, and so afford clues as to natural affinity. As another instance of a convenient term we may mention Rachiopteris, which Williamson has applied to those fragments of fern petioles which it is not possible to refer to particular genera. 


\section{Genus ALGITES, gen. nov.}

A generic term for those fossils which in all probability belong to the class Alge, but which, by reason of the absence of reproductive organs, internal structure, or characters of a trustworthy nature in the determination of affinity, cannot be referred with any degree of certainty to a particular recent genus or family.

\section{1.-Algites valdensis, gen. et sp. nor.}

Type. Carbonaceous impression from Ecclesbourne, near Hastings (Fairlight clay). British Museum. PI. I. Fig. 1. Registered number V. 2857.

Thallus in the form of dichotomously divided branches radiating from a centre; the branches terminating bluntly.

The apparently dichotomous habit and the shape of the thallus at once suggest a resemblance to a number of algal genera, such as Chondrus, Zonaria, Dictyota, Rhodymenia, Nitophyllum, and others. Chondrus crispus (L.), Stackh., seems the most likely species among recent forms with which to compare the Wealden impressions; its more resistant fronds appear better adapted for preservation than the more delicate structures of Rhodymenia or Zonaria. So far as habit is concerned there is indeed a striking resemblance between Algites valdensis and Nitophyllum Bonnemaisoni (Lymgb.) ${ }^{1}$ as figured by Harvey; but an equally strong resemblance may be traced on comparing the fossil specimens with examples of other recent genera. The extreme variability of Chondrus criapus is well known, and, as Mr. Murray pointed out to me, the broader type of thallus, such as we have in Algites valdensis, is inclicative of quiet pools or gently flowing water, and in marked contrast to the narrow filiform branches of specimens growing in swiftly running currents. This difference of habit, and its close rommection with the mode of life, is worth noting with reference t) fossil forms, although in the present instance it would hardly be admissible to draw any conclusions from the breadth of the thallus branches when we are in doubt as to generic relationship.

1 Harrey, pl. xxiii. fig. 2. 
The genus Chondrites is suggestive of supposed affinity with Chondria, but the definition given by Brongniart ${ }^{1}$ shows that it was intended for the reception of forms with cylindrical branches. In Schimper's "Traité de Paléontologie" the genus Chondrides" is defined as comprising fossils with cylindrical fronds, often repeatedly dichotomising, and possessing characters united in Chondria and Furcellaria among liring algæ. Those fossil algæ with flattened fronds are referred to the genus Sphcrococcides, a name previously used by Sternberg as Sphcrococcites, and defined by him as follows:- "Frons subcoriacea, plana dichotoma reI pinnata aut filiformis." ”

Schimper includes this genus in the Floridec, and considerably extends Sternberg's definition.

Seeing that the specimens from the Wealden rocks do not conform exactly to any of these definitions, and that such terms are, to some extent, associated with definite genera of recent seaweeds, it is better to make use of a wider designation, such as Algites.

There are some few fossils previously described from Mesozoic and Tertiary rocks, to which Algites valdensis shows a certain amount of resemblance.

Under the name Chondrides dolichophyllus Squinabol bas described a specimen from Liguria which has a general habit similar to the Wealden species, but differs in the narrower and longer branches. Heer's figure of Gyrophyllites Theobaldi, $\mathrm{Hr}$, in the Foss. fl. Helret, ${ }^{5}$ shows an analogous type of plant, but the generic name which he adopts was instituted by Glocker ${ }^{6}$ in 1841 for a Cretaceous fossil which resembles the genus Caulerpa much more strongly than the flattened branching algæ with which the present specimens agree. From the Jurassic rocks of East Yorkshire Leckenby ${ }^{7}$ has described a supposed alga, Fucoides erectus, which slightly resembles Algites valdensis; but the presence of a midrib and the delicate nature of the lateral parts of the branches are much more suggestive of Hepatic affinities.

1 Tableau, p. 9. See also Prodrome, p. 20, where the older name Gigartinites is defined.

2 Trait. pal. vég. vol, i. p. 168.

3 Flor. Vorwelt, fasc. vii. p. 28.

4 Contrib. Fl. foss. Liguria, vol. i. Tav. B, p. 11.

5 Pl. xlv. fig. 1.

6 Nova Acta Ac. Cæs. Leop.-Car. vol. xix. supp. ii. p. 322.

7 Quart. Journ. Geol. Soc. vol. xx. p. 74, pl. xi. figs. $3 \mathrm{a}$ and $3 \mathrm{~b}$. 
The Wealden fossils previnusly classed as Alge are not of such inportance as to require serious attention. Dunker's Confervites fissus ${ }^{1}$ is definitely stated by Schenk, ${ }^{2}$ after a careful examination of the type specimen, to be a rachis fragment of Onychiopsis (Sphenopteris) IIantelli (Brong.). The curious marking figured by Heer ${ }^{3}$ from Almargem in Portugal as Tenidium lusitanicum, Hr., has little claim to be accepted as a fossil plant, so far at least as it is possible to judge from the plate. Ettingshausen ${ }^{4}$ figures three species from the Wealden of Austria, Spharococcites chondriaformis, Ett., Confervites setaceus, Ett., and Sargassites Purtschii, Ett., but these (1) not afford trustworthy evidence as to the existence of any particular family of Alga.

In the case of the English specimens there is an obrious objection to their reference to seaweeds in the fact that they are found in a supposed fresh-water rock; this, however, does not appear to me at all a fatal objection. Narine algae are abundant enough at a river's month, and, indeed, extend some distance from the place where the fresh water flows into the sea. In the delta deposits of the Wealden rivers there might easily be embedded the fronds of shallow-water seaweeds.

There is a striking resemblance, too close to be entirely ignored, between some forms of the liverwort Reboulia hemispharica (L.), Racld., and the fossil which I have described as an alga.

\section{2857. Pl. I. Figs. 1 and 2.}

One lirrge and fairly perfect specimen of Algites valdensis; on the same slab is a smaller example of this species. The ends of the branches are in some cases more or less torn, but appear to have originally terminated bluntly. Fragments of Algites catenelloides, sp. nov., scattered over the rock surface, as small branched structures.

In addition to the species already mentioned, ef. Caulerpa arcuata, ${ }^{5}$ Schimp., from the Flysch. Near Hastings.

Beckles Coll.

V. 2857 . The reverse piece of the prerious specimen.

1 Wealdenbildung, p. 1, pl. i. fig 1.

2 Paliontographica, vol. xix. p. 208.

3 Sece. Trab. Geol. Portugal, 1881, pl. xx.

4 Abh. k.-k. geol. Reichs. vol. i. Abth. ii. No. 2, pl. iii. figs. 1-3 and 12.

5 Trait. pal. vég. Atlas, pl. iii. fig. 6. 
V. 2857b. In these specimens some of the branches show apparently perfect and blunt terminations. Fragments of Algites catenelloides. Near Hastings.

Beckles Coll.

V. $2857 c$. Portions of three specimens with the branching habit clearly seen. Traces of $A$. catenelloides. Near Hastings.

Beckles Coll.

2.-Algites catenelloides, gen. et sp. nov.

Type. Small carbonaceous fragments on the same piece of rock with the type specimen of $A$. valdensis. British Museum. V. 2857. Pl. I. Figs. 1 and 2.

Small carbonaceous impressions of an apparently dichotomously branched thallus; the branches show indistinct signs of constrictions, suggesting a jointed structure, as in Catenella.

These small branched fragments, which show in places what appear to be elliptical joints, as represented in Pl. I. Fig. $2 a$, are closely associated with the specimens of the previous species. I am indebted to Miss Barton for the suggestion that Catenella approaches most closely in habit to these delicate impressions; the form of the thallus, both as regards the branching, and what appear to be elliptical members making up the branched axes, has a striking similarity in the fossil and recent specimens. Another fact of importance is the frequent association of Chondrus crispus and Catenella on our coasts at the present day. This occurrence, in such close proximity, of two fossil forms, whose external form is in close agreement with two recent genera, is of some value as confirmatory evidence in the question of botanic affinity. It must, at the same time, be candidly admitted that no great importance ought to be attached to identifications or comparisons based on mere impressions of external form.

Vast numbers of impressions, animal trails and markings, which owe their origin to many and exceedingly diverse causes, have been assigned to that group of plants which has come to be regarded as the receptacle for all doubtful specimens which often afford little or no evidence of any regetable nature whatsoever. The result of this has been to intensify that spirit of scepticism which ought always to influence the conduct of palæobotanists. There is, on the other hand, the danger of allowing ourselves to go too 
far, and to be unduly prejudiced by such extreme expressions of opinion as those of Nathorst and his followers. In the present instance I do not wish to make a definite assertion that these two species of Wealden fossils are undoubtelly fragments of Chondrus and Catenella, but merely indicate such points of agreement as appear to exist.

These pieces of Algites catenelloides, Mr. Murray reminds me, may also be compared to small Laurencias.

V. 2857. P1. I. Figs. 1 and 2. Sereral pieces of the branched thallus close to the specimens of Algites valdensis.

V. $2857 b$ and V. $285 \%$. A few fragments associated with A. valdensis on the same piece of rock. Near Hastings.

Beckles Coll. 


\section{Group CHAROPHYTA, Migula.}

\section{Family CHARACE巴.}

The Characece or Stoneworts possess certain characters, both structural and biological, which denote a considerable advance in organization beyoud the less complex Thallophyta. On the other hand there are sufficient differences betreen them and the Bryophyta to exclude them from that group. If we follow Migula, who has recently written an exhaustive account of the Characee for Rabenhorst's "Kryptogamen Flora,"1 and adopt a new class division, Charophyta, we shall best represent the isolated position of these plants, and recognize that they occupy a place between the Thallophyta and the Bryophyta.

\section{Genus CHARA, Vaillant. L.}

[Linn. Hist. Acad. Gen. Plant, 1737, p. 326.]

[Vaillant, Hist. Ac. R. Sci. Paris, 1719.]

Vaillant ${ }^{2}$ was the first to apply this generic term to the widelyspread Stoneworts; he enumerates nine species in an article published in 1719. The "fruits" of Chara when first discorered in Tertiary rocks of the Paris basin were described by Lamarck ${ }^{3}$ under the name Gyrogonites, and not recognized as plant remains. In 1812 Léman ${ }^{4}$ contributed a "note sur la Gyrogonite," and pointed out the real nature of Lamarck's fossils.

It is convenient to apply the name Chara to those fossil remains which in all probability belong to the Characea. The material

2 Vol. v. p. 93.

2 Hist. Ac. R. Sci. 1719, p. 17, pl. iii.

3 Ann. Mus. Hist. Nat. vol. ix. pl. xv. fig. 7 and vol. xv. pl. xxiii. fig. 12.

4 Nouv. Bull. Sci. Paris, vol. iii. Ann. 5, No. 58, p. 108.

In Zittel's "Handbuch der Palaeontologie," Abth. ii. p. 43, the reference to Léman's paper is given as the "Annales" (rol. xv.) instead of Nouv. Bull. 
which usually supplies the eridence for the existence of these plants in rocks of various ages, is too imperfect to enable us to decide accurately whether the fragments should be referred to Chara, Nitella, or other genera of Characea.

In view of this difficulty it is better, therefore, to describe all the Characeous "fruits" by the term Chara, if we regard the generic name, when applied to fossils, rather in the sense of a representative of a family than of the genus Chara as defined in the more recent works on this anomalous group.

We frequently find the statement that the oldest known fossil Charas are those which have been found in beds of Muschelkalk age from Moseow; but in no case hare I been able to discorer a reference to the author who first noted this occurrence. It is by no means improbable that we must go much farther back in the geologic scries to find the earliest traces of Chara "fruits." In a paper in the American Journal of Science for 1889, Knowlton ${ }^{1}$ gives three figures of some "problematic organisms" which it is difficult to believe can be anything but Chara oogonia. They are described as minute spirally-grooved bodies $1.50 \mathrm{~mm} .-1.80 \mathrm{~mm}$. long, and $1.70 \mathrm{~mm}$. broad, with a small aperture at one end; these bodies occur in large numbers in Lower Devonian-Carboniferous sandstones, and were mentioned in 1873 by Meek, ${ }^{2}$ who spoke of them as showing all the external characters of Chara. Knowlton recognizes the strong likeness to this genus, but quotes various opinions which throw a good deal of doubt on the plant-nature of these small fossils. One objection is that the fossil bodies hare on their surface the marks of more than five cells, the number making up the envelope of recent Charc oospores; and in the living forms these spirally-placed cells are twisted to the left, but in the fossils to the right; this, howerer, Knowlton suggests is "no rital objection to the supposition that this might have been an archaic or original type from which the more modern forms have dereloped." 3

Other arguments against their Characeous affinities are (i) the

1 I am indebted to Mr. Davies Sherhorn for calling my attention to this paper and to C'lrich's genus Mocllerina mentioned below. Imer. Journ. ser. jii. rol. xxxvii. p. 202.

2 Report Geol. Surv. Ohio, vol. i. pt. ii. p. 219.

3 Loc. cit. p. 204. 
large numbers uniformly scattered through the rock-mass, and (ii) their occurrence in strata formed in water of considerable depth.

The generic name Calcisphera was proposed by Williamson ${ }^{1}$ for certain small bodies common in Carboniferous Limestone rocks in the neighbourhood of MLel, North Wales; this name is applied to the American fossils by Knowlton with the specific designation C. Lemoni, Knowl.

From the same geological horizon Darson ${ }^{2}$ has described what he regarded as a foraminiferal species, Saccammina (Calcisphera) Eriana, Daws., and these, Brady suggested, probably belong to the same group as the forms figured by Knowiton. Diwson's figures are not nearly so suggestive of Chara, as are those of Knowlton. Since Darson named these Devonian fossils, Ulrich, ${ }^{3}$ in ignorance apparently of previous descriptions, instituted a new foraminiferal genus, Moellerina, for their reception. From the Carbonifurous Limestone of Gloucestershire Wethered ${ }^{4}$ has recorded another form, which he places in Williamson's genus Calcisphera, but with the belief that it is of a Protozoan nature. Enough has been said to show the possibility of our haring to go back to Deronian strata for the earliest specimens of Chara. Without having seen Knowlton's material, and being aware of the difficulties pointed out by experienced specialists, it must be admitted that the figured specimens exhibit a rery marked resemblance to Characeous fruits : the reasons brought forward against accepting this resemblance as proof of identity do not appear by any means decisire. The number of enreloping cells need not be regarded as fixed and unalterable, and a similar occurrence of large numbers of Charas in the rock matrix may be noted in the case of the Paris Basin fresh-water rocks of Eocene age. In most cases the plants are represented by the so-called "fruits," which are simply the oospores enclosed in the spirally arranged cells of the envelope, or, not infrequently, without the encasing cells. Remains of the regetative organs are rare, and such as have been described in a fossil state are of little or no interest from a botanical point of view.

1 Phil. Trans. 1880 , p. 521.

2 Canad. Nat. n.s. vol. x. p. 1.

3 Geol. Mag. 1886, n.s. Dec. 3, vol, iii. p. 374.

4 Quart. Journ. Geol. Soc. vol. xliv. Proc. p. 91. 
In rocks of the Jurassic system several species have been discovered. Saporta, ${ }^{1}$ in his important contributions to the Jurassic botany of France, institutes a new species, Chara Bleicheri, from Oxfordian rocks at Cajase in the Départment Lot.

Heer ${ }^{2}$ named a species, Chara Jaccardi, Hr., from the Purbeckian of Villers-le-lac and other localities in the Canton Neuchatel; this species is also recorded by Saporta, ${ }^{3}$ on the authority of Giradot, from the same geological horizon in the neighbourhood of Pont de la Choux. Another species, Chara Ilaillardi, Sap., has recently been described from this district by Saporta, ${ }^{4}$ but his figures show the spiral markings of the encasing cells almost longitudinally placed, and, indeed, the drawings are by no means convincing as regards botanic affinity.

Heer's species, Chara Jaccardi, IIr., is quoted by Schenk ${ }^{5}$ from beds which may be of Wealden age, at Locle in the Canton Neuenburg. In Britain we have a reference by Phillips ${ }^{6}$ to the occurrence of Chara in the "Upper part of the Wealden deposits" of Swanage Bay, Isle of Purbeck; the same genus is included in the list of Isle of Wight fossils in Bristow's Memoir ${ }^{7}$ on the Geology of that island, from a locality between Brixton and Atherfield.

So far as I am able to discover, no specific name has been applied to these English Mesozoic Charas. In the Museum of Practical Geology, Jermyn Street, there is a specimen showing a number of hollow casts of the Isle of Wight Charas; these should probably be included in the species Chara Fnowltoni, sp. nov. A few of the more clearly preserved casts show that there were about 10-12 almost horizontal lines on the surface of the oogonia. The casts are somewhat longer and narrower than the impressions from Ecclesbourne, but this may be due to the fuct that the latter have been more crushed, and have, therefore, an apparently greater breadth.

1 Pal. Franç. sér. ii. vol. i. p. 214, pl. ix. figs. 8 and 9.

2 Urwelt, 1879, p. 176.

${ }^{3}$ Pal. Franç. sér. ii. vol. i. p. 216, pl. ix. figs. 12 and 13.

4 Ibid. ii. vol. iv. p. 499, pl. lxxii bis.

5 Palæontographica, vol. xix. p. 204, pl. xxv. fig. 1.

${ }^{6}$ Quart. Journ. Geol. Soc. 1858, p. 46.

7 Mem. Geol. Surv. 1889, p. 258. 


\section{1.-Chara Knowltoni, sp. nov.}

Type. Imperfectly preserved oogonia discovered by Mr. Rufford at Cliff End, near Hastings. British Museum. Registered number V. 1070 . Woodeut, Fig. 1.

Oogonia broadly oval in form, the largest specimens about $\cdot 5 \mathrm{~m}$. long and approximately the same brealth at the broadest part. Surface marked with eleven or twelve ridges, arranged in the form of a flattened spiral very little removed from the horizontal.

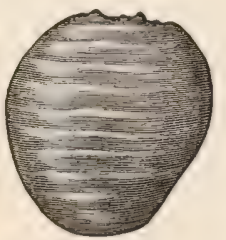

Fig. 1.-Oogonium of Chara Knowltoni, sp. nor. (V. 1070a), $\times 30$.

Each specimen is corered by a thin and brittle lajer of carbonaceous matter, and in all probability the ridged surface is that of the enveloping cells, the substance of which is left as a black film moulded on the ridged and furrowed surface of the oospore.

The examples on which this species is founded are confesselly mengre, and hardly such as to warrant the institution of an additional species. Such characters, however, as are arailable indicate very clearly marked differences from the Wealden species previously described. It may, therefore, serve a useful purpose to designate the British specimens by a new name, prorided the fact be kept in mind that the material hitherto found in the English beds is not at all adequate for the purposes of thorough specific definition. I have rentured to name this species after Mr. Knowlton, who has recently added to our knowledge of fossil Charas.

The present species differs from the other Wealden form, Chard Jacrardi, in haring many more surface ridges, and in its more globular and less elongated shape. The globular form may, howerer, as preriously suggested, be, to a certain extent, the result of flattening.

A specimen figured by Squinabol ${ }^{1}$ from Tertiary beds of Liguria,

1 Contrib. Fl. foss. Liguria, vol. ii. p. 7, pl. xii. figs 1 and 2. 
and referred by him to Chara Meriani, A. Br., agrees fairly closely with our Wealden form.

Another species, Chara Stantoni, ${ }^{1}$ recently described by Knowlton from the Upper Cretaceous Bear-River formation of North America, agrees in the large number of almost horizontal ridges with Chara Knowltoni, but differs in shape.

Among English Tertiary species there is a distinct similarity to a specimen of Chara medicaginula, figured by Lyell, ${ }^{2}$ showing the "nut" enclosed in the "integument." The inner part ("nut") has a close resemblance to the present species.

The common recent species Chara fotida, A. Br., possesses oogonia not far removed in appearance from the Wealden type, but, as Lyell points out in reference to Tertiary species, the fossil oogonia are more globular than those of living British species.

V. $10 \%$ a. Woodcut, p. 13, Fig. 1.

Some of the oogonia are fairly well preserved and show the characteristic markings clearly. Near Hastings.

Presented by P. Rufford, Esq., 1885.

V. 1070. Sereral oogonia scattered in the matrix. Near Hastings. Presented by P. Rufford, Esq., 1885.

V. 2282. A cluster of oogonia closely crowded together, with odd ones seattered about. The spherical form well shown, but markings indistinct. Ecclesbourne.

Rufford Coll.

V. 2808. Sereral specimens in an argillaceous matrix, some with the surface markings fairly clear. Ecclesbourne.

Rufford Coll.

1 Bot. Gazette, vol. xriii. p. 141.

2 Trans. Geol. Soc. ser. ii. vol. ii. 1826, p. 90, pl. xiii. fig. 3. 


\section{Group BRYOPHYTA (MUSCINEE).}

There is a well-marked and characteristic alternation of generations in the life-history of the members of this group; the Oophyte generation (moss plant) being the more conspicuous of the two. No vascular tissue, and no true roots.

Our knowledge of fossil mosses and liverworts is lamentably deficient, and, indeed, the eridence upon which many of the socalled fossil mosses have been named is far from satisfactory. Scanty as the material is on which the geological history of these plants is founded, we are not justified in assuming that they are unrepresentedin pre-Tertiary times. ${ }^{1}$

The earliest representative of the IFusci to which reference need be made is one which was described in the "Comptes Rendus" for $1885^{2}$ by Zeiller and Renault from the Coal-Measures of Commentry; this species, Muscites polytrichaceus, has since been figured by the same authors in their work on the Commentry fossil flora. ${ }^{3}$ As usually happens in the case of fossil mosses, there are no signs of a capsule. The figures of this carboniferous species are certainly much more suggestive of the regetative parts of a moss than any other plant. M. Bescherelle suggested the two recent genera, Polytrichum and Rhizogonium, as the nearest recent forms as regards the characters of the vegetative parts. In connection with Palæozoic mosses the comparison made by Solms-Laubach is worth noting ${ }^{4}$; he compares Lycopodites Maakii from the Coal-Neasures of North America, and $L$. uncinatus, also of Carboniferous age, to certain of the recent Hypnece. Passing on to the Mesozoic system, we have further evidence for the existence of this group of plants, as Starkie Gardner has shown in his paper "On Mesozoic Angiosperms." ${ }_{5}$ He had occasion to

1 Bower. Annals Bot. vol. v. p. 130.

2 Vol. c. p. 660 .

3 Fl. foss. Houill. Commentry, pl. xli. figs. 2-4.

4 Fossil Botany, p. 186.

5 Geol. Mag. 1886, p. 203. 
examine a specimen originally described and figured by Buckman ${ }^{1}$ under the name Najadita, from the plant bed at the base of the Lias, near Bristol; his inspection of this supposed monocotyledon led him to the conclusion that Buckman's plant was probably closely allied to the common fresh-water moss Fontinalis. In this opinion he was supported by Messrs. Carruthers and MLurray, of the British Museum, to whom the specimen was shown.

In a footrote to Gardner's paper the important fact is added that a capsule had been sent to him by Mr. Brodie from the same locality.

The argument advanced by Heer ${ }^{2}$ in the "Urwelt der Schweiz" for the existence of Triassic mosses is well known. In describing some Lias insects from the rocks of Schambelen, Heer notes the absence of fossil fungi in these rocks, but goes on to say that their presence may be inferred from the occurrence of certain genera of beetles. The same kind of reasoning is made use of in the case of mosses; four species of Byrrhus, found in the Schambelen Lias, are supposed to warrant the assumption that mosses were also in existence, because at the present day the nearest living allies of those Schambelen beetles derive their food from mosses. Such rensoning can hardly be accepted in the accumulation of reliable evidence for the geological history of particular classes of plants.

A Cretaceous moss has been figured by Ettingshausen and Debey from the Aachen and Maestricht rocks under the name Iluscites cretaceus $^{3}$; the figure of the type specimen shows a very small and imperfect fragment. The plant fragments figured by Roemer, ${ }^{*}$ and described by him as Muscites imbricatus and $\boldsymbol{M}$. falcifolius, from the North German Wealden beds, are most probably pieces of coniferous branches, and certainly of no value as records of Wealden mosses. The specimen figured by Dunker, from the same district, as Muscites Stembergianus, is in all probability a fragment of a coniferous branch. From the Tertiary rocks sereral authors have described species of Muscites, but in nearly all eases the determinations are based solely on fragments of regetative

1 Quart. Journ. Geol. Soc. vol. vi. p. 413.

2 Urwelt, 1879, p. 99.

3 Denkschr. k. Ak. Wiss. mat. nat. Cl. vol. xvii. p. 185, pl. i. fig. 6.

4 Verstein. Ool. Geb. p. 10, pl. xvii. fig. 2.

5 Wealdenbildung, p. 20, pl. vii. fig. 10. 
organs, and these alone are not often trustworthy guides: there is an exception in the case of Gymnostomum ferrugineum, ${ }^{1}$ figured by Ludwig, where the capsule is preserved with portions of the mossplant stem.

The paliobotany of the Hepatica is no more satisfactory. Of Palæozoic liverworts there appear to be no records preserved. A single specimen of a plant with dichotomously lobed flat fronds has been described by Fliche and Bleicher as a new species of Marchantia, ${ }^{2} M$. oolithicus; it was discovered in Lower Oolite rocks in the neighbourhood of Nancy. The authors of the species point out that such forked laminar structures may be referred to certain lichens, algæ or liverworts; in this case the latter class is the one chosen.

In speaking of fossil algæ reference was made to Fucoides erectus, Leck., from the Yorkshire Oolite, as being possibly a liverwort and not an algal impression.

The Tertiary Hepatica are more satisfactory, notably some figured by Saporta ${ }^{3}$ from the Paris Basin showing distinct male receptacles. From the Baltic Amber Göppert ${ }^{4}$ has determined various examples of the Bryophyta, and instituted the generic term Jungermannites to denote the existence of certain supposed hepatics which resemble the Jungermannia rather than the Marchantia section.

\section{Class HEPATICA.}

The vegetative dorsiventral body is in the form of a thalloid creeping structure (Thalloid Liverworts), or a creeping stem with thin leaves which are always without a midrib (Foliose Liverworts). Protonema feebly developed.

\section{Order MARCHANTIEA.}

Vegetative body of the thalloid type, with or without a midrib; branches of the "thallus" more or less clearly forked.

1 Palæontographica, vol. viii. p. 160, pl. 1xiii. fig. 9.

2 Bull. Soc. Sci. Nancy, sér. ii. vol. v. pp. 67, 68, fig. 1.

3 Mém. Soc. Géol. France, sér. ii. vol. viii. p. 289.

4 Bernstein, p. 113. 


\section{Genus IMARCHANTITES, Brongniart.}

[Tableau, p. 12.]

Vegetative body of laminar form, with apparently dichotomous branches, and agreeing in habit with the recent thalloid Hepatice, as represented by the genus Marchantia.

Brongniart's term Marchantites is, in the present instance, preferable to Irarchantia; the latter would suggest a fossil which might reasonably be regarded as a species of the recent genus; the former has a wider meaning, and, if used in the broad sense indicated in the above definition, would refer rather to a type of vegetative body than to a special genus.

\section{1.-Marchantites Zeilleri, sp. nov.}

Type. Specimen in the British Museum. V. 2330. Discorered by Mr. Rufford. Pl. I. Fig. 3.

"Frond" repeatedly divided by forked branching, apparently dichotomous. Average breadth about $3 \mathrm{~mm}$; the branches have a distinct and fairly broad midrib, and on either side of the central axis are thin and filmy.

I have named this Wealden species after Professor Zeiller, of Paris, who is one of the authors of the oldest known species of moss, and whose labours in palæobotany hare done so much to establish the subject on a more scientific foundation.

In habit and size this species very elosely resembles Marchantia Chenopoda, Linn., from tropical America. No other genus, so far as resemblance in habit is concerned, agrees so nearly with the Wealden form as Irarchantia, but without trace of either male or female receptacle, or other aids to identification, no great stress should be laid on the comparison. There is the same branching habit and distinct midrib in Leckenby's species, Fucoides erectus. ${ }^{1}$ In both the midrib is clearly shown by the much darker colour of the median portion of the thalloid impressions; the thinner lateral parts in the present species appear almost like brown stains on the matrix. A somewhat similar form, but without any striking resemblance, and, indeed, of much smaller size, is figured by Debey

1 Quart. Journ. Geol. Soc. vol. xx. p. 74, pl. xi. fig 3. 
and Ettingshausen, under the name Halyserites gracilis, ${ }^{1}$ from the Cretaceous of Aachen and Maestricht. This so-called alga might also be compared to a fragment of a filmy fern frond.

V. 2330. Pl. I. Fig. 3.

This specimen shows rers clearly the habit of the plant, and especially the marked contrast between the sharply defined black midrib and the light brown impressions of the more delicate lateral portions. Eeclesbourne.

Rufford Coll.

V. 2330\%. Practically identical with V. 2330. Ecclesbourne.

Rufford Coll.

V. 2334. Several smaller pieces of the branched thalloid body: on the same slab of ironstone are fragments of Sphenopteris Fontainei, sp. nov. Ecclesbourne.

Rufford Coll.

\section{PLANTE INCERTA SEDIS.}

In Pl. I. Figs. 7 and 8 , two specimens are represented which it is difficult to refer, with any degree of certainty, to definite genera, but which may be briefly described here as possibly referable to the Pteridophyta.

Specimen A. Pl. I. Fig. 7. V. 2370.

Ecclesbourne.

Rufford Coll.

The figure shows a clearly preserved and sharply cut black structure projecting in a button-like form from the rock matrix. In the centre is a distinct depression, and from this extend numerous radiating ridges which curve downward at the periphery; these rilges appear to be the projecting midribs of leaf-segments, which terminate acutely, and are fused together laterally in the form of a circular sheath. I am inclined to regard the specimen as an Equisetaceous leaf-sheath, but prefer to leave it unnamed in the hope of fresh discoveries affording more definite evidence as to its botanical position.

1 Denkschr. k. Ak. Wiss. math. -nat. Cl. vol. xvi. 1859, p. 61, pl. i. figs. 1-2. 
A rery similar fossil has been figured by Fontaine from the Potomac beds of Baltimore as "an undetermined plant"; his specimen is smaller, but very similar in form; it shows a circular orifice in the centre, a character not noticed in the English example. The Potomac fossil is described as more like a leafsheath of Equisetum than anything else. Ettingshausen ${ }^{2}$ has figured a small object from the Wealden of Zöbing, described as a "Patellenähnliches Gebilde," which may be compared to our figured specimen. In the genus Phyllotheca there is a certain amount of resemblance to the present specimen in the form of the leaf-sheaths. Zigno's figures of Phyllotheca equisetiformis, Zig., ${ }^{3}$ represent stems with nodes clasped by leaf-sheaths deeply divided into acute and slightly incurred segments. In the case of a detached leaf we should expect, however, to have a circular structure with a central aperture. In a leaf-sheath of Phyllotheca Schtschuraroskii, Schmal., ${ }^{4}$ from the Russian Jurassic rocks, there is also a certain similarity as regards size and general form.

Specimen B. Pl. I. Figs. 8 and 9. V. 2328.

Ecclesbourne.

Rufford Coll.

This specimen consists of a repeatedly branched structure bearing small and closely arranged leares; the axes of the branches are distinguished in several places by the presence of a white mineralization substance in the form of fine longitudinal lines, suggestive of a slender and woody central cylinder; the general habit is somewhat stiff; length $3 \mathrm{~cm}$.

MIr. Carruthers, to whom I showed the specimen, recognized a resemblance to the sporangiferous branches of some of the Lycopodium Phlegmaria group, ${ }^{5}$ and pointed out the possibility that the small carbonaceous patches shown in Fig. 9 in the axis of the lefthand leares may be the remains of sporangia. In addition to these black patches the enlarged piece of a branch (Fig. 9) shows the pointed and slightly falcate leaves, which appear to occur in two

1 Potomac Flora, p. 276, pl. clxxiii. figs. 11 and $11 a$.

2 Abh. k.-k. geol. Reichs. vol. i. Abth. iii. No. 2, p. 32, pl. iii. fig. 20.

3 Flor. foss. Oolit. vol. i. p. 60, pl, viii. fig. $5 a$, ete.

4 Schmalhausen. Mém. Ac. Imp. St. Pétersbourg, sér. rii. vol. xxrii. No. 4, 1879, pl. vi. fig. 3 .

5 Baker, Fern-allies, p. 19. 
alternating rows. There is certainly a marked resemblance between some specimens of fertile branches in members of the Lycopodium Phlegmaria group and the Wealden fragment; but the nature of the fossil renders it unwise to gire expression to this resemblance by adopting the name Lycopodites.

The occurrence of this genus in Wealden rocks has previously been hinted by Mantell ${ }^{1}$; he includes ? Lycopodites in a list of fossil plants from Tilgate Forest.

Nathorst" figures and describes a specimen as "undoubtedly Lycopodiaceous," from a Japanese locality which has afforded a flora with a distinct Wealden facies. In Saporta's recent list of plants from the Wealden of Portugal ${ }^{3}$ there are included certain species of Lycopodiaceous plants.

At first sight the specimen suggests, as Mr. Rufford pointed out, a moss-like plant. So far as I have been able to determine there are no species of true mosses which show any close similarity in habit to the fossil, but in the Hepatice there are some forms in which the resemblance is distinctly close, e.g. the genus Porella.

A strong argument, however, against adopting such a generic term as Jungermannites is the indication of a woody axis, to which reference has already been made.

Finally the possibility must be noted that the real affinities of specimen B may eventually prove to be with the Conifere. Cf. Pl. I. Fig. 8, with Heer's figures of Widdringtonites Reichii (Ett.) and Juniperus macilenta (Hr.), ${ }^{5}$ both from the Cretaceous of Greenland; also Lesquereux's figure of Glyptostrobus gracillimus, ${ }^{6}$ Lesqx., another Cretaceous conifer.

1 Trans. Geol. Soc. ser. ii. vol. iii. 1835, p. 213.

2 Denkschr. k. Ak. Wiss. math.-nat. Cl. vol. Ivii. 1890, p. 50, pl. ii. fig. 3.

3 Compt. Rend. vol. cxiii. 1891, p. 249.

4 Fl. foss. Aret. vol. vii. 1883, pl. lii. fig. 5.

5 Ibid. vol. vi. 1882, pl. xxxv. fig. 10.

6 Rep. U.S. Geol. Surv. vol. vi. 1874, pl. i. fig. 11. 


\section{Group PTERIDOPHYTA. (VASCULAR CRYPTOGAMS.)}

Plants with a highly organized sporophyte generation, possessing true vascular (conducting) tissue, and true roots.

With the exception of Isöetes, Botrychizm, Helminthostachys, and, according to recent observations, Equisetum, 'there is no secondary thickening in the vegetative structures of the living genera included in this group. Among fossil genera secondary thickening appears to have been common.

The Pteridophyta differ from the Bryophyta in the greater advance in physiological division of labour as expressed in the more complete differentiation of tissues. The presence of a true vascular system and the possession of true roots at once separate the Pleridophyta from the next lower group of plants. In the liigher group the sporophyte generation is the more conspicuous; in the Bryophyta the gametophyte (oophyte) generation is more prominent.

\section{Class EQUISETIN E.}

Leares in whorls and small in proportion to the stem, in the form of sheaths, with long or short teeth, clasping the stem at the nodes.

The fertile branches terminate in spikes formed of leares modified in the form of peltate scales arranged in close whorls with sporangia attached to their inner surface.

\section{Family EQUISETACE正.}

Contains the single recent genus Equisetum, and the fossil species included under the generic name Equisetites.

1 Cormack, Annals Bot. vol. vii. 1893, p. 63. 


\section{Genus EQUISETITES, Sternberg.}

[Flor. Vorwelt, vii. 1838, p. 43.]

A general name applied to such fossil remains as closely resemble the recent genus Equisetum.

Brongniart, ${ }^{1}$ Schimper, and other authors use the term Equisetum for the fossil representatives of that genus; as the former has pointed out, there are several species which from the charact $r$ of the fertile as well as the sterile stem structures cannot be separated from the recent genus. So far as we are able to judge, this appears to be the case; but as yet we are in the dark as to the histological structure of the fossil forms, and, with such material as palæobotanists have to deal with, there cannot be any certainty as to the exact connection between the liring and fossil equisetaceous plants. In addition to this necessary imperfection of the fossil material, there is another argument in farour of some slight distinction in the name used for species other than those now in existence, namely the fact that we thus have a convenient distinguishing mark between recent species of Equisetum and their geological representatives.

Owing to the absence of internal structure in the fossil representatives of the Equisetacece our exact knowledge of the ancestral forms of Equisetum leares much to be desired. Graf Solms has called attention to this fact in his "Fossil Botany," 2 and he gives a short critical account of the geological history of the sole surviving genus. A few examples have been recorded from the Coal-Measures of different countries, but as a rule there is very little to be learnt from them. Without attempting any review of the older equisetaceous plants, it is of interest to note that there appears to be some evidence for the existence of this family in Britain during the Coal-Measures period. Kidston ${ }^{3}$ has recently figured and described part of a sporangiferous spike which seems to resemble the fertile apex of a recent Equisetum stem. This new species from the Coal-MLeasures of Yorkshire is named Equisetum Hemingwayi.

1 Brongniart, Tableau, p. 46.

2 p. 175.

3 Annals, vol. ix. ser. vi. 1892, p. 138. A Permian species, E. Tarjolyi, has recently been recorded by Professor Zeiller from Commentry. (Saporta, Rev. gen. bot. vol, v. 1893 , pl. iii. p. 179.) 
So far as facts are arailable, we are warranted in the conclusion that the species of the genus Equisetum, from the Upper Carboniferous period to the present day, appear to have undergone but little change in habit and external appearance; the most striking difference being one of size. In the Triassic period, when Equisetites seems to have reached its maximum derelopment, we find an abundance of rery large stems; from that time the size gradually decreases, and, in the Wealden strata, the few species that are known approach much more nearly in size to the living members of the family.

\section{1.-Equisetites Lyelli, Mantell.}

1833. Equisetum Lyelli, Mantell, Geol. S.E. England, p. 245, figs. 1-3.

1845. Equisetites Lyelli, Unger, Gen. spec. plant. foss. p. 60.

1848. Equisetites Lyelli, Bronn, Index Pal. Nomencl. p. 464.

1849. Equisetum Lyelli, Brongniart, Tableau, p. 107.

1854. Equisetites Lyelli, Morris, Brit. foss. p. 8.

1869. Equisetum Lyelli, Schimper, Trait. pal. vég. vol. i. p. 265, and vol. iii. p. 453.

1871. Equisetum Lyell, Schenk, Palæontographica, vol. xix. p. 207, pl. xxii. figs. 10-13.

1882. Equisetites Lyelli, Renault, Cours bot. foss. vol. ii. p. 150 .

1889. Equisetum Lyelli, Fontaine, Potomac Flora, p. 65, pl. i. fig. 7; pl, ii. figs. 4 and 5.

Type. Small pieces of stem of an arerage thickness of $1.5 \mathrm{~cm}$; internodes about $2.5 \mathrm{~cm}$. in length, the leaf-sheaths dirided into numerous linear acuminate teeth. The surface of the internodes shows faintly marked and numerous longitudinal lines. Single branches at the nodes of frequent occurrence. Sporangia and spores unknown.

The majority of the specimens in the British Mrusenm are pieces of stems showing the leaf-teeth projecting some distance abore each node, and also in a few instances there is a thin brown film on the surface of the internodes. This brown surface layer is all that remains of the plant tissues, and probably is simply the remains of the epidermal layer of cells; it is well shown in specimens V. 59 and V. 2864. 
V. 59. Pl. I. Fig. 5 .

A good specimen, about $12 \mathrm{~cm}$. in length; leares and nodes well shown, also the base of a lateral branch. St. Leonards.

Presented by Mrs. Burnett, 1882.

V. 59 . This small piece is probably the apical bud of a stem or branch. $\quad$ Cf. 3601 . St. Leonards.

Presented by Mrrs. Burnett, 1882.

V. 710. Weli-preserved stem; shows three internodes $2-2.5 \mathrm{~cm}$. in length; leaves distinct. St. Leonards.

Dawson Coll.

V. 2284. Possibly a badly preserved leaf-sheath of E. Lyelli. Ecclesbourne.

Rufford Coll.

V. 2617. Pieces of the larger kind of stem with shorter internodes. $C f$. 8383 , etc. In this specimen the leaves are distinct and appear to agree with those of the $E$. Lyelli type. At one or two of the nodes where the leaf-sheaths are less complete there is a marked resemblance to E. Phillipsii, ${ }^{1}$ Schimper. Cf. also E. lusitanicum, ${ }^{2}$ Heer. Some of these larger examples come very near to the figure of Calamites arenacens minor, Jaeger, ${ }^{3}$ a specios of Equisetites from the Stuttgart sandstone. Sussex.

Beckles Coll.

V. 2730a. Probably the tapering end of a stem showing overlapping leares. $\quad C f$. Mantell's figure ${ }^{4}$ showing a similar tapering stem. Ecclesbourne.

Rufford Coll.

2864. Several specimens with good nodes and leaves; also branch scars. Pounceford, Sussex.

Beckles Coll.

2867. This piece of stem shows five internodes, measuring $10 \mathrm{~cm}$. in length and $1.5 \mathrm{~cm}$. in breadth. One distinct branch scar, with traces of others. Imperfect impressions in some places of the long leaf-teeth. $C f$. Schenk, Palæontographica, vol. xix. pl. xxii. figs. 10-11.

Mantell Coll.

3579. An unusually long piece of a branch attached to the stem.

IIantell Coll.

1 Schenk, Palæontographica, vol. xix. pl. xxii. figs. 6-9.

2 Heer, Secc. Trab. Geol. Portugal, 1881, pl. viii. figs. 1-6.

3 Jaeger, Pflanzenverstein. Stuttgart, pl. vi. fig. 2.

4 Geol. S.E. England, p. 245. 
3582. $12.5 \mathrm{~cm}$. long. Arerage length of internodes $2 \mathrm{~cm}$, breadth $1 \cdot 2 \mathrm{~cm}$.

Mantell Coll.

3591. Badly preserved and crushed stem, shows four and a half internodes. One branch. Cf. Schenk, Palæontographica, vol. xix. pl. xxiv. fig. 12.

Mantell Coll.

3594. Stem showing three nodes, sheathing leares, and one branch.

Mantell Coll.

3598. Small piece, with one node and leaf-tecth particularly well shown, also a branch; almost identical with Schenk's fig. 11, pl. xxii. Palæontographica, vol. xix.

MIantell Coll.

3601. This small specimen may be merely a fragment crushed at one end, but possibly it is the apical termination of a branch. The long linear leaf-teeth are distinctly seen and appear to be closely pressed against the apical bud. Cf. Equisetites Münsteri, Schimp. ${ }^{1}$

IIantell Coll.

8383. Internodes about $2 \cdot 2 \mathrm{~cm}$. long and $2 \cdot 2 \mathrm{~cm}$. broad. This specimen, also $10,847,12,399$ and others, has shorter internodes than most examples of the species; the leaves are less clearly seen, but faintly indicated here and there. There is a distinct similanity, as regards the diameter of the stem and the length of internodes, between such specimens as this and the figure of Equisetites Phillipsii, Schimp., given by Schenk, ${ }^{2}$ but I am unable to fix upon any definite characteristic which would warrant the removal of these larger forms to another species. Pounceford. Jlantell Coll.

12,399. Probably the same species. $14.5 \mathrm{~cm}$. long; leares not clearly defined. Pounceford.

Ilantell Coll.

12.403. Internodes $2.5 \mathrm{~cm}$. in length, $1.8 \mathrm{~cm}$. broad. Imperfectly preserved. Pounceford.

Mantell Coll.

12,406. $11.5 \mathrm{~cm}$. Iong. Impressions in the places of the characteristic leaves. Pounceford.

Mantell Coll.

39,123. $6.5 \mathrm{~cm}$. in length. Crushed and rery imperfect. At two of the nodes there are irregular projections, with their surfaces exhibiting a rough warty appearance; in all probability

1 Schimper, Trait. pal, vég. Atlas, pl. viii. fig. 4.

2 Palæontographica, vol. xix. pl. xxii. 
the result of iron pyrites. At first sight these rough projecting parts remind one of Phyllothece sporangia, but in reality they have no real connection with the stem. Pounceford. Mantell Coll.

The following registered specimens are smaller, or less worthy of note:-V. 2318, Rufford Coll. ; 3575-3578, 3580, 3585-3590, 3592, 3593, 3595-3597, 3599, 3600, 3602-3606, 10,835-10,839, 10,847, 38,375, Mantell Coll.

\section{2.-Equisetites Burchardti, Dunker.}

1824. ? Carpolithus Mantelli, Stokes and Webb, Trans. Geol. Soc. vol, i. ser. ii. p. 423, pl. xlvi. figs. 3 and 4 , and pl. xlvii. fig. 1.

1833. ? Carpolithus Mantelli, Mantell, Geol. S.E. England, p. 245, and fig. p. 246.

1846. Equisetites Burchardti, Dunker, Wealdenbildung, p. 2, pl. v. fig. 7.

1846. Carpolithus cordatus, Dunker, loc. cit. p. 22, pl. ii. figs. 7 and 10.

1846. Carpolithus Huttoni, Dunker, loc cit. p. 22, pl. ii. fig. 8.

1846. Carpolithus Lindleyanus, Dunker, loc. eit. p. 22, pl. ii. fig. 7.

1846. ? Carpolithus Mantelli, Dunker, loc. cit. p. 21, pl. ii. fig. 9.

1848. ? Carpolithus Mantelli, Bronn, Index Pal. Nomencl. p. 239.

1848. Carpolithus Brongniarti, Bronn, loc. cit. p. 239.

1848. Carpolithus cordatus, Bronn, loc. cit. p. 239.

1848. Carpolithus Huttoni, Bronn, loc. cit. p. 239.

1848. Carpolithus Lindleyanus, Bronn, loc. cit. p. 239.

1849. Equisetites Burchardti, Brongniart, Tableau, p. 107.

1850. Equisetites Burchardti, Unger, Gen. spec. plant. foss. p. 59.

1851. Equisetites Burchardti, Ettingshausen, Haidinger Abh. vol. iv. Abth. i. p. 65.

1852. Equisetites Burchardti, Ettingshausen, Abh. k.-k. geol. Reichs. p. 10, pl. i. figs. 3 and 4.

1854. ? Carpolithes Mantelli, Morris, Brit. foss. p. 5.

1869. Equisetites Burchardti, Schimper, Trait. pal. vég. vol. i. p. 264.

1870-72. Cycadinocarpus? cordatus, Schimper, loc. cit. vol. ii. p. 211.

1870-72. Cycadinocarpus? Huttoni, Schimper, loc. cit. vol. ii. p. 210.

1870-72. Cycadinocarpus Lindleyanus, Schimper, loc. cit. vol. ii. p. 240.

1870-72. ? Cycadinocarpus Mantelli, Schimper, loc. cit. vol. ii. p. 211, Atlas, pl. Ixxii. fig. 21.

1871. Equisetites Burehardti, Schenk, Palæontographica, vol. xix. p. 205, pl. xxii. figs. 1-5.

1874. Equisetites Burchardti, Schimper, loc. cit. vol. iii. p. 453.

1878. Equisetites Burchardti, Dixon, Geol. Sussex, edit. iii. p. 282.

1882. Equisetites Burchardti, Renault, Cours bot. foss. vol. ii. p. 151.

1889. Equisetites Burchardti, Bristow, Mem. Geol. Surv. p. 288.

1890. Equisetites Burchardti, Saporta, Compt. Rend. vol, cxi. p. 250. 
Type. Pieces of stem with well-marked dentate sheaths. The species is thus defined by Dunker: "Equisetites caule tenui multiarticulato, striato, striis subacutis viii.- $\mathrm{x}$. aeque distantibus, vaginis tumidis lanceolato-dentatis."

The specimen figured by Dunker has much shorter internodes and more distinct sheathing leares than most of the English examples. Schenk's figures afford a much better idea of the species as represented in the National Collection; long slender internodes with tubers attached to the nodes. The characters shown in Dunker's figures are those of subaerial branches, but most of Schenk's specimens are underground stem structures.

Equisetites Burchardti, Dunk., is chiefly conspicuous by the tubers which occur in large numbers, both isolated and attached to the stem. The oral bodies figured by Stokes and Webb under the name Carpolithus IFantelli have been included by later writers under Dunker's species. In the above list of spnonyms I hare given expression to a feeling of uncertainty as to the correctness of this view; the enlarged drawing given by Stokes and Webb ${ }^{1}$ shows certain characters suggestive of something quite distinct from an Equisetaceous tuber. If their figure be an accurate representation of the fossil, its true position must be regarded as somewhat doubtful. The other species of Carpolithus figured by Dunker are referred to Equisetites Burchardti, with the exception of Carpolithus sertum, ${ }^{2}$ which is probably identical with E. Yokoyame, sp. nov., and $C$. Brongniarti, ${ }^{3}$ which represents a tuber much larger than E. Burchardti, and somewhat different in form. In the figures of $C$. cordatus the slightly cordate tuber is attached to a node of the slender stem of $E$. Burchardti. Dunker's rarious species of Carpolithus were transferred by Schimper to the genus $C y c a d i n o-$ carpus, indicative of Cycadean affinities. In 1871 Schenk figured some examples of Equisetites Burcharlti, which showed conclusively the true nature of most of the various forms of tubers previously classed with fossil fruits. He pointed out how the rariations in size and shape, as represented in Dunker's figures, could be easily explained by the effects of pressure and the manner of preservation. If we examine these figures earefully it appears improbable that

1 Loc. cit. pl. xlvii. fig. 1.

2 Wealdenbildung, p. 22, pl. vii. fig. 3.

3 Ibid. p. 22, pl. ii. figs. 6 and $6 a$. 
they can all be referred to one species; many of them were no doubt unnecessarily separated by Dunker, but in the case of Carpolithus sertum and $C$. Brongniarti we do not recognize the characteristie form of Equisetites Burchariti tubers, nor is it easy to account for the differences by such causes as Schenk has suggested.

In the third edition of Dixon's "Geology of Sussex," Carruthers ${ }^{1}$ suggests that the tubers of $E$. Burchardti from the Isle of Wight may be identical with Mantell's "seed-ressels of Restiacere," described in the "Wonders of Geology," " from the Heathfield ironstone. Schenk ${ }^{3}$ refers to Ettingshausen's figures of Equisetites Burchardti and Carpolithus Lindleyanus as representing respectively a Calamitean branch, and a fragment of Nalchia. The figures of the former appear to me, howerer, to have been correctly named by Ettingshausen; the Carpolithus may be a fragment of Walchia, as Schenk suggests. Fontaine's species, Equisetum virginicum, ${ }^{4}$ from the Potomac beds of America, agrees fairly closely with E. Burchardti.

Although I hare not included in the above synonymy a Japanese species, $E$. Ushimarense, ${ }^{5}$ recently described by Yokoyama from beds which he speaks of as Jurassic, it is by no means certain that his specimens should not be referred to the European species. His description is rery meagre, and the figured specimens not particularly well preserved, but there is an obrious resemblance to E. Burcharlti; this is admitted by Yokoyama, who points to the similarity in the form of the tubers. His short account of the branches agrees with that given by Schenk for the North German specimens, e.g. ef. Yokoyama's fig. 3, pl. xi. and Schenk, pl. xxii. fig. 1. In spite of the close resemblance, it is probably better to retain Yokoyama's new name; the slight difference in shape is not of great specific ralue, but it is the chief feature afforded by the imperfect materials. Further discoveries in the Japanese plant beds may establish a specific distinction on a firmer basis, or, on the other hand, may afford stronger evidence of specific identity.

1 p. 282.

2 Edit. iii. p. 372.

3 Palæontographica, p. 206.

4 Potomac Flora, p. 63.

5 Journ. Coll. Sci. Japan, vol, iii. 1890, p. 39, pl, xi. figs, 1-3. 
Tubers of Equisetum and Equisetites.-In Dural-Joure's Monograph on the French species of Equisetum some good figures are given, which have been repeatedly reproduced by subsequent writers, showing the nature and manner of occurrence of tubers. On pl. i. fig. $4,{ }^{1}$ is represented a node of a rhizome of Equisetum maximum, Lam., from which three sets of pyriform tubers are giren off; fig. 1 of the same plate shows elliptical tubers attached to a rhizome of $E$. arvense, L., and in fig. 5 the tuherous branches of $E$. palustre, L. These tubers occur either singly, or sereral together, in the form of a string of beads, and are simply internodes of rhizome branches which have been specially modified to serre as reservoirs of food material. The internal tissues hare increased enormously in bulk, and, at the expense of growth in length, the internodes have become tuberous, with their parenchymatous cells rich in starch. At the base of each tuber the dentate leaf-sheath is easily seen, and if the end tuber of a chain be removed the sheath remains attached to the tuberous internode next below in the form of an apical crown. Frequently the tubers are wrinkled on the outside, and, where an axial carity is present, this surface-wrinkling may be very pronounced. These special internodal structures, after passing through a period of rest, are able to grow into new Equisetum plants, and thus serve the purpose of regetative reproduction.

Among recent "Horsetails" they occur more or less frequently in such species as E. arvense, L., E. syluaticum, L., E. Telmateia, Ehrh., etc. According to Dural-Jouve, Equisetum tubers were first noticed by Helwing in 1712, and are thus described by him in E. arvense: ${ }^{2}$ " Hujus radicibus glandes copiose adhurent, et quam maxime in agris arenosis effodiuntur a suibus et pueris rusticis. Grati et dulcis sunt saporis. Instinctu nature sues odoratu superficiem terre delegunt, et tam diu terram evolvunt, quoad appropinquent ad glandes, Polonice Geguzie, nostratibus 'Erd-Nïsse' dictos, quod subulci animadvertentes statim accurrunt, et pedibus porcos abigentes leviosimo labore nucleos suos terrestres colligunt. Maturesount circa tempora autumni."

In 1768 Alberti V. Haller briefly refers to the same bodies as

1 Hist. Nat. Equisetum.

2 Helwing, Fl. Plant. indig. Pruss. p. 31. 
follows :- "Radicibus tamen glandium simile oliquid sape adhoret, quot porcos credas requirere." De Candolle in his "Flore Française" " describes a new species, $E$. tuberosum, previously proposed by Hectot, and specially characterized by the formation of tubers on the lower nodes. In 1828 Bischoff $^{3}$ figured the tubers of $E$. arense attached to the rhizome. Among more recent authors, in addition to Dural-Joure, Milde ${ }^{4}$ gires figures of tubers attached to $E$. hiemale, L.

Such tuberous internodes seem to have been unusually numerous on the rhizome of Equisetites Burchardti, as is clearly shown by the large numbers of attached and separate tubers in the English Wealden beds. No other species of Equisetites affords such numerous examples of tubers as this Wealden form, but a Tertiary species, Equisetites Parlatorii, Heer, ${ }^{5}$ should also be quoted as characterized by its chains of elliptical tubers. Heer originally described this species as Physagenia Parlatorii, ${ }^{6}$ from Switzerland, and recognized a probable relationship to $E$. Burchardti; he included it, howerer, among the "Plantae incerta sedis," and, at the same time, compared the "bladders" to the tubers of Equisetum arrense, L., and other species. Schimper afterwards changed Heer's name, Physagenia Parlatorii to Equisetum Parlatorii. ${ }^{7}$ Another instance of fossil tubers is recorded by Heer from the Jurassic beds of Amur, ${ }^{8}$ under the name Equisetum Burejense, Heer, and compared by him to the Wealden Equisetites Burchardti. The same author has recorded another species with tubers, $E$. areticum, Heer, from the "Miocene" of Spitzbergen. ${ }^{9}$ The gigantic Triassic Equisetites appear to have produced correspondingly large tubers, e.g. E. arenaceum, Jaeg., and E. Mrïnsteri, Sternb. ${ }^{10}$

1 Hist. Stirp. indig. Helret. vol. iii. p. 2 (under No. 1677, not 1676 as stated by Duval-Jouve).

2 Vol. v. p. 245.

3 Die Chareen und Equiseteen, pl. iv. fig. 6.

4 Mon. Equiset. pl. xxix. Nova Acta Ac. Cæs. Leop.-Car. 1865, vol. xxxii.

5 Heer, Fl. Tert. Helvet. vol. iii. p. 158, pl. cxlv. figs. 17-18.

6 Ibid. vol. i. p. 109, pl. xlii. figs. 2-17.

7 Trait. pal. vég. vol. i. p. 261.

8 Fl. foss. Arct. vol. iv. p. 99, pl. xxii. figs. 6-7.

9 Ibid. vol. ii. pl. i. figs 1-15.

10 Schimper, Trait. pal. vég. Atlas, pls. ix.-xi. 
V. 2367. Pl. I. Figs. 5 and 6.

This specimen shows rery clearly the nature of the tuber and the dentate leaf. A delicate branched root occurs immediately below the node to which the tuber is attached. At the apex of the tuber the pointed teeth of the leaf-sheath are easily seen. Cf. Schenk, Palæontographica, vol. xix. p. 206, pl. xxii. fig. $5 a$; also Duval-Jouve, Hist. Nat. Equisetum, pl. i. fig. 5.

The fragment at the upper corner of the same piece of rock, represented in Fin. 6, shows part of another tuber, also three delicate linear acuminate teeth; the stem is traversed by two distinct grooves.

Fig. 5 suggests the natural position of growth of the underground axis with its tuberous branch and branched root. Bexhill. Rufford Coll.

V. $10 \% 0$. Slender and imperfectly preserved stem, $23.5 \mathrm{~cm}$. long. Several casts of tubers. Cf. Schenk, Palæontographica, vol. xix. pl. xxii. fig. 1.

V. 1070 and V. $1070 a$. A short piece of stem with three tubers, and another piece with four.

V. $1070 b$. Fragments of stems and several tubers. Two tubers shown in contact. Near Hastings.

Presented by P. Rufford, Esq., 1885.

V. 2256. Three tubers, broadly oval in shape; the surface and the clay casts covered with a thin black film. Bexhill.

Rufford Coll.

V. $2730 a$. Fragments of stems showing longitudinal ridges.

V. $2730 b$. Narrow curved stem $20 \mathrm{~cm}$. long; long internodes, $2-3.5 \mathrm{~cm}$. in length. On the same specimen occur several globular and elliptical tubers, about $1.5 \mathrm{~cm}$. in length. Bexhill.

Rufford Coll.

V. 2739. This specimen shows the basal end of a tuber with a central depression. Bexhill.

Rufford Coll.

V. 2834. Several tubers of smaller size, but similar in form to the larger examples of this species. $C f$. Dunker, Wealdenbildung, pl. ii. fig. 10. Bexhill.

Rufford Coll.

V. 2818 and V. 2819. Fragment of the same species. Bexhill. Rufford Coll. 


\section{3.-Equisetites Yokoyamæ, sp. nor.}

1816. ? Carpolithus sertum, Dunker, Wealdenbildung, p. 22, pl. vii. fig. 3.

1875. Equisetites Burcharlti (in part), Schenk, Palæontographica, vol. xxiii, p. 157, pl. xxvi. fig. 1.

Type. Tubers and fragments of stems from Ecclesbourne, near Hastings. British Museum. Woodcuts, Figs. 2, 3 and $3 *$.

Stem narrow, internodes about $1.1 \mathrm{~cm}$. in length and $5 \mathrm{~mm}$. in breadth; tubers narrowly elliptical, attached singly or in chains to the nodes.

In the National Collection there are several specimens of Equisetaceous tubers, both isolated and attached to stems, which are distinct in shape from those of E. Burchardti, Sehimp. Mr. Rufford informs me that these two kinds of tubers never occur together, the specimens of the latter species being found at Bexhill, those of the other type at Ecclesbourne. I have decided, therefore, to give expression to the distinctive character of the Ecclesbourne tubers, and have named the new species after Dr. Yokoyama of Tokyo, who has in recent years made valuable additions to our knowledge of the Mesozoic floras of Japan.

In $E$. Yokoyame there are very few details of structure shown in the sandstone specimens. The stems are usually in the form of smooth slender casts with little or no indication of longitudinal ribs and grooves, or leaf-sheaths; the tubers differ from those of $E$. Burchardti in their smaller size and narrower elliptical form.

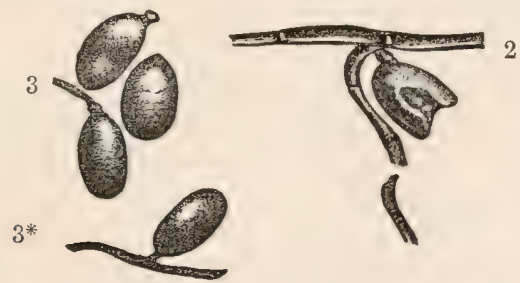

Fig 2 (V. 2871). Fig. 3 (V. 2871). Fig. $3^{*}$ (V. 2335).

Tubers of Equisetites Yokoyama, sp. nov.

One of the best examples is represented in Fig. 2; part of a shrunken tuber is shown in place, and immediately below it is a branch attached to the node. This example, with several others, has probably been preserved in the sandy soil in its original position of growth. 
In Figs. 3 and $3^{*}$ we have examples of more perfect tubers. The tubers figured by Dunker under the name Carpolithus sertum agree very closely with some of the English specimens; but the absence of any definition of the North German species prevents us adopting Dunker's name, eren if we regard his specimens as identical with ours.

In his second Memoir on the Wealden Flora, Schenk has figured a specimen with numerous tubers under the name Equisetites Burchardti, Dunk.; this seems, however, to have a closer resemblance to our new species; the tubers are narrow and less spherical than those of $E$. Burchardti. If we compare Schenl's fig. 1, pl. xxii. Palæontographica, rol. xix. and fig. 1, pl. xxvi. Palæontographica, vol. xxiii. we notice a distinct difference, not only in the shape of the tubers, but in the general habit of the tuber-bearing plant. Schenk's latter figure shows some of the tubers juined end to end; the same kind of arrangement occurs in some of the English examples, e.g. V. 2365a. It is, perhaps, not entirely satisfactory to hare to rely upon certain differences in the shape of tuberous internodes in determining specific definitions; but in the present instance the arailable material appears to show well-defined differences, and there is confirmatory eridence in the fact that the two forms of tubers are never found in close association.

V. 2871. Fig. 2. Internodes 1-1.2 cm. long, about $2 \mathrm{~mm}$. broad. The sindstone matrix is penetrated by stems and root fragments; portions of tubers. Cf. E. Burchardti, Dunk., pl. i. fig. 5. Ecclesbourne.

Beckiles Coll.

V. 2871. Fig. 3. A few well-preserved tubers; two shown in place at one node; fragments of roots. Nodes not clearly marked, no ribs on the internodes, the latter about $1 \mathrm{~cm}$. in length. Ecclesbourne.

Beckles Coll.

V. 2335. Fig. $3^{\text {* }}$, p. 33 . Numerous tubers, some attached to the slender stem. Ecclesbourne. Rufford Coll.

V. 727. Several tubers, with stem fragments; many of the former show surface depressions due to shrinkage of the tuber tissues. Ecclesbourne.

Dawson Coll.

V. 2365. Five specimens. To detail shown. Ecclesbourne. Rufford Coll. 
V. 2365 $a$. Tro long and narrow tubers joined together. Cf. Dunker, Wealdenbildung, pl. vii. fig. 3 ; also Schenk, Palæontographica, vol. xxiii. pl. xxri. fig. 1, and Heer, F1. Tert. Helret. vol. iii. pl. cxlv. Ecclesbourne.

Rufford Coll.

V. 2700. Very thin stem, $1 \mathrm{~mm}$. broad and $8 \mathrm{~cm}$. long; matrix penetrated by roots. Ecclesbourne.

Rufford Coll.

V. 2833 and V. 2834. Several tubers of the characteristic shape. Ecclesbourne.

Rutford Coll.

\section{Class FILICIN $\nexists$.}

Leares large in proportion to the stem. Sporangia usually occur on the margins or lower surface of ordinary leares; occasionally the fertile leares are distinguished from the sterile by wellmarked characters.

\section{Sub-Class FILICES.}

Isosporous plants. The prothallus (gametophyte generation) usually monœcious, of moderately large size, and capable of an independent existence. The sporangia usually occur in definite groups or sori, with or without indusia.

\section{INTRODUCTION TO FILICES.}

Probably no fossil plants are more widely known than the fragments of fern fronds so abundant in the beds of shale associated with our Coal-Measures.

When we come to inquire how far palæobotany has made us intimately acquainted with the general morphology, the minute histology, and the natural affinities of the Coal-Measure ferns, it must be admitted that our scientific knowledge of them is extremely limited. There are certain forms of Palæozoic ferns, and in the Mesozoic floras there are also a few genera, of which it is possible to speak with confidence as to family, and occasionally as to internal structure; but such cases are exceptional. The old generic names such as Pecopteris, Sphenopteris, Neuropteris, and others, were instituted as convenient terms by which to 
distinguish certain types of fern fronds, separated from one another by the characters of their nervation; these have been, and still are to a large extent, the accepted terms which are used in speaking of Palæozoic specimens. They are accepted on the understanding that in making use of such names we are merely admitting our imperfect knowledge, and, as the only possible basis of classification, make use of a system which is thoroughly artificial. Ettingshausen, whose works on the venation of the regetative organs of plants are so widely known, attempted a classification of living ferns on the same lines as those which are followed in dealing with fossils. ${ }^{1}$ That such a system of arrangement rests on a foundation utterly insecure has been pointed out by Stur in his classic work on "Die Carbon-Flora der Schatzlarer Schichten." ${ }^{2}$ He shows how such a genus as Polypodium affords examples of eleven of Ettingshausen's venation types, and how the same genus has three types in common with Acrostichum, four with Pteris, four with Asplenium, and six with Aspidium. Then again the renation type Sphenopteris occurs in twelve genera and three families. Hence it must be admitted that the genera which are based on characters of venation alone are essentially provisional, and, if recognized as such, are of extreme value until increased knowledge places us in a position to determine the family to which a fossil fern belongs.

The custom of giving recent generic names to fossil ferns is one which several writers have frequently adopted in dealing with Mesozoic and Tertiary plants. This practice, I am inclined to think, has been followed too commonly; and the result has been that among the more modern fossil ferns we find a large number of species spoken of by the names of living genera, to which they hare little or no claim to relationship. In speaking of fossil alga attention has been drawn to the great danger which necessarily accompanies this use of modern names; the same remarks apply in the present instance with equal weight. Surely there ought to be good evidence at our command before a fossil fern is designated by such names as Dicksonia, Thyrsopteris, Aspidium, etc., and thus presumably an authenticated occurrence put on record of any of these genera at a certain locality and

1. Farnkrt. Jetztwelt. Vienna, 1865.

2 Abh. k.-k. geol. Reichs. vol. xl. Abth. i. 1885. 
geological horizon. The termination "ites," or some similar widely adopted ending, is in some degree a safeguard; it at least shows at once that the species is a fossil, and not a recent fern, and, therefore, as experience has taught, to be accepted cautiously.

To retain all the old names in spite of adrance in scientific knowledge would be at once a want of recognition of palæobotanical progress, and a serious obstacle to phylogenetic investigations. The better plan, and one less likely to add unsound links in the chain of eridence on which genealogical diagrams are attempted, would be to retain the older system of nomenclature, proposed by Brongniart and added to or modified by subsequent writers, until such specimens are forthcoming which supply us with fertile fronds or pinnæ, and thus render possible a comparison with recent forms based on a surer foundation.

In Hooker's well-known paper "On the Vegetation of the Carboniferous Period, as compared with that of the present day," 1 the difficulties of determining fossil ferns are brought home in a clear and striking manner by one well qualified to speak on the characters of recent ferns. Many of these difficulties are recognized by all who have even the most superficial acquaintance with palæobotanical herbaria, but it is probable that had more attention been paid to Hooker's valuable cautions our lists of synonjms would not have reached that length and variety which they too frequently show.

There are a number of fossil ferns from rocks of different ages, named neither on account of their renation nor fructification characters, but on certain morphological characteristics which are easily recognized and typical of some peculiar modern genera. No doubt such a basis for a generic title may often be trustworthy, and exceedingly useful as a means of arriving within measurable distance of natural affinity. In such cases, therefore, where we have striking morphological features to guide us, we may with advantage make use of them without waiting for the further evidence of sori or sporangia.

In the works of Stur ${ }^{2}$ and Zeiller ${ }^{3}$ on Carboniferous ferns we have admirable proofs of the better material which palæobotanists

1 Mem. Geol. Surv. vol. ii. pt. ii. 1848.

2 Loc. cit.

3 Bassin Houiller de Valenciennes. 
have at their disposal to-day, as compared to that which was accessible to earlier workers. In the writings of these authors many of the provisional and artificial terms are replaced by new generic names of real taxonomic value, and resting on such a basis as would be recognized as reasonable by modern botanists.

In working through the specimens of ferns mentioned in the present Catalogue the difficulty of coming to satisfactory conclusions as to limits of specific distinctions, and the claim of isolated frugments to be included in one or other genus or species, has been demonstrated with only too much clearness. It is impossible to deny that many of our fossil species. determined by those much more fully equipped with the requisite knowledge and experience than myself, are of very loubtful value. Granting the truth of this assertion, it must be remembered that specific distinctions and definitions are of very great importance in fossil botans, and if we waited until our hands were full of all the needful data we should never make any appreciable advance in the analysis of geologic Horas. We must recognize that the numerous species of fossil plants do not all rest on unequivocal foundations; but they are at all events not quite so meaningless and unscientific as some would lead us to believe.

The Wealden material affords many interesting examples of the importance of bearing in mind the great differences in species which are solely due to the manner of preservation, and the character of the matrix in which the fossils are found. Some of the fragments, marked out in clear dark-brown lines on a fine homogeneous stone, present a very different appearance when scen as carbonaceous impressions on the surface of a grey-coloured clay. Again, such characters as the shape of the pinnules, whether acutely terminated or with obtuse apices, whether with entire margins or slightly dentute, are to be used with extreme care in view of the different forms which appear in the ultimate segments of recent fronds, according as they are fresh and flat, or dry and more or less curled over at the edges. The position of the pinnie on the main rachis, whether alternate or opposite, is of little ralue in the case of fragmentary remains; in recent fronds the pinno may be opposite towards one end of the rachis, and distinctly alternate towards the other. Another character which I am disposed to regard as of little value is the relative size of the fronds, and also the size of the ultimate dirisions. Probably the 
specimens placed together under Ruffordia Göpperti (Dunk.), as shown in Pls. III.-V., will be regarded by some as obriously listinct; such, indeed, they may prore to be, but at present I am unable to draw any line between the various types which seem to pass gradually one into another without any appreciable break. To class such leaves together among living ferns would not be considered an unwarranted step in the case of certain species; if, therefore, such a course is adopted in dealing with fossil ferns there can be no very serious argument adranced against it.

In a recent volume of Engler's "Botanische Jahrbücher," we hare an interesting account by Raciborski of a Mesozoic fern flora from Jurassic rocks in the neighbourhood of Cracow. ${ }^{1}$ He has made good use of the specimens of fern sporophylls at his disposal, and from the character of the sori and sporangia he has been able to refer many species to their natural position. The genus $K$ lukia is proposed by this writer for the reception of some widely-spread species which possess sporangia of the same type as those of the recent Schizacere. Such a resemblance to Schizacere was first pointed out by Bunbury ${ }^{2}$ in Pecopteris exilis, Phill., from the Yorkshire coast; this species he referred to a position near to Anemia and Mohria. Researches such as this are of the greatest value, and by instituting new names like the one proposed by Raciborski, we are remoring the plants from a purely artificial designation to a place in the same category as recent ferns, where the generic and specific titles are professedly based on accepted and trustworthy characters. In the following descriptions of Wealden Filices, the acquisition of a considerable amount of fresh material, thanks mainly to the labours of Mr. Rufford, has enabled us to arrive at certain conclusions as to the systematic position of plants hitherto known under provisional names. The transference of Sphenopteris Mantelli, Brong., to Onychiopsis Mantelli (Brong.), is an instance of this; and in the case of the Wealden species, Sphenopteris Gopperti, Dunk., there is evidence at hand which renders the employment of a new generic designation an advisable step. In both these instances I hare mentioned, the change of name, and the reference to certain families of ferns, are based

I Bot. Jahrb, vol. xiii. p. 1, 1891.

2 Quart. Journ. Geol. Soc. vol. vii. 1851, p. 188, pl. xiii. figs. $5 a$ and $5 b$. An examination of Bunbury's specimen (Botanical Museum, Cambridge), enables me to confirm the reference to Schizacece. 
on the general character of the fructification, and not on details of sporangial structure. Unfortunately no sporangia are sufficiently clearly preserved to afford that important assistance which a more intimate knowledge of them would give. It is to be regretted that the material from the English Wealden does not often enable us to learn anything as to histological structure. There is, howerer, a notable exception in Tempsliya Schimperi, Corda, in which structural details hare often been more or less clearly mineralized, thus enabling us to add something towards the elucidation of the real botanical position of this remarkable fossil.

\section{A. Genera assigned to existing Families.}

\section{Order LEPTOSPORANGIAT AE.}

The Sporangia, with walls composed of a single layer of cells, are developed from single surface cells.

\section{Family POLYPODIACE无.}

Sporangia stalked, and with a vertical incomplete annulus.

\section{Genus ONYCHIOPSIS, Yokoyama.}

[Journ. Coll. Sci. Japan, vol. iii. 1890, p. 26.]

Frond tripinnate, main rachis slender, may be winged, pinnæ alternate, approximate, lanceolate. Pinnules narrow, lanceolate, acute, alternate, the larger ones serrate, and gradually passing into pinnules with narrow ultimate segments. Fertile pinnæe with alternate elliptical pinnules which differ in shape from the sterile pinnules, and have the sporangia on the lower surface, giving them the appearance of raised elliptical bodies.

This genus was instituted by Yokoyana for the reception of a Japanese species, originally described by Geyler ${ }^{1}$ as Thyrsopteris elongata, and afterwards referred to by Yokoyama as Dicksonia elongate. The occurrence of fertile pinnules of a distinct and unusual type led to the remoral of the specimens from Thyrsopteris to Onychiopsis. Yokoyama pointed out the resemblance between the fertile pinnæ of the Japanese specimens and those of the

1 Palseontographica, rol. xxiv. 1876-77, p. 224, pl. xxxi. fig. 4. 
recent genera Onychium and Gymnogramme, especially of the former. The original diagnosis of the genus Onychiopsis, with reference to a single species, $O$. elongata, is as follows ${ }^{2}$ :-

"Fertile segments different from the sterile. Sori terminal, linear, on each side of the midrib, parallel with the margin, incolucrate; the involuerum of each side confluent over the midrib."

So far as I have been able to discover, this is the first record of Onychium among fossil ferns. According to the "Synopsis Filicum," the genus occurs at the present time in Northern India, China, Japan, Java, Persia, Abyssinia, and Malayan Peninsula and Islands, etc.

The more detailed examination of the points of agreement between the fossil species and the living genus will be attempted in the description of the two species Onychiopsis elongata (Geyl.) and 0 . Mantelli (Brong.).

\section{1.-Onychiopsis Mantelli (Brongniart).}

1824. Hymenopteris psilotoides, Stokes and Webb, Trans. Geol. Soc. ser. ii. vol. i. p. 423 , pl. xlvi. fig. 7 .

1825. Hymenopteris psilotoides, Sternberg, Flor. Vorwelt. iv. p. xxii.

1827. Hymenopteris psilotuides, Mantell, Illust. Geol. Sussex, p. 55, pl. i. $3 a$ and $3 b$; pl. iii. fig. 6 ? and 7 ; pl. iii.* fig. 2 .

1828. Sphenopteris Mantelli, Brongniart, Prodrome, p. 50. Sphenopteris Mantelli, Brongniart, Hist. vég. foss. p. 170, pl. xlv. figs. $3-7$.

1833. Sphenopteris Mantelli, Mantell, Geol. S.E. England, p. 241.

1833. 'Sphenopteris Sillimani, Mantell, Geol. S.E. England, p. 239.

1836. Cheilanthites Mantelli, Göppert, Foss. Farnkrt. p. 231, Nova Acta Ac. Caes. Leop.-Car. vol. xvii. Supp.

1838. Sphenopteris Mantelli, Sternberg, Flor. Vorwelt. vii. p. 56.

1839. Cheilanthites denticulatus, Roemer, Verstein. Ool.-Geb. p. 9, pl. xrii. fig. 1.

1843. Cheilanthes (Sphenopteris) Mrantelli, Dunker, Progr. p. 5.

1845. Sphenopteris Mantelli, Unger, Syn. plant. foss. p. 59.

1846. Sphenopteris Mantelli, Dunker, Wealdenbildung, p. 2, pl. i. fig. $4 a$.

1846. Sphenopteris Römeri, Dunker, loc. cit. p. 3, pl. i. figs. 3, 4 and 5.

1846. Sphenopteris tenera, Dunker, loc. cit. pl. viii. fig. 5 .

1846. Confervites fissus, Dunker, loc, cit. pl. i. fig. 1.

1848. Sphenopteris Mantelli, Bronn, Index Pal. Nomenel, p. 1169.

I Yokoyama, loc. cit. p. 26.

2 Hooker and Baker, p. 143. 
1848. ? Sphenopteris Sillimani, Bronn, Index Pal. Nomencl. p. 1170.

1850. Sphenopteris Mantelli, Unger, Gen spec. plant. foss. p. 108.

1851-52. Sphenopteris Mantelli, Bronn, Leth. geog. vol. ii. p. 49, pl. xxviii. fig. $4 a b$.

1852. Sphenopteris Mantelli, Ettingshausen, Abh. k.-k. geol. Reichs. p. 14, pl. iv. figs. 3 and 4.

1854. Sphenopteris Mantelli, Morris, Brit. foss. p. 21.

? Sphenopteris Sillimani, Morris, loc. cit. p. 21.

1865. Microlepia Mantelli, Ettingshausen, Farnkrt. Jetztwelt, p. 216.

1867. Sphenopteris antipodum, Tate, Quart. Journ. Geol. Soc. vol. xxiii. p. 139.

1869. Splenopteris (Davallioides) Mantelli, Schimper, Trait. pal. rér. vol. i. p. 393.

1871. Sphenopteris Mantelli, Schenk, Palæontographica, rol. xix. p. 208, pl. xxiii. figs, 1-8.

1871. Sphenolepis Kurriana, Schenk, pl. xxv. fig. 6, loc. cit. p. 243, pl. xxxviii. fig. 2.

1871. Sphenopteris Göpprerti, Schenk (in part), loc. cit. pl. xxv. figs. 3 and $3 a$. (Not the other figures of this species.)

1874. Sphenopteris Mantelli, Schimper, Trait. pal, vég. vol. iii. p. 469.

1875. Sphenopteris Mtuntelli, Schenk, Palieontographica, vol. xxiii. p. 158, pl. xxviii. fig. 12 .

1878. Sphenopteris Roemeri, Dupont, Bull. Ac. R. Belg. vol. xlvi. ser. ii. p. 396.

1851. Sphenopteris Mantelli, Heer, Sece. Trab. Geol. Portugal, 1881, p. 12, pl. xi. figs. 1-5, pl. xii. figs. $2 b$ and $2 b b$.

1881. Sphenopteris valdensis, Heer, loc. cit. p. 14, pl. xv. figs. 9, 10 and 13, pl. xvi. fig. 5b. (The other figures more doubtful.)

1883. ? Trichomanites laxum, Tenison-Woods, Proc. Linn. Soc. N. S. Wales, vol. viii. pt. i. p. 95, pl. x. fig. 2.

1883. ? Trichomanites spinifolium, T'nison-Woods, ibin. p. 95, pl. iii. fig. 7. 1889. Sphenopteris IIantelli, Fontaine, Potomac Flora, p. 91, pl. 1. figs. 1 and 2.

1890. Sphenopteris Mantelli, Nathorst, Denkseh. k. Ak. Wiss. math.-nat. Cl. vol. 1vii. p. 55 (referred to Onychium).

1891. Sphenopteris Mantelli, Saporta, Compt. Rend. cxiii. p. 250.

1891. Sphenopleris Jiantelli, Engelhardt, Abh. Isis. Dresden, p. 79.

1892. ? Trichomanites laxum, Jack and Etheridge, Geol. Pal. Queensland and New Guinea, p. 315 , pl. xviii. fig. 9.

Type. Portions of pinnæ.

The type specimen was originally figured by Stokes and Webb in an anonymous paper which appeared in the Transactions of the Geological Society for 1824. $\quad$ These authors hesitated to pronounce a decided opinion on the affinity of the plant, but recognized that

1 Trans. Geol. Soc. ser. ii. vol. i. p. 421. 
it would "probably be a Sphenopteris" in the system of Brongniart. They proposed the name Hymenopteris psilotoides. The same figure reappears in Mantell's "Illustrations of the Geology of Sussex" under the original name. The species Sphenopteris Mantelli is first mentioned by Mantell $^{1}$ in a quotation from a letter received by him from Brongniart, who proposed that the name Hymenopteris psilotoides should be replaced by the more suitable designation Sphenopteris Mantelli.

Brongniart ${ }^{2}$ includes the species in his Prodrome, and gives the first diagnosis in the Histoire ${ }^{3}:-$

"S. foliis bipinnatifidis, pinnis approximatis virgatis fastigiatis, pinnulis obliquis, omnibus integris uninerviis, angustis, cuneatis, apice oblique truncatis et subemarginatis; parte exteriori longius producta."

Since 1828 different writers have added to or variously modified Brongniart's definition; without quoting any of these we may substitute a definition of the species founded on the exceedingly good material in the National Collection.

Frond tripinnate, ovate lanceolate, rachis winged and prominent; pinnæ lanceolate, alternate, approximate, given off from the main rachis at an acute angle. Pinnules alternate, narrow, lanceolate acuminate, uninerved, of nervation t5pe Coenopteridis; ${ }^{*}$ the larger ones serrate and gradually passing into pinnæe with narrow ultimate se'gments.

Fructification in the form of sessile or shortly stalked linear orate segments with rugose surfaces, and terminating usually in a very short awn-like apical prolongation.

The specimen figured by Wantell in $1827^{5}$ (pl. iii. fig. 6) may belong to this species, but the figure represents a number of detached fragments which it is impossible to refer with much certainty to any species. Mantell's Sphenopteris Sillimani ${ }^{6}$ is rery possibly a bally preserved piece of an Onychiopsis MLantelli frond. Carruthers, ${ }^{7}$ in his account of the Cretaceous plants in Dixon's

1 Illust. Geol. Sussex, p. 55.

2 Prodrome, p. 50.

3 Hist. vég. foss. p. 170.

4 Luerssen, in Rabenhorst's Krypt. Flora, vol. iii. p. 11.

5 Illust. Geol. Sussex.

6 Geol. S.E. England, p. 239.

7 Geol. Sussex, p. 282. 
"Geology of Sussex," refers to the method of branching in $S$. Sillimani as unlike that of ferns, but suggests it may possibly be the skeleton of part of a frond. It is true that Mantell's specimen does not by any means closely resemble a typical Onychiopsis Mantelli fragment, but it agrees fairly well with some of the more fragmentary and less defined specimens. Schenk ${ }^{1}$ decides to regard Confervites fissus, Dunker, as a fragment of 0 . Mantelli, and is led to this conclusion from an examination of Dunker's type specimen. There is no appreciable difference between Dunker's figure of this supposed alga and Mintell's Sphenopteris Sillimani; it would seem, therefore, that the best course to follow is to regard both names as synonyms of Onychiopsis Mantelli.

With regard to the species of Sphenopteris, S. Römeri and S. tenera, figured by Dunker, there can be little or no doubt that previous writers hare correctly included them under Brongniart's characteristic Wealden species.

The species of Sphenopteris described and figured by Tate from the Geelhoutboon beds in the Uitenhage series of South Africa has not hitherto been compared to O. Mantelli. This South African form is compared by Tate ${ }^{2}$ to Sphenopteris Jugleri, Ettingshausen (written in Tate's paper "Fulgeri"), a species included in this Catalogue under Ruffordia Göpperti (Dunk.). There is such an obrious resemblance between $S$. antipodium and some of the pieces of 0 . Mantelli fronds from the Ecclesbourne beds, that it is impossible to point to any difference which would warrant the retention of Tate's name. After looking at Tate's type specimen in the MIuseum of the Geological Society, Burlington House (41J. Foreign Coll.), I have no hesitation in regarding it as an example of 0 . Mantelli. In the National Collection there are a few specimens of this plant from Africa, e.g. V. 2399 and V. 2401. In the descriptions and illustrations of North German specimens Schenk has added considerably to our know. ledge of this species, but he failed to recognize the fact, since pointed out by Nathorst, that one of his figured specimens of Sphenolepis Turriana, Schenk, ${ }^{3}$ is in reality part of a fertile frond of $O$. Mantelli. One of the specimens figured by Schenk ${ }^{4}$ as

1 Palicontographica, vol. xix. p. 209.

2 Quart. Journ. Geol. Soc. vol. xxiii. 1867, p. 139, pl. vi. fig. 3.

3 Palæontographica, vol. xix. pl. xxxviii. fig. 2.

4 Loc. cit. pl. xsv. fig. 3. 
S. Göpperti is most probably a piece of a pinna of 0 . Mantelli. I have little doubt that the specimens figured by Heer from Almargem, Portugal, as Sphenopteris valdensis are fragments of O. Mantelli; they correspond very closely with the coarser pinnx of the latter species. Cf. e.g. Heer's figs. 9 and 10, pl. $x \nabla .{ }^{1}$ with the large frond from Ecclesbourne, Pl. II. Fig. 1. Possibly fig. 11 of Heer represents another species, Ruffordia Göpperti.

In 1883 Tenison-Woods ${ }^{2}$ published an account of the fossil flora of the Coal deposits of Australia ; in his list of ferns are included two new species, Trichomanites laxum and $T$. spinifolium, both of which, so far as it is possible to judge from the poor figures, may in all probability be referred to Onychiopsis Mantelli.

Messrs Jack and Etheridge, in their recent work on "The Geology and Palæontology of Queensland and New Guinea," " have referred a fern from the Burrum beds of Queensland to TenisonWoods' species, $T$. laxum; the figure of this plant leads me to refer it, with rery little hesitation, to the characteristic species of the European Wealden beds. The age of the Burrum beds is not precisely defined; "newer than the Permo-Carboniferous, and older than the Upper Cretaceous." 4

Fontaine, in his Monograph on the Potomac Flora, has instituted several new species of Kunze's isolated genus Thyrsopteris. On examining his figures of the various types, one cannot help feeling that the grounds on which the genus has been chosen are somewhat insufficient. After speaking of Heer's description of Thyrsopteris, he notes a close resemblance between some of the Potomac forms and the sterile fronds of Kunze's genus, and goes on to say: ${ }^{5}$ "These (i.e. the Potomac specimens) I place provisionally in the genus Thyrsopteris, on account of the great resemblance that the shape of the pinnules, the lobing, and the nerration show to the sterile forms of the various species determined to be Thyrsopteris by their fructification. As, however, no fructification is found in the Potomac species, the placing of these plants in the genus must be regarded as provisional." Finally, we read: "It should be noted that a number of the species of Thyrso-

1 Secc. Trab. Geol. Portugal, 1881.

2 Proc. Linn. Soc. N. S. Wales, vol. viii. pt. i. 1883, p. 37.

I Ibid. p. 315.

4 Ibid. p. 301.

5 Potomac Flora, p. 120. 
pteris described in the following pages show a good many features similar to those of Sphenopteris MYuntelli, as described by Schenk and Heer." In his deseription of T. rarinervis, Fontaine speaks of his new species as " "one of the Sphenopteris Mantelli type, and perhaps by some would be united with that species, but it is more robust, and the pinnules are more like those of the Thyrsopteris type." Again, in describing $T$. insignis and $T$. insignis, var. angustipennis, the same author adds that both represent plants belonging to the $S$. Wantelli type. ${ }^{2}$ From an examination of Fontaine's figures of the various species of Thyrsopteris, it is difficult in some cases to thoroughly appreciate those characteristics which have served to separate the closely allied forms.

In discussing "S. Mantelli," Fontaine refers to its polymorphous nature, and prefers to include several plants of the Mantelli type under the genus Thyrsopteris. Except in cases where the fructification has been preserved it is questionable whether the better course would not be to retain the old name, and not introduce new ones without trustworthy evidence. Fortunately some of the specimens recently acquired by the British Museum show distinct fertile segments, and thus enable us to refer the species with some degree of certainty to its living representative; the character of this fructification lends no support to the suggested relationship between Thyrsopteris and $O$. Mantelli.

The figures of Thyrsopteris insignis ${ }^{3}$ show a striking resemblance to $O$. Mantelli, but in the larger specimens there appears a certain difference of habit, and, in addition to this, Fontaine refers to some other differences in detail. His figures of the variety angustipennis would at once be taken for $O$. Mantelli, were it not that the rachis is not winged and that other points of divergence are insisted on. The same reference has been made by Velenorsky ${ }^{5}$ to Thyrsopteris in the case of ferns which must now be included under the genus Onychiopsis.

In a recent paper by Nathorst, ${ }^{6}$ referred to in the list of synonyms, we find the statement that Sphenopteris Lantelli will

\footnotetext{
1 Potomac Flora, p. 123.

2 Ibid. p. 128.

3 Ibid. pl. xliii. figs. 1-3.

4 1bid. pl. xlii. fig. 3 ; pl. xliii, fig. 2 .

5 Abh. k. böhm. Ges. Wiss. vol. ii. 1888, p. 10.

6 Loc. cit. p. 55.
} 
become Onychiopsis ILantelli; this change being a necessary consequence of the discovery by Yokoyama of fertile pimns in Onychiopsis elongata (Geyl.), a Japanese plant very closely allied to the Western O. ILuntelli. Previous to Yokoyama's important paper in the Journal of the Imperial University of Japan, in which the generic name Onychiopsis is first proposed, a very similar fern with fertile segments had been figured by Velenorsky, from the Cenomanian beds of Bohemia, under the name Thyrsopteris capsulifera; ${ }^{3}$ these species, as Nathorst remarks, must also pass into the newer genus. These discoveries of such characteristic Onychium-like fructifications enable us to include under Yokoyama's genus a group of plants previously referred to Sphenopteris, Thyrsopteris, Dicksonia, etc., and, at the same time, afford valuable evidence as to the existence of an Onychium type of fern in Upper Mesozoic times in England, North Germany, Bohemia, Japan, and several other districts.

Finally, the same species has recently been recorded by Engelhardt from the Cenomanian of Niederschöna; unfortunately no figures accompany the description.

As Zeiller ${ }^{2}$ has pointed out, this discorery of a Wealden fern in rocks referred to a higher horizon in the Cretaceous system is of considerable interest.

In the diagnosis of the species reference has been made to the characters of the fertile pinnæ, which will be more fully dealt with in the descriptions of such examples as occur in the collections (V. 1069, V. 2151, V. 2159, V. 2159a). Having found the fertile specimens of this well-known species I endeavoured to determine what genus of recent ferns might best be taken as the nearest living representative; the two genera Onychium, Kaulf., and Cryptogramme, R. Br., appeared to come nearest to the fossil forms, but of the two the former showed a more intimate resemblance.

No distinct traces of sporangia hare been detected in the fossil species, and the comparison between Onychium and Onychiopsis Mantelli is, therefore, based on the general habit of the fertile fronds and the form of the sporangiferous pinnules. Whilst still in doubt as to how far the evidence at command warranted a change 
of name, I found that Yokoyama ${ }^{1}$ had figured and described the same kind of fertile pinnæ in a Japanese "Jurassic" fern very closely allied to the European Onychiopsis Mantelli; but in his description of the Japanese species, Onychiopsis elongata (Geyl.), there is no reference made to Brongniart's species. He compares his fertile specimens to the same recent genera already referred to, Onychium, Kaulf., and Cryptogramme, R. Br., and on the strength of the strong likeness to the former he founds his new genus, Onychiopsis. There is such an exceedingly intimate connection between Yokoyama's species and our English specimens, that I hare no hesitation in following the suggestion previously made by Nathorst, and altering the well-known Sphenopteris Mantelli, Brong., to Onychiopteris Mantelli (Brong.), thus substituting for a provisional generic name one which recognizes the botanic affinity of the Wealden species.

V. 2168. Pl. II. Fig. 1.

A very fine specimen, and much larger than any hitherto figured of this species. It shows rery clearly the general habit of the tripinnate frond, but the details are not clearly defined. Length of frond $18 \mathrm{~cm}$., breadth about $12 \mathrm{~cm}$. The resemblance of some parts of this specimen to Heer's figures of Sphenopteris valdensis has already been alluded to; there is also a distinct agreement between the pinnæ and the fragment figured by Tate from South Africa as S. antipodum. Ecclesbourne.

Rufford Coll.

\section{2151a. Pl. III. Fig. 1.}

In this specimen we hare an exceedingly delicate (?) frond which, on a smaller scale, repeats the characters of the species as represented in V. 2168, Pl. II. Fig. 1. The marked difference in size led me to consider the advisability of instituting a variety, O. Mantelli, var. minor, but such a course would merely serve to multiply terms, and would not be supported by any characters of trustworthy value as regards natural affinity. A difference in size, although strongly marked, is not a character to be lightly insisted on as a basis for a species or variety when we are dealing with fragments of fossil plants. Ecclesbourne.

Rufford Coll.

1 Journ. Coll. Sci. Japan, vol. iii. 1890, p. 26, pl. ii. figs. 1-3. 
V. 1069. Pl. III. Fig. 4. Eeclesbourne.

Presented by P. Rufford, Esq., 1885.

V. 2151. Pl. III. Fig. 2.

V. 2159. Pl. III. Fig. 3, and Woodeut, Fig. 4, p. 50.

V. 2159a. Woodcut, Fig. 5, p. 50.

Ecclesbourne. Rufford Coll.

In Pl. III. Fig. 2 (V. 2151) we have portions of pinnæ showing all the characteristics of Onychiopsis Ifuntelli. At $a$ the lower part of a pinna is preserved with the axis prolonged, and bearing alternately disposed narrow orate appendages; these appendages must be regarded as fertile segments of the pinna. There is a gralual transition seen from the sterile to the fertile part in the right-hand fragment shown in Fig. $2 a$. In the same Figure, at $b$, the terminal portion of a fertile pinna is more perfectly preserved, and here the distal end of the axis has the characteristic serrate form of the tip of an ordinary sterile frond.

In PI. III. Fig. 4 (V. 1069) three fertile axes are shomn; these, if taken alone, would doubtless be referred to a position far removed from Onychiopsis IIantelli, but if we compare them with the terminal portions of the pinnæ of Fig. 2 (V. 2151), there can be no doubt as to their real nature. At the tip of the right-hand axis the serrate character is readily seen, as previously noticed in Pl. III. Fig. 2b, but this is rather too small to be distinct in the figure. The specimen (V. 1069) shown in Fig. 4 affords strong proof of the intimate relationship between 0 . Mlantelli and 0 . elongata (Geyl.), as figured by Geyler. ${ }^{1}$

The details of the fertile segments are best seen in Pl. III. Fig. 3 (V. 2159); three of the segments are enlarged $3 \frac{1}{2}$ times in the Woodeut, Fig. 4 (p. 50).

In the Woodeut, Fig. 5, four segments of another specimen are also enlarged $3 \frac{1}{2}$ times; these are somewhat shorter and show a much more distinct median line. Compare with these figures Yokojama's figure of 0 . elongata $;^{2}$ there is a close agreement, as regards the fertile segments. Cf. also Velenorsky's figure of Onychiopsis (Thyrsopteris of Velenorský) capsulifera, Vel. ${ }^{3}$

1 Palæontographica, vol. xxiv. pl. xxri. fig. 5.

2 Yokoyama, loc. cit. pl. ii. fig. $4 b$.

3 Velenorský, loc. cit. pl, i. fig. 10. 
An examination with a low magnifying power enables us to describe the fertile segments as swollen, narrow, orate bodies, often prolonged at the apex into a delicate amn-like termination; with rugose surfaces, a thin flattened margin, and occasionally a longitudinal median depression. The roughness of the surface on further enlargement, e.g. Fig. 4, resolves itself in some of the better specimens into small circular areas, which probably mark the position of sporangia.
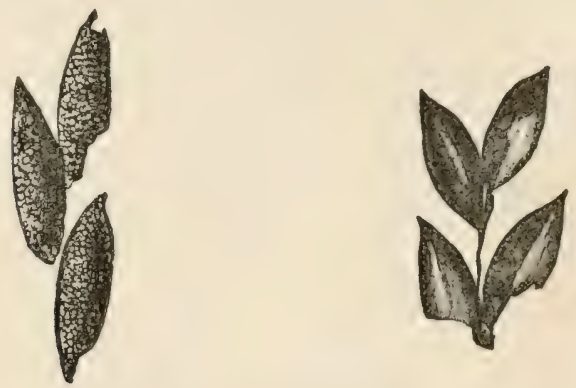

Fertile segments of Onychiopsis Mantelli (Brong.).

FIG. 4 (V. 2159).

Enlarged $3 \frac{1}{2}$ times.

Fra. 5 (V. 2159a).

Enlarged $3 \frac{1}{2}$ times.

Among recent ferns there can be little doubt that Onychium comes nearest to $O$. MLantelli in the form of the fertile segments. The sporangia are clustered together in oral sori corered by an indusium, and often prolonged apically into a delicate appendage. The circular areas referred to in the fossil no doubt indicate sporangia, and the median groove seen in some cases, if not an accident of preservation, may correspond to a similarly situated depression in the sori of Onychium. The flat and thin margin in all probability corresponds to the flattened indusium border in the recent genus. Fée's figures of Onychium ${ }^{1}$ show very clearly the character of the fertile pinnules. Some specimens of Onychium auratum, Kaulf, in the Botanical Department Herbarium of the British Yuseum show fertile segments strikingly similar in form to those of the Wealden fern; in the recent species the arrangement of these sporangiferous segments is looser and less compact and regular than those shown in Pl. III. Figs. 1 and 2. The recent

1 Fée, Genera Filicum, pl. vii.c. 
specimens also show a similar passage from the fertile part of a pinna to a terminal serrate portion, as represented in the fossil specimens, Pl. III. Figs. 2-4. Onychium Japonicum, Kunze, also agrees very well with the fossil species.

These resemblances appear to me amply sufficient to justify the adoption of the name Onychiopsis in place of Sphenopteris, in spite of the fact that we are unable to decide how far the sporangia support this reference to the Polypodiacece.

Fertile fronds of Cryptogramme crispa, R. Br., also approach fairly closely in appearance to those of 0 . Mantelli, but the likeness is much less pronounced than in the case of Onychium.

Since writing the above I have found that the Marquis of Saporta has recorded the occurrence of fertile specimens of Sphenopteris Mantelli at Quinta-do-Leiriâo, ${ }^{1}$ and other localities in Portugal; he considers that the fructification agrees most closely with that of Darallia, especially D. gibberosa, Sw. ${ }^{2} \mathrm{My}$ thanks are due to the Marquis of Saporta for some further details as to the Mesozoic flora of Portugal which he has very kindly communicated to me. In a letter recently received (December 30, 1893), he states his opinion that the reference of Sphenopteris Mantelli to the recent genus Davallia seems to be more natural than that of Yokoyama, who refers the closely-allied species, S. elongata, to Onychium; at the same time Saporta does not consider the question as definitely settled. In the forthcoming monograph on the Mesozoic flora of Portugal we shall have plates and detailed descriptions, which will enable us to consider more fully the rival claims of Davallia and Onychium as to which is the most nearly allied genus to the widely distributed Wealden species. Meanwhile, I do not wish to alter my opinion that the eridence afforded by the English specimens is distinctly in favour of the substitution of Onychiopsis for Sphenopteris, as expressing the most probable relation of the fossil fern to the genus Onychium.

V. 2189. Woodeut, Fig. 6.

This specimen, with several others, e.g. V. 2188, V. 2314a, etc., probably represents part of a rizizome of 0 . Mtuntelli. The surface

1 Rev. gen. bot. vol. v. 1893 , p. 272.

${ }^{2}$ I am unable to detect in fertile fronds of Darallia gibberosa any distinet resemblance to the fossil form. 
of the repeatedly branched stem is corered with small scaly structures, reminding one of the rhizome of the Hare's-foot fern. Some of the specimens are larger than that shown in the Figure, but are not so clearly preserved; in all cases there occur fragments of 0 . Mantelli fronds in close association with the branched scaly structures. Ecclesbourne.

Rufford Coll.

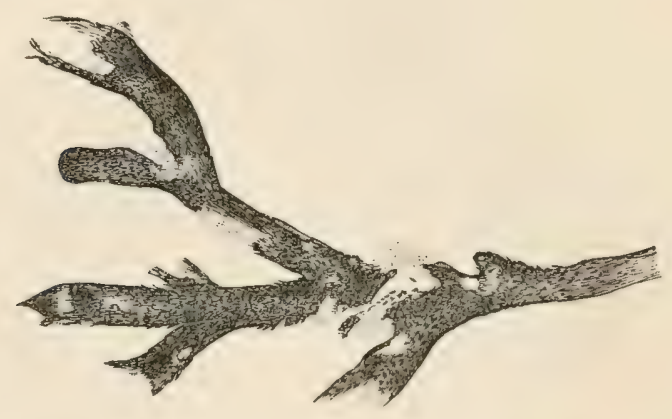

Fig. 6 (T. 2189). Part of a rhizome of Onychiopsis IIantelli. (Natural size.)

V. 709. Rachis shown very clearly. Tilgate Forest.

Purchased.

V. 723. This fragment looks very like the terminal portion of a fertile frond or pinna. Cf. Yokoyama, loc. cit. pl. ii. fig. 4 (O. elongata). Ecclesbourne.

Rufford Coll.

V. $1069 a$. Distinct rachis. This specimen shows some pinnæ with long close-set pinnules rery similar to those of 0 . elongata. Cf. V. 23\%1, Pl. II. Fig. 3. Cf. Thyrsopteris microphylla, Fontaine, loc. cit. pl. xl..; also T. sp., pl. xliii. Near Hastings.

Rufford Coll.

V. 1069b. Rhizome with associated fragments of pinnx. Ecclesbourne.

Rufford Coll.

V. 2151 . Very similar to V. 2151, Pl. III. Fig. 2.

V. 21516. Portion of a well-preserved frond. Ecclesbourne. Rufford Coll. 
V. 2188. A much branched and spreading rhizome, with its surfice covered with small depressions representing the points of attachment of scales; in some places there is a carbonaceous covering preserved. As usual with specimens of this kind there are associated fragments of 0 . Mantelli pinnæ. This form of rhizome resembles that which is characteristic of some recent Davallias, and is more spreading than the usual form met with in species of Onychium. Such differences, however, in the nature of the stems need not be looked upon as an argument of very great weight in questions of generic affinity, when Mesozoic and Recent ferns are compared. Ecclesbourne.

Purchased 1839.

V. 2231. Rhizome fragments with scaly surface markings, and on the same specimen portions of fronds. $C f$. Woodcut, Fig. 6, p. 52, V. 2189. Ecclesbourne.

Rufford Coll.

V. 2235. Part of a spreading rhizome with less clearly preserved leaf fragments. Ecclesbourne.

Rufford Coll.

V. 2241a. Several well-preserved sterile pinnæe and portions of sterile fronds on a large slab. Ecclesbourne.

Rufford Coll.

V. 2314. Fragments of circinately rolled fern fronds, one much more perfect than the others. There are also several pieces of rhizome-like structures, some showing the characteristic scaly appendages. On the same slab of sandstone occur fragments of what may be $O$. MLantelli, but they are very indistinct and doubtful. I have included this specimen under the head of 0 . Mantelli, although there is no absolute proof that the rarious fragments really belong to that fern. $C f$. Schenk, Palæontographica, vol. xix. pl. xxx. figs. 4 and 5, also vol, xxiii. pl. xxri. fig. 2.

V. 2314 $a$. Probably a rhizome with the basal portions of petioles attached; shows the rough scaly surface. Ecclesbourne.

Rufford Coll.

V. 2348. Rachis clearly preserved, $12.5 \mathrm{~cm}$. long. Somewhat less compact in habit than most examples of the species. Ecclesbourne.

Rufford Coll.

V. 2369. Rhizome fragments with leaf-stalks attached; also pieces of pinnæ. Ecclesbourne.

Rufford Coll. 
V. 2616. Under this number there are two specimens of a coarser form of 0 . Mrantelli. Sussex.

Beckles Coll.

7354. Two small specimens (one without a registered number, but probably the reverse of 7354 ), which closely resemble some fragments figured by Mantell ${ }^{1}$ and Brongniart. ${ }^{2}$ Tilgate Forest.

Mantell Coll.

8390. This agrees closely with Mantell, loc. cit. pl. xx. fig. 2, and Brongniart, loc. cit. pl. xlv. fig. $7 a$. It is possible that the figured specimen was the reverse piece of the Museum example. Tilgate Forest.

Mantell Coll.

32593. Shows a prominent rachis projecting from the surface of the sandstone. Tilgate Forest.

Mantell Coll.

38367. Part of a pinna. This specimen bears a certain resemblance to that figured by Stokes and Webb, ${ }^{3} \mathrm{pl}$. xlvi. fig. 7 , and reproduced in Mantell's "Geol. S.E. England," and in Brongniart's "Hist. vég. foss." There are, however, distinct differences between the specimen and the figures referred to, which compel me to merely suggest the possibility of the Museum specimen being the reverse piece of Stokes and Webb's original. Tilgate Forest.

Mantell Coll.

38372. In all probability this is the type specimen of Mantell's Sphenopteris Sillimani, figured in the "Geol. S.E. England," p. 239. Hastings Sands, Sussex.

Mlantell Coll.

The following specimens do not call for any special mention. V. 14, Hastings, purchased; V. 724 and V. 726, Hastings, Dawson Coll.; V. 728 and V. 2232, Ecclesbourne, Rufford Coll.; V. 2615, V. 2856, V. 2862, V. 2868 and V. 2876, near Hastings, Beckles Coll. ; 8084 and 8361, Tilgate Forest, IKantell Coll. ; 52942 (sereral specimens with this registered number), Ecclesbourne, presented by J. E. H. Peyton, Esq.

1 Illust. Geol. Sussex, pl. i. figs. $3 a, 3 b$.

2 Hist. vég. foss. pl. xlv. fig. 4.

3 Trans. Geol. Soc. ser. ii. vol. i. 


\section{2.--Onychiopsis elongata (Geyler).}

1871. Sphenopteris Göpperti, Schenk (in part), Palicontographica, vol, xix. pl. $\mathrm{xrx}$. figs. 2 and $2 a$ (not the other figures).

1877. Theyrsopteris elongata, Geyler, Palkontographica, vol. xxiv. p. 221.

1883. Thyrsopteris elongata, Schenk, Richthofen's China, vol. iv. p. 263, pl. liv. fig. 1.

1886. Dicksonia elongata, Yokoyama, Bull. Geol. Soc. Japan, rol. i. No. I, p. 5 .

1889. Thyrsopteris rarinervis, Fontaine, Potomac Flora, p. 124, pl. xxri. figs. 6 and 7 ; pl. xliii. figs. 4-6; pl. xliv. figs. 1, 2 and 5 ; pl. xlix: fig. 2 ; pl. clxix. figs. 6 and 7.

1890. Onychiopsis elongata, Yokoyama, Journ. Coll. Sei. Japan, vol. ii. p. 27 , pl. ii. figs. 1-3; pl. iii. fig. $6 d$; pl. xii. figs. 9 and 10.

1890. Onychiopsis elongata, Nathorst, Deukschr. k. Ak. Wiss. math.-nat. Cl. vol. lvii. p. 55.

Type. Sterile and fertile portions of frond.

The species, instituted by Geyler from specimens found in the Province of Kaga, Japan, is thus defined ${ }^{1}$ :-

"Th. fronde bi-tripinnata, pinnis pinnulisque elongatis, pinnulis inferioribus imprimis longissimis; pinnulis sterilibus crenatis seu pinnatifidis in apicem sensim protractis, lobis obtusinseulis, pinnulis fertilibus eodem modo valde elongatis, involucris breviter stipitatis, oralibus seu ? rotundatis."

The few fragments in the Museum collections referred to this species add nothing to the definitions given by Geyler and Yokoyama; the latter had the more perfect material at his disposal, and his diagnosis may therefore be reproduced rerbatim.

"Frond slender," bi-tripinnated; sterile pinnæ alternate or rarely opposite, elongated, their length rapidly increasing towards the lower part of the frond; pinnules alternate, acutely directed forward, lanceolate or linearly-lanceolate, entire or lobed, or even pinnately parted; lobes or partitions acute at apex and acutely directed formard just like the pinnules themselves. Venation. obsolete, secondary veins simple, each going into a lobe. Fertile pinnules elongated, with a linear terminal sorus on both sides of the midrib."

Geyler compares his species with some preriously described and figured by Heer under the generic name Thyrsopteris, from East

1 Palæontographica, vol, xxiv. p. 224.

2 Journ. Coll. Sci. Japan, vol. iii. p. 27. 
Siberia and Amurland, and considers the resemblance close enough to justify the inclusion of the Japanese species in the same genus. The resemblance between the fertile axis of $O$. elonguta, figured by Geyler, to those of 0 . Ifantelli (V. 1069, Pl. III. Fig. 4) has already been referred to.

In Richthofen's "China" Schenk figures some portions of a frond from Japan, without any more exact locality, which he places with Geyler's species. Most probably, as Schenk points out, this specimen belongs to the common Japanese type, O. elangata (Geyl.).

Schenk's figure of Sphenopteris Göpperti, referred to in the synonomy, seems to me indistinguishable from $O$. elongata. $C f$. Schenk, Palæontographica, vol. xix. pl. xxx. fig. 2, and Pl. II. Fig. 2 of this Catalogue.

Yokoyama, in the first of the two papers referred to above, includes $O$. elongata in his list of fossils under the name Dicksonia elongata; in his second and more important work, the genus Onychiopsis is substituted for the original name of Dicksonia. $\mathrm{He}$ speaks of the species as the "chief and characteristic fossil of the Japanese Flora, being found in all of the fossil localities." 1 From Fontaine's long list of the speeies of Thyrsopteris I hare included one as a synonym of $O$. elongata; but it is not at all unlikely that several of the Potomac "species" ought to be placed, if not in the same species, at least rery near to the Japanese form. In the general remarks at the end of the Potomac Monograph we have the following statement with regard to the genus Thyrsopteris: ${ }^{2}$ "It is true that, as no fructification has been found on these ferns, they may be incorrectly placed in the genus Thyrsopteris." "The species," says Fontaine, "most of then well characterized, number forty." A number of them are described as possessing "the same type of foliage as the Wealden ferns, S. Mantelli, Brong.; S. Göpperti, Dunker; S. Cordai, Schenk; S. plurinervia, Heer; and S. Gomesiana, Heer." Lastly, we are told, "most of them are new and unique. One or two have some resemblance to Oolitic species, while a greater number may be grouped as belonging to the two Wealden types, S. MFantelli and $S$. Güpperti."

Here we have forty new species founded on sterile fronds, or

1 Loc. cit. p. $2 \mathrm{~S}$.

2 p. 120. 
portions, sometimes extremely minute portions, of fronds, and all placed in the recent genus Thyrsopteris. One would naturally expect that this remarkable assemblage of species, called by the name of a unique living genus, should rest on trustworthy eridence. The author of these forty species himself admits that no fructification has been found; surely this admission will be sufficient in itself to make botanists pause before they allow themselves to be lost in contemplation of the wealth of specific form displayed by these Potomac plants, or to assume as an established fact that Kunze's solitary species was represented in the Potomac vegetation by such a host of ancestors. We may justly ask-Are there differences enough, and sufficiently well marked, between these numerous varieties to warrant the result arrived at; and, secondly, is the evidence at hand strong enough to justify the use of the name Thyrsopteris, or even a modification of it which would be suggestive of something not quite so certain and well founded?

To the first question I am strongly of opinion that the answer is a decided negative. It must be admitted that my eridence is entirely based on an examination of Fontaine's figures and descriptions, and has not the weight of testimony derived from an actual inspection of the specimens themselres. To the second question, the admission that no trace of a fertile pinna or pinnule has been recognized is, I am disposed to think, a sufficient reply. It would be a presumption and bejond my province, to attempt to describe how many species are represented by the "Thyrsopteris" specimens found in the Potomac beds; but it is at least possible to indicate a few of those cases in which the determinations of Fontaine are not such as I feel able to accept.

The species T. Firginica ${ }^{1}$ is founded on specimens of the "pinnre of ultimate order," and the fragments figured might easily be included in some of the thirty-nine remaining forms without the unnecessary institution of an additional species. Another instance of the same kind is afforded by $T$. alata, which depends for its existence on part of a pinna apparently indistinguishable from T. Meekiana.

In describing $T$. rarinervis " Fontaine refers to it as "one of the

1 Loc. cit. p. 120, pl. xxiv. fig. 1.

2 Loc. cit. p. 123. 
Sphenopteris Mantelli type," and adds: "It resembles more than any other described fossil Thyrsopteris elongata, Geyler." If we look at Fontaine's pl. xxvi. figs. 6 and 7 , and compare with Geyler's pl. xxxi. fig. 4, it is well-nigh impossible to agree that these are different species, to say nothing of distinct genera; or, again, it is difficult to separate, on good grounds, fig. 2, pl. xliv. of Fontaine from Onychiopsis elongata as figured by Yokoyama, pl. ii. fig 2. It is true that Fontaine's specimens show in some cases a stouter rachis than occurs in the Japanese examples.

There seems to be but slender evidence in support of T. Meekiana, var. angustiloba. Cf. O. elongata; e.g. Fontaine, pl. xliii. fig. 8, and Yokoyama, pl. ii. fig. 2.

The species of Onychiopsis described by Velenorsky, ${ }^{1}$ referred to below, should be compared with $T$. crenata, pl. xxxix. fig. 1, Fontaine, and Velenorský, pl. i. fig. 9.

In T. densifolia, Font., we have a fern which seems to be very similar to Yokoyama's fig. 2, pl. ii. of $O$. elongata; the difference consists in the somewhat broader pinnules of the former. The figures of $T$. densifolia suggest a form of plant identical with that represented by T. Meekiana, Font., e.g. pl. xxxviii. fig. 3 .

Another of these "Thyrsopteris" species, T. microphylla, is referred by Fontaine to the "Sphenopteris Mantelli type," and the figures of this species appear to me illustrations of the plant included under the name $T$. angustifolia; both come near to $O$. elongata. Compare also T. pimnatifida, Font., pl. li. fig. 2, etc., with 0 . elongata, and with the latter species $T$. incoquipinnata, Font.

T. elliptica, Font, is described as "not very close to any previousiy described fossil ;" 2 there appears, indeed, to be a rather close resemblance between the figures of this species, pl. xlvi. fig. 1, and T. densifolia, Font., pl. xl. fig. 4. In addition to the two species $T$. Firginica and T. alata, to which allusion has been made as examples of specific determinations which are without such claim as entitles them to serious recognition as well-defined types, a third may be mentioned, T. heterophylla, Fout., which does not appeal more strongly for acceptance, if we may judge by the figured fragments, pl. lviii. figs. 3 and $3 a$.

1 Loc. cit. p. 10, pl. i. figs. 6-12.

2 Fontaine, loc. cit. p. 133. 
Although not included under the present species, $O$. elongata, there is a plant which must be bricfly alluded to as an example of the same genus, and probably very closely allied to Geyler's species. In 1888 Velenorský contributed an important communication, apparently overlooked by some recent writers, on "Die Farne der bühmischen Kreideformation"; he includes in his list of Cenomanian ferns from the Perucer beds a new species, Thyrsopteris capsulifera, ${ }^{1}$ and compares it to T. Maakiana, Heer, and especially to $O$. elongata (Geyler). Sereral figures are giren both of sterile and fertile pinne, and the figure of the fertile axis, pl. i. fig. 10, represents what is obviously the same type of fertile pinna as Geyler's pl. xxxi. fig. 5 and Hl. III. Figs. 2-4 of this Catalogue. Possibly the differences which are shown in the figures by Velenorský, Gejler, and Yokoyama, between T. capsulifera and $T$. elongata, are hardly of sufficient importance to render a second specific name necessary; the chief divergence being the greater breadth of the ultimate segments in most of the Bohemian specimens.

Nathorst, ${ }^{2}$ in calling attention to this paper by Velenorsky', notes the fact that the species $T$. capsulifera possesses fructification exactly like that of $O$. elongata, and must, therefore, be included in the same genus.

In looking through the English Wealden material it has often been difficult to decide the limits to assign to the two species $O$. Irantelli and O. elongata; the coarser forms of the former come very near to the latter species.

So far, howerer, I have included only one specimen in this species. It is not impossible that we may erentually have to include eren those forms with larger and broader pinnules in the species O. ILantelli; for the present, at least, there seem to be good reasons for referring such specimens as the one figured, Pl. II. Fig 2, to Geyler's species.

\section{2371. Pl. II. Fig. 2.}

In this Figure are represented the best of sereral fragments which occur on the same piece of rock. On the same specimen are some badly preserved fragments of Cladophlebis Dunkeri (Schimp.).

1 Abk. k. böhm. Ges. Wiss. vol. ii. 1888, p. 10.

${ }^{2}$ Denkschr. k. Ak. Wiss. math. -nat. Cl, vol. Ivii. p. 55. 
Cf. Thyrsopteris Meekiana, var. angustiloba, Font., pl. 1ri. etc.; also Sphenopteris IIantelli, Schenk, Palæontographica, vol. xix. pl. xxт. fig. 6; Sphenopteris Göpperti, Schenk, loc. cit. pl. xxx. fig. 2; and Asplenium Dicksonianum, Heer, from the Kome beds of Greenland, Fl. foss. Arct. iii. pl. i. Ecclesbourne.

Rufford Coll.

\section{Genus ACROSTICHOPTERIS, Fontaine.}

[Potomae Flora, U.S. Geol. Surv. Monograph, xv. 1889, p. 106.]

Tontaine has instituted this genus for certain fossil ferns "peculiar to the Potomac formation"; he considers that it stands nearest in most features to Acrostichum among recent genera.

The genus is thus described ${ }^{1}:-$

"Fronds, probably creeping, with rery long, often flexuous, rachises, which seem to have been more or less succulent; pinnæ going off obliquely, long and apparently slender; ultimate pinnæ or pinnules sub-opposite to alternate, comparatirely short, aud cut down nearly to the rachis into more or less cuneate-flabellate pinnules or primary segments. These are dirided generally into cuneate-flabellate segments, which in turn are separated into oblong segments ending in oblong, or orate-obtuse, or acute teeth; pinnules decurrent and forming a wing; nerres slender but distinct, flabellately diverging, forking dichotomously, and ending in the teeth; fructification occurring on the basal segments of the pinnules, in the upper portions of the frond on the upper one alone, in the lower portions on the upper and lower ones; the fructified segments, which on the lower side are corered by the naked sori, and scen from the upper side, especially when compressed on the clay, look like pods."

In the figures of the Potomac species of this genus there are several fertile specimens shown, but no detailed sporangial structure. Perhaps the best figure is that of a fertile pinnule of Acrostichopteris longipennis, Font., pl. clxxi. fig. 7a. Fontaine concludes that "the genus in the naked sori is like Polypodum, but in 
most features stands nearest to Acrostichum, much resembling the section Rhipidopteris. In this latter, however, the fructification is borne on separate pinnules. If we place the fructified pinnules of Rhipidopteris as basal segments on the sterile ones, we have a form strikingly like Acrostichopteris. The genus has also some resemblance to Marsilea."

It is doubtful if the generic name Acrostichopteris be the most suitable for such specimens as the English rocks hare afforded. In Fontaine's specimens there is some evidence as to fructification characters, but in the few fragments from Ecclesbourne there are no traces of fertile leaves. The similarity, howerer, between the American and English specimens appears to be exceedingly close, and the habit represented by the various species is not one which occurs rery commonly among recent genera.

In the recent species Acrostichum peltatum, $\mathrm{Sw},{ }^{2}$ the sterile leares have the same deeply divided pinnules with narrow segments as those of $A$. Ruffordi, but in the latter form there are several pairs of pinnules attached to one axis; the difference in the arrangement of the fertile pinnules has already been alluded to by Prof. Fontaine.

It is difficult to determine whether such specimens as those described below should be spoken of as pinnæ of a frond with a creeping rachis, or as the pinnate leaves of a creeping rhizome, as in Acrostichum peltatum. I have placed the genus in the Polypodiacece on the strength of Fontaine's conclusions, drawn from much more complete material than the British Museum affords. The eridence as to family characters is best seen in the figures of American specimens; it is by no means all that could be desired.

\section{1.-Acrostichopteris Ruffordi, sp. nov.}

Type. Pinnæ and portions of rachis. In the British Mruseum.

Main rachis probably creeping, bipinnate, pinnæ linear; pinnules alternate, rhomboidal or cuneate, deeply divided into narrow cuneate segments with acute or obtuse teeth. Venation of the Ctenopteridis type. No fructification preserved.

1 Potomac Flora, p. 106.

2 Fée, Genera Filicum, pl. ii. 
This species comes very near to Acrostichopteris densifolia, ${ }^{1}$ Font., but differs in the shape of the pinnules; in $A$. Ruffordi they are less orbicular in form, but on the other hand shorter than in another Potomac species, A. longipennis, ${ }^{2}$ Font.

V. 2327. Pl. VI. Fig. 3.

A single sterile pinna, or possibly a pinnate frond. The repeatedly forked reins well shown, with their single branches in the narrowly linear ultimate segments. Ecclesbourne. Rufford Coll.

V. 2327a Fragments of pinnæ, also what is probably part of the main rachis of the frond showing the point of attachment of one pinna. Close to this portion of the rachis there is a flexuous structure which at first sight appears to be a continuation of the former piece; the two are, however, at slightly different levels in the ironstone matrix, but in all probability both may be regarded as fragments of the rachis; on the second piece there are here and there the beginnings of several lateral branches which may possibly be roots. Ecclesbourne.

Rufford Coll.

\section{Family CYATHEACE无.}

The oblique annulus and the transverse dehiscence of the sporangia are the chief distinguishing features of this family.

The genus Matonidium, Schenk, may probably be regarded as a Wealden representative of the recent genus Matonia, $\mathrm{R}$. Br.; the latter, according to Baker, ${ }^{3}$ should be placed in a tribe by itself, and not united with the Cyatheacece.

\section{Genus MATONIDIUIM, Schenk.}

[Palæontographica, vol. xix. 1871, p. 219.]

This genus, founded on specimens of sterile and fertile fronds from the Wealden of North Germany, is thus defined:-

"Folia sterilia et fertilia conformia flabellato-pinnata, segmenta

1 Potomac Flora, p. 107, pl. xciv. fig. 4 ; pl. clxx. fig. 11, etc.

2 Ibid. p. 107, pl. clxx. fig. 10 ; pl. clxxi. figs. 1, 5 and 7.

3 Annals Bot. vol. v. 1890-91, p. 192. 
pinnatifida. Nerri primarii excurrentes, secundarii angulo subrecto egredientes dichotomi, ramuli simplices. Sori biseriales oblongi indusiati. Sporangia receptaculo in ramulo affixa. Annulus obliquus."

When this fossil genus was first instituted by Schenk there was only one species recorded of the recent Matonia, and the characteristic and peculiar habit of that species, $\boldsymbol{I}$. pectinata, Br., suggested the term Iatonidium for fronds of similar form. It is important, in speaking of this similarity of form and of the Mlatonia-like habit, to remember the recent addition of a second species, 1 . sarmentosa, Baker, ${ }^{1}$ which has an entirely different habit to that which has always been regarded as typical of the genus. Baker's figure of this new species shows in a striking manner the danger of trusting to sterile portions of fronds in the determination of generic affinity.

\section{1.-Matonidium Göpperti (Ett.).}

1843. Cycadites Althausii, Dunker, Progr. p. 7.

1846. Pecopteris Althausii, Dunker, Wealdenbildung, p. 5, pl. ii. fig. 2. Fecopteris polydactyla, Dunker, loc. cit. p. 5, pl. vii. fig. 4.

Pecopteris Conybeari, Dunker, loc. cit. p. 7, pl. ix. figs. 8 and $8 a$. Alethopteris elegans, Dunker, loc. cit. p. 8, pl. vii. fig. 7 .

1849. Pecopteris polydactyla, Brongniart, Tableau, p. 107.

Pecopteris Conybeari, Brongniart, loc. cit. p. 107.

Pecopteris Althausii, Brongniart, loc. cit. p. 107.

Pecopteris elegans, Brongniart, loc. cit. p. 7.

1850. Pecopteris polydactyla, Unger, Gen. spec. plant. foss. p. 177.

Pecopteris Conybeari, Unger, loe. cit. p. 177.

Pecopteris Althausii, Unger, loc. cit. p. 176.

Alethopteris elegans, Unger, loc. cit. p. 147.

1852. Alethopteris Göpperti, Ettingshausen, Abh. k.-k. geol. Reichs. rol. i. Abth. iii. No. 2, p. 16, pl. .

1854. Alethopteris elegans, Morris, Brit. foss. p. 2.

1864. Pecopteris polydactyla, Leckenby, Quart. Journ. Geol. Soc. vol. xx. p. 80 , pl. xi. figs. $1 a$ and $1 b$.

1869. Laccopteris Göpperti, Schimper, Trait. pal. rég. rol. i. p. 582, Atlas, pl. $\mathrm{xxx}$. figs. $5-8$.

1870. Pecopteris Althansii, Trautschold, Nouv. Mém. Soc. Nat. Moseou, vol. xiii. p. 28, pl. xix. figs. $3 d$ and $e$.

? Pecopteris explanata, Trautschold, loc. cit. p. 32 , pl. xix. fig. 7.

I Annals Bot. vol. v. 1890-91, p. 191, pl. xiv. (First described in Journ. Linn. Soc. Fol. xxiv. 1888, p. 256.) 
1871. Matonidium Göpperti, Schenk, Palæontographica, rol. xix. p. 219, pl. xxvii. figs. 5 and $5 a$; pl. xxviii. figs. 1 and 2 ; pl. xxx. fig. 3 .

1874. Matonidium Göpperti, Schimper, loc. cit. vol. iii. p. 507.

1875. Matonidium Göpperti, Schenk, Palæontographica, vol. xxiii. p. 160, pl. xxvii. fig. 9 .

1875. Pecopteris polydactyla, Phillips, Geol. Yorks. p. 207.

? Pecopteris caspitosa, Phillips, loc. cit. p. 207, fig. 20 ; pl. viii. fig. 10.

1878. Alethopteris elegans, Dupont, Bull. Ac. Roy. Belg. vol. xlvi. sér. ii. p. 396.

Pecopteris Conybeari, Dupont, loc, cit. p. 396.

1881. Matonidium Göpperti, Heer, Secc. Trab. Geol. Portugal, p. 16, pl. $x \mathbf{x}$. figs, 1-6.

1883. Matonidium Göpperti, Renault, Cours bot. foss. vol. iii. p. 76.

1888. Matonidium Göpperti, Schulze, Flor. subhercyn. Kreid. p. 11.

Type. Large specimens of sterile and fertile segments. In the Berlin Collection.

The material in the British Museum is very much less perfect and more scanty than that at the disposal of Schenk; we may, therefore, quote his definition verbatim : ${ }^{1}$

"Folia petiolata flabellato-pinnata, segmenta brevite petiolata pinnatifida, in foliis junioribus 5-6, in adultioribus usque quatuordecim, ambitu linearia basi et apice attenuata acuminata, adulta 25 centim. longa, laciniæ patentissimæ alternæ vel suboppositæ integræ, inferiora abbreviatæ rotundatæ, medium versus sensim - longiores, mediæ oblongo-lanceolatæ, summæ breviores oratæ, nerri primarii excurrentes, secundarii angulo subrecto egredientes dichotomi, ramuli simplices, sori biseriales oblongi indusiati, sporangia in ramulo affixa, annulus obliquus."

Dunker's figures of this species represent sterile portions of leaf segments; the differences in size led him to separate them as distinct species.

I have decided to follow Leckenby's example ${ }^{2}$ with regard to the reference of the specimens from the Yorkshire Oolite to the present species. A comparison of his figure, pl. ix. fig. 1a, and Schenk's pl. xxrii. fig. 9, Palæontographica xxiii. leaves little doubt as to the specific identity of the two plants. Another Jurassic species, Pecopteris crespitosa, Phillips, appears to me inseparable from Matonidium Göpperti; compare especially wood-

1 Palrontographica, rol. xix. p. 220.

2 Quart. Journ. Geol. Soc. vol. xx. 1864, p. 80. 
cut 20, p. 207 of Phillips' "Geology of Yorkshire" and Schenk, pl. xxviii. Palæontographica, xix.

Trautschold figures from the Klin Sandstone sereral pieces of fronds which undoubtedly come very near the Wealden species.

His figures of Pecopteris Althausii, Dunk, agree with Schenk's of the North German plant, except in a slight difference in size.

Possibly Pecopteris explanata, Traut., should be kept as a distinct species, but this should be referred to Matonidium; as regards habit this plant is very close to Velenorsky's fig. 3 , pl. ii. of Microdictyon Dunkeri (Schenk). ${ }^{1}$ Another Russian species, Pecopteris pachycarpa, Traut., ${ }^{2}$ should also be removed to Schenk's genus, but probably its straighter and less falcate pinnules justify a distinct specific name.

Schenk's later figures of the species throw further light on the character of this fern, and show, amongst other things, that the shape of the pinnules raries considerably in different specimens. The same variation in the size and form of the ultimate segments is shown in Heer's figures of this species from Portugal; possibly some of his specimens should be referred to another species, but it is very difficult to decide what limits to attach to the rariation in size in a single species.

In discussing the position of this species, Schenk notes the close correspondence of the sori and the individual sporangia with the Cyatheacee type, and this similarity as regards the fertile segments is corfirmed by the apparently identical habit of the frond of Matonia pectinata, Br. The sori of the recent species are more circular in form than in Matonidium Göpperti, where they appear to be elliptical; compare e.g. Hooker and Baker, ${ }^{3}$ pl. i. fig. 8, and Schenk, Palæontographica, xix. pl. xxriii. pl. xxviii. figs. 2 and $2 a$.

\section{2218. Woodeut, Fig. 7.}

Portions of several pinnæ having to some extent the characters of Cladophlebis Browniana (Dunk.), but the form of the fructification and the position of the detached pieces on the matrix show

1 Abh. k. böhm. Ges. Wiss. vii. folge, vol. ii. 1888.

2 Trautschold, loc. cit. p. 30 , pl. xix. figs. $6 a$ and $b$.

3 Spnopsis Filicum, 1868. 
their identity with Iratonidium. The position of the pinnæ shows a gradual convergence towards a point of attachment.

The elliptical or oval sori are distinctly shown on the lower surface of the pinnules. Ecclesbourne.

Rufford Coll.

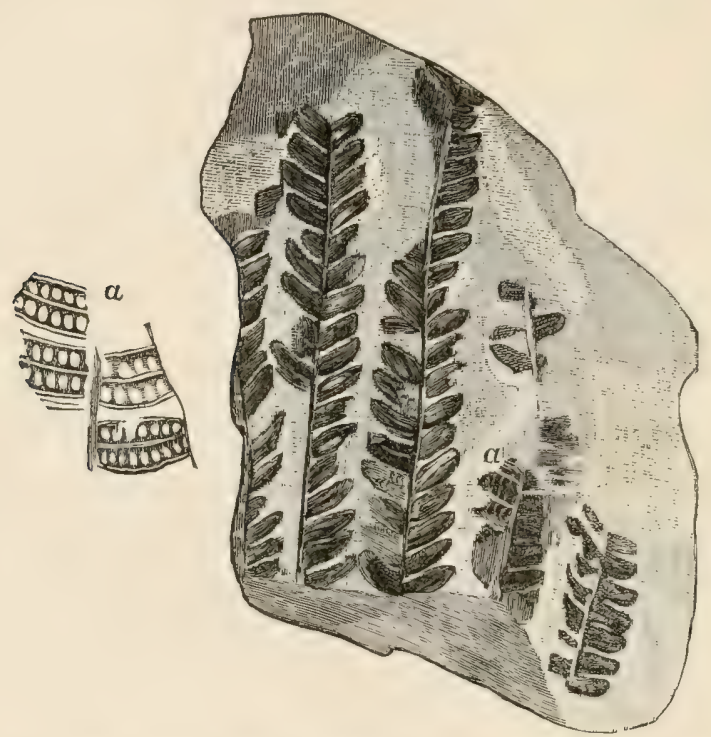

Fig. 7.-Matonidium Göpperti (Ett.), showing portion of a fertile pinna $(a)$ (V. 2218).

V. 721. Rachis very prominent; some of the pinnules with sori. Ecclesbourne.

Dawson Coll.

V. 2208. Very similar to V. 2218. Pieces of six pinnæ. Note the gradual convergence towards the original point of attachment to the stout rachis. Ecclesbourne.

Rufford Coll.

V. 2211. Shows the convergence to a common point of attachment of imperfectly preserved pinnæ. Ecclesbourne. Rufford Coll.

V. 2216. Small fragments of ? fertile pinnæ. Ecclesbourne. Rufford Coll. 
V. 2222. Woodeut, Fig. 8. Portions of several pinnæ conrerging to a large rachis. Far inferior in preservation to Schenk's figured specimens. Ecclesbourne.

Rufford Coll.

V. 2223. On this specimen is a fragment of a fertile pinna showing the position of the sori. Ecclesbourne. Rufford Coll.

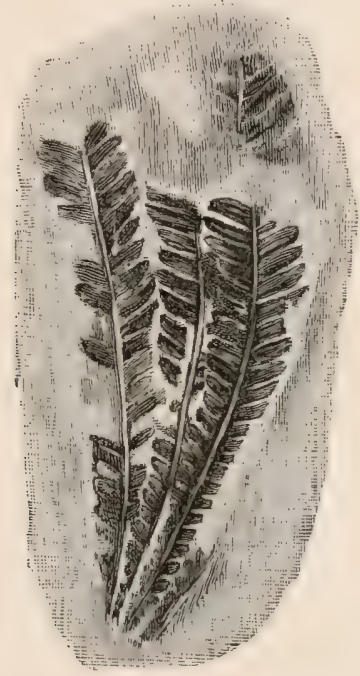

Fig. 8.-MIatonidium Göpperti (Ett.) (V. 2222).

V. 2737. The pinnules are larger than in the other specimens, more like those of Ificrodictyon in size, but their shape is that of Matonidium.

Similar examples of size rariation have been referred to in the figures of Schenk, Heer, and Trautschold. Ecclesbourne.

Rufford Coll.

V. 2175 , V. $2175 a$, V. 2178, V. 2205, V. 2384. Pinnules narrower than usual. Ecclesbourne.

Rufford Coll.

10,827, 11,618. Tilgate Forest.

Iantoll Coll. 


\section{Genus PROTOPTERIS, Presl.}

[Sternberg, Flora der Vorwelt, Heft vii. 1838, p. 169.]

This generic name was applied by Presl to a tree-fern stem which he had previously figured and described as Lepidodendron punctatum; the plants which he included under Protopteris are compared to living members of the Cyatheacea.

In Corda's "Flora der Vorwelt" eight genera, including Protopteris and Tempskya, are grouped together in the family Protopteridece.

The genus Protopteris is thus defined by Corda, who considerably extends the earlier definition in Sternberg's work ${ }^{1}$ :-

"Caudex arboreus, extus nudus rel radiculis adventivis involutus. Cortex pulvinulis foliorum quaternariis spiraliter positis oblongis ornata; cicatricibus foliorum medio depressis, fasciculo vasorum centrali simplici hippocrepico continuo decoratis, et infra fasciculis rotundis minutis disjunctis 6 rel 8 , et supra fasciculis æqualibus lateralibus vel nullis circumdatis. Radiculæ adventive per totam superficiem distributæ. Cortex medullosa.

Cylindrus lignosus clausus octangularis, angulis rotundatis. Liber externus in fasciculis ansæformibus disjunctis distributus, internus continuus ligno adnatus. Vagina vasorum tenuis. Lignum tenue, radiis medullaribus tenuibus rel nullis percursum; vasis amplis sexangularibus scalaræformibus. MIedulla centralis ampla, parenchymatosa."

The most readily recognized characteristic of the genus is the horse-shoe form of the leaf-trace, as seen on the surface of the petiole scars. Schenk points ont that such a character as this cannot be regarded as very reliable in the determination of treefern stems ${ }^{2}$; but, failing more trustworthy evidence, the pattern of the leaf-trace is certainly a very convenient feature in the identification of fossil forms. Carruthers, ${ }^{3}$ in his paper on a Lower Greensand Protopteris stem, is disposed to agree with Brongniart and Göppert in attaching considerable importance to the form of the petiole bundle.

1 Flor. Vorwelt, p. 76.

2 Foss. Pflanz. p. 46.

3 Geol. Mag. 1865, p. 484. 
We may briefly define Protopteris as follows:-

Stems of tree-ferns characterized by a central rascular cylinder consisting of band-form bundles rariously arranged. The surface of the central axis is corered by spirally arranged leaf scars separated by, and occasionally embedded in, a mass of ramenta and adrentitious roots. The leaf-trace, as seen on the surface of the petiole scars, has a horseshoe-like form which presents certain modifications in the pattern according to the species.

The genus appears to range from the Permian to the Lower Cretaceous.

Without following the example of Heer, Velenorsky, and Staub in adopting the generic name of Dicksonia, I have prorisionally placed Protopteris in the Cyatheacece on account of its resemblance to Dicksonia antarctica, Labill.

\section{1.-Protopteris Witteana, Schenk.}

1871. Protopteris Witteana, Schenk, Palæontographica, rol. xix. p. 226, pl, $\mathrm{xxx}$. figs. 6 and $6 a$.

1874. Protopteris (?) Witteana, Schimper, Trait. pal. vég. vol. iii. p. 526.

1880. Protopteris Witteana, Hosius and Yon der Marck, Palieontographica, vol. xxvi. p. 206.

1883. Protopteris Witteana, Renault, Cours bot. foss. vol. iii. p. 75.

1890. Protopteris Witteana, Staub, Földt. Közl, 1890, p. 230 (German text).

This species is thus defined by Schenk ${ }^{1}$ :-

"Truncus arboreus erectus, inter pulrinos radicibus adrentitiis restitus, petiolorum pulvini oblongi spiraliter dispositi, cicatrices orales, fasciculus fibrovasalis sinuosus cornubus inflexis."

Type. Portions of structureless stems. Collection of Obergerichts director Witte, Hanover.

The type specimen, from the Hastings Sands in the neighbourhood of Hanover, is described as being considerably compressed, with a length of $19 \mathrm{~cm}$. and a breadth of $5 \mathrm{~cm}$. The petiole scars are oval in form, and arranged in a fairly close spiral. The form of the leaf-trace is distinctly shown in many of the leaf-bases; between the latter are sereral scars marking the points of attachment of adventitious roots. Schenk's specimen shows no structure;

1 Palæontographica, vol. xix. p. 226. 
the form of the leaf-trace being the chicf characteristic on which the species was founded.

In the British Museum Collection there are three specimens which I have referred to Schenk's species; two of these are simply casts without any minute structure, but the other is in a much better state of preservation and enables us to amplify the original diagnosis of the speeies.

Stem with a central axis consisting of band-form rascular bundles enclosing a fairly large pith; from these vascular plates branches pass out to the petioles, and in a surface-riew of a leafstalk base the leaf-trace is shown to present more or less clearly the characteristic horse-shoe pattern.

The oral petiole scars are arranged fairly closely; towards the periphery of each is a single vascular bundle of the horse-shoe form, but differing from that of $P$. punctata in the absence of the distinct constriction which occurs in each limb of the leaf-trace; the free upper ends of the leaf-trace are distinctly curved inwards. Sections of adventitious roots occur in the lower part of the petiole scars. Between the leaf-bases there is a mass of filamentous tissue, traversed here and there by irregularly disposed roots.

Before describing in detail the specimens of Protopteris Witteana in the National Collection, it should be pointed out that they appear to differ in no very important characters from the widelyspread $P$. punctata. Possibly the Wealden specimens at present referred to the species instituted by Schenk, may eventually find their proper place under $P$. punctata; but at present we may regard the slight difference in the pattern of the leaf-trace bundles of the two forms as sufficient reason for the retention of Schenk's Wealden species.

In Protopteris punctata, Sternb., we have one of the best known fossil tree-ferns. The species was first instituted by Presl for a plant previously figured and described by Sternberg as Lepidodendron punctatum. ${ }^{1}$ Sternberg's specimen was for some time referred to as having been obtained from Bohemian rocks of Carboniferous age; another example of the same plant from Greenland was regarded by Heer, in the third rolume of the "Flora fossilis Arctica," as indicative of Carboniferous rocks. It was, howerer, shown by Krejci and Feistmantel that the coal-

1 Sternberg, Flor. Vorwelt, Heft i. p. 20. 
bearing strata of Bohemia, from which Sternberg's specimen was obtained, were of Cenomanian age, and this led Heer to correct his prerious statement as to the age of the Disco Island plant beds. ${ }^{1}$

It is to $\mathrm{Cotta}^{2}$ that we are indebted for the earliest information as to the minute structure of the genus Protopteris. In 1836 he described in detail the anatomy of a tree-fern stem, afterwards called $P$. Cotteana, which was found in a boulder in Saxony, but considered to have originally come from Bohemia; this plant agrees very closely with the common form $P$. punctata. The generic name Caulopteris, Lindley and Hutton, is substituted for Protopteris in Güppert's "Fossilen Farrnkrïuter." 3 Carruthers" also prefers Lindley and Hutton's genus as being older than Presl's Protopteris, and more suitable for such tree-fern stems. In Corda's classic work ${ }^{5}$ Sternberg's specimen is further described, and compared to the Cyatheacece; the original name, $P$. punctata, being replaced by that of $P$. Sternbergii. The name Protopteris was originally given to a tree-fern stem possessing a well-defined character in the form of its leaf-trace bundle; on the other hand the generic term Caulopteris was applied to a specimen on which no useful or precise definition could be founded. ${ }^{6}$ If we do not necessarily connect the name of Protopteris with botanical affinity, it is a useful term to retain as pointing to a form of fern stem different to that for which Lindley and Hutton's genus is retained.

In 1865 Carruthers ${ }^{7}$ published a description of a cylindrical sandstone cast of Protopteris punctata from the Upper Greensand of Dorsetshire; the form of the leaf-trace bundles is clearly shown in the original ${ }^{8}$ of Carruthers' figure, and there can be no doubt of its identity with Sternberg's Bohemian type. Unfortunately the English specimen is entirely without internal structure.

The substitution of Dicksonia for Protopteris by certain writers, such as Heer, Velenovský, and Staub, has already been referred to; the same generic name has also been used by Renault for a fossil fern-stem of Cretaceous age from the Ardennes. ${ }^{9}$

1 Flor. foss. Aret. vol. vi. p. 24. ${ }^{2}$ N. Jahrb. 1836, p. 30, pl. i.

3 p. 449. Geol. Mag. 1865, p. 487. ${ }^{5}$ Flor. Vorwelt, p. 77.

6 Lindley and Hutton, Foss. Flora, vol. i. pl. xlii.

7 Loc. eit. p. 484, pl. xiii.

8 Specimen in the British Museum, registered number 39002. The plate illustrating Carruthers' paper hardly does justice to this remarkably fine specimen.

9 Cours bot. foss. vol. iii. p. 74. 
The following list of synonyms of Protopteris punctata shows, to some extent, the distribution of that characteristic type of tree-fern in Lower Cretaceous times: how far we may consider this species identical with, or very nearly allied to, the Wealden form is difficult to determine.

\section{Protopteris punctata, Sternb.}

1820. Lepidodendron punctatum, Sternberg, Flor. Vorwelt, Heft i. p. 20, pl. vi. pt. viii. fig. 2.

1822. Filicites punctatus, Martius, Denkschr. k. Baier. bot. Ges. vol. ii. Abth. i. p. 130.

1825. Lepidodendron punctatum, Sternberg, Flor. Vorwelt, Heft iv. p. xii.

1828. Sigillaria punctata, Brongniart, Prodrome, p. 64.

1828. Sigillaria punctata, Brongniart, Hist. vég. foss. p. 421, pl. exli.

1835. Lepidodendron punctatum, Cotta, N. Jahrb. 1835, p. 326.

1836. Caulopteris punctata, Göppert, Nova Acta Ac. Cæs. Leop.-Car. vol. xvii. (Suppl.), p. 449.

1838. Protopteris punctata, Sternberg, Flor. Vorwelt, Heft vii. p. 170, pl. lxv. figs. 1-3.

1845. Protopteris Sternbergii, Corda, Flor. Vorwelt, p. 77, pl. xlviii.

1845. Protopteris punctata, Unger, Syn. plant, foss. p. 107.

1818. Protopteris punctata, Brown, Index Nomencl. p. 1047.

1850. Protopteris Sternbergii, Unger, Gen. spec. plant. foss. p. 194.

1865. Canlopteris punctata, Carruthers, Geol. Mag. p. 484, pl. xiii.

1866. Protopteris Debeyi, Schlüter, Sitz. niederrhein. Ges. Bonn. p. 68.

1866. Caulopteris punctata, Reuger, Ziva, p. 126.

1869. Protopteris Stembergii, Schimper, Trait. pal. vég. vol. i. p. 706, Atlas, pl. lii. fig. 1.

1870. Protopteris Sternbergii, Roemer, Geol. Oberschles. p. 300.

1872. Protopteris Sternbergii, Feistmantel, Abh. k. böhm. Ges. Wiss. vi. Folg. vol. v. p. 26, pl. ii. fig. 5 .

1875. Protopteris punctata, Geinitz, Palæontographica, vol. xx. p. 304.

1875. Protopteris punctata, Heer, Fl. foss. Aret. vol. iii. p. 8, pl. v. figs. $1-2$; pl. vi.

1880. Protopteris punctata, Hosius and Yon der Marck, Palicontographica, vol. xxvi. p. 205, pl. xliii. figs. 185-186.

1882. Dicksonia (Protopteris) punctata, Heer, Fl. foss. Aret. vol. vi. p. 24, pl. xlvii.

1882. Protopteris punctata, Schmalhausen, Schrift. Kiew. nat. Ges, vol. ri. pt, ii. p. 216, pl. viii.

1883. Protopteris Sternbergii, Renault, Cours bot. foss. vol. iii. p. 75.

1888. Dicksonia punctata, Velenorský, Abh. k. böhm. Ges. Wiss. vii. Folgr vol. ii. p. 20 , pl. v. figs. $2-4$.

1890. Dicksonia punctata, Staub, Földt. Közl. vol. xx. p. 227. 
Stenzel ${ }^{1}$ has referred to several Protopteris species in his important communication on Rhizodendron Oppoliense, Göppert; he points out that $P$. Cottai should be regarded as a synonym of $P$. Cotteana, Presl, and refers the specimen described in 1865 by Göppert ${ }^{2}$ as $P$. Sternbergii to a new species, $P$. fibrosa, Stenz.

\section{Protopteris Witteana, Schenk.}

\section{Pl. XI.}

The most important specimen of Protopteris Witteana from a botanical point of riew is represented in Pl. XI.; it is in all probability from the English Wealden rocks, but unfortunately the registered number is partly illegible, and cannot be identified with any entry in the IISS. Catalogue of the Geological Collections.

This piece of stem has probably been slightly compressed, and the external surface suggests considerable rolling; it tapers slightly towards both of the bluntly rounded ends. The internal structure is partially preserved, apparently in carbonate of lime, but the details are very imperfectly shown in microscopic sections. On the smooth water-worn surface the petiole bases are seen to be broadly oval in form, and slightly projecting above the general level of the stem; in each leaf-scar the horse-shoe vascular bundle is more or less clearly marked. Fig. $3, \mathrm{Pl} . \mathrm{XI}{ }^{3}$ shows one of the more perfect leaf-trace bundles at $t$, and external to this at $s$ the peripheral sclerenchymatous tissue of the petiole; such a form agrees more closely with that of Protopteris Witteana as figured by Schenk, than with the more constricted form of $P$. punctata. In the immediate neighbourhood of the leaf-trace there are a few small circular markings, and occasionally these show two concentric circles, as at r.r. in Fig. 3 ; the inner no doubt representing the vascular axis, and the outer the peripheral limits of an adrentitious root. In the same Figure at $r^{\prime} \cdot r^{\prime}$. there are oblique longitudinal sections of adventitious roots. In some of the leaftrace bundles it is possible to see clearly the peripheral stereome tissue of the petiole base, which weathering agencies hare occasionally left in relief immediately above the upper end of the vascular strand; e.g. at $s$, Fig. 1 .

There is a rery striking resemblance between the more perfectly

1 Jahres-Ber. Schles. Ges. Kultur, 1886.

2 N. Jahrb. 1865 , p. 395.

3 This drawing is made from the ground-down surface of the specimen. 
preserved petiole bases of $P$. Witteana and those of Dicksonic antarctica.

Between the prominent petiole scars the matrix of the fossil is somewhat lighter in colour, as at a.a., Figs. 1-3; this appears to consist of elongated parenchymatous cells, which may possibly have originally existed as multicellular filaments, but have been more or less welded together in the process of mineralization. Here and there in this inter-petiolar tissue traces of adrentitious roots oecur, as e.g. at $r$ and $r^{\prime}$ in Figs. 1-3.

In Dicksonia antaretica the bases of the petioles are separated by a woolly mass of brown threads, traversed by a few adrentitious roots. If these threads (ramenta) be examined microscopically they are found to be made up of long and narrow parenchymatous elements, very similar in shape to those which occur between the petiole bases in the fossil stem.

In Pl. XI. Fig. 2 a transverse section of the fossil stem is represented natural size; the curved band-form vascular plates are clearly shown at $t$, and at $p$ portions of the conlucting tissue are curving outwards as leaf-traces; an impression of a root section is seen at $r$, and at $a$ are the masses of tissue separating the individual petioles.

A small piece of the vascular tissue of the stem is shown in Fig. 4 ; the xylem, $x$, is made up of polygonal tracheides of the scalariform type, and associated with these there are indications of parenchymatous cells; the whole xylem tissue being apparently rery similar in structure to that in the stem of Diclisonia antarctica.

The dark lines, $b . b$, on either side of the xylem no doubt mark the limits of the phloem, but this more delicate tissue has not been preserved.

In a few places there are traces of fairly large brown-walled elements external to the limits of the phloem.

The xylem of this specimen, as regards the arrangement of the rascular bands and their histological structure, is very similar to that of Protopteris Cottai as figured by Corda. ${ }^{1}$

V. 2181. An imperfectly preserved Sandstone cast. Leaf-scars indistinctly shown. Ecclesbourne.

Rufford Coll.

1 Flor. Vorwelt. pl. xlix.

There is a siotion of $P$. Cottai in the Botanical Department Collection (British Museum) cut from the specimen figured by Corda. 
V. 2302. A rery imperfect cast, $23 \mathrm{~cm}$. long; the petiole bases badly defined. A number of small holes occur on the surface of the sandstone, which no doubt mark the position of adventitious roots. The leaf-trace appears to correspond in shape to that of $P$. Witteana as represented in Schenk's figure, Palæontographica, vol. xix. pl. xxx. Ecclesbourne.

Rufford Coll.

\section{Family ? SCHIZACE E.}

Sporangia usually on modified leaf-segments; sessile or shortly stalked, with a complete apical annulus and longitudinal dehiscence.

\section{Genus RUFFORDIA, gen. nov.}

In instituting this new generic name I have followed the example recently set by Raciborski in the case of Mesozoic ferus, and by Stur, Zeiller, Kidston and others in dealing with ferns of Palæozoic age. Raciborski proposes the name $K$ lukia ${ }^{1}$ for the "oldest known of the Schizacece," and takes as the type of the genus Pecopteris exilis, Phill., of which fertile pinnules have been described by Phillips, Lindley and Hutton, and Bunbury.

In the present instance the new term is proposed instead of the older provisional genus Sphenopteris, on the ground that the Museum Collection has afforded material which gires us a much further insight into the true botanical affinity of Dunker's species, S. Gopperti. The fertile pinnæ, described in detail under the species Ruffordia Göpperti, suggest a connection with Anemin, and the character of the sterile fronds is strongly confirmatory. On the other hand no details can be made out in the sporangia, which would afford the most trustworthy kind of evidence in farour of or against a reference to the Schizacees; to refer the Wealden fern to Anemia, or to Dawson's genus Aneimites, would be a step in adrance of the facts at our disposal. Dawson suggested the sub-genus Aneimites for a Devonian fern of the Cyclopteris type, 
which showed fertile pinnæ but no sporangial structure; he compared the sterile pinnules to those of Anemia adiantifolia, $\mathrm{S} w$., from Cuba. ${ }^{1}$ Schimper $^{2}$ does not admit the correctness of Dawson's determination; and, indeed, an inspection of the figures of Cyclopteris (Aneimites) Acadica, Dawson, does not lead one to accept the specimens as evidence for the existence of the Schizacece in pre-Carboniferous times.

The plants included under Ruffordia are all referred to one species, some of the specimens being placed in a variety to denote a marked difference in size of the ultimate segments of the sterile fronds.

The genus is characterized by a distinct contrast between barren and fertile pinnæ, by the resemblance of the pinnules to those of Anemia adiantifolia, Sw., and by the correspondence in habit of sterile and fertile pinnæ to that species.

Ruffordia is placed in the Schizacea, but, in the absence of very satisfactory proof, with the addition of a query expressive of the imperfect evidence.

The adoption of this name is to place on record the enthusiasm and careful work of Mr. Rufford, to whose labours we are indebted for the material on which the genus has been founded.

\section{1.-Ruffordia Göpperti (Dunk.).}

1833. Sphenopteris Phillipsii, Mantell, Geol. S.E. England, p. 239, fig. 2.

1844. Cheilanthites Göpperti, Dunker, Progr. p. 6.

1546. Sphenopteris Göpperti, Dunker, Wealdenbildung, p. 4, pl. i. fig. 6, pl. ix. figs. 1-3.

Sphenopteris Hartlebeni, Dunker, loc. cit, p. 4, pl. ix. fig. 9. Sphenopteris longifolia, Dunker, loc. cit. p. 4, pl. viii. fig. 6.

1848. Sphenopteris Göpperti, Bronn, Index pal. nomencl. vol. ii. p. 1168. Sphenopteris Hartlebeni, Bronn, ibid. p. 1168.

1849. Sphenopteris Göpperti, Brongniart, Tableau, p. 107.

1850. Sphenopteris Göpperti, Unger, Gen. spec. plant. foss. p. 109.

185̃. Sphenopteris adiantifrons, Ettiugshausen, Jahrb. k.-k. geol. Reichs. Jahrg. ii. No. 2, p. 156.

1852. Sphonopteris Jugleri, Ettingshausen, Abh. k,-k, geol. Reichs. Band i. Abth. iii. No. 2, pl, iv, fig. 5 .

1 Quart. Journ, Geol. Soc, vol, xxii. 1866, p. 153.

2 Trait. pal. vég. vol. iii. p. 489. 
1854. Sphenopteris Phillipsii, Morris, Brit. foss. p. 21.

1864. ? Sphenopteris Jugleri, Leckenby, Quart. Journ. Geol. Soc. vol. xx. p. 79.

1869. Sphenopteris (Davalt) Hartlebeni, Schimper, Trait. pal. vég. vol. i. p. 394, pl. xxx. figs. 2 and 3.

Sphenopteris (Davall) Jugleri, Schimper, loc. cit. p. 394.

Sphenopteris (Davall) longifolia, Schimper, loc. cit. p. 394.

1870. Sphenopteris Auerbachi, Trautschold, Nouv. Mém. Soc. Nat. Moscou, vol. xiii. p. 19, pl. xviii. fig. 5.

1871. Sphenopteris Göpperti, Schenk (in part), Palieontographica, rol. xix. p. 209, pl. xxv. figs. $2-5.1$

1875. ? Sphenopteris Jugleri, Phillips, Geol. Yorks. edit. iii. p. 218.

1878. Sphenopteris Göpperti, Dupont, Bull. Ac. R. Belg. sér. ii. vol. xlvi. p. 396.

1881. Sphenopteris valdensis, Heer (in part), Secc. Trab. Geol. Portugal, 4to. 1881, p. 14, pl. xr. fig. 11 [ $v$. Same species under Onychiopsis Mantelli (Brong.)].

1590. Sphenopteris Göpperti, Nathorst, Denkschr. Ak. Wiss. math.-nat. Cl. vol. lvii. p. 43, pl. vi. figs. 2 and 3.

1890. Sphenopteris, sp., Yokoyama, Journ. Coll. Sci. Japan, vol. iii. p. 34, pl. xiv. figs. 13 and $13 a$.

Type. A small, imperfectly preserved pinna. Dunker's type specimen agrees best with those English specimens which have ultimate segments of median size, in length and breadth. The details of venation are not shown in the figure. The following definition is given by the author of the species ${ }^{2}$ :-

"Sphenopteris fronde tripinnata, apicem versus bipinnata, pinnis alternis distantibus vel plus minus approximatis, pinnulis alternis clavatis petiolatis apice laciniatis rel sub-emarginatis, laciniis obovatis, cuneatis, nerris obsoletis, rhacibus tenerrimis canaliculatis."

The Rufford Collection has furnished us with an abundant supply of material, which enables us to extend the definition of the species, and evidence is afforded by some of the specimens of fertile fronds as to the probable botanical affinity of this Wealden fern.

Frond tripinnate-quadripinnate, deltoid or rhomboidal, rachis frequently flexuous, pinnæ alternate, deltoid to ovate-lanceolate; pinnules delicate, decurrent on the rachis, ultimate segments linear acuminate or ovate-cuneate. Venation of the type Canopteridis and

1 Pl. $\mathrm{xxx}$. figs. 2 and $2 a$ regarded as Onychiopsis elongata (Geyl.).

2 Wealdenbildung, p. 4. 
Sphenopteridis. Fructification in the form of scattered sporangia on fertile fronds or pinnæ, of which the leaf lamina is considerably reduced.

Sphenopteris Phillipsii, Mant., may probably be included in the list of synonyms, although the fragment figured under this name is so small that its real nature must remain uncertain. It agrees very closely with some of the more broadly lobed forms of the present species.

There is no doubt as to the specific identity of $S$. Hartlebeni, Dunk., and S. Tongifolia, Dunk., with the present species, as Schenk has already pointed out.

Jeanpautia nervosa, Dunk., ${ }^{1}$ is included by Heer ${ }^{2}$ as a sjnonym of S. valdensis, Hr., but a comparison of the figures lends little or no support to Heer's view. Dunker's J. Brauniana is much more like some of the English specimens of Ruffordia Gopperti than any other forms of that genus.

On comparing Ettingshausen's figure of Sphenopteris Jugleri with those of $S$. Göpperti given by Dunker and Schenk, certain differences are at once apparent, but the inclusion by the latter author of Ettingshausen's species in that of Dunker is fully confirmed by the specimens in the Museum Collection. The specimen from the "Lower Shale" (Yorkshire Oolite) referred by Leckenby to $S$. Jugleri shows a very distinct resemblance to the Wealden fern, and may possibly be rightly included in that species.

An examination of the type specimen in the Woodwardian Museum, Cambridge, suggests a strong likeness to Pl. V. Figs. 2 and 3 of Ruffordia Göpperti (Dunk.); considering the small size and imperfect nature of Leckenby's specimen, it is better to aroid an unqualified assent to its association with the present species.

Schimper includes a species, Sphenopteris (Trichom.) Göpperti, Ettingsh., ${ }^{3}$ under the heading Sphenopteris-Trichomanides, but this was instituted by Ettingshausen, in 1865, under the name Trichomanites Göpperti ${ }^{4}$ for the reception of a plant from the Dachschiefer of Moravia and Silesia. Sphenopteris Göpperti, Dunk., is included by Schimper as a synonym of S. Hartlebeni.

1 Wealdenbildung, p. 12, pl. v. fig. 3.

2 Secc. Trab. Geol. Portugal, 1881, p. 14.

3 Trait. pal, vég. vol. i. p. 412.

4 Sitz. k. Ak. Wiss, Wien. math.-nat. Cl. vol. li. Abth. i. 1865, p. 205. 
The small piece figurer by Trautschold as Sphenopteris Auerbachi, Traut., from the Klin Sandstone seems to be identical with some forms of Ruffordia Gopperti, as first suggested by Schenk." Schenk compares Ruffordia Göpperti with Sphenopteris Stenstrupi, Hr., and S. Minslopi, Old.; his figures represent imperfect pieces of pinnx.

There is no mention of this species by Fontaine in his "Potomac Flora;" one of his species, S. acrodentata, ${ }^{2}$ founded on a very small fragment, seems to be almost identical with the broadest forms of our English species, and especially with such as I propose to consider as Ruffordia Gopperti, var. latifolia. From the small piece figured by Fontaine it is impossible to form any idea of the habit of the fern; the character of the pinna represented by him in fig. 4, pl. xxxiv. seems to be very much the same as that of Thyrsopteris brevipennis, Font., represented in the same plate, figs. 3 and $3 a$; in the former the pinnules are dentate, in the latter entire.

In addition to the specimens figured by Nathorst from Japan as $S$. Göpperti, those fragments described and figured by Yokoyama as Thyrsopteris Kagensis, Yok., ${ }^{3}$ should be compared with the present species; there is no adequate reason for referring them to the genus Thyrsopteris.

Repeated examinations and comparisons of a large number of specimens in the Museum Collection, have led me to regard Ruffordia Göperti as a species of which the regetative parts are extremely variable, and to a much greater extent than the figures hitherto published would lead us to expect. The task of determining, or attempting to determine, what limits to assign to this species has been attended with considerable difficulty, and the conclusion arrived at is one which will doubtless suggest that two or more specifically distinct forms have been included under one name. IIy first inspection of the material favoured the riew of two or three species or, at any rate, varieties; but a more detailed examination forced me to the conclusion that I was dealing with a number of specimens, which could be arranged in a regular and gradually varying series, with a marked difference in form between the extreme types.

1 Palæontographica, vol. xix. p. 261.

2 Potomac Flora, p. 90, pl. xxxiv. fig. 4.

3 Journ. Coll. Sci. Japan, vol, iii. 1890, p. 23, pl. i. figs. 6 and $6 a$. 
Among recent ferns it is well known what striking variations occur in the regetative structures within the limits of a single species. Asplenium may be mentioned as one genus which shows this with sufficient clearness.

In Pl. IV. is reproduced one of the most perfect specimens of R. Göpperti. This is an excellent example of one end of the series, and represents the form of frond which is characterized by fine and narrow ultimate segments.

In Pl. V. Figs. 1-5 we have other specimens of what I regard as the same species. On comparing the figures of Pl. V. with those of Pl. IV. and also Pl. VI. there are sufficiently obvious differences; these, however, consist mainly, if not entirely, in the relative size of the ultimate segments of the pinnx, the general habit being practically identical in the two extreme forms. When a careful survey is taken of a large number of specimens, intermediate forms arrange themselves between the narrow and broadleared types; a few such forms are shown in $\mathrm{Pl}$. V. In a case such as this, where we have no hiatus definite enough to admit of a specific difference, and where we have equally, if not more, striking instances of disparity in the size of leaf divisions among recent ferns, the most reasonable course to follow appears to be that of regarding the several forms as examples of one and the same species. It is but rarely that one district supplies such numerous and well-preserved samples of a local flora as that from which the British Museum material was obtained; and I cannot but think, that to create a number of ill-defined species, on such minor differences as are discoverable in this rich collection, would be to follow a course to which the palæobotanist is too often impelled by the scanty and imperfect data at his disposal.

So far as the barren fronds or pinnæ are concerned there is a striking resemblance as regards habit to Asplenium fragrans, Sw. The variable size and shape of the ultimate segments, which form so marked a feature in the fossil, are still more striking in the recent fern. Under $A$. fragrans Hooker and Baker include a rariety $\beta$. A. feniculaceum, H. and B., which has "narrowly linear" ultimate segments, but the remark is added that "the two rarieties seem to be quite connected by gradual and intermediate gradations." 1 
In the present instance we are not dependent on the uncertain guidance of sterile structures, but are in a position to make use of the raluable eridence of fertile pinnæ. In Pl. III. Fig. 5 we hare an example of $R$. Gopperti which differs from those previously referred to in its smaller size; in Fig. 6 there is the same form, but with the two lowest pinnæ in the fertile condition. In other specimens the whole frond, or pinna, bears sporangia, and agrees exactly with the two basal pinnæ shown in Fig. 6. A close inspection of the fertile branches rereals the existence of sporangia, but without any sign of detailed structure.

Such characters as these are met with in the genus Anemia, and the resemblance is such that I am disposed to regard Ruffordia Gopperti as nearly allied to this member of the Schizacece. There is not only an unmistakable likeness between the fertile branches of Anemia adiantifotia, Sw., and those of the Wealden plant, but an equally strong correspondence in the barren branches and in the habit of the complete frond. This affords another example of the danger of relfing merely on the close parallelism in the form of sterile fronds between fossil and recent ferns. Such a parallelism has been pointed out as regards Asplenium fragrans, Sw., and the present species, but on extending the comparison to the fertile portions of the frond the similarity of the purely vegetative parts is shown to be entirely misleading where botanical affinity is concerned.

If ny determinations be approximately correct, we have in Ruffordia Göpperti an example of a fern much more perfectly preserred than is usual among the fossil representatives of the Filices. In addition to the series of sterile regetatice organs we hare good samples of fertile pinnx, and, in association with these leaf structures, portions of what I regard as rhizomes with the lower parts of petioles still attached: such rhizome fragments are shown in Pl. X. Figs. 1 and 2.

\section{Ruffordia Göpperti (Dunk.).}

\section{2157. Pl. IV.}

These two fronds, or pinnæ, represent one end of the series of rariable forms; the ultimate linear-acuminate segments are uninerred. The habit is compact, and the pinnæ have a more or less deltoid form, with the details distinctly marked as light brown impressions on a homogeneous ironstone. Ecclesbourne. Ruffurd Coll. 


\section{2166. Pl. V. Fig. 1.}

Corresponds closely with $\mathrm{V}$. 2157, but differs in the greater size of the frond, of which this is a fragment, and in the fact that the ultimate segments are slightly broader. Closely associated with the fragments on this piece of rock are portions of what may possibly be the rhizome of the same species. Cf. Pl. IV. (V. 2157) and Pl. V. Fig. $2 b$ (V. 2156). Ecclesbourne.

Rufford Coll.

V. 2156. Pl. V. Fig. 3.

In Fig. $3 \mathrm{~A}$ we have an exceedingly graceful ? frond of roughly pentagonal form and compact habit. It represents a further increase in the breadth of the ultimate segments, but is still entirely in accord with the general character of the species.

Fig. 3B shows part of a large frond with a well-marked flexuous rachis. Cf. Pl. V. Fig. 2(V. 2155a). Ecclesbourne. Rufford Coll.

V. 2155a. Pl. V. Fig. 2.

Very similar as regards breadth of segments to V. 215\%, Pl. IV. The rachis is distinctly flexuous, and the general habit of this and other specimens is strikingly similar to that of Anemia adiantifolia, Sw.

V. 2155b. The reverse piece of V. 2155a. Ecclesbourne.

Rufford Coll.

V. 2243. Pl. V. Fig. 4.

A slight increase is apparent in the breadth of the segments, and some of them appear to be obtusely rounded at the apex rather than acute. In each lobe of the pinnæ are several palmatelyplaced veins. The first glance at this specimen and Fig. 2 of the same plate (V. 2155a) suggests two specific forms, but on close inspection of the two specimens a difference in breadth of the ultimate dirisions appears to be the only real distinction, and, in view of the correspondence in habit, this alone is hardly of sufficient importance to necessitate a separate species. Ecclesbourne.

Rufford Coll.

V. 2731. Pl. III. Fig. 5.

This affords a good example of a small and compact type of ? frond, which differs only in size from the larger and commoner specimens. On the same piece of rock is a piece of rhizome, Pl. X. Fig. 1. Ecclesbourne.

Rufford Coll. 


\section{2295. Pl, III. Fig 6.}

This specimen differs from V. 2731 in haring the lower ? pinnæe in the fertile condition. The leaf lamina is considerably reduced, and the individual sporangia may be made out here and there, but without affording any reliable information as to the character of the sporingial walls. Possibly expression should be giren to the smaller size of this and the preceding specimen by the institution of a new species or rariety, but I am inclined to attach great importance to the fact that such a specimen as V. 2157, Pl. IV. shows the same habit and essential features as these smaller and more delicate forms. There is a distinct resemblance between this specimen and a fertile pinna figured by Fée ${ }^{1}$ as Aneimichotrys aspera from Brazil. Cf. PI. V. Fig. 3A (V. 2156). Ecclesbourne.

Rufford Coll.

\section{2160. Pl. V. Fig. 5.}

This specimen shows very clearly the characters of a fertile pinna. The general habit is much the same as that of $\mathrm{Pl}$. V. Fig. 3. (V. 2156) and other specimens, but in this case, instead of the sharp margins of the pinnules characteristic of the sterile pinnæ, we find a certain ragged appearance in the ultimate segments, and irregular outlines to the blunt lobes. The surface of the pinnules is marked by numerous round projections, which are undoubtedly sporangia; these cover almost the whole surface of the ultimate segments, and, as far as it is possible to decide, closely agree in their manner of occurrence with those of Anemia. Ecclesbourne.

Rufford Coll.

\section{2812. Pl. X. Fig. 2.}

This specimen I regard as part of a rhizome of Ruffordia Göpperti; the surface has a rough appearance suggestive of scaly hairs, and to parts of it are attached the lower portions of petioles. On the same rock occur fragments of pinnæ of this species. Ecclesbourne.

Rufford Coll.

\section{2731. Pl. X. Fig. 1.}

This larger piece of rhizome has already been mentioned in the description of Pl. III. Fig. 5, which occurs in the same piece of ironstone. The surface has the same characteristic roughness 
shown in V. 2812, and here, too, portions of petioles occur attached to the main axis; the piece of frond represented in the figure cannot be traced to the rhizome, but the petiole agrees exactly with such basal portions as are actually attached; there can, therefore, be little or no doubt as to the connection between the rhizome and this frond fragment. The thin and flexuous petioles agree closely with those seen in Pl. V. Fig. 3в (V. 2156) and other specimens. Ecclesbourne.

Rufford Coll.

V. 1069. Breadth of the segments much the same as in PI. V. Fig. 3. Near Hastings.

Presented by P. Rufford, Esq., 1885.

V. 2152. Very similar to V. 1069, but less complete. Ecclesbourne.

Rufford Coll.

V. $2155 c$ and V. 2155d. There is a very close agreement between these two fragments and Dunker's figures of Sphenopteris Göpperti in his Wealdenbildung, Pl. IX. Fig. 1. Cf. also Pl. V. Fig. $3 \mathrm{~A}$ (V. 2156).

V. 2155e. A badly preserved specimen. Cf. Pl. V. Fig. 3в. Ecclesbourne. Rufford Coll.

V. $215 \%$. Of the same type as Pl. V. Fig. 3A (V. 2156), but somewhat smaller. Ecclesbourne.

Rufiord Coll.

V. 216\%. Practically identical with V. 2351. In this specimen and several others there are closely associated fragments of pinnæ, of which the ultimate segments show a marked variation in size; also portions of fertile fronds. Ecclesbourne. Rufford Coll.

V. 2192. One fertile pinna and a portion of a second. The individual sporangia are seen on some of the pinnules. This specimen agrees in all points with Pl. III. Fig. 6 (V. 2295) and Pl. III. Fig. 5 (V. 2731). Cf. also Pl. V. Fig. 3A (V. 2156) and Pl. V. Fig. 5 (V. 2160). Ecclesbourne.

Rufford Coll.

V. 2228. Badly preserved fragments of pinnæ with narrow ultimate segments. $C f$. V. 2157, Pl. IV. Ecclesbourne.

Rufford Coll.

V. 2341. The same as V. 2731. On the same rock is a fragment of Acrostichites Ruffordi, sp. nov. Ecclesbourne. Rufford Coll. 
V. 2351. Agrees with V. 2354, except in the slightly greater brealth of the ultimate dirisions. Venation distinct. Associated with this fragment are others of a much more narrowly segmented form; this juxtaposition on the same rock-surface of pieces of fronds showing considerable difference in the breadth of the pinnules is of common occurrence. Ecclesbourne. Rufford Coll.

V. 2354. Part of a larger frond, with the pinnæ somewhat farther apart than in most cases; the segments are of median breadth and agree closely with the pinnules of other specimens referred to this species. This specimen appears to show the quadripinnate character of the frond.

V. 2354a. Rachis showing sub-opposite and alternate pinnæ; pinnules short and of medium breadth; a more open habit than in most specimens. Ecclesbourne.

Rufford Coll.

The following specimens illustrate various forms of Ruffordic Göpperti (Dunk.), but show no characters other than those to which reference has already been made in the descriptions of more perfect examples.

V. 2151, V. 2152, V. 2153 (several specimens), V. 2156a. Cf. Pl. V. Fig. 3в (V. 2156), also Pl. V. Fig. 4 (V. 2243), V. 2166a, V. 2294. Ecclesbourne.

Rufford Coll.

V. 2877. Fragments of the coarser and finer forms of pinnx. Near Hastings.

Beckles Coll.

\section{2.-Ruffordia Göpperti, var. latifolia.}

As a convenient method of expressing the difference between the extreme forms of this species, characterized by the greater breadth of the ultimate segments, and those with narrowly linear segments, such as the specimen figured in Pl. IV. (V. 2157), I have decided to designate the more broadly-lobed forms by the term latifolia.

V. 2333. Pl. VI. Figs. 1 and $1 a$.

The portion of the frond figured may possibly be a basal pinna. The close resemblance between such specimens as this and Spütro- 
pteris acrodentata, Font., ${ }^{1}$ suggested a reference of the English forms to this Potomac species, but, on carefully looking through the large series of specimens in the National Collections, it is impossible to come to a satisfactory conclusion as to where the line of demarcation should be drawn expressive of specific differences. There is undoubtedly a very marked difference between Pl. VI. Fig. 1 and the specimen represented in Pl. IV., but this is rather a divergence suggestive of two varieties than one to be regarded as of specific value. If we had only these two extreme forms to deal with, there would be no hesitation in speaking of them as distinct species, but, as already pointed out, we have a large number of intermediate forms which, in my opinion, bridge over the apparent gap between the ends of the series.

The chief differences between such specimens as Pl. VI. Fig. 1 and the forms of Ruffordia Gopperti previously described, consist in the greater breadth of the ultimate segments and the more open character of the pinnæ. The venation of the pinnules is very distinctly shown in the figured specimen, Pl. VI. Fig. $1 a$; the veins are flabellately disposed and repeatedly forked; the margin of the pinnules are, for the most part, distinctly dentate. Cf. Fontaine's figure of S. acrodentata, pl. xxxiv. figs. 4 and 4 ; also Mantell's figure of S. Phillipsii.

On the same piece of ironstone, associated with the sterile portions of a frond, occur fragments of small fertile fronds; also several pieces of fronds with the rachis tripinnately branched and showing very little leaf lamina, the serrate divisions of the ultimate branches recalling, to some extent, Omychiopsis Mantelli (Brong.). Possibly these different fragments belong to the same plant, but of this there is no real evidence. Ecclesbourne. Rufford Coll.

V. 2355. The rachis and renation of the pinnules distinctly shown. Very similar to V. 2333, but the segments somewhat narrower. Ecclesbourne.

Rufford Coll.

V. 2158, V. 2327 , V. $235 \%$, V. 2357 . These specimens are regarded as fragments of the same variety. Ecclesbourne.

Rufford Coll.

1 Potomac Flora, p. 90, pl. xxxiv. fig. 4.

2 Geol. S.E. England, p. 239, fig. 2. 


\section{B. Genera which afford no trustworthy evidence as to their affinities with existing families.}

\section{Genus CLADOPHLEBIS, Brongniart.}

[Tableau, 1849, p. 25.]

Brongniart, in his "Histoire des végétaux fossiles," 1 arranged the numerous species of his genus Pecopteris in several groups, and one of these he called Neuropterides. In a later work ${ }^{2}$ this group is reconsidered, with the result that the new generic term Cladophlebis is substituted for those species of Pecopteris included in the Neuropterides. He regards Cladophlebis as a transitional form between Pecopteris and Neuropteris, and points out its characteristics without giving any definite diagnosis.

Fontaine, in his "Potomac Flora," retains Brongniart's genus, and speaks of the convenience of referring certain sterile fronds to such a genus where renation is the guiding character; ${ }^{3}$ he refers to Saporta as the first to put into a concise definition the distinguishing features of Cladophlebis. The following diagnosis is from Saporta's important work on the Jurassic plants of France ${ }^{4}$ :-

"Frons pinnatim divisa, pinnulæ ab alterutra discretæ vel rix inter se cohærentes rachi tota basi adnatie aut plus minusve contractæ subque auriculatæ integræ rariusve dentatæ; nervuli e nervo medio orti apicem versus attenuati rel evanidi primum obliqui, dein curvati furcatoque divisi."

As Saporta remarks, this genus is founded on venation characters and is, therefore, artificial; but like other similarly constituted genera it is useful for the reception of those ferns the botanical affinities of which are at present unknown. This author includes under Cladophlebis the widely distributed Pecopteris Whitbyensis, Brong., Asplenites Rösserti, Schenk, etc.

Schimper, ${ }^{5}$ in 1874, gave a more exhaustive definition of the same genus, and drew attention to the fact that Saporta's de-

1 p. 320.

2 Tableaux, p. 25.

3 p. 67.

Pal. Franç, sér. ii. vol. i. 1873, p. 298.

5 Trait. pal. vég. vol. iii. p. 513. 
scription agrees with that previously given by himself of the group of Jurassic ferns of the t5pe Alethopteris Whitbyensis. Fontaine slightly modifies Schimper's definition, and suggests that with the addition of "midnerve strong at base, and towards the summit dissolving into branches," we have a well-defined group of ferns "strongly characteristic of the Jurassic, and which is fully as much entitled to be called a genus as is Sphenopteris or Pecopteris." 1

In his more recent contributions to the French Jurassic flora, Saporta continues to make use of Cladophlebis as a genus, and adds that the Carboniferous species originally included by Brongniart in his group Pecopteris Neuropteridis, for which the term Cladophlebis was subsequently proposed, have nothing in common with the Liassic and Oolitic species of that genus. The Jurassic species, he observes, give evidence of common characters which point to a well-marked type [Cladophlebis temuis (Brong.), C. Whitbyensis (Brong.), C. ligata (Phill.), C. Haiburnensis (Lindi.), C. lobifolia (Lindl.), and several others, "se ressemblent entre cux et témoignent d'une parenté tenant au moins, à leur physionomie commune "]." Granting the existence of these common characters there is still, as Saporta, indeed, recognizes, no evidence from such traces of fructification as occur of any true relationship ("congénères"); indeed, the fructification, so far as it is known at all, points to the inclusion of ferns of different families under this single generic name.

We may adopt Schimper's definition, with certain modifications : ${ }^{3}$

Fronds pinnately divided, pinnæ spreading, lobes or pinnules attached by the entire base or slightly contracted towards the place of attachment, rarely somewhat auriculate, acuminate, or obtuse, occasionally dentate, especially at the apex, not rarely subfalcately curved upwards, midrib strong at base, and towards the summit dissolving into branches, secondary veins given off at a more or less acute angle, dichotomous a little above the base, and repeatedly dichotomous.

It should be noted with reference to the present genus that Heer ${ }^{4}$ has included under Asplenium those Jurassic ferns which

1 Potomac Flora, p. 67.

2 Pal. Franç. sér. ii, vol, iv. p. 357.

3 Trait. pal. rég. vol. iii. p. 513.

4 Fl. foss. Aret. rol. iv. 1877, p. 38. 
were formerly called Pecopteris, and more recently Cladophlebis; the type of the Jurassic Asplenium being Pecopteris Whitbyensis, Brong. He figures in support of this wholesale removal to Asplenium fragments of fertile pinnules which, so far as the figures indicate, possess a similar arrangement of sori to that of Asplenium (sub-genus Diplazium). ${ }^{1}$ Schenk has also figured fertile pinnules of the same type in the case of an allied form, Asplenites Rösserti.

\section{1.-Cladophlebis longipennis, sp. nov.}

Type. Pinnæe and portion of rachis. Pl. IX. Figs. 1 and $1 a$.

Frond bipinnate, pinnæ long, linear lanceolate, with strong and prominent axes; pinnules separate, slightly constricted at the base, rhomboidal, nervation of the characteristic Cladophlebis type.

The chief distinguishing marks of this species are the shape of the pinnules, and the long gradually tapering pinnæ. Such specimens as occur in the Museum Collection do not throw much light on the general habit of the whole frond.

Dunker's species, ${ }^{3}$ Pecopteris Geinitzii, should be compared with the present species; the two agree to some extent in the form of the pinnules and venation, but in C. lungipennis the pinnæ are much longer, more tapering and graceful than the shorter and stiffer pinnæ shown in Dunker's figure. In the much smaller form figured by Schenk ${ }^{4}$ there is the same kind of likeness in the pinnules, and the pinnæ approach more closely to those of the English species, but, on the whole, there is not sufficient reason to include the latter in the North German form as defined by Dunker.

Ettingshausen and Debey founded a new genus, Dichymosaurus, for the reception of a characteristic type of fern from the Aachen Chalk, and defined it as follows ${ }^{5}$ :-

"Sori duo, dorso medio venarum infimarum utriusque lateris

1 Pl. xxi. figs. 3 and 4.

2 Fl. foss. Grenz. Keup. Lias, p. 51, pl. vii. figs. 7 and $7 a$.

3 Wealdenbildung, p. 6, pl. viii. fig. 3.

4 Palæontographica, vol. xix. pl. xxix. figs. 2 and $2 a$.

${ }^{5}$ Denkschr. k. Ak. Wiss. math.-nat. Cl. rol. xri. 1859, p. 186. 
inserti, orbiculares. Frondes bipinnatæ, dichotomæ. Venæ simplices vel varius furcatæ."

They include this genus in the Gleicheniacee. The nerration appears to be very imperfect, but the median vein is nearly always clear up to the apex of the pinnule. The figures 1,2 and 3 of these authors, and also some specimens figured by Ettingshausen from the Cretaceous beds of Niederschöna, resemble rather closely some of the English examples of Cladophlebis longipennis. ${ }^{1}$ In the absence of any satisfactory evidence in the Aachen species as to affinity with Gleicheniacece, and in the face of certain differences in the arrangement and shape of the pinnules in the English fragments, it is better not to commit oneself to a definite family, but for the present, at least, to retain the provisional name Cladophlebis.

Claduphlebis virginiensis, Font., ${ }^{2}$ shows in some of its pinnules a form and renation rery similar to those of $C$. longipennis, but there is probably no true affinity. Compare also Alethopteris lobifolia, Schimp. (Phill.), Feistmantel, Fl. foss. Gond. rol. ii. 1880 , p. 6, pl. iii. fig. 1 .

The renation of this new species is perhaps hardly of the usual Cladophlebis type; in some respects, e.g. the acute angle at which the lateral veins spring from the midrib, it comes very near to the Sphenopteris pattern, but the habit of the plant and the mode of attachment of the pinnules are characters in favour of some other genus than Sphenopteris.

V. 2204. Pl. IX. Figs. 1 and $1 a$.

This single curved pinna shows very clearly the chief characteristics of the species. The reins are marked on the sancly matrix with special clearness, as shown in the single pinnule, Fig 1a. Ecclesbourne.

Rufford Coll.

V. 1069a. Small pieces of pinna imperfectly preserred. Near Hastings. Presented by P. Rufford, Esq., 1885.

V. 2185 and V. 2185a. In the former part of a single pinna is shown; in the latter a fragment of the main rachis with a pinna given off at a fairly acute angle. Ecclesbourne. Rufford Coll.

1 Sitz. k. Ak. Wiss. Wien. math.-nat. Cl. vol. Iv. Abth. i. 1867, p. 244, pl. i. figs. 1 and 2.

2 Potomac Flora, p. 70, pl. iii. figs. 3-8; pl. iv. figs. 1 and 3-6. 
V. 2197. Portions of seven pinnæ with the rachis very prominent. In many of the pinnules the midrib is fairly well defined, but the renation as a whole is much less distinct than in the figured specimen (V. 2204). Ecclesbourne. Rufford Coll.

V. 2203. Fragments of pinnæ showing distinct renation. In these pieces the central axes of the pinnæ have a well marked longitudinal groove; the indiridual pinnules show the specific characters clearly. Ecclesbourne.

Rufford Coll.

V. 2210. This specimen shows part of the main rachis, and the manner of attachment of the pinnæ. Ecclesbourne. Rufford Coll.

\section{2.-Cladophlebis Albertsii (Dunker).}

1846. Neuropteris Albertsii, Dunker, Wealdenbildung, p. 8, pl. vii. figs. 6 and $6 a$.

1849. Cladophlebis Albertsii, Brongniart, Tableau, p. 107.

1850. Neuropteris Albertsii, Unger, Gen. spec. plant. foss. p. 83.

1853. Newropteris Albertsii, Ettingshausen, Abh. k.-k. geol. Reichs. p. 12.

1869. Alethopteris Albertsii, Schimper, Trait. pal. vég. vol. i. p. 570.

1870. Pecopteris Whitbiensis, ${ }^{1}$ Trautschold, Nouv. Mém. Soc. Nat. Moscow, vol, xiii. p. 27, pl. xix. fig. 2 .

1871. Alethopteris Albertsii, Schenk, Palæontographica, xix. p. 218, pl. xxvii. figs. 4 and $4 a$.

? Pteris Albertsii, Heer, Fl. foss. Arct. vol. vi. pt. i. p. 29, pl. xvi. fig. 5 .

1883. ? Sphenopteris Aabellifolia, rar. evecta, Tenison-Woods, Proc. Linn. Soc. N.S. Wales, vol. viii. pt. i. p. 94 , pl, ii. fig. 2.

1888. P Pteris Albertini, Velenorský, Abh. math.-nat. Cl. k. böhm. Ges. Wiss, vol. ii. Folg. vii. p. 15, pl. ir. figs. 5-10.

1892. ? Asplenium nebbense, Bartholni, Bot. Tid. Bot. For. Kjörenhavn, p. 18, pl. vii. figs. 3-6.

Type. Single pinna; badly preserved.

Dunker adopts the genus Neuropteris, and defines the species as follows ${ }^{2}:-$

"Neuropteris fronde pinnata (bipinnata?) pinnulis tenuibus oppositis distantibus, sessilibus, oblongis, basi rotundatis rel subcordatis, apice attenuatis, subobtusis; nervo medio crassiusculo,

1 Cf. also Asplenites desertorum, Trautschold, loc. cit. pl. xviii. fig. 7.

2 Wealdenbildung, p. 8. 
venis creberrimis tenuissimis obliquis furcatis; rhachi gracili tereti."

The much more perfect material at present arailable necessitates an extension and modification of the original diagnosis.

Frond bipinnate, rachis flat and broad, pinnæ linear lanceolate, alternate to opposite, pinnules falcate, contiguous, attached by the whole of the broad base, acuminate, margin entire or slightly dentate towards the apex.

Brongniart, in his "Tableau," includes Neuropteris Albertsii, Dunk., among the Wealden plants under the name Cladophlebis Albertsii. Ettingshausen recognized a certain resemblance in Dunker's species to Alethopteris, and adopted that generic name. This change is accepted by Schimper, who remarks on the difficulty of determining the true position of the species from the fragment figured by Dunker.

In 1871 Suhenk $^{1}$ notes the close resemblance of Alethopteris Albertsii, Schimp., to A. Rösserti, Schenk, A. insignis, Lindl., and A. Whitbyensis (Brong.); he figures part of a pinna, which, in spite of certain minor differences, is referred to Dunker's species. The same author ${ }^{2}$ draws attention to the resemblance between Pecopteris Whitbyensis, Brong., as figured by Trautschold, ${ }^{3}$ and Alethopteris Albertsii (Dunk.).

Heer includes several Greenland specimens from the Atane beds under Pteris (?) Albertsii (Dunk.), but they do not all appear to be quite the same as Cladophlebis Albertsii; some of the figures, however, show a close resemblance to this species. The same genus is adopted by Velenorský for a fern figured by him as Pteris Alberlini (Dunk.), from the Bohemian Cretaceous beds. He draws attention to the complete correspondence between the Bohemian species and the specimens described by Heer from Greenland, but is not decided as to the relationship between Heer's species and the original Wealden species of Dunker. Some of Velenorsky"s figures bear a strong resemblance to the English specimens, and might perhaps be included in the synonomy of the species; this is the case with his fig. 10, also figs. 6,7 , and 8 ; but figs. 5 and 9 seem to me rather more like the specimens referred by this author to Pteris

1 Palæontographica, vol. xix. p. 218.

2 1bid. p. 261.

3 Nouv. Mém. Soc. Nat. Moscou, vol. xiii. 1870, pl. xix. fig. 2. 
frigida, Heer, the pinnules of which are longer, stiffer, and less falcate. ${ }^{1}$

Fontaine does not include Cladophlebis Albertsii (Dunk.) among the Potomac plants, but some of the pinnæ which he figures strongly resemble this species. As in the case of Thyrsopteris, there appear to be some exceedingly narrow and ill-defined differences between certain species. In sterile fronds of a type similar to those of $C$. Albertsii it is hardly possible to determine the specific limitations with any certainty; possibly no form of frond is so widely distributed in Jurassic and Lower Cretaceous rocks in all parts of the world.

C. virginiensis, Font., ${ }^{2}$ possesses pinnules a trifle broader and shorter than those of $C$. Albertsii, and with entire margins. In $C$. denticulata, Font., ${ }^{3}$ there is a rery distinct resemblance to $C$. Albertsii, but the fragments on which the species is founded are too small to enable us to form an opinion as to the frond as a whole.

C. falcata, Font., ${ }^{4}$ is another fern of very similar form, but it suggests a larger frond than that of $C$. Albertsii and differs in the lobed margins of some pinnules; it is difficult to separate some of the figures of $C$. virginiensis, Font., from those of $C$. falcata, Font. In describing the former species Fontaine remarks that "The Potomac plant is strikingly like Brongniart's Pecopteris Thitbiensis and $P$. tenuis, and one may well hesitate to separate them." s There is also the following remark with reference to the same species which might be applied, in principle, to other ferns from the Potomac beds:- "It does not, however, seem proper to make the Potomac plant an Asplenium so long as it shows no fructification." Another species, C. acuta, Font., ${ }^{6}$ has the same type of frond as C. Albertsii and other ferns; it is spoken of as "more like Dunker's Neuropteris Albertsii . . . . than any other preriously described fossil, and is no doubt quite near the Wealden species." The same species is compared also to Heer's Pteris Albertsii and Schenk's Alethopteris Albertsii. The resemblance

\footnotetext{
1 Abh. k. böhm. Ges. Wiss. math.-nat. Cl. vol. ii. Folg. 7, 1888.

2 Potomac Flora, p. 70, pl. iii. figs. 3-8; pl. iv. figs. 1 and 3-6.

3 Ibid. p. 71, pl. iv. fig. 2 ; pl. vii. fig. 7.

4 Ibid. p. 72, pl. iv. fig. 8 ; pl. $\nabla$. figs. 1-6, etc.

5 Ibid. p. 71.

6 Ibid. p. 74, pl. v. fig. 7 ; pl. vii. fig. 6, etc.
} 
between this Potomac species and the English specimens is certainly striking; in the former there seems to be no sign of any denticulate character in the pinnules; on the whole they ought, I think, as Fontaine has decided, to be kept separate. Finally, C. inclinata, Font., ${ }^{1}$ resembles some portions of C. Albertsii fronds.

It should be remembered that the material included in the British IIuseum Collection which I have referred to C. Albertsii, under a modified definition, is much more perfect than that at the disposal of previous writers; it is not surprising, therefore, that some of the species which have been founded on isolated fragments are brought into close connection with one another by the examination of the fronds of the English specimens.

It would not be difficult to point to various specimens from different parts of the world which can with difficulty be separated from the present species; this applies to such forms as are represented by Cladophlebis Whitbyensis, Brong., and others. The figures given by Oldham and Morris of Pecopteris (Alethopteris) Indica, O. and M., ${ }^{2}$ appear to be very similar indeed to some of our specimens of $C$. Albertsii; and if such a pinna as the one figured in pl. xxvii. fig. 3 were found in European Wealden rocks I should have no hesitation in referring it to Dunker's species. Oliham and Morris recognized the great difficulty in attempting to separate such forms as Pecopteris Whitbyensis, P. dentata, Göpp., $P$. nebbensis, Brong., and several other similar species. ${ }^{3}$ Another example of this close resemblance between portions of sterile fronds, which come under the provisional designation Cladophlebis, is afforded by the fragment figured by Saporta ${ }^{4}$ as $C$. Rösserti, Schenk; this agrees closely with C. Albertsii. Sphenopteris flabellifolia, var. erecta, Ten.-Woods, seems to be very like $C$. Albertsii, if not identical. A specimen in the British Museum (41417) from the Douglas Rirer Coal-seam in Tasmania is probably identical with this Wealden species of Cladophlebis. Possibly, as suggested in the synonomy, Asplenium nebbense (Brong.), figured by Bartholni from the Jurassic rocks of Bornholm, may be regarded as a fragment of Cladophlebis Albertsii.

The specimens from the English Wealden beds show no traces

1 Potomac Flora, p. 76, pl. x. figs. 3-4; pl. xx. fig. 7.

2 Foss. Fl. Gond. vol. i. ser. ii. pt. i. 1863, p. 47, pl. xxvii.

3 Ibid. p. 48.

4 Pal. Franç. rol. i. 1873, pl. xxxi. fig. 4. 
of fructification, and therefore the genus Cladophlebis has been retained. The comparison of these sterile fronds with those of recent ferns is of no great value, especially in such a case as this, where the form of frond has no very distinctive features; but, without wishing to attach any importance to the resemblance, there is a marked similarity between such a specimen as Pl. VIII. (V. 2794) and Onoclea Struthiopteris, Hoffm, ${ }^{1}$ the strong flat rachis, the angle at which the pinnæ are given off, and the more or less falcate pinnules, all agreeing fairly closely.

The common species Cladophlebis Whitbyensis (Brong.), to which reference has already been made, has been placed by some authors in the genus Pteris; by others referred to under the name Asplenium; and, more recently, assigned by Raciborski to the Osmundacee. It is better, I am inclined to think, to regard this Jurassic species as representing a certain widely spread type of frond, which, in all probability, includes under the same name plants which would be referred to different genera and species had we the necessary data to guide us. C. Whitbyensis (Brong.) is an excellent example of a Mlesozoic fern of doubtful affinity with an unusually wide geographical range; it is of very similar habit to C. Albertsii (Dunk.).

The following are some of the records of $C$. Whitbyensis and allied forms illustrating the cosmopolitan nature of this particular type of frond:-

\section{Cladophlebis Whitbyensis (Brong.). ${ }^{2}$}

England. Alethopteris Whitbyensis, L. and H., Foss. Flor. pl. cxxxiv.

France. Cladophlebis Rösserti, Saporta, Pal. Franç. sér. ii. vol. i. 1873, pl. xxx. fig. 4.

Germary. Asplenites Rösserti, Schenk, Fl. foss. Grenz. Keup. Lias, pl. vii. figs. 6 and 7 ; pl. x. figs. 1-4.

Hungary. Alethopteris Whitbyensis, Göpp. Andrae, Abh. k.-k. geol. Reichs. vol. ii. Abth. iii. No. 4, p. 32.

SwEDen. Cladophlebis (nebbensis var.) Rösserti, Nathorst, Sver. Geol. Undersökn. 8vo. 1878. Fl. Höganäs. pl. ii. fig. 1.

Bormiorm. Asplenium Rösserti, Bartholni, Bot. Tid. Bot. For. Kjövenhavn, 1892, vol. xviii. Heft i. pl. vi. figs. 4-6, pl. vii. figs. 1-2. Asplenium nebbense, Bartholni, loc. cit. pl. vii. figs. 3-6.

1 Luerssen includes Struthiopteris Germanica, Willd, as a synonym of Onoclea Struthiopteris, Hoffm. See Rabenhorst's Krypt. Flora, vol. iii. 1889, p. 485.

2 Hist. vég. foss. p. 321, pl. cix. figs. 2-4. 
Russia. Asplenium Whitbiense, Schmalhausen, Mém. Ac. Imp. St. Pétersbourg, vol. xxvii. sér. vii. 1880, pl. xi. figs. 1-10.

Persia. Pecopteris Whitbiensis, Scheuk, Bib. Bot. Uhlworm und Haenlein, vol. vi. 1887.

India. Alethopteris Whitbyensis, Feistmantel, Foss. Fl. Gond. vol, ii. 1880, pl. iii. figs. 1-4, etc.

Chrva. Asplenium Thitbyense, Schenk, Richthofen's China, rol. iv. pl. xxxi.

Asplenium argutulum, loc. cit. pl. xlvii. fig. 1 .

JaPAx. Asplenium Thilbiensis, Yokoyama, Journ. Coll. Sci. Japan, vol. iii. 1890, pl. iii. fig. 3 ; pl. x. fig. 1 and $2 a$.

Asplenium argutulum, Geyler, Palæontographica, vol. xxiv. 1877, pl. xxxi. fig. 1.

America. Clud phlebis falcata, C. virginiensis, C. acuta, Fontaine, Potomac Flora, pl. iv. fig. 8 ; pl. iii. figs. $3-8$; pl. v. fig. 7 , ete.

Arrica. Alethopteris, sp. Cf. Asp. Whitbyense (Hr.) and Asplenium. Cf. nebbense, Brong. (Heer), Feistmantel, Abh. k. böhm. Ges.

Folg. vii. vol. iii. 1889, p. 68, pl. ii. fig. 12.

\section{Cladophlebis Albertsii (Dunk.).}

\section{2794. Pl. VIII.}

In this largest example of the species the main rachis has a length of $18 \mathrm{~cm}$., and is broad and flat on the upper surface. The pinnæ are fairly perfect throughout the entire length of the frond. The falcate form of the pinnules is well marked; their margins appear to be entire for the most part, but some show indications of denticulation; the outlines are not very well defined in such a matrix as we have in this specimen. Details of renation not shown. Ecclesbourne.

Rufford Coll.

V. 712. Part of a frond well preserved, with rachis about $12 \mathrm{~cm}$. long. The shape of the pinnules raries considerably from the broadly deltoid and falcate form of the more terminal pinnæe to the long, narrow, and less distinctly faleate pinnules of the larger and more basal pinnæ. The latter come very near the fragment figured by Dunker; Schenk's pinua agrees rather with one of medium size.

Venation distinct and the axes of pinnæe prominent. Margins of the pinnules apparently entire, but in some cases there are traces of denticulation; here, again, the outlines are not rery sharply defined. Ecclesbourne.

Dawson Coll. 


\section{2215. Fig. 9 .}

Portions of two pinnæ attached to a rachis. Pinnules rery distinct and show venation much more clearly than in the larger specimens; the denticulate margin is much more erident in these

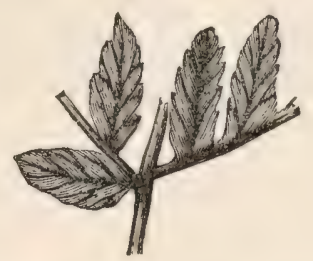

Fra. 9 (V. 2215). Part of four pinnules of Cladophlebis Albertsii (Dunk.). Twice natural size.

pinnules, four of which are shown in the Figure. All of the pinnules have very acute apices, and some are distinctly falcate. Ecclesbourne.

Rufford Coll.

V. 1069b. One of the pinnæ in this specimen is very clearly preserved, and shows in many of the pinnules a distinctly dentate margin near the apex. The distal end of the pinna shows the characteristic broadly serrate form of the segments and their finely pointed teeth; the same characters appear, but much less marked, in some of the pinnæ shown in Pl. VIII. V. 2794. Near Hastings.

Presented by P. Rufford, Esq., 1885.

V. 2175. This small piece of a pinna is one of those specimens about which it is difficult to decide; it has been referred to $C$. Albertsii with some hesitation. Ecclesbourne.

Rufford Coll.

V. 2190. Venation distinct. A fragment of Sphenopteris Fittoni, sp. nov., on the same piece of rock. Ecclesbourne.

Rufford Coll.

V. 2197. The lower part of a frond. Rachis broad and strongly curred. Some of the pinnules show indistinct traces of a dentate margin. Fragments of Onychiopsis Mantelli (Brong.).

V. 2197a. Fragments from lower part of frond. Ecclesbourne. Rufford Coll.

V. 2198. The pinnæ are given off almost at right angles to the rachis, and the pinnules are very closely arranged. Ecclesbourne. 
V. 2202 $a$ and V. 2373. Terminal portions of a frond. Pinnæ opposite or sub-opposite. The rachis appears to be winged. Pinnules alternate, dentate towards their apices, with clearly marked venation.

The larger pinnules are not quite so acutely pointed as in the majority of specimens, but the terminal parts of the pinnæ show the usual serrate form. Cf. the apical portion of V. 2794, Pl. VIII. Ecclesbourne.

Rufford Coll.

V. 2202b. Another terminal piece, but with shorter and more falcate pinnules. Ecclesbourne.

Rufford Coll.

V. 2206. The two specimens with this registered number show pinnules with distinct venation; some of them are falcate and with dentate margin. Here, as in many other specimens referred to this species, there is a variation in the shape of the pinnules, some being falcate, others straight, but all attached to the axis of the pinna by the entire base. Ecclesbourne.

Rufford Coll.

V. 2225. Curved rachis; pinnæ with clearly preserved pinnules showing a distinctly dentate margin. Ecclesbourne. Rufford Coll.

V. 2372. Portion of a frond, $10 \mathrm{~cm}$. long. Pinnules distinct; in some the falcate character is well shown, and in those of the lower pinnæ there are signs of a dentate margin.

V. 2372a. Broad curved rachis. Some of the large pinnules distinctly falcate with dentate margin. Ecclesbourne. Rufford Coll.

V. 2175, V. 2187, V. 2191, V. 2201, V. 2217, V. 2220, V. 2226, V. 2371, V. 2378, V. 2379, V. 2736. Ecclesbourne.

Rufford Coll.

52942. Ecclesbourne. Presented by J. E. H. Peyton, Esq., 1886.

These specimens are referred to the same species, C. Albertsii. Some of the larger pinnæ, e.g. V. 2371, suggest Alethopteris Huttoni, Schimp., ${ }^{1}$ and possibly this species may have to be included as a synonym under $C$. Albertsii (Dunk.).

1 Schenk, Palæontographica, vol. xix. p. 217, pl. xxiv. fig 1. 


\section{3.-Cladophlebis Browniana (Dunker).}

1846. Pccopteris Browniana, Dunker, Wealdenbildung, p. 5, pl. viii. fig. 7 .

1848. Pecopteris Brouniana, Bronn, Index Pal. Nomencl. vol. ii. p. 914.

1849. Pecopteris Browniana, Brongniart, Tableau, p. 107.

1850. Pecopteris Browniana, Unger, Gen. spec. plant. foss. p. 176.

1852. Alethopteris Reicliana, Ettingshausen, Abh. k.-k. geol. Reichs. rol. i. Abth. iii. No. 2, p. 17.

1869. Alethopteris Reichiana, Schimper, Trait. pal. vég. vol. i. p. 569.

1871. Pecopteris Browniana, Schenk, Palæontographica, vol. xix. p. 215, pl. xxvi. figs. 2 and $2 a$.

1874. Alethopteris (?) Browniana, Schimper, loc. cit. vol. iii. p. 502.

Type. Small terminal pieces of pinnæ.

Dunker compares his species to P. Reichiana, Presl, and defines it as follows :-

"Pecopteris fronde pinnata (hipinnata?) pinnis lanceolatis, pinnulis linearibus apice obtusis adnatis, oppositis et alternis, renis tenerrimis obliquis instructis ; rhachi tenui." 1

There are a few specimens in the Museum Collection which agree rery closely with this species, and show certain characters which distinguish them from Cladophlebis Dunkeri, Schimp. They add very little to our knowledge of Dunker's species.

Frond bipinnate, pinnæ alternate or sub-opposite, long, and of uniform breadth; pinnules approximate, obtusely pointed; renation of the Cladophlebis type.

Ettingshausen has followed Dunker's example in comparing Cladophlebis Browniana with Pecopteris Reichiana, Presl, and, indeed, includes the former as a synonym of the latter. Schimiper, in the first volume of his standard work, takes the same riew, but in the third volume he reverts to Dunker's original specific designation.

Schenk, as preriously noted, has probably included under Dunker's species examples of Cladophlebis Dunkeri, but in pl. xxri. fig. 2, Palæontographica, xix. he figures what I regard as a true Cladophlebis Browniana; the bluntly pointed approximate pinnules with entire margins are of rather a different type to that which characterizes the larger pinnæ of $C$. Dunkeri. The latter species is a tripinnate form, but $C$. Browniana appears to be bipinnate.

1 Wealdenbildung, p. 5. 
The pinnæ correspond in character very closely to some of those of Heer's species, Gleichenites Zippei, ${ }^{1}$ Corda, but there is not sufficient evidence to warrant a removal from the artificial genus Cladophlebis.

V. 2198. Pl. VII. Fig. 4.

Long pinnæ of fairly uniform breadth. The margins of the pinnules are entire, and show no signs of subdivision. Venation not very clear, but rather of the Cladophlebis than Pecopteris type. Cf. Gleichenia Zippei, Corda, as figured by Heer from the Lower Cretaceous of Greenland, ${ }^{2}$ also Pecopteris Zippei as figured by Corda in his account of the Lower Cretaceous Bohemian plants, ${ }^{3}$ and Gleichenia Nordenskiöldi, Hr., Fl. foss. Aret. pt. i. pl. i. Ecclesbourne.

Rufford Coll.

V. 2207. The reverse piece of V. 2198.

V. 2204 and V. 2218. Fragments probably of the same species. Ecclesbourne.

Rufford Coll.

V. 2373. Smaller pinnules in these fragments, but evidently of the same type as C. Browniana (Dunk.). Ecclesbourne.

Rufford Coll.

\section{4.-Cladophlebis Dunkeri (Schimper).}

1846. Pecopteris polymorpha, Dunker, Wealdenbildung, p. 6, pl. vii. fig. 5 . Pecopteris Ungeri, Dunker, loc. cit. p. 6, pl. ix. fig. 10.

1849. Pecopteris Ungeri, Brongniart, Tableau, p. 107.

1850. Pecopteris polymorpha, Unger, Gen. spec. plant. foss. p. 177.

Pecopteris Ungeri, Unger, loc. cit. p. 177.

1869. Pecopteris Dunkeri, Schimper, Trait. pal. vég. vol. i. p. 539.

1871. Pecopteris Dunkeri, Schenk, Palæontographica, vol. xix. p. 214, pl. xxvi. figs. 1 and $1 a b$; pl. xxxi. fig. 1.

1975. Pecopteris Brouniana (in part), Schenk, Palaontographica, rol. xxiii. p. 159 , pl. xxvi. figs. $3-5$.

Alethopteris Browniana, Schenk, loc. cit. p. 159.

1 Fl. foss. Arct. vol. iii. 1875 , p. 44 , pls. iv. v. ete.

2 Ibid. loc. cit.

3 Reuss. Verstein. böhm. Kreid. pl, xlix. fig. 2. 
1877. Pecopteris exiliforme, Geyler, Palwontographica, vol. xxir. p. 226, pl. $\mathbf{x x}$. fig. 1.

1878. Pecopteris polymorpha, Dupont, Bull. Ae. R. Belg. sér. ii. vol. slvi. p. 387.

1889. Aspidium Dunkeri, Fontaine, Potomac Flora, p. 101, pl. xxii. fig. 9; pl. xxr. figs. 11 and 12 ; pl. xxri. figs. $2,8,9,18 ;$ pl. liv. figs. 3 and 9.

Pecopleris Browniana (in part), Fontaine, loc. cit. p. 88 , pl. xxiii. fig. 6 ; pl. xxvi. figs. 3 and 13.

1890. Pecopteris exilis, Yokoyama, Journ. Coll. Sci. Japan, vol. iii. p. 35, pl, i. figs, 8-10.

1890. Pecopteris Geyleriana, Nathorst, Denkschr. k. Ak. Wiss, math.-nat. Cl. vol. lvii. p. 48 , pl. iv. figs. 2-6.

Type. Imperfect fragments of pinnæ.

Dunker founded the species Pecopteris polymorpha on a few fragments of a frond from the North German Wealden; some years later Schimper altered the name to $P$. Dunkeri, because Dunker's specific name had been previously used. The following definition of the species by Schimper corresponds closely with the original description as given by Dunker:-

"Fronde bi- vel tripinnata, pinnis patentibus, circa $2-3 \mathrm{~cm}$. longis, alternis; pinnulis inferioribus oblongis repando-incisis, superioribus oblongis, obtusis, approximatis, terminalibus confluentibus; nervis indistinctis; rachi primaria sulcata, rachibus secundariis tenerrime striatis."

I have adopted the generic name Cladophlebis in the absence of any fertile pinnules with characters sufficiently distinct to allow of reference to a genus suggestive of natural affinity.

Frond tripinnate, rachis of medium breadth, pinnxe approximate, alternate and spreading, giving the whole frond a somewhat deltoid form, tapering rapidly towards the apex; pinnules small, entire and somewhat falcate, attached by the entire base, or longer and lobed, and narrower towards the point of attachment; venation indistinct, midrib fairly well marked.

If Schenk's figure of Cladophlebis Dunker $i^{2}$ be examined carefully, it will be seen that the tripinnate character gives place to the bipinnate form in passing from the lower to the upper end of the axis, on the right-hand side of the specimen. The parts towards

1 Trait. pal. vég. vol. i. 1869 , p. 539.

2 Palæontographica, vol. xix. pl. xxvi. fig. 1. 
the upper end are very similar to Schenk's later figures of Pecopteris Browniana, pl. xxvi, figs. $3-5,{ }^{1}$ and, in view of the more perfect nature of the English material, and the additional information it affords as to the character of the fern, I have regarded these specimens as portions of larger pinnæ of $C$. Dunkeri. The figure given by Geyler of Pecopteris exiliforme, from Japan, distinctly resembles $C$. Dunkeri, and does not suggest a plant with a well-marked specific difference.

Fontaine's examples of Aspidium. Dunkeri undoubtedly belong to that species, but the fertile pinnule, pl. xxii. fig. $9 a,{ }^{2}$ on which apparently the reference to Aspidium is based seems hardly sufficient evidence for assuming identity with the recent genus. I have included under C. Dunkeri some of the figures of Pecopteris Browniana given by Fontaine; probably more than those quoted in the abore list of synonyms might be referred to Schimper's species. This inclusion of some of Fontaine's examples of $P$. Browniana, as well as some of those referred by Schenk to the same species, is the result of the more perfect material recently acquired which prores the organic connection of different parts of fronds previously regarded as distinct. Yokoyama, in describing his Japanese plant, adopts Phillips' Jurassic species, $P$. exilis, ${ }^{3}$ for certain fern fragments which I am inclined to consider identical with $C$. Dunkeri; the figure of $P$. obtusifolia, L. and $H .,{ }^{4}$ which is included by Phillips under $P$. exilis, and the pinnæ of the latter species probably represent some other fern than that figured by Yokoyama. His specimens cannot well be separated from the present species. Nathorst compares his species, $P$. Geyleriana, from Japan, with $P$. exiliforme, Gey. (=P. exilis of Yokoyama); this, too, appears to me inseparable from C. Dunkeri. Cf. Nathorst, pl. iv. figs. $2-6,{ }^{5}$ and Pl. VII. Fig. 3 of the present Catalogue. The fragment mentioned by Nathorst as Pecopteris, sp. ${ }^{6}$ is compared by him to $P$. exilis and $P$. Dunkeri.

1 Palæontographica, vol. xxiii.

2 Potomae Flora.

3 Geol. Iorks. p. 210, pl. viii. fier. 16. This species has recently been referred to a new genus, Klukia, Raciborski, Bot. Jahrb. vol. xiii. 1891, p. 5.

+ Fossil Flora, vol, iii. pl, clviii.

5 Denkschr. k. Ak. Wiss. math.-nat. Cl. vol, Ivii, 1890.

6 Ibid. pl. vi. fig. 4. 
In Saporta's species, Scleropteris dissecta, ${ }^{1}$ we hare a similar form of frond to that of $C$. Dunkeri, as regards general outline, but, as Saporta points out in his definition of the genus, the venation is distinct.

The terminal portions of pinnæ which served as Dunker's type for $P$. Broconiana might almost be included in $P$. Dunkeri, but the more perfect specimens figured by Schenk in his earlier contribution to the Wealden Flora make the retention of the species advisable.

\section{237\%. Pl. VII. Fig. 3.}

Portions of large pinnx; pinnules distinct, but venation difficult to determine. Compare this specimen with Schenk's figures 3-5, pl. xxvi., ${ }^{2}$ also Nathorst's figures of Pecopteris Geyleriana, etc. Ecclesbourne.

Rufford Coll.

V. 2185. The two specimens with this registered number have entire pinnules gradually passing into small pinnæ. They show, in places, the habit of $C$. Albertsii (Dunk.), but cannot be separated by any distinct features from other specimens which agree with the typical form of the species. Ecclesbourne.

Rufford Coll.

V. $2193 a$. Same form as the figured specimen V. 2377. Ecclesbourne.

Rufford Coll.

V. 2194. This shows the spreading habit of the frond, and a passage from the bipinnate to the tripinnate form. Details not rery distinct. Ecclesbourne.

Rufford Coll.

V. 2219 and V. 2345. Fragments of pinnæ; both of them agree with Schenk's figure, pl. xxvi. fig. $1,{ }^{3}$ and here the small pinuules are nearly at right angles to the rachis. Some of the pieces, e.g. in V. 2345, differ from such specimens as V. 2377, in having their ultimate divisions smaller and more at right angles to the axes of the pinnæ, but by comparing them with V. 2382, ete., we appear to have a gradual transition to the normal type. There is a difference in the matrix in this case which doubtless has much to do with the apparent divergence in form. Ecclesbourne.

Rufford Coll.

1 Pal. Franç. vol, i. 1873, p. 365, pl. xlviii. fig. 1.

2 Palæontographica, vol. xxiii.

3 Ibid, vol, xix. 
V. 2224. A rery delicate specimen, possibly a young form of C. Dunkeri. Ecclesbourne.

Rufford Coll.

V. 2731. This impression on a sandstone matrix has a different appearance to those specimens preserved in clay or slate, but the differences are, I believe, rather apparent than real; and, considering the effect of a change in the manner of preservation, it would be unwise to institute an additional species. Ecclesbourne.

Rufford Coll.

V. 725. Near Hastings.

Dawson Coll.

V. 1069c. Ecclesbourne. Presented by P. Rufford, Esq., 1885.

V. 2185, V. 2193-cf. V. 2377, Pl. VII. Fig. 3, V. 2195, V. 2208, V. 2212a, V. 2213, V. 2372, V. 2382, show rachis and alternate pinnæ. Ecclesbourne.

Rufford Coll.

3527. Weald. Ifantell Coll. 51404. Tunbridge Wells. Purchased.

\section{Genus SPHENOPTERIS, Brongniart.}

[Mém. Mus. Hist. Nat. Paris, vol. viii. 1822, p. 233.]

Brongniart, in 1822, suggested a subdivision into five sections, or subgenera, of Schlotheim's comprehensive genus Filicites. The name Sphenopteris was proposed by him for those ferns characterized by cuneiform pinnules, with rounded or lobed terminations, and with veins palmately disposed, or radiating from the base of the pinnule.

The fossil taken as the type of this subgenus was S. elegans, Brong. In the "Prodrome d'une histoire des végétaux fossiles," Brongniart defines his genus as follows ${ }^{1}$ :--

"Fronde bi- ou tripinnée; pinnules rétréeies à la base, non adhérentes au rachis, plus ou moins profondément lobées; lobes divergens, presque palmés; nervures paroissant presque rayonner de la base de la pinnule."

The author of the genus points out the comprehensive nature of Sphenopteris, in that a large number of recent fern genera, 
belonging to sereral families, are necessarily included in the definition which he has given. ${ }^{1}$

Since Brongniart's time Sphenopteris has been subdivided by various writers into separate subgenera or genera. In such cases where the subdivision has been founded upon characters which are clearly of taxonomic ralue, the new terms proposed ought to be accepted as useful additions towards a rational classification of fossil ferns. On the other hand, to multiply terms for genera founded on characters admittedly of doubtful value, is hardly calculated to advance our knowledge of the botanical affinities of fossil forms. As an instance of such grouping we may refer to Schimper, ${ }^{2}$ who has instituted sereral types of Sphenopteris, based on resemblances of the purely regetative organs to the fronds of existing genera. Until we know more of the fructification of fossil ferns, it is safer, and more consistent with our endeavours to aroid further unnecessary increase in the list of generic terms, already sadly too long, to make use of such genera as Sphenopteris under the older and more comprehensive sense. As evidence accumulates which is of real value, we shall sooner or later be in a position to make use of those standards of comparison which, in the case of recent ferns, are recognized as the most trustworthy bases for family and generic classification.

For convenience sake the provisional genus Sphenopteris may be defined as follows :-

Herbaceous plants, fronds bi- or tripinnate, venation of the types Sphenopteridis, Ctenopteridis, or Cyclopteridis; pinnules lobed, dentate or entire, tapering towards the point of attachment to the rachis, form varied, but frequently cuneate.

Whilst making use of a definition such as this we must bear in mind that Sphenopteris, as a genus, is founded on general characters, and such as recur in distinct families and genera. Fontaine, ${ }^{3}$ in the "Potomac Flora," has called attention to the provisional nature of this genus; but, unfortunately, in his frequent use of recent generic names there does not always appear to be sufficient data to warrant a departure from the older, if less scientific, terminology.

1 Hist. vég. foss. p. 169.

2 Trait. pal. vég. vol. i. 1869, p. 371.

3 Potomac Flora, p. 89. 
Potonie, ${ }^{1}$ in a recent part of his serial papers on Carboniferous ferns, has promised a revision of the genus Sphenopteris.

\section{1.-Sphenopteris Fontainei, sp. nov.}

Type. Piece of a ? frond. British Mruseum. Pl. VII. Fig. 2. Frond delicate, tripinnate, pyramidal in form; pinnæ alternate, approximate, on a slender rachis; pinnules deeply dissected, ultimate dirisions narrowly linear, with bluntly terminated apices. Venation of Sphenopteridis type.

Under this species a few specimens are included which hare a certain amount of resemblance to the more finely-divided forms of Ruffordia Göpperti (Dunk.), but differ in the much smaller size of the ultimate segments, and in their more compact habit. In the absence of any trace of fructification it will be better to keep the prorisional genus Sphenopteris. Compare the specimens mentioned below with Figs. 5 and 6 (V. 2295 and V. 2731), Pl. III. of Ruffordia Göpperti, also, as regards habit, with Onychiopsis elongata (Geyler); ${ }^{2}$ S. Fontainei suggests, to some extent, the latter species in miniature.

I have ventured to name this species after the author of the "Potomac Flora," who has made such raluable contributions to our knowledge of North American Mesozoic floras.

V. 2155. Pl. VII. Fig. 2.

Part of one side of a ? frond, with the details fairly well shown. Ecclesbourne.

Rufford Coll.

V. 2152. More of the frond shown than in the former specimen, but the details less distinct. Ecclesbourne.

Rufford Coll.

V. 2295. Two specimens rery similar to V. 2155; also the fragments V. 2154 and V. 2358. Ecclesbourne. Rufford Coll.

1 Jahrb. k. preuss. Geol. Landesanst, 1889, p. 21.

2 Pl. II. Fig. 2. For more complete specimens refer to Tokoyama, Journ. Coll. Sci. Japan, vol. iii. pl. ii. 


\section{2.-Sphenopteris Fittoni, sp. nov.}

[Pl. vi. fig. $2 ; \mathrm{Pl}$. vii. fig. 1.]

1836. Sphenopteris gracılis, Fitton, Trans. Geol. Soc. vol. iv. ser. ii. pt. ii. p. 103.

1849. Pachypteris gracilis, Brongniart, Tableau, p. 107.

1852. Pachypteris gracilis, Ettingshausen, Abh. k.-k. geol. Reichs. rol. i. Abth. iii. No. 2, p. 24.

1864. Asplenium palcopteris, Unger, Reise Fregatte Novara, vol. i. Abth. ii. p. 3, pl. i. fig. 4 .

1893. ? Sphenopteris Delgadoi, Saporta, Rer. gen. bot. vol. v. 1893, p. 270, pl. iv. fig. 5 .

Type. Part of a frond. British Museum. Pl. VI. Fig. 2.

Frond ovato-lanceolate, bipinnate; pinnæ linear acuminate, alternate; pinnules alternate, ovate acuminate to deltoid, decurrent, with entire, slightly dentate or deeply lobed margin. Venation of the Sphenopteridis type.

In a paper read before the Geological Society in $1827 \mathrm{Dr}$. Fitton briefly described a Wealden fern from near Tunbridge Wells, which he subsequently figured under the name of sphenopteris gracilis. ${ }^{1}$ At the time when Fitton's paper was read no species of that name had been described, but before his work appeared in the Geological Transactions, Brongniart had referred a Carboniferous fern to the genus Sphenopteris under the name $S$. gracilis.

In a later work Brongniart refers Fitton's species to Pachypteris gracilis. The specimen which Fitton figured as the type of Sphenopteris gracilis is in the Museum of Practical Geolog 5 , Jermyn-street. No doubt the impression has suffered to some extent since 1836; the specimen no longer shows the form of the pinnules with the clearness of outline represented in the figure. The general habit of the frond is, however, faithfully reproduced. In some of the pinnules there are slight indications of a midrib, and an occasional suggestion of dentate margins.

I propose to retain the original generic name Sphenopteris, and, in view of the fact that the term gracilis has been applied to

1 Fitton, Trans. Geol. Soc. vol. iv. ser, ii. pt. ii. p. 103. 
another type of Sphenopteris, it may not be unfitting to adopt the new specific designation S. Fittoni. Dunker refers to Fitton's description of S. gracilis under the head of S. Mantelli, Brong.; ${ }^{1}$ Schenk, ${ }^{2}$ Heer, ${ }^{3}$ and Carruthers ${ }^{4}$ follow Dunker's example in regarding $S$. gracilis as a synonym of $S$. Mantelli. Schimper ${ }^{5}$ also includes Fitton's species under S. Mantelli, and Ettingshausen ${ }^{6}$ mentions Pachypteris gracilis under S. Mantelli.

In the Rufford Collection there are a few specimens, which will be described more fully below, closely corresponding with Fitton's figure, and which demonstrate by their more perfect form the correctness of his opinion that the Tunbridge Wells fern is really a different species from Brongniart's trpe, S. Mantelli.

One of the two species of ferns Asplenium palcopteris, Ung., mentioned in the introduction as described by Unger from New Zealand, comes exceedingly near S. Fittoni. The resemblance is especially striking in the case of Unger's pl. i. fig. $4 ;^{7}$ the other figures are enlarged and, to some extent, restored drawings. The species is compared by its author to Sphenopteris tenera, Dunker, a form now referred to Onychiopsis Mantelli (Brong). It is difficult to understand on what grounds this New Zealand species was named Asplenium, as no trace of fructification appears to hare been found. Possibly it is somewhat rash to absorb Unger's species into one so far separated from it geographically, but the close agreement between the two forms must be advanced in justification of this step.

The specific name palcopteris has, of course, the priority as compared with that of Fittoni, but the fragments on which Unger founded his species were exceedingly small and imperfect, and far inferior to the specimens from which the definition of $S$. Fittoni has been constructed. An additional reason for the adoption of the latter name is the fact that Fitton was the first to deseribe and figure the type specimen, which he called S. gracilis, which term

1 Wealdenbildung, p. 3.

2 Palæontographica, vol. xix. p. 209.

3 Sece. Trab. Geol. Portugal, 1881, p. 12.

4 Geol. Sussex, 1878, p. 282.

5 Trait. pal. vég. vol. iii. p. 469.

6 Abh. k.-k. geol. Reichs. vol. i. Abth. iii. No. 2, p. 24.

7 Reise Fregatte Norara. 
would have been retained had there not been a Carboniferous fern of the same name.

In looking at the specimen (V. 2242), Pl. VI. Fig. 2, and at that figured in Pl. VII. Fig. 1 (V. 2327), or the one with still more deeply lobed pinnules (V. 2327a), Fig. 10, p. 111, we seem to hare two distinct species represented by these extreme forms. A careful examination of the several specimens included under the present species clearly demonstrates a gradual transition from one form to another, and I am unable to draw any satisfactory line between the rarious forms of fronds. The resemblance of certain specimens to species already described from other localities and horizons is pointed out in the deseriptions of the individual fragments. Some of the specimens I was at first disposed to place under Sphenopteris Pichleri, Schenk, ${ }^{1}$ as more perfect examples of that fern than appear to have been arailable when the species was instituted. It is extremely difficult to decide in certain cases whether the better course is to separate specimens by distinct names when they differ in the details of form shown by the ultimate segments, or to include them under one name. Neither plan will lead to final and satisfactory results so long as we have only fragments of sterile fronds and pinnæ to guide us. On the whole the inclusion of these frond specimens in S. Fittoni appears to me the preferable course, which may or may not be justified by the acquisition of more perfect material. In speaking of S. Pichleri, Schenk draws attention to the Hymenophyllaceous appearance of the pinnules; this same filmy character is well seen in some of the English forms of S. Fittoni, especially in the case of V. 2327a, shown in Fig. 10, p. 111. The chief differences between the specimens of $S$. Fittoni, which have some resemblance to S. Pichleri, Schenk, also S. Cordai, Dunk., ${ }^{2}$ and the type specimen figured by Fitton, consist in the more divided pinnules and the more filmy nature of the lamina; the latter character is, however, not very trustworthy, as it may be only apparent and really due to differences in the rock matrix, thus being simply an accident of preservation rather than an original character.

In addition to the species referred to below as resembling in a greater or less degree S. Fittoni, there may be mentioned

1 Palæontographica, vol. xxiii. p. 166, pl. xxix. figs. 2-5.

2 Ibid. vol. xix. p. 210. 
Thyrsopteris incquipinnata, Fontaine, ${ }^{1}$ Sphenopteris Bunburianus, ${ }^{2}$ O. and $\mathrm{M}$., and S. fragilis, Heer.

\section{2242. Pl. VI. Fig. 2.}

The figure of this specimen shows rers clearly the general habit of $S$. Fittoni. The venation of the pinnules cannot be male ont in the figured specimen, which is in the form of a thin carbonaceous impression on a clay matrix; in the ironstone specimens the venation is often remarkably distinct.

The shape of the pinnules is very similar to that in S. plurinervia, ${ }^{4}$ Ifeer, or Scleropteris Pomelli, Saporta, but the resemblance is confiner to details, rather than pointing to a close agreement of the ferns as a whole.

The pinnules of the lower part of the frond shown in the ficure have distinetly serrate or lobed margins. This character becomes much more pronounced in other specimens, which probably represent pinne from the more basal part of a frond. Ecclesbourne.

Rufford Coll.

\section{2327. P1. VII. Fig. 1.}

This specimen is preserved on a fine-grained ironstone, and shows the details of the pinnules much more clearly than V. 2242. So far as it is possible to arrive at a conclusion from the available material I am in favour of including this and similar specimens with those of the form represented in PI. VI. Fig. 2. The greater lobing of the ultimate segments is prohably merely an extension of the marginal indentations referred to in the lower pinne of V. 2242. Ecclesbourne. Ruffurd Coll.

V. $2327 a$. Woodcut, Fig. 10.

II ere the pimnles are still more divided, and the ultimate lobes have a truncate appearance. Length of pinnule about $4 \mathrm{~mm}$. The venation is shown with remarkible distinctness and much more clearly than in the majority of the specimens.

1 Potomac Flora, p. 142, pl. lvii. figs, 3 and 8.

2 Foss. Fl. Gond. vol. i. ser. ii. pt. ii. p. 78 , pl. xxxii. This species is descrilued by Feintmantel as Hymenphyllites Linenduryenus $(O$, and M.).

3 Fl. foss. Arct. rol. iii. 1875 , p. 34, pl. ii. fig. 20.

4 Secc. Trab. Geol. Portugal, 1881, p. 13, pl. xi. fig. 6; pl. xv. fig. 8.

5 Pal. Franç. vol. i. 1873, pl. xlvi. fig. 1. 
The figure gives the impression of a filmy fern, and in the light brown stain on the rock surfuce, representing the leaf lamina, we have just that kind of imprint which might be looked for in a Hymenophyllaceous type of fern. Attention has alrearly been called to the dlanger of trusting too much to such resemblances, which are frequently nothing more than expressions of

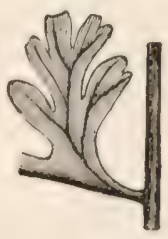

Fia. 10 (V. 2327a). Enlarged 4 times.

the different effects of the diversity in texture and porosity of the rock matrix. The single pinnule shown in the woodcut agrees very closely with one figured by Potonio ${ }^{1}$ in a Carboniferous fern, Sphenopteris Honinghausi, Brong, var. Larischiformis, Pot.; but it is not for a moment suggested that the two species have any natural affinity whatever. Ecclesbourne.

Rufford Coll.

V. 2162. Woodcut, Fig. 11.

Probably a pinna from the basal portion of a frond. Pinnules ovato-lanceolate and lobed. The venation is fairly distinet, but, as is usually the case with carbonaceous impressions on clay, not nearly

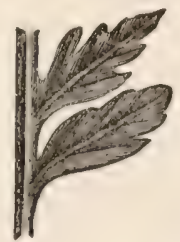

Fra. 11 (V. 2162). Enlarged 3 times.

so well marked as on the ironstone. The figure shows a median, and less marked lateral veins. Some of the pinnules in Fitton's type specimen correspond fairly closely with those represented in

1 Jahrb. k. preuss. Geol. Landesanst, 1890, p. 23, pl. vii. 
the adjoining woodcut. Cf. Unger's figure of Asplenium palaopteris, pl. i. fig. $4,{ }^{1}$ and the fragments of Sphenopteris Delgadoi, figured by Saporta. ${ }^{2}$ Ecclesbourne.

Rufford Coll.

V. 724. Small fragment; probably S. Fittoni. Dawson Coll.

V. 2161. Part of a lower portion of a frond. The pinnules distinctly lobed. This fragment is not unlike S. Pichleri, ${ }^{3}$ Schenk, but in the latter the lobes are described as acute; the small pieces figured by Schenk suggest rather a slender foundation for his species. Ecclesbourne.

Rufford Coll.

V. 2163. A fragment from the upper part of a frond. There are somewhat striking differences between this specimen and V. 2161 and V. 2162, but on comparison with the more complete example, V. 2242, Pl. VI. Fig. 2, there can be little doubt as to specific identity. $C f$. Heer's figure of $S$. plurinervia ${ }^{4}$ from Portugal. Ecclesbourne.

Rufford Coll.

V. 2164. Rachis $12 \mathrm{~cm}$. long. Pinnules indistinctly preserved, but many of them are exactly the same as those of V. 2242, and others agree with the more deeply divided forms such as V. $232 \%$, etc. The pinnæ are given off from the main rachis at almost a right angle. Ecclesbourne.

Rufford Coll.

V. 2190. Part of a frond as an impression on ironstone. This affords another example of what I take to be the effect of the manner of preservation on the general appearance of the fossil. Ecclesbourne.

Rufford Coll.

V. 2352. Here, again, some of the pinnæe are almost at right angles to the main axes: $c f$. V. 2164. There is a certain resemblance to S. Gomesiana, ${ }^{5} \mathrm{Hr}$; ; also to S. Pichleri, Schenk, and, to some extent, to Onychiopsis Mantelli (Brong.).

1 Reise Fregatte Novara.

2 Rev, gen. bot. vol. v. 1893, pl. iv. fig. 5 .

3 Palæontographica, vol. xriii. pl. xxix. figs. 2-5.

4 Secc. Trab. Geol. Portugal, 1881, p. 13, pl. xi. fig. 6, etc.

5 Heer, loc. cit. p. 13, pl. xi. fig. 7. 
V. 2352 $a$. This terminal fragment comes very near to $O$. IFantelli (Brong.), but, if compared with V. 2163, it appears to be linked with $S$. Fittoni by well-defined characters. Ecclesbourne.

Rufford Coll.

V. 2356. Cf. V. 2327; also the terminal part of the frond with the tip of V. 2242.

V. 2356a. Part of a frond. Ecclesbourne.

Rufford Coll.

V. 2183. The two specimens with this registered number must probably be regarded as tips of $S$. Fittoni fronds.

V. 2372. On the same piece of rock is a specimen of Cladophlebis Albertsii (Dunk.). Ecclesbourne.

Rufford Coll.

V. 2878. V. 2882. Fragments. Near Hastings. Beckles Coll.

\section{Genus WEICHSELIA, Stiehler.}

[Palæontographica, vol. v. 1857, p. 74.]

The reasons for which this generic name is substituted for the older and better known term are stated in the description of Weichselia Mantelli (Brong.). Brongniart's genus Lonchopteris, under which $W$. Mantelli has hitherto been included, is defined by him in the "Prodrome" as follows":-

"Fronde plusieurs fois pinnatifide; pinnules plus ou moins adhérentes entre elles à leur base, traversées par une nervure moyenne ; nerrures secondaires réticulées."

Schimper, ${ }^{2}$ in his definition of the same genus, adds "habitu Alethopterideo." This Alethopteris habit is a recognized characteristic of the genus, and is complied with by the species figured by Brongniart in his "Histoire," except in the case of the English and French Wealden forms. ${ }^{3}$ The more perfect and larger portions of fronds from Russia and Germany, which are usually known under the generic title Weichselia, are without the

1 Prodrome, p. 59.

2 Trait. pal, vég. vol. i. p. 620.

3 Pl. exxxi, etc. 
least doubt the same, or some nearly allied plant, as the smaller examples named by Brongniart Lonchopteris IFantelli. When the term Weichselia was proposed it was in ignorance of the fact that the pinnules of the species to which the new name was applied possessed reticulate renation, and would, therefore, come under the older venation genus Lonchopteris. Now that we know more as to the characters of these Weichselia fronds it is seen that, in spite of the resemblance founcled on venation alone, there is a wellmarked divergence from those species which Brongniart's definition of Lonchopteris correctly describes. The generic characters may be stated briefly thus:-

Frond bipinnate, rachis broad and rigid, pinnæ long and with prominent axes, pinnules entire with obtuse apex, attached by the whole of their bases, distinct; venation of the Lonchopteris type.

In the absence of what we may regard as satisfactory evidence for the existence of other species than $W$. IIantelli, I hare included all the Weichselia forms under a single species.

\section{1.-Weichselia Mantelli (Brong.).}

1524. Pecopteris reticulata, Stokes and Webb, Trans. Geol. Soc. vol. i. ser. ii. p. 423, pl. xlvi. fig. 5 ; pl. xlvii. fig. 3.

1825. Pecopteris reticulala, Sternberg, Flor. Vorwelt. iv. p. xx.

1827. Pecopteris reticulata, Mantell, Illust. Geol. Sussex, p. 56, pl. iii. fig. 5 ; pl. iï* fig. 3.

1828. Lonchopteris IIantelli, Brongniart, Prodrome, p. 60.

Lonchopteris Mantelli, Brongniart, Hist. vég. foss. p. 369, pl. cxxxi. figs. 4 and 5 .

1832. Pecopteres reticulata, Passy, Départ. Seine-inférieure, p. 340, pl. xv. figs. 9 and 10.

1833. Lonchopteris Mantelli, Mantell, Geol. S.E. England, p. 244, pl. i. fig. 3.

1836. Polypodites Mantelli, Göppert, Foss. Farrnkrt. p. 341.

1837. Lonchopteris Mantelli, Lindley and Hutton, Foss. Flor. pl. clxxi.

1838. Lonchopteris Mantelli, Sternberg, Flor. Vorwelt. vii. p. 167.

1839. Lonchopteris Mantelli, Mantell, Wonders of Geology, vol. i. edit. iii. p. 371.

1844. Pecopteris sp., Auerbach, Bull. Soc. Imp. Nat. Mosc. 1844, pt. i. vol. xvii. p. 145, pl, v, figs. 10-11.

1845. Pterophyllam Murchisonianum, Güppert, in Murchison's Geol. Russia, rol. ii. p. 501, pl. G, figs. 4-6.

Pterophyllum filicium, Göppert, loc. cit. pl. G, fig. 4. 
1845. Polypodites reticulata, Unger, Syn. plant. foss. p. 93.

Polypodites Mantelli, Unger, ibid. p. 93.

1846. Pecopteris Murchisoniana, Auerbach and Frears, Bull. Soc. Imp. Nat. Mose. 1846, pt. i. vol. xix. p. 495, pl. ix.

18t6. Pecopteris Auerbachiana, Rouillier, Bull. Soc. Imp. Nat. Mosc. 1846, pt. ii. vol. xix. p. 412.

1817. Lonchopteris Mantelli, Mantell, Geol. Excurs. I. Wight, p. 287, fig. 21.

1847. Pecopteris Auerbachiana, Rouillier, Bull. Soc. Imp. Nat. Mose. 1847, pt. i. vol. xx. p. 445.

1S48. Lonchopteris Mantelli, Bronn, Index Pal. Nomencl. vol. i. p. 667.

1849. Lonchopteris Mantelli, Brongniart, Tableau, p. 107.

1850. Polypodites Mantelli, Unger, Gen. spec. plant. foss. p. I66.

Polypodites reticulatus, Unger, loc. cit. p. 166.

1852. Polypodites reticulatus, Ettingshausen, Abh. k.-k. geol. Reichs. vol. i. Abth. 3, No. 2, p. 17.

? Alethopteris recentior, Ettingshausen, loc. cit. p. 16, pl. iii. figs. 17 and 18.

1854. Lonchopteris Mantelli, Morris, Brit. foss. p. 12.

1854. Anomopteris sp., Stiehler, Zeitschr. deutsch. geol. Ges. vol. vi.p. 661.

1855. Anomopteris Ludovice, Stiehler, Ber. Nat. Ver. Harz, p. 14.

1855. Anomopteris Ludovica, Weichsel, Ber. Nat. Ver. Harz, p. 26.

1857. Weichselia Ludovice, Stiehler, Palæontographica, vol. v. p. 75, pls, xii. and xiii.

1865. Pteris reticulata, Ettingshausen, Farrnkrt. Jetztwelt, p. 117.

1868. Weichselia Ludovice, Eichwald, Leth. Ross. vol. ii. sect. i. p. 21, Atlas (Pér. Moy.), pl. i. fig. 2.

1869. Lonchopteris Mantelli, Schimper, Trait. pal. vég. vol. i. p. 623.

Weichselia Ludovice, Schimper, loc. cit. vol. i. p. 599.

?Alethopteris Ettingshausei, Schimper, loc. cit. vol. i. p. 569.

1870. Asplenites Klinensis (in part), Trautschold, Nouv. Mém. Soc. Nat. Mosc. vol. xiii. p. 21, pl. xx. figs. 1 and 5-8.

Polypodites (Lonchopteris) Mantelli, Trautschold, loc. cit. p. 32, pl. xix. fig. 8 .

1871. Lonchopteris recentior, Schenk, Palæontographica, vol. xix. p. 4, pl. i. figs. 2-6.

1871. Weichselia Ludovica, Heer, Neue Denkschr. Schweiz. Ges. Nat. vol. xxiv. p. 5.

1878. Lonchopteris Mantelli, Dupont, Bull. Ac. R. Belg. vol. xlvi. sér. ii. p. 387.

1879. Lonchopteris recentior, Hosius and von der Marck, Palæontographica, vol. xxvi. pp. 201, 209, pl. xlii. figs. $176-179$; pl. xliv. figs. 190-191.

Weichselia Ludovice, Hosius and von der Marck, loc. cit. p. 207, pl. xliii. figs. 187-188; pl. xliv. fig. 189.

1883. Cladophlebis nebbensis, Geinitz, Arch. Ver. Freund. Nat. Meeklenb. Jahr. xxxri. p. 50. 
18९3. Lonchopteris MLantelli, Renault, Cours bot. foss. vol. iii. p. 167.

1888. Teichselia Ludovica, Schulze, Flor. subhercyn. Kreid. p. 14.

1889. Lonchopteris Mantelli, Bristow, Geol. I. Wight, p. 258.

1890. Meichselia erratica, Nathorst, Arch. Ver. Freund. Nat. Mecklenb. Jahr. xliv. p. 1, pl. i. figs. 1 and 2.

1890. Pecopteris Geyleriana (in part), Nathorst, Denkschr. k. Ak. Wiss. math.-nat. Cl. vol. lvii. p. 49 , pl. iv. fig. 3 (not the other figures of this species).

Type. Fragments of pinnæ; pinuules showing renation. The specimens on which the genus Weichselia was founded are much larger, and consist of long pinnæe attached to a broad rachis; no venation shown.

The first diagnosis of Teichselia Ludorica is that given by Stichler in 1857; the earlier definitions of the English species, Lonchopteris Mantelli, were founded on much smaller specimens than those which Stiehler had before him :-

"Frons bipinnata, expansa, maxima (5-6-8 pedalis); rharhis valida, profunde sulcata, apicem versus tenuissime excurrens; pinnæ terminales subrerticales, elongatæ, anguste lineares, remotæ (distantes), reliquæ horizontales, convexæ, approximatæ, linearilanceolatæ, ad 18 poll. usque longæe, $\frac{7}{16}$ poll. latæ, omnes basi discretæ; pinnulæ perbreves, oblongæ, obtusæ, integerrimæ, approximatæ, fructiferæ medio, canaliculatæ, ambitu contractæ, steriles subplanæ." 1

The following definition includes most of the important characters in this peculiar type of fern:-

Frond bipinnate, rachis broad and rigid, pinnæ alternate, rery long, of uniform breadth and with prominent axes; pinnules entire with obtusely rounded apex, a midrib and reticulate secondary veins, oblong, except towards the distal ends of pinnx, where they become more or less triangular in shape and hare pointed apices, attached by the entire base, separate and not confluent; the stiff and thick pinnules are usually inclined towarts the axis of the pinna, and the two rows form with the axis an open $V$ instead of lying in a horizontal position.

The earliest figures and description of Teichsetia IKantelli (Brong.) are usually attributed to Mantell in the year 1824; the paper to which reference is made was written by Stokes and Webb,

1 Palæontographica, vol. v. 1857, p. 75. 
and not by Mantell. These authors recognized the impossibility of determining botanical affinity in the absence of fructification, and placed the Wealden specimens in Brongniart's artificial genus Pecopteris. The figures of Stokes and Webb are reproduced in Mantell's "Illustrations of the Geology of Sussex," and, in addition, there is represented in pl. $\mathrm{i}$. fig. 4 what may be part of a pinna of the same species. There are two figures with the same number; one of these is a leaf of Hymenophyllum Tunbridgense, Sw., but the other is not mentioned in the text, and may be Weichselia Ilantelli.

In Brongniart's "Histoire," 1 there is a figure of a French specimen from Beauvais much larger than the fragments previously figured from the English Wealden. Brongniart draws attention to certain differences between the Wealden form of Lonchopteris and the Carboniferous species of the same genus.

Lindley and Hutton's figure shows a pinna from near Wansford, Northamptonshire, with a length of $6 \frac{1}{2}$ inches; no venation is shown. In speaking of this species in the "Wonders of Geology," Mantell notes its occurrence in Sweden. ${ }^{2}$

In the figure of Pecopteris Murchisoniana given by Auerbach and Frears the pinnæ are represented rather more at right angles to the main rachis than is the case in the English specimen figured in Pl. X. Fig. 3. In 1857 Stiehler described more fully the large specimens of fronds which he had previously referred to Brongniart's genus Anomopteris, and, recognizing several points of divergence from that type of fern, he instituted the new generic term Weichselia.

The fragments figured by Ettingshausen as Alethopteris recentior. are small portions of pinnæ; the pinnules show rery indistinct renation, but it is described as consisting of simple lateral veins at right angles to the midrib; if this be so, the inclusion of A. recentior in the synonomy of Weichselia Mantelli is incorrect. Schenk, from an examination of better material, considers that Ettingshausen's fragments must be referred to Lonchopteris, and admits a difficulty in separating them from the specimens figured by Brongniart and others as Lonchopteris Mantelli. I prefer to follow Nathorst's example and consider Ettingshausen's species synonymous with Weichselia Mantelli.

1 Pl. exxxi, figs, 5 and $5 a$.

2 Wonders of Geology, vol, i. 1839, p. 371. 
In his paper' on the Klin Sandstone Trautschold founds a new species, Asplenites Tlinensis, for certain specimens of fronds which, without any doubt, belong to the present species; his figs. 3 and 4, pl. $\mathrm{xx}$. are less like the ordinary $W$. Mantelli forms, and may be a distinct species, or possibly smaller fronds of the same species. An inclination of the pinnules, similar to that to which attention has been drawn in the definition of the species, is noted in these Russian specimens. In some pinnules, e.g. pl. xx. fig. $7{ }^{2}$ Trautschold represents what he describes as linear projections covering the lateral reins, and which he regards as sori; the renation in this figure is not reticulate, but the fragment is small and imperfectly preserved; in the larger specimens no renation is seen except a well-marked midrib. This author does not accept the name, Weichselin Ludovica, Stiehl., applied by Eichwald to the same specimens which were figured by the former as Asplenites Klinensis, Traut. Another of Trautschold's species, Pecopteris nigrescens, pl. xix. fig. 4, suggests a large form of pinna of similar character to W. Mlantelli ( $c f$. Murchison's "Russia," pl. G, fig. 3).

Hosius and von der Narck refer some small pieces of pinnæ to Lonchopteris recentior; those on pl. xlii. figs. 176-179 ${ }^{3}$ have not the stout prominent rachis which is so characteristic of $\Pi$. MLantelli, and possibly are not correctly referred to that species. The larger portions of fronds represented in pls. xliii. and xliv. are exactly of the same form as the specimen (V. 2630) shown in Pl. X. Fig. 3 of this Catalogue. I have no hesitation in including some (pl. xliv. figs. 190 and 191) of the figures of L. recentior and of Teichsetia Ludovica (pl. xliii. figs. 187-188) under $\Pi$. Irantelli. The frond shown in pl. xliv. fig. $189^{4}$ has no rachis preserved, and the pinnules are longer and narrower than the undoubted examples of this species giren in pl. xliii.

Renault, ${ }^{5}$ in speaking of Lonchopteris Nantelli, agrees with Sehimper that it may belong to the genus Pteris.

In a recent paper by Nathorst a new name, Weichselia erratica,

1 Nouv. Mém. Soc. Nat. Moscou, vol. xiii. 1870, p. 21.

2 Trautschold, loc. cit.

3 Palæontographica, vol. xxri. 1879.

4 Hosius and von der Marck, loc. cit.

5 Cours bot. foss. vol. iii. p. 167. 
is proposed for a plant previously described by Geinitz as an example of Cladophlebis nebbensis (Brong.). In discussing this species Nathorst refers to the characteristic position of the pinnules, and speaks of them as inclined to one another like the wings of a resting butterfly; it is suggested that possibly this inclination of the pinnules towards the secondary rachis may be an adaptation for leading off the rain-water. After noting the reticulated nature of the renation, he suggests the adrisability of retaining the genus Theichselia for the Lower Cretaceous form of Lonchopteris, the latter name being retained for such species as occur in the Coal-Measures." One of the "fertile pinnæ or pinnules" figured by Nathorst in another paper as Pecopteris Geyleriana, Nath., I renture to include under Weichselia Mantelli as a terminal fragment of a pinna. Nathorst also notes this resemblance. ${ }^{2}$

There is certainly, as Brongniart recognized, a distinct difference between such species as Lonchopteris Bricii, etc., ${ }^{3}$ and L. Mantelli, ${ }^{4}$ the former haring the same habit as the genus Alethopteris, but differing in the reticulate venation.

To emphasize the distinctive characters of the Wealden species, I hare retained Stiehler's generic name in preference to Brongniart's genus Lonchopteris.

The form Lonchopteris virginiensis, Font., ${ }^{5}$ from the older Mesozoic strata of Virginia, should be retained in its present genus, as its affinities seem to be rather with the Palrozoic Lonchopteris than with the Lower Cretaceous Weichselia. Stur considers Fontaine's species to be the same as Speirocarpus Haberfelneri, Stur, from the Lunz beds. ${ }^{6}$

V. 2630. Pl. X. Fig. 3, and Woodcut, Fig. 12, p. 120. Only a portion of the specimen shown in the Figure.

This specimen is in striking contrast to the ordinary fragmentary specimens of the species obtained from English localities. Rachis $18 \mathrm{~cm}$. long, very broad and stout, pinnæ alternate, approximate, of considerable length, the longest $20 \mathrm{~cm}$. The general habit of

1 Arch. Ver. Freund. Nat. Mecklenb. Jabr. xliv, 1890, p. 20.

${ }^{2}$ Denkschr. k. Ak. Wiss. math.-nat. Cl. vol. lvii. 1890, p. 49.

3 Hist. vég. foss. pl. exrxi. figs. 2 and 3.

4 Ibid. pl, cxxvi. figs. 4-5.

5 U.S. Geol. Surv. Mon. ri. 1883, p. 53, pl, xxriii. figs. 1-2; p]. xxix. figs. 1-4.

6 Verh. k.-k. geol. Reichs. No. 10, 1888, p. 7. 
the frond is stiff and rigid; the axes of the pinnæ are, like the main rachis, prominent and broad. Pinnules strong and rigid, inclined to the surface of the slab and to the axes of the pinnæ. Venation clearly shown in some of the pinnules, e.g. those enlarged in the woodeut, Fig. 12. Towards the distal ends of the pinnæ, the pinnules become shorter and approach a more triangular or deltoid form, which is, however, more clearly seen in other specimens. Compare the figures of fronds by Stiehler, Trautschold, Hosius and von der Marek, ete.

A somewhat similar habit is seen in Saporta's figure of Scleropteris Pomelii, ${ }^{1}$ but the two species are probably in no sense related. Sussex.

Beckles Coll.

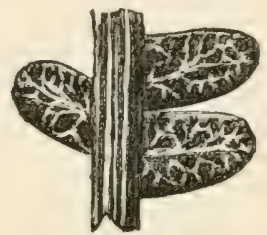

Frg. 12 (V. 2630). Pinnules of Weichselia Mantelli (Brong.). Enlarged 4 times.

V. 2630 a. Part of a frond showing a wide rachis with pinnæ. Sussex.

Beckles Coll.

V. 2173. Fig. 13. Portions of Joung pinnæ, or terminal pieces of older pinnæ showing smaller pinnules about $2.5 \mathrm{~mm}$. in length, and of a different shape to the full-sized segments. Cf. Stiehler, Palæontographica vol. v. pl. xiii. figs. $2 a b$; also a fragment figured by Nathorst in his "Beiträge zur mesozoischen Flora

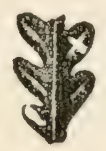

FIG. 13 (F. 2173). Pinnules of Treichselia Mrantelli (Bronr.). Twice nat. size. Japans," pl. iv. fig. 3, which he describes as possibly part of a fertile pinna of Pecopteris Geyleriana (=Cladophlebis Dunkeri), but he recognizes at the same time a resemblance to Weichselia.

1 Pal. Franç. vol. iv. p. 423, pl. 285, fig. 7, and pl. 286, fig. 2 and figs. 6-7. 


\section{V. $2173 a$. Very similar to V. 2173.}

V. 2173b. Fragments of the same form, showing venation. Ecclesbourne. Rufford Coll.

V. 2174\%. Part of a pinna showing very clearly the characteristic inclined position of the pinuules. Cf. Nathorst, Arch. Ver. Freund. Nat. MLecklenb. Jahr. xliv. pl. i. figs. 1 and 2. Ecclesbourne.

Rufford Coll.

V. 2614. Fragments of pinnæ. In one of the pinnæ there is a gradual decrease in size apparent in the pinnules, the smaller and more terminal being more or less triangular in form. Cf. Fig. 13 (V. 2173). Sussex.

Beckles Coll.

V. 2618. One of the pinnæ shows especially well the renation of the thick and leathery pinnules. Sussex. Becliles Coll.

V. 2620. An impression of a secondary rachis, showing rery clearly its thick and stiff character. Sussex.

Beckles Coll.

V. 2636. Part of a long pinna, about $15 \mathrm{~cm}$. Venation distinct. Sussex. Beckles Coil.

12421. A large slab with several fragments of pinnæ; showing in one corner part of a rachis with lateral axes attached. Hastings.

Mantell Coll.

The following specimens, consisting of portions of pinnæ, no doubt belong to the present species:-V. 26, Hastings, purchased; V. 708, Ecclesbourne, purchased; V. 2174: Several specimens showing clearly the reticulately veined pinnules, Ecclesbouine, Rufford Coll.; 2832, 2835, 2837, 2838, 10846, Tunbridge Wells, Mantell Coll.; 51405, purchased 1867; 52942, Ecclesbourme, presented by E. H. Peyton, Esq., 1886. 


\section{Genus T EENIOPTERIS, Brongniart.}

[Prodrome, 1828, p. 61.]

Brongniart defines the genus Teniopteris in his "Histoire" as follows:-

"Folia simplicia integerrima, nerro medio crasso rigido, nerrulis perpendicularibus simplicibus vel basi furcatis. Fructificatio punctiformis." 1

The same author, in his later work, ${ }^{2}$ compares the genus with rarious recent ferns, and notes the resemblance of some specimens of Taniopteris vittata, Brong., to Oleandra; a resemblance which Schimper has given expression to in the case of some Tæniopteroid leaves by the adoption of the name Oleandridium.

In Schenk's definition of Treniopteris, a genus which he places in the Marattiacece, it is described as having "Folia petiolata bipinnata." ${ }^{3}$ Saporta, following Brongniart's original diagnosis, describes the fronds as usually simple, and considerably extends the generic definition ${ }^{4}$ :-

"Frondes plerumque simplices et tunc petiolo valido instructæ (rarius pinnatim compositæ) elongatæ tœniatæ lanceolatæ rel lingulatæ nervo marginali cinctæ; costa media subtus crassa semiteres supra plus minusve gracilis; nervi secundarii plurimi e costa media sub angulo acuto exeuntes mox subito horizontales numerosissimi simplices vel sæpius a basi pluries furcato-dichotomi usque ad marginem nerviformem recto tramite excurrentes. Fructificatio adhuc ignota aut punctiformis, soris punctiformibus totam paginam frondis inferiorem occupantibus."

He remarks that the exact definition of Teniopteris constitutes one of the difficulties of fossil botany. The above diagnosis is more comprehensive than the description giren by some authors of the same genus; the genus Oleandridium of Schenk is included by Saporta under the prorisional and safer name instituted by Brongniart. Attention is drawn to the Treniopteroid form which is oceasionally assumed by the genus Nilssonia, Brong.; but there

1 Hist. vég. foss. p. 262.

2 'Tableau, p. 21.

s Fl. foss. Grenz. Keup.-Lias, p. 99.

4 Pal. Franç. vol. i. 1873, p. 430. 
are certain distinctive features in the renation of the two genera which enable us to distinguish them in most instances. Heer's ${ }^{1}$ figures of Nilssonia orientalis, Hr., probably represent a Teniopteris; the apex of the leaf is like that of T. Beyrichii, Schenk, and the venation corresponds to $T$. Dawsoni, sp. nov.

The genus Oleandridium was founded by Schimper to include ferns with "Frondes simplices, lanceolato-elongatæ rel lingulatæ, coriaceæ. Fructificatio Aspidiacearum?"2 In Zittel's "Palæophytologie" ${ }^{3}$ this genus is described as differing from Teniopteris by its more distinctly horizontal and stronger lateral veins which end in a marginal vein, and by the longer and more elliptical form of the leaf. Another writer ${ }^{4}$ speaks of Oleandridium as comprising those leares of the nerration type Teniopteridis which hare simple laminæ not pinnately divided.

It is unnecessary to suggest that there is a considerable amount of confusion and uncertainty about the two genera, Teniopteris, Brong., and Oleandridium, Schimp. The latter name leads one to suppose some well-established affinity with the genus Oleandra. If specimens with fructification agreeing with that of the recent genus are found they might with adrantage be so named, but to designate such a form of leaf, common among fossil ferns and common in recent genera, by names which imply affinities founded on external form and venation is utterly misleading. In adopting Schimper's genus for a Chinese plant, Schenk ${ }^{5}$ expressly states that he does not mean to convey the idea of a relationship with the recent genus Oleandra, but he makes use of the term Oleandridium for the purpose of indicating a probable difference between the Trniopteroid ferns from Mesozoic and Palæozoic rocks.

It has been shown in a suggestive paper by $\mathbb{W}^{*}$ ite, ${ }^{6}$ that we have a number of Tæniopteroid leares, from rocks of different ages, which may be safely placed in such genera as Dancites and others suggestive of botanic affinity; but in the absence of good evidence, either from fructification on the specimens them-

1 Fl. foss. Arct. vol. v. pl. iv. figs, 4-9.

2 Trait. pal, vég. vol. i. p. 607.

3 Vol. i. p. 133.

4 Solms-Laubach, Fossil Botany, p. 136.

5 Palæontographica, vol. xxxi. 1885, p. 169.

6 Bull. Geol. Soc. America, vol. iv. 1893, p. 123. 
selves, or from the close association of sterile and fertile leares, it is much better to retain the "convenient and non-committal genus Treniopteris."

I propose, therefore, to use the generic term Teniopteris in a wider sense, and in this respect to follow Nathorst, ${ }^{1}$ who has taken the safer course and included under this genus such other generic names as Oleandridium, Angiopteridium, IIarattiopsis, Dancopsis, etc. In taking this riew I am simply following the same plan as in the case of other provisional names such as Cladophlebis, etc. In dealing with such leaf-forms as come under the Tæniopteroid type, it is especially important to wait for trustworthy taxonomic evidence before making use of names which imply close relationship or identity with existing genera; the grounds for this caution are to be found in the numerous recent ferns which have leaves or leaf-segments of the Tæuiopteroid pattern. ${ }^{2}$

In Hooker's "Genera Filicum" ${ }^{3}$ we find the name Teniopteris applied to a recent fern, T. Forbesii, Hook., from Mozambique. Following the example of Fée, ${ }^{4}$ Hooker, in his later writings, includes this genus as a synonym of Vittaria. ${ }^{5}$

We may broadly define Teniopteris as follows:-Frond simple or pinnate, usually lanceolate or linear-lanceolate, apex acute or occasionally obtusely terminated; a well-marked midrib from which lateral reins are given off either at right angles or more or less obliquely; these may be unbranched or acutely forked as they pass towards the leaf margin.

In an allied renation type, Phyllopteris, Brong., the lateral veins are much more oblique, more curred, and repeatedly forked.

The task of naming the rarious fragments of Toniopteris in the Museum Collection has proved a difficult one, and, owing to the meagre nature of the specimens, it is almost impossible to arrive at any very satisfactory or definite results. In none of the examples are there any traces of sori, nor have we any opportunity of obtaining information as to the general habit of the plants, all the fragments being portions of detached leares.

\footnotetext{
1 Srer. Geol. Undersökn. 4to. Flor. Bjuf, 1878-1886.

2 See also Fontaine's species of Anomozamites, Potomac Flora, p. 67.

3 Pl. lxxvi. B.

4 Genera Filicum, p. 85.

5 Species Filicum, vol. v. 1864, p. 176.
} 
If we look over a number of specimens of the recont genus Oleandra, e.g. O. neriiformis, Cav., we find that such characters as the horizontal or inclined position of the lateral reins and the degree of closeness with which these reins are arranged, are by no means constant in the same species, or eren in the same leaf.

In all such examples of the recent genus as I hare seen the apex of the leaf is acuminate, but occasionally in young leaves there appears to be a similar termination to that in $T$. Beyrichii, Schenk. In some forms of Oleandra the leaf apex becomes suddenly and sharply acuminate; if the tip of such a leaf were broken off or bent back we should have an appearance very similar to that represented in Pl. IX. Fig. 3 of the present Catalogue.

The following classification of the Wealden fragments must be regarded as provisional, and not one which rests on a rery sure foundation.

\section{1.-Tæniopteris Beyrichii (Schenk).}

1871. Oleandridium Beyrichii, Schenk, Palæontographica, rol. xix. p. 221, pl. xxix. figs. 6 and 7 .

1874. Oleandridium Beyrichii, Schimper, Trait. pal. vég. vol. iii. p. 514.

1882. Oleandridium (Teniopteris) Beyrichii, Peyton, Quart. Journ. Geol. Soc. vol. xxxix. 1883, Proc. p. 3.

Type. Well-preserved leaf. In the Berlin Collection.

Schenk gives the following definition of the species ${ }^{1}$ :-

"Folia simplicia oblonga integra obtusa leviter emarginata basi

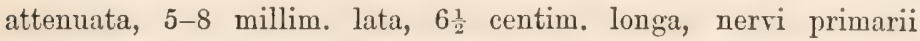
excurrentes, secundarii creberrimi tenuissimi angulo subrecto egredientes dichotomi vel simplices."

Frond simple, linear, entire, apex obtuse and slightly depressed, gradually decreasing in breadth towards the basal end; brealth about $5 \mathrm{~mm}$. and length about $10 \mathrm{~cm}$. Distinct midrib with numerous lateral veins almost at right angles, or somewhat oblique, and suddenly curved inwards towards the frond axis on the upper surface, simple or forked. 
I have slightly modified the original diagnosis in one or two particulars.

Schenk points out that his species is readily distinguished from others by the form of the leaf. There is, however, a fairly close agreement between $T$. Buyrichii, Schenk, and some specimens of T. teminervis, Brauns; ${ }^{1}$ also T. stenoneura, Schenk, as figured by Saporta, ${ }^{2}$ and Taniopteris (Stangerites) spatulata (McClelland). ${ }^{3}$

It is extremely difficult to separate many of the forms of Teniopteris described by rarious writers from different geological horizons.

In 1882 Peyton recorded the discovery by Mr. Damson of a specimen which he referred to Schenk's species, in the Wadhurst clay near Hastings. Other specimens were afterwards found by Peyton himself, who speaks of a slight dirergence of the Hastings specimens from Schenk's figured type. He describes the midrib as "herring-boned"; this I regard as descriptive of the branching outwards of the lateral veins.

V. 2381. Pl. IX. Figs. 3 and $3 a$.

This specimen agrees very closely with Schenk's figure, pl. xxix. fig. 7,4 except that in his specimen the lateral veins are rather closer together.

Cf. T. (Oleandridium) obtusa, Nath., ${ }^{5}$ from the Bjuf plant beds, pl. viii. figs. 7, 9, 10, and 13. It seems almost impossible to separate such a specimen as Fig. 10, Pl. VIII. from T. Beyrichii. Ecclesbourne.

Rufford Coll.

V. 2172. Smaller specimen, $4 \mathrm{~cm}$. long, $4 \mathrm{~mm}$. broad; indented apex. Practically identical with Schenk's figure. Ecclesbourne.

Rufford Coll.

V. 2177. Small fragments of the same species. Ecclesbourne. Rufford Coll.

52942 $a$. Venation not preserred. Possibly a fragment of $T$. Beyrichii, Schenk. Presented by J. E. II. Peyton, Esq., 1886.

1 Brauns, Palæontographica, vol. ix. p. 50, pl. xiii. figs. 1-3.

2 Pal. Franç. vol. i. p. 443, pl. lxii. figs. 2 and 3.

${ }^{3}$ Foss. Fl. Gond. vol. i. pt. i. p. 34, pl. vi. figs. 1-7.

4 Palxontographica, vol xix.

5 Srer. Geol. Undersökn. 4to. Flor. Bjuf, 1878. 
Tæniopteris Beyrichii (Schenk), rar. superba.

The much larger size of some of the specimens and the closer arrangement of the lateral veins have led me to distinguish them from T. Beyrichii, as a definite variety.

Possibly, when better material is discorered, it will be necessary to separate those larger fronds as a separate species; for the present the specimens arailable are hardly sufficiently distinct to admit of more than a convenient descriptive term, such as var. superba.

Saporta has already used the same word as a specific title, but we may use it in this instance in a less precise sense and indicative, at the same time, of a close resemblance to his Jurassic species, T. superba, Sap. ${ }^{1}$

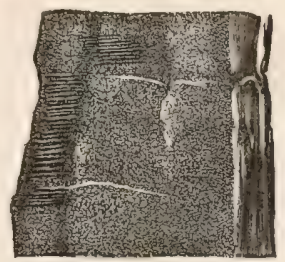

FIG. 14 (V. 2729a). Fragment of a frond of Treniopteris Beyrichii (Schenk), var. superba.

\section{2729a. Fig. 14.}

Thirty-four cm. long; apparently half of the lamina of a large simple froud. On one side of the balf lamina there is the remains of a midrib, from which the closely set lateral reins are given off horizontally. Where small patches of a carbonaceous film occur on the surface of the specimen one can detect very fine lines running between, and parallel to, the lateral veins. Breadth $2.7 \mathrm{~cm}$. at the broadest part. Ecclesbourne.

Rufford Coll.

V. 711. The prominent midrib represented by a deep groove, lateral veins closely arranged. Length of specimen $7.5 \mathrm{~cm}$., $1.2 \mathrm{~cm}$. broad, about the same width as the figured specimen of T. Beyrichii, Pl. IX. Fig. 3, but the veins are much closer and more numerous. Ecclesbourne.

Rufford Coll.

V. 2380. Portion of a large frond. Venation well marked. Cf. V. 2729a (Fig. 14). Ecclesbourne.

Rufford Coll. 


\section{2.-Tæniopteris Dawsoni, sp. nov.}

Type. Portions of simple fronds. In the British Museum. Fig. 15.

In some of the Taniopteris specimens from the Sussex beds there is a form of venation which clearly marks them off from the previous species. I propose to gire expression to this dis. tinctive character by the institution of a new species named after Mr. Charles Dawson, whose name is already well known in connection with Wealden palæontology.

It is quite possible that this species may eventually hare to be regarded as another variety of $T$. Beyrichii.

Frond simple, lanceolate, midrib prominent with closely arranged lateral veins given off at an acute angle and passing straight to the margin without curving or branching.

The fragment figured by Ettingshausen as $T$. zoebingiana ${ }^{1}$ shows oblique lateral veins, but these spring from the midrib at a more acute angle and have a distinctly curved course, thus differing from T. Dawsoni. As Schenk has pointed out, the fragment on

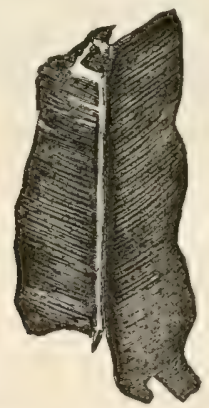

Fig. 15 (V. 2729). Fragment of frond of Taniopteris Darsoni, sp. nor. which Ettingshausen's species was founded is in all probability part of a Neuropteris pinnule; ${ }^{2}$ at all erents it has little claim to be placed in the genus Taniopteris, and none whaterer to represent a new species.

V. 2729. Woodeut, Fig. 15.

On the same piece of rock there is a specimen showing the gradually tapering apical portion of a frond.

1 Abh. k.-k. geol. Reichs. vol. i. Abth. iii. No. 2, pl. iii. fig. 19.

2 Palæontographica, vol. xix. p. 222. 
Lateral veins very regular and numerous. No sign of branching. Cf. Oleandridium Eurychoron, Schenk, Palæontographica, vol. xxxi. 1885, p. 168, pl. xiii. figs. 3-5 and pl. xr. fig. 2. Ecclesbourne.

Rufford Coll.

V. 2383. Fragment showing the same type of renation. Fairlight.

Rufford Coll.

\section{Genus SAGENOPTERIS, Presl.}

[Sternberg, Flora der Vorwelt, vii. 1838, p. 164.]

The genus is thus defined in Sternberg's Flora:-

"Frons pinnata, pinnis ternatim rarius binatim compositis. Venæ tenuissimæ, ramosissimæ, æquales, in maculas irregulariter hexagonoides elongatas confluentes. Costæ crassæ usque ad apicem pinnularum excurrentes."

Schimper ${ }^{1}$ speaks of Sagenopteris as having no analogue among living plants, but notes the obrious resemblance to Nlarsilea; this, howerer, he does not regard as evidence of natural affinity. Stomata have been found on the lower surface of Sagenopteris, but, according to Schimper, there are none on the lower surface of Marsilea leares.

This argument is dismissed by Nathorst, who has obserred stomata in the lower epidermal layer of MIarsilea; but the fructification of Sagenopteris has been adduced as stronger evidence than the mere external resemblance in the leaves of the two plants. The so-called sporocarps are described by Nathorst ${ }^{2}$ as abundant in the Rhætic beds near Pålsjö; they cannot be referred to Conifers or Cycads, and, in the absence of Angiosperms, Nathorst is driven to regard them as the fructification of a Marsileaceous plant, and, therefore, of Sagenopteris, as the only genus that can be included in the Marsileacece. The same conclusion was independently arrived at by Heer after examining the Swedish specimens. ${ }^{3}$

1 Trait. pal. vég. vol. i. p. 640.

2 Foss. Fl. Schwedens, p. 18.

3 Nathorst, loc. cit. p. 18. 
Similar bodies have also been described by Zigno ${ }^{1}$ from the Italian Oolitic strata, but his figures are anything but convincing. Schimper, in Zittel's "Handbuch," 2 considers there can scarcely be a doubt that we must regard Sagenopteris as a genus of the Rhizocerpea, and very near to Marsilea. As Solms-Laubach ${ }^{3}$ has shown, the arguments on which this reference of Sagen pteris to the Marsileacere is based are far from satisfactory.

The two leaf fragments figured by Feistmantel ${ }^{4}$ from the Karharbári beds of India as Sagenopteris (?) Stoticzana, Feist., have surely very little claim to be included in Presl's genus. We may define the genus as follows:-

Leaves with long stalk, bearing at the apex four palmatelyplaced leaflets; leaflets vary considerably in shape and size in the sereral species and on the same leaf, asymmetrical, linearlanceolate, spathulate, orate, etc.; venation reticulate, the meshes elongated in the direction of the long axis of the leaflet; towards the basal end of the leaflets there is often a fairly well-defined midrib which rapidly splits up into a number of anastomosing branches as it passes towards the apex of the leaflet. Fructification in the form of oval or spherical bodies bearing sporangia.

\section{Sagenopteris Mantelli (Dunker).}

1846. Cyclopteris Mantelli, Dunker, Wealdenbildung, p. 10, pl. ix. figs. 4 and 5 .

1849. Adiantites Mantelli, Brongniart, Tableau, p. 107.

1850. Cyclopteris Mantelli, Unger, Gen. spec. plant. foss. p. 95.

1852. ? Cyclopteris Mantelli (in part), Ettingshausen, Abh. k.-k. geol. Reichs. vol. i. Abth. iii. No. 2, p. 13, pl. iii. fig. 15.

1869. Aneinidium Mantelli, Schimper, Trait. pal, vég. vol. i. p. 486.

1871. Sagenopteris IIantelli, Schenk, Palicontographica, vol. xix. p. 222, pl. xxxi. fig. 5 .

1874. Aneimidium Mantelli, Schimper, Trait. pal. vég. vol. iii. p. 486.

1886. ? Thinnfeldia variabilis, Velenovský, Gymn. böhm. Kreid. p. 6, pl. ii. figs, 1-5.

1890. ? Sagenopteris, sp., Yokoyama, Journ. Coll. Sci. Japan, rol. iii. p. 38, pl. $x$. figs, 3 and $3 a$.

1 Flor. foss. Oolit. vol. i. p. 186, pl. xx.

2 Vol. i. p. 154.

3 Fossil Botany, p. 182.

\& Foss. Fl. Gond. vol. iii. 1881, pt. i. (1879), p. 18, pl. xiii. fig. 4. 
Type. Detached leaflets of various shapes and sizes.

Dunker defines his species as follows ${ }^{1}$ :-

"Cfclopteris fronde ... pinuis crassis subpetiolatis, oblique cordatis vel cuncato-subrotundis rel ovato-obtusis integris vel subcrenatis, nonnullis apice sinuatis et bilotatis, nervis creberrimis flabellatis apicem versus irregulariter dichotomis."

The Wealden specimens enable us to give a more complete diagnosis of the species.

Leaf consisting of four leaflets sessile on the apex of the leafstalk, palmately arranged, variable in shape and dimensions, the two upper or terminal leaflets larger than the lower pair, spathulate, obovate or elliptical, margin entire, or with one or two broadly rounded lobes.

Venation reticulate, the meshes elongated in the direction of the long axis of the leaf; in some leaflets there is a fairly distinct midrib near the point of attachment, but it rapidly dies out towards the apex; in some specimens no sign of a midrib. Fructification unknown.

Dunker's figures ${ }^{2}$ of detached leaflets, if we accept his view that they all belong to the same species, sufficiently demonstrate the wide limits within which their form and size vary.

The small specimens figured by Ettingshausen ${ }^{3}$ agree much more closely with Aneimidium Elipsteini (Dunk.), and, indeed, he includes that species as a synonym of Sagenopteris Mantelli (Dunk.). Possibly, as suggested in the above list of synonyms, one of the leaflets is that of the present species, but it is by no means certain that any of them should be included under the genus Sagenopteris.

Schenk ${ }^{4}$ points out the close connection between Sagenopteris Mantelli (Dunk.) and S. rhoifolia, Presl; it seems, indeed, almost impossible to draw any distinct line between these two species. As a rule the leaflets of the former are smaller and less elliptical or elongated than those of the latter, but it is quite conceirable that the discorery of more Wealden specimens may compel us to recognize more definitely this close agreement between the two forms.

1 Wealdenbildung, p. 10.

2 Loc. cit. pl. ix. fig. 4.

3 Abh. k.-k. geol. Reichs. vol. i. Abth. iii. No. 2, p. 13.

4 Palæontographica, vol. xix. p. 223. 
In Velenorsky's contribution to our knowledge of the Gymnosperms of the Bohemian Chalk formation there are several figures of what he calls Thinnfeldia variabilis, Vel.; the characters displayed by this species appear to me identical with those of the larger leaflets of Sagenopteris Mantelli. There is the same venation, the same form of leaflet, and an equally marked variation in shape and size: $c f$. Velenorsky's figures ${ }^{1}$ and $\mathrm{Pl}$. IX. Figs. 4 and 5 of this Catalogue.

Why the genus Thinnfeldia, Ett., should have been chosen is a question not readily answered; no mention is made of a resemblance to Sagenopteris, and there is a great dearth of references and synonomy, which is apparently not unusual in this author's palæobotanical contributions. The definition given of this Bohemian species, which is classed under the Gymnosperms as "species incertie sedis," describes correctly the characters of Sagenopteris Mantelli leaflets. The species is compared to Thinnfeldia Lesquereuxiana, Heer; ${ }^{2}$ but this Greenland fossil has quite a different form, it shows a distinct midrib, and has no reticulate venation: the connection is not obvious.

Hosius and Von der Marek ${ }^{3}$ have figured a leaflet of Sagenopteris from the Neocomian Sandstone of the Teutoberger Wald under the name S. Neocomiensis, Hos. and V. d. Marck; this species closely resembles S. Mantelli, and differs only in having a more distinct midrib.

A single leaflet from the Damuda series of India ${ }^{4}$ also shows a close resemblance to the Wealden form; Feistmantel compares it to Sugenopteris rhoifolia, Presl. It is exceedingly difficult to arrive at any satisfactory results as to the limitation of the specific forms of Sagenopteris.

I have ventured to include under the Wealden species the Japanese fragments described by Yokoyama, as there are no apparent differences which suggest specific distinction.

A new species has been recorded from Bornholm under the name S. Nathorsti, Barth.; there is a resemblance worthy of note between Bartholni's fig. 9, pl. v. ${ }^{5}$ and the lowest, broadly-lobed leaflet on the left-hand edge of Dunker's fig. 4, pl. ix.

1 Gymn. böhm. Kreid. pl ii. figs, 1-5.

2 Fl. foss. Aret, vol. vi. pl. xliv. figs. 9-10.

3 Palæontographica, vol. xxvi. 1878, p. 210, pl. xliv. fig. 194.

4 Feistmantel, Foss. Fl. Gond. vol. iii. 1881, p. 114, pl. xliia. fig. 2.

- Bot. Tid. Bot. For. Kjörenharn, 1892. 


\section{2272. PI. IX. Fig. 4.}

Five leaflets are shown in this specimen, but the middle one of the upper three projects bejond the others, and its median line lies somewhat across those of the four palmately-placed segments. There is a distinct indication of the upper end of the leaf-stalk. In some of the leaflets the renation is feebly indicated, but in all of them there is an obvious median groove which becomes more distinct towards the point of attachment.

This apparent midrib is not nearly so distinct in V. 2353, Pl. IX. Fig. 5, and, indeed, were the latter the only available specimen, one would describe the leaflets as without a median vein. The midrib seems to be best represented in those specimens where there is some carbonaceous material on the surface; it appears as a median depression widening towards the base. Cf. Sagenopteris rhoifolia, Presl, var. elongata, Braun., and S. rhoifolia, Presl, var. pusilla, Braun., as represented by Schenk in his "Foss. Flor. Grenz.," pl. xii. Ecclesbourne.

Rufford Coll.

V. 2353. PI. IX. Fig. 5.

In this leaflet the venation is particularly clear; there is no distinct indication of a midrib. Cf. Velenorský, loc. cit. pl. ii. figs, 1-5; also Zigno, Flor. foss. Oolit. vol. i. pl. xxi. fig. $1 b$. Ecclesbourne. Rufford Coll.

V. 2300. Ecclesbourne. Rufford Coll.

V. 2353a. Large leaflets. $C f$. Schenk, ${ }^{1}$ pl. xxxi. fig. 5, and Dunker, ${ }^{2}$ pl. ix. fig. 5 .

V. 2353b. These leaflets agree in shape and in the form of the venation with V. 2353 (PI. IX. Fig. 5); there is a more distinct indication here of a median depression, owing, probably, to the fact that carbonaceous matter is present in this specimen.

V. 2353c. Two leaflets; in the smaller spathulate one very good venation.

V. 2353d. A small leaflet like the two lowest in Fig. 4, Pl. IX. (V. 2272). Ecclesbourne.

Rufford Coll.

2 Wealdenbildung. 
V. 2381. A triangular apical portion of a pointed leaflet. The apex seems to vary considerably in form; it may be either pointed or distinctly obtuse. Ecclesbourne.

Rufford Coll.

? V. 2735. Here are two small leaflets which should possibly be included in this species; on the same specimen is a piece of ? stem structure, with which one of the leaflets is in close contiguity, suggesting a pinnule attached to a rachis. There is, however, no clear evidence of such attachment, and I prefer to regard the juxtaposition as one of the many misleading accidents of fossilization. Midrib more distinct than in most specimens of S. Mantelli. Ecelesbourne.

Rufford Coll.

\section{Genus MICRODICTYON, Saporta.}

[Pal. Franç. 1873, Plantes Jurassiques, vol. i. p. 306.]

This genus was founded by Saporta for the inclusion of certain Jurassic ferns which did not conform in all points to the existing genera Phlebopteris and Thaumatopteris, with which they closely corresponded in general habit. The chief characteristics of the genus are the reticulately disposed lateral veins between the stouter lateral branches, which are given off at right angles to the midrib, also the occurrence of a single row of sori on each side of the midrib. From Phlebopteris Saporta's genus is distinguished by the network of fine veins in the large areolie between the stronger lateral veins, and from Thaumatopteris by the more regularlyplaced and fewer sori. The genus is referred to the tribe Polypodiece.

"Frons pinnata vel saltem frondis segmenta pinnatipartita, pinnis linearibus elongatis; nervi e costa primaria pinnularum orti sub angulo aperto emissi, dein arcuatim conjuncti, arcolas secus nervum medium seriatas efformantes, intus reticulum sorosque rotundos puncto medio solitarie affixos includentes, extus venulas pluries furcato-divisas inter seque varie anastomosatas marginem usque integerrimum emittentes." 1

1 Saporta, Pal. Franç. vol. i. p. 306. 


\section{Microdictyon Dunkeri (Schenk).}

1870. Pecopteris decipiens, Trautschold, Nouv. Mém. Soc. Nat. Moscou, vol. iii. p. 29, pl. xix. fig. 5 .

1871. Laccopteris Dunkeri, Schenk, Palieontographica, xix. p. 219, pl. xxix. figs. 3-5.

1874. Laccopteris Dunkeri, Schimper, Trait. pal. vég. vol. iii. p. 506.

1875. Phlebopteris Dunteri $\left\{\begin{array}{l}\text { Schenk, Palmontographica, xxiii. p. } 161 . \\ \text { Pl. xxvii. fig. } 10 .\end{array}\right.$

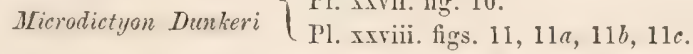

1878. Laccopteris Dunkeri, Hosius and ron der Marck, Palæontographica, xxvi. p. 208, xliv. fig. 192 and 193.

1888. Laccopteris Dunkeri, Velenovsky, Abh. k. böhm. Ges. Wiss. p. 12, pl, ii. figs. $3-7$.

Type. Small pieces of leares showing fertile segments. Originals in the Collections of Berlin and Göttingen.

Schenk defines the species as: "folia . . . . ? segmenta pinnatifida, laciniæ e basi latiore lineares sinu lato rotundato remotæ integræe patentissimæ obtusæ basi $5-6 \mathrm{~mm}$. lato, sori biseriales rotundi, sporangia receptaculo centrali affixa, nervi primarii validi, secundarii angulo acuto egredientes dichotomi, ramuli repetitodichotomi." 1

In a later description of the same species Schenk expands this definition, and we may adopt his amplified diagnosis as affording an accurate description, so far as the imperfect material allows ${ }^{2}$ :-

Leaf-segments deeply pinnatifid, the lobes entire, at right angles to the rachis, linear, obtuse, approximate; midrib strong, secondary veins giren off at a right angle, and forming large meshes which are occupied by a reticulum of smaller reins.

Sori circular, in two rows, without indusia; sporangia eight to ten, vertical incomplete annulus; spores tetrahedral.

The figure of Pecopteris decipiens, Traut., represents a small piece of a leaf-segment with the long straight divisions characteristic of Microdictyon Dunkeri (Schenk). Some of these show traces of the sori. There are no indications of any characters which would justify the retention of Trautschold's species. The rolume of the Nour. Mém. Soc. Nat. Moscou in which Trautschold's paper is published has the date 1876 , but the paper wrapper of a reprint in my

1 Palæontographica, vol. xix. p. 219.

2 Ibid. vol. xxiii. p. 161. 
possession bears the date 1870 , the title page being dated 1871 ; according to the reprint, therefore, we ought to regard Trautschold's species as having priority over Schenk's. Considering the better material and much more complete diagnosis giren by Schenk, I propose to retain his name, in spite of the possible priority of the Russian species.

Schenk, in his first notice of Microdictyon Dunkeri, compares it to Laccopteris elegans, Presl, of Rhrtic age ; in his second paper it is transferred to Saporta's genus, and much new information is added with regard to the fructification. He considers that the fragments are most probably part of a palmately-divided leaf, and agrees with Saporta that Mlicrodictyon comes nearest to certain species of the recent genus Polypodium. ${ }^{1}$

The smaller form from Portugal, named by Heer Laccopteris pulchella ${ }^{2}$ is admitted by the author of the species to bear a close resemblance to L. Dunkeri, but it is separated on account of the difference in size of the ultimate segments, and for some other reasons, the force of which is not very clear. It is not improbable that we might be right in including Heer's species in the list of synonyms, but, considering the imperfections of the trpe specimen of L. pulchella, it is better, perhaps, to retain this additional specific name.

From the Cretaceous plant beds of Bohemia Velenorský describes some larger specimens than have been accessible to earlier writers; they resemble in all points the smaller pieces figured by Schenk. The affinity of the plant is discussed, and the two genera Gleichenia and $C y a t h e a^{3}$ are chosen as the most likely living ferns with which the fossil form must be compared; this comparison is founded on the character of the sori, but Velenorsky's specimens showed no trace of the individual sporangia. He does not mention Schenk's figures and descriptions of well-preserved fertile segments, although the volume in which the Bohemian ferns are described bears the date 1888 , twelve years later than the publication of Schenk's memoir.

In Andrae's account" of the plants from the "Liassic" beds of Steierdorf there are several figures of Andriania baruthina, Fr. Braun, which are exactly similar in habit to Microdictyon

1 Palæontographica, vol. xriii. p. 162.

2 Sece. Trab. Geol. Portugal, 1881, p. 16, pl. xv. fig. 7.

3 Abh. k. böhm. Ges. Wiss, 1888, p. 13.

4 Abh. k.-k. geol. Reichs, rol. ii. Abth. iii. No. 4, p. 36, pl. vii. figs. 1-3. 
Dunkeri (Schenk), hut the renation, as shown in an enlarged pinnule, readily distinguishes this genus from the Microdictyon type. The specimen represented in fig. 1, pl. vii. of Andrae shows the basal ends of six pinnæ attached to the summit of a short rachis, suggesting a close connection, as regards habit, with Ilatonidium. Schenk's figures of Laccopteris Münsteri clearly demonstrate the form of frond characteristic of this class of ferns.

The figures of Carolopteris aquensis, Deb. and Ett., show a type of venation which appears to conform exactly to that of Microdictyon, and the habit is equally similar. Possibly C.aquensis is identical with $\boldsymbol{M}$. Dunkeri; it is certainly rery similar, and without doubt should be removed to Saporta's genus. The second species, C. asplenioides, shows a different venation.

This genus is thus defined by Debey and Ettingshausen ${ }^{1}$ :-

"Frons pinnata (v. bi- . pluries-pinnata). Venæ ramosissimæ, ad costas medianas in areolas polygonas confluentes, marginem versus simplices $r$. furcatæ. Sori ad costam medianam biseriales, magni, orbiculares, globoso-depressi, areolis majoribus, venis reticulatis circumscriptis tectisque insidentes, indusiati, apice orbiculatim dehiscent."

This definition is very similar to Saporta's diagnosis of Microdictyon.

Specimen without Registered Number. Rachis $5.5 \mathrm{~cm}$. long. Ultimate segments show no details of renation; they are alternate, linear and of uniform breadth. On each side of the midrib occur distinct round projections, the regularly-placed sori characteristic of Microdictyon. In coarse quartzose sandstone. Cf. Schenk, Palæontographica, vol. xxiii. pl. xxvii. fig. 10, and pl. xxviii. fig. 11 .

V. 719. No details shown. Sori indicated by depressions in the rock surface. Heathfield.

Purchased.

V. 2214. Probably the same species, but venation hardly visible. Ecclesbourne.

Rufford Coll.

V. 2199 and V. 2298. Fragmenta. Ecclesbourne. Rufford Coll. 52942 $a$. Fragment. Ecclesbourne.

Presented by J. F. H. Peyton, Esq.

1 Denkschr. k. Ak. Wiss. math.-nat. Cl. 1859, vol. xvii. p. 206, pl. iii. 


\section{Genus DICTYOPHYLLUIM, Lindley and Hutton.}

[Fossil Flora, vol. ii. 1833-35, pl. cir. p. 65.]

This generic name was proposed by Lindley and Hutton for a plant originally described by Phillips from the Upper Sandstone and Shale of the Yorkshire Oolite; these authors describe the type specimen, Dictyophyllum rugosum, as a "pinnatifid leaf belonging to some exogenous plant." The older name, Phyllites, having been "taken as the receptacle of all sorts of leares," the new one, Dictyophyllum, is proposed for "doubtful Dicotyledonous leares of common reticulated structure." " Subsequent writers have retained the proposed name, although the discovery of sori on leaves with distinct Dictyophyllum characters has necessitated an entirely new definition of the genus.

The few fragments in the Wealden Collection add nothing to our knowledge of this fern, for which we are chiefly indebted to Schenk; we may, therefore, adopt his definition of the genus ${ }^{2}$ :-

"Folia sterilia et fertilia conformia pedato-pinnata, laciniæ pinnatifidæ. Nervi primarii radiantes, secundarii angulo recto egredientes excurrentes apice in rete soluti, tertiarii angulo recto egredientes maculas inæqualiter hexagonales formantes pluriseriales, costales majores, reliquæ minores, omnes appendicibus anastomosantibus in maculas parvas partiti. Sori per totam paginam folii inferiorem sparsi, rotundi, sporangia pauca annulo multiarticulato instructa, sporæ tetraëdricæ globosæ."

Schimper, ${ }^{3}$ Saporta, ${ }^{4}$ and others include this genus with other closely allied forms in the family Dictyopteridea.

Saporta, in the first volume of his "Plantes Jurassiques," discusses the points of difference between Dictyophyllum, Thaumatopteris, and Clathropteris; these differences depend chiefly on the form of the frond segments and the details of renation. In dealing with small pieces of a frond it is not always easy to decide which genus should be chosen. Clathropteris is, in most cases, readily distinguished by the rectangular nature of the renation, but in a

I Foss. Flor. vol. ii. p. 66.

2 Fl. foss. Grenz. Keup. Lias, p. 75.

3 Trait. pal, vég. vol. i. p. 617.

- Pal. Franç. vol. i. p. 325. 
fragment of Clathropteris Jiüsteriana, Schenk, enlarged by Schenk from the lower portion of a large frond, the venation becomes rery similar to the Dictyophyllum type.

In Nathorst's description of the genus ${ }^{1}$ attention is drawn to the extreme variability of the species, and the consequent difficulty of determining specific and variety limits.

Schenk, in Zittel's "Handbuch der Palæontologie," includes Göppert's genus Thaumatopteris under the generic term Dictyophyllum. Bartholni, ${ }^{3}$ in a recent contribution to the fossil flora of Bornholm, has referred certain specimens to Hausmannia, Dunk., which I am inclined to regard as Dictyophyllum fronds. This author considers that Dunker's genus should be retained for certain forms of reticulately reined leaves; his figures of leaf fragments sufficiently demonstrate the great rariation in the form of the lamina of such leares. Bartholni's figures of Hausmannia Forchiammeri, Barth., ${ }^{4}$ agree closely with those of H. dichotoma as given by Dunker ${ }^{5}$ and Schenk ${ }^{6}$; in the description of the Bornholm fossils no reference is made to this close resemblance to Schenk's North German specimens. So far as it is possible to base any definite opinion on such small specimens as those in the British Museum Collection, it is rery probable that Hansmannia Forchicmmeri, Barth., and Dictyophyllum Roemeri, Schenk, may be the same plant. The nature of Dunker's genus, Hausmannia, ${ }^{7}$ is far from clear; in the "Wealdenbildung" the type specimen of this genus is figured, but unfortunately there is no detailed description or drawing of the renation. In habit the plant may be compared to Dictyophyllum acutilobum, ${ }^{8}$ Schenk, from which it is distinguished by the longer and narrower segments. Schenk makes use of this doubtful ginus for some small fragments found in the North German Wealden rocks, ${ }^{9}$ but his figures are by no means con-

1 Foss. Fl. Schwedens, p. 13.

2 Tol. i. p. 138.

3 Bot. Tids. Bot. For. Kjövenharn, vol, xviii. Heft i. 1892, p. 26.

4 Loc. cit. pl. xi. figs. 4-6; pl. xii. figs. 1-3.

5 Wealdenbildung, pl. v. fig. 1.

6 Palæontographica, vol. xix. pl. xxix. figs. 8 and 9 ; pl. xxxi. fig. 3.

7 Wealdenbildung, p. 12.

8 Fl. foss. Grenz. Keup. Lias, pl. xx.

${ }^{9}$ Palrontographica, rol.xix. p. 223, pl. xxix. figs. 8 and 9. 
clusive as regards the claim of Dunker's generic title to be retained. I expect that the discovery of more perfect examples of what Dunker designated Hausmannia may lead to the conclusion that this genus represents a form of Dictyophyllum. A comparison of Schenk's figures of IIausmannia dichotoma, Dunk., and Nathorst's of Dictyophyllum Nilssoni, Brong., ${ }^{1}$ var. intermedium, in his "Flora of Sweden," is very suggestive of the generic identity of the two species.

\section{Dictyophyllum Roemeri, Schenk.}

1871. Dictyophyllum Roemeri, Schenk, Palæontographica, rol. xix. p. 224, pl. xxxi. fig. 3.

1892. ? Hausmannia Forchhammeri, Bartholni, Bot. Tids. Bot. For. Kjörenhavn, vol. xviii. Heft i. p. 26, pl. xi. figs. 4 and $4 a$.

Type. Small sterile portion of a frond. In the University of Würzburg Collection.

Schenk defines this species as follows:-

"Folia... ? laciniæ margine crenate, crenæ integræ, nerri primarii validi, secundarii angulo recto egredientes, rami et ramuli in rete areas irregulariter polygonas formantes conjuncti." In the fragments from the Sussex Wealden the sori are fairly clearly shown.

Habit of the complete frond unknown; the lamina traversed by strong palmately-disposed reins which probably constitute the central axes of the leaf segments.

The secondary reins form a reticulate structure, and in the larger meshes there are smaller reticulate branches; the sori scattered on the lower surface of the leaf; in some of these the sporangia appear to hare a fairly regular arrangement in groups of four or more round a common centre.

Schenk was the first to record this genus of the Dictyopteridece from Wealden rocks; the present species repeats such characters as are more distinctly shown in the much more perfect and larger fronds found in Rhætic and Jurassic strata. So far as the nature of the species is indicated by the few specimens from German and English beds, it appears to agree with Dictyophyllum

1 Pl. iv. fig. 8. 
acutilobrom, ${ }^{1}$ Schenk, in its venation and the arrangement of the sori. A similar regular disposition of sporangia is shown in Heer's Lower Cretaceous species from Greenland, D. Dicksoni, ${ }^{2} \mathrm{Hr}$.

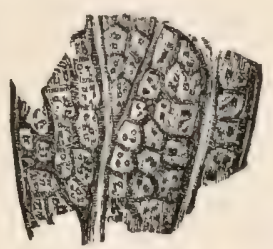

Fig. 16 (V. 2177b). Dictyophyllum Roemeri. Twice natural size.

V. 2177b. Fig. 16.

A small piece of a frond showing portions of three chief veins and, between them, a reticulum of smaller veins. In the meshes of the finer veins there occur small depressions which probably represent sporangia; here and there these appear to have a fairly regular arrangement. Cf. Dictyophyllum Diclisoni, Heer, Fl. foss. Aret. vol. iii. pl. iii. figs. 9 and $9 b, 9 c$ and $9 d$.

In this specimen the finer reticulation is not nearly so apparent as in Schenk's figure, but, in the absence of more satisfactory evidence, I prefer to adopt his specific name, although possibly more perfect material mas show that the English specimens belong: to a separate species. $C f$. also some of the figures of Hausmannia Forchinammeri, Barth., e.g.pl. xi. figs. 4 and $4 a .^{3}$ Ecclesbourne.

Rufford Coll.

V. 2177. A similar fragment to V. 2177b. Traces of sporangial depressions in some of the meshes.

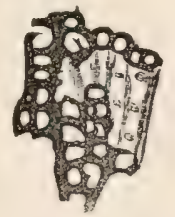

FIG. 17 (V. 2177a). Dictyophyllum Roemeri. Twice natural size.

V. 2177 a. Fig. 17.

Small piece of leaf showing the venation very clearly, as a carbonaceous reticulum. Ecclesbourne. Rufford Coll.

${ }^{1}$ Fl. foss. Grenz. Keup. Lias, pl. xx.

2 Flor. foss. Arct. vol, iii. pl, iii. fig. 9.

s Bartholni, loc. cit. 
V. 2353. Small piece with carbonaceous substance preserred; shows an unevenly-lobed margin. In the venation areolæ occur oval or roundish projections, probably sori. Cf. Schenk's figure of Hausmannia dichotoma, Dunk., also Nathorst's enlarged drawing of Dictyopliyllum Nilssoni, Brong., var. intermedium. ${ }^{1}$ Ecclesbourne.

Rufford Coll.

V. 2815. On one of these specimens is a broad rein from which secondary branches are given off at right angles, and the spaces between are traversed by a network of finer reins. Length of fragment $3.5 \mathrm{~cm}$. ; intervals between the large secondary branches $2 \mathrm{~mm}$. Cf. Hausmannia dichotoma, ${ }^{2}$ Dunker, and Schenk's figure of Dictyophyllum Roemeri, ${ }^{3}$ Schenk. Ecclesbourne. Rufford Coll.

\section{Genus PHYLLOPTERIS, Brongniart.}

[Tableau, 1849, p. 22.]

Brongniart proposed this new genus for certain forms of leares previously referred to Glossopteris and Teniopteris, but which differ from these two genera in the character of their renation. The leaflets included in this genus are considered by Brongniart to belong to pinnate or digitate fronds, more or less lanceolate or linear in shape, with well-marked midrib, and very oblique dichotomously branched veins which do not anastomose to form a reticulum. Glossopteris Phillipsii, Brong., is one of the plants included under Phyllopteris; it is pointed out that Phillips' figure ${ }^{4}$ incorrectly represents the renation as reticulate, also that the plant described and figured by Lindley and Hutton as Glossopteris Phillipsii ${ }^{5}$ is a true Sagenopteris.

Zigno ${ }^{6}$ and Saporta ${ }^{7}$ adopt Brongniart's genus, and the latter

1 Foss. Fl. Schwedens, pl, iv. fig. 8.

2 Wealdenbildung, pl. v. fig. 1.

3 Palæontographica, vol. xix. pl. xxri. fig. 3.

4 Geol. Yorks. 1875, pl, viii. fig. 8.

5 Foss. Flor. vol. i. pl. Ixiii.

6 Flor. foss. Oolit. vol. i. p. 166.

7 Pal. Franç. vol. i. p. 448. 
notes the absence of anastomosing renation as a departure from the Glossopteris leaf, and the oblique course of the secondary reins as a means of distinguishing it from Taniopteris. Saporta's diagnosis differs but little from the earlier description by Brongniart :-

"Frondes rel pinnæ frondium plus minusve lanceolatæ, margine integerrimæ, nervo medio sursum attenuato instructæ; nervis secundariis costa media egredientibus, oblique decurrentibus, curratis, pluries furcato-ramosis nec inter se anastomosatis."

\section{Phyllopteris acutifolia, sp. nov.}

Type. Imperfect leaflets. In the British Museum. Pl. IX. Fig. 6. Leaflets linear- or orate-lanceolate, tapering at the lower end into a short stalk; midrib very distinct in the lower half, but gradually becoming less conspicuous towards the apical portion; lateral veins given off obliquely, and frequently dichotomizing as they curre towards the entire margin of the leaflet.

In the best specimen of this species shown in Pl. IX. Fig. 6, we have an imperfect example of a single leaflet, which in shape agrees fairly closely with Phyllopteris Phillipsii, Brong., from the Middle Sandstone and shale of East Yorkshire. Phillips described this Yorkshire fossil as having anastomosing reins, but, as alrearly noted, Brongniart does not admit such anastomosis and places the specimens in a genus characterized by the absence of reticulate veins. ${ }^{1}$

Nathorst has recorded certain leaflets from Sweden which may be compared, as regards shape and venation, with the present species, e.g. Thinnfeldia rhomboidalis, Ett., ? Sagenopteris undulata, Nath., as represented in pl. xix. fig. 2 of the "Floran vid Bjuf" 2 and in pl. ii. fig. 3 of the "Floran vid Höganäs." 3 This latter species should be compared with S. angustifolia, Zig. Nathorst's* fig. 2, pl. xix. and Zigno's figs. in pl. xx. Flor. foss. Oolit. are

1 See remarks on Glossopteris Phillipsii by Bunbury, Quart. Journ. Geol. Soc. rol. vii. 1851, p. 184.

2 Srer. Geol. Undersökn. 4to. 1878.

3 Ibid. 1878.

4 Ibid. 1886. 
almost identical. A similar form of leaflet has been described by Dr. H. Woodward ${ }^{1}$ from Mount Adams in South Australia, but the original specimen of the figure which he gives is an imperfectly preserved impression on sandstone, and shows no venation except an indication of a midrib; the clearly cut and numerous lateral lines of the woodcut are evidently the engrarer's rein-like shading. Compare also the fragments referred by Newberry to the genus Chiropteris from the Kootanie beds of Montana. ${ }^{2}$

From such specimens as occur in the National Collection it is impossible to arrive at any satisfactory conclusion as to the real nature of the species. The name assigned to it is rather for purposes of convenient reference than intended to conrey the idea of a well-defined specific type.

V. 2816. PI. IX. Fig. 6.

A single leaflet with an apparently truncated apex, due no doubt to tearing. Veins fairly distinct as black curring lines on the brown impression of the lamina. No signs of reticulation noticed. Length $3 \mathrm{~cm}$., somewhat ovate-lanceolate in form. On the same piece of rock is a fragment of what appears to be the short stalk of a leaflet. This specimen comes very near to Chiropteris spatulata, Newb., ${ }^{3}$ from the Kootanie group of MLontana. Ecclesbourne.

Rufford Coll.

V. 2344. Probably the same species, in spite of certain differences in size and shape. The venation is of the same Phyllopteris type; in this specimen the apical part is preserred and shows the lanceolate termination of the leaflet. $C f$. Nathorst, pl. xix. fig. 2, Sagenopteris undulata, Nath., Floran vid Bjuf, Häft iii. 1886. Ecclesbourne.

Rufford Coll.

1 Geol. Mag. dec. iii. rol. ii. 1885, p. 289.

2 Amer. Journ, vol, xli. 1891, pp. 198-199.

3 Ibid. pl. xiv. figs, 1 and 2. 


\section{Genus NATHORSTIA, gen. nor.}

I propose to institute a new provisional genus of ferns for the reception of certain specimens from the English Wealden, which do not conform to the definitions of any known fossil genera; and, as some slight testimony to the palæobotanical labours of Dr. Nathorst, I have ventured to name the plants after him.

It will be seen that the specimens included under this genus are imperfectly preserved frond fragments, and of such a kind that it is impossible to arrive at any very satisfactory conclusion as to their real nature.

Two of the pieces are shown in Pl. VII. Fig. 5 and Pl. IX. Fig. 2; these at first sight suggest portions of distinct species, and at first I regarded them as such.

On more careful examination, however, and after comparison with other specimens, the differences become less pronounced and seem to be rather apparent than real.

In the absence of venation and fructification it is useless to attempt a formal diagnosis of the genus; the characters will be most conveniently indicated in the definition of the single species.

Nathorstia valdensis, gen. et sp. nov.

1871. P Pecopteris Geinilzii, Schenk (in part), Palæontographica, rol. xix. p. 215 , pl. xxix. figs. 2 and $2 \alpha$.

Type. Portions of sterile fronds. British Museum. Pl. VII. Fig. 5.; Pl. IX. Figs. 2 and $2 a$.

Frond bipinnate (?), of slender habit, rachis thin but well marked; pinnæ alternate or subopposite, long and of uniform breadth; the small pinnules attached by the whole of the base, margin entire or very slightly lobed, subdeltoid in shape, apex obtuse; some of the pinnules show faint traces of a millrib, but no lateral veins. Fructification unknown.

The specimen figured by Schenk from the neighbourhood of Hannover as Pecopteris Geinitzii, Dunk., can hardly be referred to that species as figured by Dunker. ${ }^{1}$ On the whole it seems

1 Wealdenbildung, pl. viii. fig. 3. 
probable that Schenk's specimen may be identical with the Sussex examples referred to Nathorstia. It not infrequently happens that the same specific and generic names have been used for Palæozoic and Mesozoic ferns, which have no resemblance to one another; and this confusion no doubt arises from the choice of terms for new species from one geological horizon, without sufficiently considering the names already in use for plants of a different age. An instance of this is afforded by Pecopteris Geinitzii, Dunk.; this name was instituted by Dunker' in 1846 for some specimens of Wealden fern fronds from Northern Germany; in 18.49 Gutbier $^{2}$ makes use of the same name, apparently without knowledge of its previous existence, for some Permian specimens from Saxony. Gutbier's species is retained in Sterzel's recent Monograph on "Die Flora des Rothliegenden im plauenschen Grunde bei Dresden," ${ }^{3}$ but, in view of the priority of Dunker's application of the specific name, some new term should be substituted in the case of Gutbicr's Permian plant. Schimper ${ }^{*}$ includes Gutbier's species under Pecopteris (Cyath.) pinnatifidis (Gutb.), Gein. Some of the pinnules in the pinnæe figured by Schenk appear to show venation, but there is not sufficient evidence in favour of the identity of his specimen with those from the English Wealden to warrant our acceptance of the venation characters as characteristic of Nathorstia valdensis. If specimens are found which are clearly of the same species as those represented in Pl. VII. Fig. 5 and PI. IX. Fig. 2, and show distinct venation of a type characteristic of some existing provisional genus, then the name Nathorstia must be abandoned.

There is a eertain resemblance between the present species and Alethopteris cycadina, Schenk, as figured in pl. xxvi. fig. 6, Palæontographica, rol. xxiii; but the agreement is rery slight, and the earlier figure of the same species by Schenk ${ }^{5}$ represents an entirely different plant to Nathorstia valdensis.

2. Wealdenbildung, p. 6.

2 Die Verstein. Roth. Sachsen. 1849, p. 16, pl. ii. fig. 10; pl. ix. figs. 1-3; pl. xi. figs. 5-6.

3 Abh. math.-phys. Cl. k. Sachs. Ges. Wiss. vol. xix. 1893.

4 Trait. pal. vég. vol. i. p. 507.

5 Palæontographica, vol. xix. pl. xxxi. fig. 2. 
V. 23\%6. P1. IX. Figs. 2 and $2 a$.

The specimen suggests either a delicate and graceful tspe of frond or large pinna, or a young condition of a more robust form. No venation is seen, except a slight trace of a midrib in some of the pinnules, $e g$. Fig. $2 a$. Some of the smaller specimens referred to Cladophlebis Dunkeri (Schenk) have a certain resemblance to the upper pinnæ of this species, but the likeness is probably only superficial. The single pinna at * in Fig. 2, Pl. IX. agrees very closely with the pinnæ of Pl. VII. Fig. 5. Ecclesbourne.

Rufford Coll.

\section{2809. Pl. VII. Fig. 5.}

This specimen, $4 \mathrm{~cm}$. in length, differs from V. $23 \% 6$ (Pl. IX. Fig. 2) chiefly in the closer arrangement and stiffer habit of the pinnæ, and in the smaller size of the pinnules. The lowest pinna on the right-hand side of Fig. 5 agrees with those on the left side of the rachis and close to the apex of Pl. IX. Fig. 2. The matrix is different in the two figured specimens, and this fact alone is often sufficient to account for apparent differences in form.

Sereral of the pinnules hare lobed margins like those of Pl. IX. Fig. $2 a$, and here and there a midrib is indicated.

I was at first inclined to refer this fragment to Göppert's genus Gleichenites, ${ }^{1}$ which includes sereral species from Mesozoic plantbearing beds; but the small and incomplete nature of the material would hardly justify the choice of such a generic term in the absence of any definite evidence of a Gleichenia habit or fructification.

Cf. Gleichenia micromera, Heer, ${ }^{2}$ also Pecopteris (Gleichenites) gleichenoides, O. and M., ${ }^{3}$ Trautschold's figures of what he calls Asplenites Klinensis, ${ }^{4}$ and Gleichenia multinervosa, ${ }^{5}$ Vel. Ecclesbourne.

Rufford Coll.

V. 2173 and $\nabla .2219$. Fragments of apical pinnæ: $c f$. Pl. IX. Fig. 2 (V. 2376), and the tips of the pinnæ of V. 2809, Pl. VII. Fig. 5. Ecclesbourne.

Rufford Coll.

1 Foss. Farrnkrt. 1836, p. 181.

2 Flor. foss. Arct. vol. iii. pl. x.

3 Pal. Ind. pt. i. 1863, vol. i. 1880, pl. xxv.

4 Nouv. Mém. Soc. Nat. Moscou, vol. xiii. 1876, pl. xx. figs. 2 and 4.

5 Abh. k, böhm. Ges. Wiss. vii. Folg. vol. ii. 1888, pl. iii. figs. 1 and 2. 
V. 2299. Small fragment of pinna. Ecclesbourne. Rufford Coll.

V. 2345 and V. 2345a. Small piece of rachis with a few pinnæ; somewhat intermediate in form between Pl. IX. Fig. 2 and Pl. VII. Fig. 5. Ecclesbourne.

Rufford Coll.

V. 2375. A single pinna, $3 \cdot 6 \mathrm{~cm}$. long, of uniform breadth; pinnules show faint traces of venation which may possibly be of the Cladophlebis type; there is the same wavy or slightly-lobed margin as in Pl. VII. Fig. 5 (V. 2809). Ecclesbourne.

Rufford Coll.

\section{Genus TEMPSKYA, Corda.}

[Flor. Vorwelt, 1845, p. 81.]

Corda proposed this term for four specimens of fossil ferns discorered by Tempsky.

He included the genus in the family Phthoropterides, and defined it as follows:-

"Truncus .... Rhachis rotundata, plicata rel alata, cortice crassiuscula, fasciculis vasorum ternatis, majori clauso rel lunulato et supra incurvo, minoribus oppositis lunulatis. Radices minutæ numerosissimæ ; fasciculo vasorum centrali unico."

The older name Endogenites, used by Sprengel ${ }^{1}$ and Brongniart 2 in 1828, was chosen by Stokes and Webb ${ }^{3}$ for Mantell's specimens, which have since been referred to Corda's genus, as expressive of their opinion that the fossils were pieces of some Monocotyledonous stem. Mr. Starkie Gardner ${ }^{4}$ in alluding to certain examples of "Endogenites" in the British Museum, to which Mantell probably referred in his remarks on Monocotyledonous stems in the English Wealden, speaks of them as "of course Cycarleous." If he refers to the common form of Endogenites erosa, there can be no question of Cycadean affinity ; the structure is undoubtedly that of a fern. It would be difficult to give any satisfactory definition of the genus Tempsliya; and secing that such specimens as are

1 Commentat. Psarolithus. p. 21.

2 Prodrome, p. 136.

3 Trans. Geol. Soc. ser. ii. vol. i. p. 423.

4 Brit. Assoc. Report, 1886, p. 3 (reprint). 
usually included under that name are only incomplete pieces of fern stems, any attempted diagnosis would be of little ralue. Solms-Laubach ${ }^{1}$ speaks of certain forms of Rachiopteris occurring in the "Tempstiya condition"; and this probably means that they are imbedded in a felted mass of adrentitious roots. As will be shown in the sequel, certain species previously referred to this genus have been proved by the examination of more perfect material to be referable to other and more precisely defined genera. It will be well for the present to retain Corda's term, if we regard it as implying a particular manner of preservation rather than any well-defined generic characters. Used in this prorisional sense, Tempskya includes such specimens of tree-ferns as consist in the main of felted masses of adrentitious roots, with occasional petioles associated with them, and which are without any distinct vascular cylinder.

Velenorský has made some important additions to our knowledge of these Tempskya forms, which will be referred to under T. Schimperi, Cord.

I am indebted to Prof. Stenzel, ${ }^{2}$ of Breslau, for certain important suggestions as to the nature of the genus Tempskya. He points out that this term is occasionally used in the case of specimens which consist simply of roots without any trace of stems; he mentions the receipt of such a "Tempsiya" from the late Dr. Stur, and compares the structure of the roots to that characteristic of Protopteris punctata or P. microrhiza. This form of Tempstiya, as Stenzel adds, does not conform to the original description by Corda, in which reference is made to petioles associated with numerous roots.

In referring to Corda's opinion that Tempsiya probably represents a portion of a tree-fern stem above the actual stem apex, ${ }^{3}$ Stenzel justly points to the great masses of roots in different species of this genus as a fatal objection to such a view. Stenzel adds that Corda's specimens must have been pieces from the lower part of a stem; but, judging by the great thickness of the rootmass on one side of the stem of T. pulchra and T. Schimperi as figured by Corda, ${ }^{4}$ there must have been a considerable length of

1 Fossil Botany, p. 159.

2 Letter, Dec. 1893.

3 Flor. Vorwelt, p. 81.

4 Ibid. pl. lviii. fig. 1 ; pl. lix. fig. 1. 
stem abore, and the lower petioles would have been long disorganized, as in the lower parts of living tree-fern stems. Possibly, writes Stenzel, Corda's petioles may belong to thin and creeping fern stems, and the roots might possibly be referred to the same creeping axes; but, he adds, such an explanation is hardly probable. Lastly the possibility is suggested that some of the petioles may have belonged to rhizomes creeping amongst the rootmass of a Protopteris stem, as in the case of Zygopteris scandens between the roots of Psaronius. ${ }^{1}$

\section{Tempskya Schimperi, Corda.}

1824. Endogenites erosa, Stokes and Webb, Trans. Geol. Soc. ser. ii. vol. i. p. 423 , pl. xlvi. figs. 1 and 2 ; pl. xlvii. fig. 5 .

1828. Endogenites erosa, Martin, Geol, Mem. Sussex, p. 41.

1833. Findogenites erosa, Mantell, Geol. S.E. England, p. 236, pl. i. figs. 4,5 and 7.

1836. Endogenites erosa, Fitton, Trans. Geol. Soc. ser. ii. vol. iv. p. 172, pl. xix. and $x x$.

1845. Protopteris erosa, Unger, Syn. plant. foss. p. 107.

1845. Tempskya Schimperi, Corda, Flor. Vorwelt, p. 83, pl. lix. figs. 1-2.

1846. Endogenites erosa, Dunker, Wealdenbildung, p. 17, pl. iii. fig. 1.

1846. Sedgwickia yuccoides, Dunker, ibid. p. 84.

1847. Endogenites erosa, Mantell, Geol. Excurs. I. Wight, p. 288.

1848. Endogenites erosa, Bronn, Index pal. nomencl, vol. i. p. 461. Sedgwickia yuecoides, Bronn, ibid. vol. ii. p: 1132.

1849. ? Protopteris erosa, Brongniart, Tableau, p. 107.

1849. Protopteris erosa, Gutbier, Verstein. Roth. Sachsen. p. 17.

1850. ? Porosus marginatus, Cotta, Dendrolithen, p. 41 , pl. viii. figs. 4 and 5 .

1850. Tempshya Schimperi, Unger, Gen. spec. plant. foss. p. 201.

1851. Tempstiya Schimperi, Brom and Roemer, Leth. geog. Th. ir. p. 46, pl. xxviii. fig. 8.

1852. Tempslya Schimperi, Ettingshausen, Abh. k.-k. geol. Reichs. vol. i. Abth. iii. No. 2, p. 19.

1854. Endogenites erosa, Morris, Brit. foss. p. 8.

1866. Tempskya Schimperi, Renger, Ziva, p. 45.

1869. Tempskya Schimperi, Schimper, Trait. pal. vég. vol. i. p. 698.

1871. Tempskya Schimperi, Schenk, Palæontographica, rol. xix. p. 259, pl. xlii. fig. 4 ; pl. xliii.

1878. Tempskya Schimperi, Dixon, Geol. Sussex, p. 282.

18s8. Tempskya Sehimperi, Velenorský, Abh. k. bühm. Ges. Wiss. rii. Folgg. vol. ii. p. 23.

1 Die Gattung Tubicaulis, Bib. bot. Hacnlein und Chlmorm, Heft xii. 18s9, p. 31 . 
Corda ${ }^{\mathrm{I}}$ has defined the species as follows:-

"Rhachi tenui; cortice tenui fuscescente; fasciculo rasorum majori lunulato, æquali, utrinque rotundato; minoribus oppositis, recurvis."

We may substitute the following diagnosis as probably more in accordance with the real nature of the species:-

Masses of numerous branched adventitious roots, and a few small ? petioles forming masses, occasionally several feet in length, and in large specimens about one foot in diameter; the transverse section of the mass is often elliptical in shape, no doubt as the result of pressure; the ends of the specimens frequently taper to a pointed termination, and the external surface may be covered over with a lajer of coaly substance representing carbonized tissue. The roots are of the diarc type, and the petiole structures are characterized by a horseshoe-shaped raseular band. (The central vaseular axis possibly of the Protopteris form).

Among the fossils collected by Mantell from the Wealden rocks of Tilgate Forest, Messrs. Stokes and $\mathrm{Webb}^{2}$ described certain specimens which usually showed an attenuation towards each end, and at times an encrusting shell of carbonaceous matter; to these was assigned the name Endogenites erosa. The appearance of transrerse sections was considered to indicate a Monocotyledonous structure, and hence the generic term Endogenites; the specific name erosa haring reference to the eroded appearance of the surface.

The same fossil was alluded to by Mantell ${ }^{3}$ in 1822 , but without any definite name.

In Martin's work, cited in the synonyniy, there is a footnote stating the occurrence of a silicified specimen near Mulsey.

Mantell reproduces Stokes and Webb's figures, and quotes the opinion of Brongniart that these peculiar Wealden fossils have some resemblance to fern stems. In Fitton's important Memoir 4 we find several figures of specimens of the same fossil from the neighbourhood of Hastings, and with a much more complete description than that previously given by Stokes and Webb. Special attention is drawn to the frequent occurrence of an in-

1 Flor. Vorwelt, p. 83.

2 Trans. Geol. Soc. ser. ii. rol. i. p. 423.

3 Fossils S. Downs, p. 22.

4 Trans. Geol. Soc. ser. ii. vol. iv. p. 17, pls. xix. and $x$. 
resting coat of carbonaccous matter of $\frac{1}{10}$ to $\frac{1}{12}$ inch in thickness, such, e.g., as is represented in a woodcut on page 173 of Fitton's paper. The largest specimen is described as haring a length of 9 feet. My attention has been drawn by Mr. Carruthers to this coaly covering in certain specimens of Tempsiya Schimperi, which he has himself examined in situ in the Isle of Wight; he is of opinion that the coal may be looked upon as the carbonized remains of some peripheral or external tissues, the more internal portions haring been more or less perfectly preserved by mineralization. No doubt we may regard the coal as the carbonized remnants of some external tissues, but there hardly seems any adequate reason for concluding that the tissues, thus reduced to a condition of coal or lignite, were originally of a different nature to those underlying structures which have been partially preserved in the process of fossilization. Corda ${ }^{1}$ figures and describes four species of Tempsliya, but it is by no means easy, from an inspection of his figures, to grasp the points of difference on which the specific characters were founded. He considers T. Schimperi to consist simply of a mass of roots and petioles imperfectly preserved. Dunker ${ }^{2}$ refers to specimens of the same plant from North Germany as representing the stem of some unknown Monocotyledon.

In a later work Mantell ${ }^{3}$ quotes Robt. Brown's opinion that the structure of Endogenites erosa suggests an approach to the Cycadec.

Cotta's ${ }^{4}$ figure of what he calls Porosus marginatus shows what are no doubt numerous small roots, and apparently a few petiole (?) axes.

The specimen figured by Schenk ${ }^{5}$ was found in the Hastings Sands of Neundorf near Hannover, and is regarded by him as identical with Mantell's specimens from the English Weald. This writer prefers to look upon Tempskya Schimperi as an imperfect specimen of part of a complete stem, and not merely a mass of roots and petioles as described by Corda; he recognizes the fern character of the vascular bundles. Schenk speaks of the numerous small and circular vascular bundles as surrounded by selerenchy-

1 Flor. Vorwelt, pp. 81-83, pls. 1viii. and lix.

2 Wealdenbildung, p. 17.

3 Geol. Excurs. I. Wight, p. 288.

4 Dendrolithen, pl. viii. figs. 4 and 5.

5 lalrentographica, rol. xix. pls. xlii. and sliii. 
matous tissue, and the larger bundles as strongly bent in a horseshoe pattern; and he comes to the conclusion that the affinities of the plant are probably with the Marattiacere. On what grounds this comparison is made is not rery clear. The diare nature of the root vascular bundles is opposed to any Marattiaceous affinity. ${ }^{1}$ A large transverse section is figured in pl. xliii. of Schenk's Monograph; the structure is far from perfect, but it suffices to give confirmation to the statement that the specimen is identical with those from the Wealden rocks of England. The general absence of the vascular bundles in the circular root sections and the appearance of all such tissues as are preserved, exactly correspond to what is usually found in our common English examples.

Carruthers" refers to the absence of all traces of foliage in Tempsiya Schimperi, and expresses the opinion that the species may probably be considered as a portion of some arborescent fern. Another species of this genus, T. cretacea, has been described by Hosius and von Marck from the Lower Senonian of Haltern, ${ }^{3}$ and is compared by them to T. Schimperi. In 1872 Feistmantel $^{*}$ drew attention to the doubtful value of Tempskya as a distinct genus, and pointed to the probability of such forms being found to be simply examples of Protopteris Stembergii, Cord., in a particular state of preservation. He suggests that possibly T. pulchra, Cord., T. macrocaulis, Cord., T. microrhiza, Cord., are merely so many states of fossilization of Protopteris Sternbergii, and ilentical with Palmacites varians, Cord., described by Corda in Reuss" "Versteinerungen der bühmischen Kreideformation" ; ${ }^{5}$ the latter he regards as a mass of silicified air-roots of Protopteris Sternbergii. ${ }^{6}$ Feistmantel makes the important announcement that in some of the Tempskyas which he examined it was possible to detach the outer portions of the specimen from an internal nucleus exhibiting the characteristic markings of $P$. Sternbergii.

Velenorsk $\dot{y}^{7}$ has supplemented Feistmantel's remarks with regard to this problematical fossil by his descriptions of specimens from

1 De Bary, Comp. Anat. p. 364.

2 Dixon, Geol. Sussex, p. 282.

3 Palæontographica, vol. xxvi. p. 192, pl. xxrix. figs. 161-163.

4 Abh. k. böhm. Ges. Wiss. vi, Folg. vol. v. 1872, p. 22.

5 p. 87 , pl. xlvii. fig. 7 .

6 Corda's figures in Reuss' work have a distinct resemblance to Palm structures.

? Abh. k. böhm. Ges. Wiss. vii. Folg. vol. ii. 1888, p. 23. 
the Quadersandstein of Bohemia. He adopts the specific term varians, and includes under this species T. pulchra, Cord., T. macrocaulis, Cord., T. micrortiza, Cord., and T. Schimperi, Cord., also Palmacites varians, Cord, and Fasciculites varians, Ung. Velenorsky's description of the Bohemian fossils agrees to a large extent with the characters of the English specimens of T. Schimperi; the surface shows occasional grooves traversing a felted mass of adrentitious roots; the latter are found to consist of a central vascular axis surrounded by several layers of sclerenchymatous elements. The groove-like depressions are regarded as moulds of larger root axes, which frequently branch and break up into such a general felted mass as occurs on the outside of a Dicksonia antarctica stem. The same author alludes to the apparent absence of a central vascular axis in Tempskya, and goes on to describe a specimen from the Prague Museum which throws fresh light on the structure of the species. He speaks of having examined 100 specimens of the fossil without discovering any trace of a central vascular eylinder. The central axis, as preserved in the Prague specimen, seems to agree in all essential respects with that of Protopteris punetata, ${ }^{1}$ and shows the same leaf-trace figure on the petiole scars.

Reference is made to Feistmantel's description of a specimen in which an outer mass of roots was detached from a central core of P. Sternbergii. Finally, Velenorsky conchudes that the form Tempsliya must be regarded as having reference to such states of fossilization in which only the lower parts of a fern root-stock have been preserved; he speaks of his examination of the root-stock of Dicksonia antarctica as confirmatory of this view.

If this connection of the vaseular axis of the Protopteris type with the Tempsiya root-masses be thoroughly established, we must regard the numerous imperfect specimens of $T$. Schimperi, so abundant in the English beds, as simply aggregations of roots, and probably of some other structures, which in the living plants enclosed a Protopteris form of vascular cylinder.

Whether this conclusion of Velenorský be established or not, it is a striking fact that in the ease of English and North German specimens of Tempstiya no example has been found which shows anything of the nature of a Protopteris vascular axis. In the

1 Abh. k. böhm. Ges. Wriss. vii. Folg. vol, ii. 1888, p. 25. 
specimen of Protopteris Witteana already described, which has its minute structure partially preserred, there is certainly a general resemblance in texture and manner of preservation to Tempsliya Schimperi, and such adventitious roots as occur in the neighbourhood of the Protopteris petiole scars appear to agree with those of Corda's species.

The figure of a transverse section of a small root of Tempsliya giren by Velenorsky' (pl. vi. fig. 6) is rather of the nature of a diagrammatic than a very accurate sketch; it gives a very imperfect idea of the structure of the central rascular axis. $\mathrm{He}$ also figures in the same diagrammatic fashion a section of a Dicksonia antarctica root; here again the xylem is not shown at all clearly. In the better specimens of Tempskya Schimperi which I have examined, and in sections of fresh Dicksonia anturctica roots, there is a very close agreement in structure; in both there is a well-marked diare vascular bundle, and in both a strengthening ring of sclerenchyma, with parenchyma on the outside. In pl. vi. fig. 5 of his paper, Velenorsky figures what he describes as the main axis of a root with a horseshoe vascular bundle; this seems to me much more probably a section of a petiolar structure; the form of the vascular bundle is entirely different to that which we find in the adventitious roots of such ferns as Dicksonia antarctica.

Through the kindness of the Director of the Royal Gardens, Kew, and of the Assistant-Curator, Mr. Watson, I have lately had the opportunity of closely examining some specimens of Dicksonia antaictica. In one case Mrr. Watson had a well-grown stem, trrenty-five years old, taken out of the ground; we found that just below the surface of the soil the basal part of the axis became swollen owing to the greater number of adrentitious roots which clothed the lower part of the stem. The central vascular cylinder was prolonged almost to the bottom of the underground mass of roots, tapering towards its somewhat oblique termination.

We did not find any mass of roots below the surface, which was without a central or excentric vascular axis for a sufficient length to account for even the smaller specimens of Tempskya. In the case of older and larger plants of Dicksonia, Mr. Watson tells me that in such cultivated examples as he has noticed there is usually a large ball-like mass of roots below the surface, but these do not extend for more than a short distance, either vertically downwards, or in an oblique direction, without any rascular 
cylinder. We must remember, however, that under natural conditions of growth the case may be otherwise. Be that as it may, my examination of the lower parts of cultivated Dicksonia antarctica stems does not afford any strong support to Velenorskýs riew.

Could the thick enveloping mass of roots readily become separated from the central vascular axis of a tree-fern stem, and thus account for the occurrence in a fossil state of thick bundles of adventitious roots without the central stem axis? We know how it has frequently happened in the case of Lepidodendra stems from the Coal-Measures that the central rascular axis has been completely separated from the outer cortical tissues, and the latter have thus been compressed together, forming an apparently complete specimen. This separation in Lepidodendron is easily explained $b_{5}$ the two concentric lines of weakness which exist in the meristematic layers, the cambium of the central cylinder, and the meristematic zone in the outer cortex. In Diclisonia and other tree-ferns we have no such zones of delicate cells, along which the tearing apart of tissues might readily take place; on the contrary, we have the central vascular tissue with numerous spirally placed petioles bound together by the plexus of roots, and it is not easy to understand how any separation could be effected during fossilization. In Museum specimens of Diclisonia antaretica stems, I am unable to detect any tendency to a clean separation of the surrounding roots from the central axis.

Again, it does not seem probable that the central axis would be disorganized, and the roots remain as mineralized structures; the thick resistant bands of strengthening tissue which accompany the rascular plates would be far more likely to withstand weathering influences than the smaller root structures.

Velenorsky suggests that the roots of Tempsiyg probably drew up from the soil the mineralizing solutions, which erentually replaced their organic cell-walls. It is perhaps conerivable that the roots on the base of the stem may have taken up calcareous or siliceous solutions, and that the central rascular axis did not offer any such convenient path for their ascent; if this were so the axis would gradually decay, and subsequent compression of the root envelope might close up the vacant space and leave no signs in the mineralized mass of any axial structure. This, howerer, is mere speculation, and probably of little or no value in the solution of this difficult question. 
If we turn to the histological structure of Tempsiyg we find, as a rule, the mineralization of the tissues has been very partial, as indeed the extremely porous texture of most of the specimens sufficiently indicates. Schenk's figure affords a good example of this incomplete preservation. In some specimens in the Botanical Department of the British Museum, to which Mr. Carruthers was kind enough to draw my attention, the structure is unusually well shown. Unfortunately in the case of some of these slicles there scems to be some doubt as to the exact locality from which the specimens were obtained. I am also indebted to Mr. Boodle of the Royal College of Science for the opportunity of examining some very interesting sections of Tempskya in his possession, of which he hopes shortly to publish a full description.

The chief feature in specimens of Tempskya in which the detrils are more perfectly preserved is the large number of root sections of various sizes; the central vascular bundle is occasionally exceedingly distinct, and shows a diarc xylem group, of which the larger tracheids have a scalariform or reticulate pitting. Immediately surrounding the tracheids there is a space left by the disorganization of the phloem; and, external to this, sereral layers of thick-walled elements, followed at the periphery of the root by a thin band of parenchyma which, in some cases, shows a remarkably distinct piliferous layer with long and narrow root hairs. These sections in which the root hairs have been preserved appear to be identical with those figured by Corda in Protopteris Cottai. ${ }^{1}$ Transverse sections of the roots of Dicksonia antaretica agree very closely with these fossil roots; we have the same type again in Protopteris microrhiza and P. confuens, Stenz., as figured by Stenzel. ${ }^{2}$

In addition to these smaller diare root bundles, some of the British Museum slides of Tempskya show larger groups of tracheids of a more or less triangular form which may be sections of larger root axes. There is distinct eridence in the great variation in size of the root sections that we are dealing with a mass of branched root structures.

Associated here and there with these adrentitious roots, some of the examples of Tempskya occasionally show sections of larger

I Flor. Vorwelt, pl. L, figs. 1-5.

2 Nova Acta Ac. Cæs. Leop. -Car. vol. xxvi. 1858, pls. xviii. and xix. 
structures; these often appear in the specimens as oral or round tubular carities, but in some cases show a horseshoe rascular band, to which I have already referred in speaking of Velenorskýs figures. Similar structures are represented in Corda's figures of the petioles of Tempskya pulchra and T. micrortiza. ${ }^{1}$ In two of the MLuseum slides there are oblique sections of sclerenchymatous tissue, in which the carities of the fibres have been filled with some opaque black substance, the fibre walls being represented by clear spaces. 'The result is that each selerenchymatous element has the form of a tapered cast of the carity of the fibre, and radiating from this black spindle-shaped borly occur tiny spoke-like structures, eridently casts of the fibre pits. An identical form of preservation has been described by Stenzel ${ }^{2}$ in his paper on Rhizodendran Oppoliense, Göpp.

The general conclusion of these remarks may be summed up as follows: In Tempstya Schimperi we have masses of branched diare fern roots associated with petiole axes, which occasionally afford eridence of branching; probably some forms of Tempskya and Protopteris are very closely related, if not identical plants; but, so far as English specimens are concerned, there is an absence of any direct proof of such organic connection between the two fossils as Feistmantel and Velenorsky' hare previously suggested.

V. 216. This specimen shows good examples of repeatedly branched structures, possibly roots. Ecclesbourne. Rufford Coll.

V. 1441. Two specimens with this registered number; on one piece there is a fairly thick layer of coal enveloping the semimineralized tissues. Ecclesbourne.

Rufford Coll.

V. 2246. V. 2462. Smaller pieces. Ecclesbourne.

Rufford Coll.

7345. Slightly more than 19 inches long. Tilgate Forest.

Mantell Coll.

7346. Eleren inches broad and $3 \frac{1}{2}$ inches thick. Tilgate Forest. Ilantell Coll.

1 Flor. Vorwelt, pl. Iriii.

2 Jahres-Ber. Schles. Ges. Kultur, Frgänzungsheft, 1886, pl. iii. firs. 27-29. 
7348. Another fairly large specimen, from which a section has been cut. Tilgate Forest. IIantell Coll.

7349. This water-worn specimen shows the usual mass of roots, with hollow casts of the larger branched axes. Tilgate Forest.

Mantell Coll.

8343. A section appears to have been cut from this specimen. A felted mass of roots, with the larger branching structures which are possibly petioles; or, as suggested by Velenorský, they may be thicker root structures. Tilgate Forest.

Mantell Coll.

38923, 38924. Longitudinal sections exhibiting the usual Tempsiya characters. Tilgate Forest.

Mantell Coll.

38939, 38940. Roots and other branched axes. Tilgate Forest. IIantell Coll.

48044. Small polished transrerse section. Tilgate Forest.

Mantell Coll.

52590, 52904, 55126. Specimens of the usual type.

One of the largest specimens in the Museum (without a registered number) gives the following measurements: 1 foot 11 inches long, $7 \frac{1}{2}$ inches broad, and $3 \frac{1}{2}$ inches thick. 



\section{LIST OF WORKS QUOTED.}

THE ABBREVIATIONS USED IN THE TEXT ARE GIVEN IN SQUARE BRACKETS.

Andrae, K. T. Fossile flora Siebenbürgens und des Banates. [Abh. k.-k. geol. Reichs. vol. ii. Abth. iii. No. 4, 1853.]

Auerbach, J. Notiz uiber einige Pflanzen-Versteinerungen auș einem Sandsteine des Moskovischen Gouvernements. [Bull. Soc. Imp. Nat. Mosc. vol. xvii. pt. i. 1844, p. 145.]

Auerbach, $J$. and Frears, $H$. Notices sur quelques passages de l'ouvrage de MII. Murchison, E. de Verneuil et le Conte A. de Keyserling. [Bull. Soc. Imp. Nat. Mosc. vol. xix. pt. i. 1846, p. 486.] Baker, J. G. (1) The Handbook of the Fern allies. [Fern allies.] Baker, J. G. (2) A Summary of the new Ferns which have been discovered or described since 1874. [Annals Bot. vol. v. 1890-91, p. 181.]

Bartholni, C. T. Nogle i den bornholmske Juraformation forekommende Plante forsteninger. [Bot. Tid.Bot. For. Fjövenhavn, vol. xviii. Heft i. 1892, p. 12.]

Bary, A. de. Comparative Anatomy of Phanerogams and Ferns. Oxford, 1884. [Comp. Anat.]

Berendt, - . See Göppert.

Bischoff, G. W. Die Chareen und Equiseteen. Nürnberg, 1828.

Bleicher, - - See Fliche.

Bogle, J. H. Wealden Strata of East Sussex. [Trans. Nat. Hist. Soc. Eastbourne, May 20, 1881.]

Bower, F. O. Is the Eusporangiate or the Leptosporangiate the more primitive type in the Ferns? [Annals Bot. vol. v. 1891, p. 109.]

Brauns, D. Der Sandstein bei Seinstedt unweit des Fallsteins und die in ihm Vorkommenden Pflanzenreste. [Palcontographica, vol. ix. 1862-64.]

Bristow, H. W. The Geology of the Isle of Wight, edit. ii. Revised by C. Reid and A. Strahan. [Geol. I. Wight.] 
Brongniart, A. (1) Sur la classification et la distribution des végétaux fossiles en général. [Mém. Mus. Hist. Nat. Paris, vol. viii. 1822, p. 233.]

Brongniart, A. (2) Prodrome d'une histoire des végétaux fossiles. Paris, 1828. [Prodrome.]

Brongniart, A. (3) Histoire des végétaux fossiles. Paris, 1828. [Hist. vég. foss.]

Brongniart, A. (4) Tableau des genres de végétaux fossiles. (Extrait du dictionnaire d'histuire naturelle.) Paris, 1849. [Tableau.]

Bronn, H. G. Index palæontologicus, Nomenclator. Stuttgart, 1848. [Index pal. nomencl.]

Bronn, H. G. and Roemer, F. Lethra geognostica, vol. ii. edit. iii. Stuttgart, 1851-52. [Leth. Geog.]

Buckman, J. On some Fossil Plants from the Lower Lias. [Quart. Joum. Geol. Soc. vol. vi. 1850, p. 413.]

Bunbury, C. J. F. On some Fossil Plants from the Jurassic Strata of the Yorkshire coast. [Quart. Journ. Geol. Soc. vol. vii. 1851, p. 179.]

Carruthers, W. (1) On Caulopteris punctata, Göpp., a tree-fern from the Upper Greensand of Shaftesbury in Dorsetshire. [Geol. Mag. vol, ii. 1865, p. 484.]

Carruthers, W. (2) On some Fossil Coniferous Fruits. [Geol. Mag. vol. iii. 1866 , p. 534.]

Carruthers, W. (3) On Gymnospermous Fruits from the Secondary Rocks of Britain. [Journ. Bot. vol. v. 1867, p. 1.]

Carruthers, W. (4) On some Cycadean Fruits from the Secondary Rocks of Britain. [Geol. Mlag. vol. vi. 1869, p. 101.]

Carruthers, W. (5) On two undescribed Coniferous Fruits from the Secondary Rocks of Britain. [Geol. Mlag. vol. viii. 1871, p. 540.]

Coemans, $E$. Description de la flore fossile du premier étage du terrain crétacé du Hainaut. [Mém. Ac. R. Belg. vol, xxxvi. 1867.]

Congrès géologique international. See Jukes-Browne and Topley.

Corda, A.J. (1) Beiträge zur Flora der Vorwelt. Prag, 1845. [Flor. Vorwelt.]

Corda, A. J. (2) See Reuss.

Cormack, B. G. On a Cambial development in Equisetum. [Annals Bot. vol. vii. 1893, p. 63.]

Cotta, B. (1) [N. Jahrb. 1835, p. 326.]

Cotta, B. (2) Ueber Lepidodendron punctata von Grossenheim. [N. Jahrb. 1836, p. 30.]

Cotta, B. (3) Die Dendrolithen. Leipzig, 1850. [Dendrolithen.]

Credner, H. Elemente der Geologie, edit. vi. Leipzig, 1887. 
Dauson, J. W. (1) On an undescribed Fern from the Lower CoalMeasures of Nova Scotia. [Quart. Journ. Geol. Soc. vol. xvii. 1861, p. 5.]

Dawson, J. W. (2) On the Condition of the Deposition of Coal, more especially as illustrated by the Coal formation of Nova Scotia and New Brunswick [Quart. Journ. Geol. Soc. vol. xxii. 1866, p. 153.]

Dawson, J. W. (3) Palæontological notes. [Canad. Nat. vol. x. 1883, p. 1.]

Dauson, J. W. (4) The Cretaceous Floras of Canada. [Nature, vol. xxxiii. 1885, p. 32.]

Dartson, J. W. (5) On the Mesozoic Floras of the Rocky Mountain region of Canada. [Trans. $R$. Soc. Canada, vol. iii. 1886.]

Dauson, J. W. (6) Fossil floras and climate. [Nature, vol. xlvii. 1893, p. 556.]

Debey, M. H. and Von Ettingshausen, C. (1) Die Urweltlichen Thallophyten des Kreidegebirges von Aachen und Mrstricht. [Denkschr. k. Ak. Wiss. Wien, vol. xvi. 1859, p. 131.]

Debey, Mr. H. and Fon Ettingshausen, C. (2) Die Urweltlichen Acrobryen des Kreidegebirges von Aachen und Mæstricht. [Denkschr. k. Ak. Wiss. Wien, vol. xvii. 1859, p. 185.]

De Candolle. Flore Française, vol. iii. Paris, $\mathbf{1 8 1 5}$.

Dixon, $F$. Geology of Sussex, edited by T. Rupert Jones (Plants by Carruthers). Brighton, 1878. [Geol. Sussex.]

Dunker, W. (1) Ueber der norddeutschen sogennanten Wälderthon und dessen Versteinerungen. Programme der höheren Gewerbschule in Cassel. 1843. [Progr.]

Dunker, W. (2) Monographie der norddeutschen Wealdenbildung. Braunschweig, 1846. [Wealdenbildung.]

Dupont, $E$. Sur la découverte d'ossements d'Iguanodon, de poissons et de végétaux dans la fosse Sainte-Barbe du Charbonnage de Bernissart. [Bull. Ac. R. Belg. vol. xlvi. sér. ii. 1878, p. 387.] Duval-Jouve, J. Histoire naturelle des Equisetum de France. Paris, 1864. [Hist. nat. Equisetum.]

Eichuald, E. d'. (1) Die Vorweltliche Fauna und Flora des Grünsandes der Umgegend von Moskwa. [Bull. Soc. Imp. Nat. Mosc. vol. $\mathrm{xxxv}$. pt. ii. 1862, p. 355.]

Eichwald, E. d'. (2) Lethæa Rossica, Période Moyenne. Stuttgart, 1868. [Leth. Ross.]

Engelhardt, $H$. Ueber Kreidepflanzen von Niederschöna. [Abh. Isis. Dresden, 1891, p. 79.]

Ettingshausen, C. von. (1) [Jahrb. k.-k. geol. Reichs. Jahrg. ii. No. 2, p. 156.] 
Ettingshausen, C. von. (2) Beiträge zur Flora der Vorwelt. [Haidinger Nat. Abh. vol. iv. Abth. i 1851, p. 65.]

Ettingshausen, C. von. (3) Ueber Palæombremelia, ein neues Fossiles Pflanzengeschlecht. [Abh.k.-k. geol. Reichs. vol. i. Abth. iii. 1852, p. 1.]

Ettingshausen, C. von. (4) Beitrag zur näheren Kenntniss der Flora der Wealden Periode. [Abh k.-k. geol. Reichs. vol, i. Abth, iii. No. 2, 1852, p. 1.]

Ettingshausen, C. von. (5) See Debey.

Ettingshausen, C. von. (6) Die Farrnkrüuter der Jetztwelt. Wien, 1865.

[Farrnkrt. Jetztwelt.]

Ettingshausen, C. von. (7) Die fossile Flora des Mährisch-Schlesischen Dachschiefers, [Sitz. k. Ak. Wiss. Wien. math.nat. Cl. vol. li. Abth. i. 1865.]

Et:ingshausen, C. von. (8) Die Kreideflora von Niederschöna in Sachsen.

Ein Beitrag zur Kenntniss der ältesten DicotyledonenGewächse. [Sitz. k. Ak. Wiss. Wien, math.-nat. Cl. vol. lv. Abth. i. 1867, p. 235.]

Fée, A. L. A. (1) Genera Filicum. Exposition des genres de la famille des Polypodiacées. Paris and Strasburg, 1850-52. [Genera Filicum.]

Fée, A. L. A. (2) Cryptogames vasculares du Brésil. Paris, 1869. [Crypt. vasc. Brésil.]

Feistmantel, O. (1) Ueber Baumfarrenreste der böhmischen Steinkohlen-, Perm- und Kreideformation. [Abh,k, böhm. Ges. Wiss. vi. Folg. vol. v. 1872.]

Feistmantel, O. (2) Fossil Flora of the Gondwana System. Mem. Geol. Surv. India. Vol. i. ser. ii. 1880, pt. ii. (1877), and vol. iii. 1881, pt. i. (1879). [Foss, Fl. Gond.]

Fcistmantel, $O$. (3) Uebersichtliche Darstellung der Geologisch-palæontologischer Verhältnisse Süd-Afrikas. Th. i. [Abh.k. böhm. Ges. Wiss. vii. Folg. vol. iii. 1889.]

Fitton, W. H. Obserrations on some of the Strata between the Chalk and the Oxford Oolite in the South-East of England. [Trans. Geol. Soc. ser. ii. vol. iv. 1836, p. 103.]

Fliche and Bleicher. Étude sur lia flore de l'oolithe inférieure aux environs de Nancy. [Bull. Soc. Sci. Nancy, sér. ii. vol. v. 1881, p. 54.]

Fontaine, II. Af. (1) Contributions to the knowledge of the Older Mesozoic Flora of Virginia. Washington, 1883. [C.S. Geol. Surv. Mon. vi.]

Fintrine, IT. M. (2) The Potomac or Younger Mesnoic Flora. (U.S. Geol. Surv. Mon. xv. Washington, 1889.) [Potomac Flora.] 
Fontaine, W. M. (3) Description of some Fossil Plants from the Great Falls Coal-field of Montana. [Proc. U.S. Nat. Mus. vol. xv. 1892, p. 487.]

Gardner, J. S. (1) On Mesozoic Angiosperms. [Geol. Mlag. vol, iii. 1886, p. 193.]

Gardner, J. S. (2) and other Members of the Committee appointed for the purpose of reporting on the Fossil Plants of the Tertiary and Secondary beds of the United Kingdom. [B.A. Report, 1886, p. 241.]

Geikie, A. Text Book of Geology, edit. iii. London, 1893.

Geinitz, E. Beitrag zur Geologie Mecklenburg. (i.) Geschiebe von Hörsandstein. [Arch. Ver. Freund. Nat. Mecklenb. Jahr. xxrvi. 1882, p. 49.$]$

Geyler, H. T. Ueber fossile Pflanzen aus der Juraformation Japans. [Palceontographica, vol. xxiv. 1877, p. 221.]

Glocker, E. F. von. Ueber die kalkführende Sandstein-formation auf beiden Seiten der Mittleren March, in der Gegend zwischen Kwassitz und Kremsier. [Nova Acta Ac. Coes. Leop.-Car. vol. xix. supp. ii. 1841, p. 309.]

Godfrey, J. H. G. Notes on the Geology of Japan. [Quart. Joum. Geol. Soc. vol. xxxiv. 1878, p. 542.]

Göppert, H.R. (1) Die fossilen Farrnkräuter. (Nova Acta Ac. Caes. Leop.-Car. vol, xvii. supp. 1836.) [Foss. Farrnkrt.]

Göppert, H. R. (2) Die Gattungen der fossilen Pflanzen. Bonn, 1841. [Gatl. foss. Pft. $]$

Göppert, H. R. and Berendt. (3) Die Bernstein und die in ihm befindlichen Pflanzenreste der Vorwelt. Berlin, 1845. [Bernstein.]

Göppert, H. R. (4) See Murchison.

Göppert, H. R. (5) Ueber das Vorkommen von Baumfarn in der fossilen Flora, insbesondere in der Kreidefornation. [ $\mathrm{N}$. Jahrb. 1865, p. 395.]

Gutbier, A. von. Die Versteinerungen des Rothliegenden in Sachsen. Dresden and Leipzig, 1849. [Verstein Roth. Sachsen.]

Haller, A. Histoire Stirpium indigenarium Helvetiæe inchoata. Vol. iii. Bernæ, 1768. [Hist. Stirp. indig. Helvet.]

Harvey, W. H. Phycologia Britannica. London, 1846-51. [Hurvey.] Heer, O. (1) Flora Tertiaria Helvetiæ. Die Tertiäre Flora der Schweiz. Winterthur, 1855. [Fl. Tert. Helvet.]

Heer, O. (2) Beiträge zur Kreide-Flora. ii. Zur Kreide-Flora von Quedlinburg. [Neue Denkschr. Schweiz. Ges, Nat. vol, xxiv. 1871.]

Heer, 0. (3) Flora fossilis Arctica : die fossile Flora der Polarlände. Zürich, 1868-83. [Fl. foss. Arct. $]$ 
Heer, O. (4) Flora fossilis Helvetiæ. Zürich, 1876. [Fl. foss. Helvet.] Heer, 0. (5) Die Urwelt der Schweiz. Edit. ii. Zürich, 1879. [Urwelt.]

Heer, O. (6) Contributions à la flore fossile du Portugal. [Secc. Trab. Geol. Portugal, 1881.]

Helwing. Flora quasimodogenita, sive enumeratio aliquot plantarum indigenarum in Prussia. 1712. [Fl. Plant. indig. Pruss.]

Hooker, J. D. On the vegetation of the Carboniferous period as compared with that of the present. [Mem. Geol. Surv. vol. ii. pt. ii. 1848.]

Hooker, W. J. H. (1) Genera Filicum. London, 1842.

Hooker, W. J. H. (2) Species Filicum. London, 1846-64.

Hooker, W. J. and Baker, J. G. (3) Synopsis Filicum. London, 1868.

Hosius and von der Mfarck. (1) Die Flora der Westfälischen Kreide-

formation. [Palocontographica, vol, xxvi. 1879-80, p. 127.]

Hosius and von der Marck. (2) Weitere Beitrïge zur Kenntuiss der fossilen Pflanzen und Fische aus der Kreide Westfalens. [Palacontographica, vol. xxxi. 1885, p. 227.]

Hutton, W. See Lindley.

Jack, R. L. and Etheridge, R., jun. The Geology and Palæontology of Queensland and New Guinea. Brisbane, 1892.

Joger, G. F. Ueber die Pflanzenversteinerungen welche in den Bausandstein von Stuttgart vorkommen. Stuttgart, 1827. [Pflanzen Verstein. Stuttgart.]

Judd, J. W. On the Punfield Formation. [Quart. Journ. Geol. Soc. vol. xxvii. 1871, p. 222.]

Jukes-Browne, A.J. and Topley, W. Congrès géologique international. Compte rendu de la 4me session, 1888. Report of SubCommittee No. ii. Cretaceous. Londres, 1891. [Cong. Géol. Int. 1888.]

Kayser, E. Textbook of Comparative Geology. Translated and edited by P. Lake. London, 1892. [Comp. Geol.]

Kidston, $R$. On the Occurrence of the Genus Equisetum (E. Hemingwayi, Kidst.) in the Yorkshire Coal-Measures. [Annals, vol. ix. 1892, p. 138.]

Knowlton, F. H. (1) Description of a Problematic Organism from the Devonian at the Falls of the Ohio. [Amer. Journ. ser. iii. vol. xxxvii. 1889, p. 202.]

Knoxlton, F. H. (2) Fossil Wood and Lignite of the Potomac Formation. [Bull. U.S. Geol. Surv. No. 56, 1889.]

hinowlton, F. H. Description of a new Fossil Species of Chara. [Bot. Gazette, vol. xviii. 1892, p. 141.]

Lamarck. [Ann. Mus. Hist. Nat. Paris, vol. v. 1804, p. 356.] Lamplugh, G. W. See Pavlow. 
Lapparent, A. de. Traité de Géologie. Paris, 1885. [Trait. Géol.] Leckenty, J. On the Sandstones and Shales of the Oolites of Scarborough, with descriptions of some new Species of Fossil Plants. [Quart. Journ. Geol. Soc. vol. xx. 1864, p. 74.]

Léman. Note sur la Gyrogonite. [Nouv. Bull. Sci. Paris, vol, iii. ann. 5, No. 58,1812 , p. 101.]

Lesquereux, L. (1) Geological Survey of Illinois. Vol. ii. Palæontology. 1866. [Geol. Surv. Illinois.]

Lesquereux, L. (2) Contributions to the Fossil Flora of the Western Territories. Pt. i. Cretaceous Flora. [Rep. U.S. Geol. Surv. vol. vi. 1874.]

Lesquereux, L. (3) The Flora of the Dakota Group; a posthumous Work. Edited by F. H. Knowiton. [U.S. Geol. Surv. Mon. xvii. 1892.]

Linares, $A . G$. de. Sobre la existencia del Terreno Wealdico en la cuenca del Besaya (Province de Santander). [An. Soc. Españ. Hist. Nat. vol. iii. 1878. p. 87.]

Lindley, J. and Hutton, W. The Fossil Flora of Great Britain. London, 1831-37. [Foss. Flor.]

Linnaxus, K. L. Genera Plantarum. Lugduni Batavorum, 1737. [Gen. Plant.]

Ludwig, $R$. Fossile Pflanzen aus der tertiären Spatheisenstein von Montabauer. [Palceontographica, vol. viii. 1859-61, p. 160.]

Luerssen, C. Die Farnpflanzen oder Gefässbündel-kryptogamen (Pteridophyta). [Rabenhorst's Krypt. Flora, vol. iii. Leipzig, 1889.]

Lyell, $C$. On a recent Formation of Fresh-water Limestone in Forfarshire, etc., and an appendix on the Gyrogonite or Seedvessel of the Chara. [Trans. Geol. Soc. ser. ii. vol. ii. 1826, p. 90.]

Mantell, G. (1) The Fossils of the South Downs, or Illustrations of the Geology of Sussex. London, 1822. [Fossils S. Downs.] Mantell, G. (2) Descriptions of some Fossil Vegetables of the Tilgate Forest in Sussex. [Trans. Geol. Soe. ser. ii. vol, i. 1824, p. 421.] Mantell, G. (3) Illustrations of the Geology of Sussex. London, 1827. [Illust. Geol. Sussex.]

Mantell, G. (4) The Geology of the S.E. of England. London, 1833. [Geol. S.E. England.]

Mfantell, G. (5) A Tabular Arrangement of the Organic Remains of the County of Sussex. [Trans. Geol. Soc. ser. ii. vol. iii. 1835, p. 201.]

Mantell, G. (6) The Wonders of Geology. Edit. iii. London, 1839. Mantell, G. (7) Geological Excursions round the Isle of Wight. London, 1847. [Geol. Excurs. I. Wight.] 
Martin, P. I. A Geological Memoir on a part of Western Sussex. London, 1828. [Geol. Mem. Sussex.]

Martius. Denkschr. k. Baier. bot. Ges. vol. ii. 1822, Abth. i.

Meddelelser om Grönland. Oversight over Grönland's Fossile Flora. Vol. v. Kjöbenhavn, 1883. [Mreddel. Grönland.]

Meek, F. B. Report of the Geological Survey of Ohio. Vol. i. Geology and Palæontology, pt. ii. 1873, p. 219 (note). [Report Geol. Surv. Ohio.]

Migula, W. Die Characeen. Rabenhorst's Kryptogamen Flora von Deutschland, Oesterreich und der Schweiz. Vol. v. Leipzig, 1890. [Rabenhorst's Krypt. Flora.]

Mitde, J. Monographia Equisetorum. [Mon. Equiset. Nova Acta Ac. Coes. Leop.-Car. Vol. xxxii. 1865.]

Morris, J. A Catalogue of British Fossils. Edit. ii. London, 1854. [Brit. Foss.]

Mourlon, M. Géologie de la Belgique. Brussels, 1880-81. [Géol. Belg.]

Murchison, R. I. et Verneuil, E. de, et Keyserling, A. von. The Geology of Russia in Europe and the Ural Mountains. London and Paris, 1845. [Geol. Russia.]

Afurray, G. On a Fossil Alga belonging to the genus Caulerpa from the Oolite. [Phycol. Alem. pt. i. 1892, p. 11.]

Nathorst, A. G. (1) Om Floran i Skånes Kolförande Bildningar

i. Floran vid Bjuf. Häft i. 1878.)

ii. " $\quad$ " Häft ii. 1879. [Flor. Bjuf.]

iii. " " Häft iii. 1886.

iv. Floran vid Höganäs och Helsingborg, 1878. [Flor. Höganäs.]

Sver. Geol. Undersökn, 4to. Stockholm.

Nathorst, A. G. (2) Beitrïge zur fossilen flora Schwedens. Ueber einige rhätische Pflanzen von Pilajö in Schonen. Stuttgart, 1878. [Foss. Fl. Schwedens.]

Nathorst, A. G. (3) Beiträge zur mesozoischen Flora Japans. [Denkschr. k. Ak. Wiss. math.-nat. Cl. vol. Ivii. 1890, p. 43.]

Nettiorst, A. G. (4) Ueber des angebliche Vorkommen von Geschieben des Hörsandsteins in den Norddeutsehen Diluvialablagerungen. [Arch. Ver. Freund. Nat. Mrecklenb. Jahr. xliv. 1890.]

Nexberry, J. S. (1) The Flora of the Great Falls Coal-field, Montana. [Amer. Journ. vol. xli. 1891, 191.]

Nexberry, J. S. (2) The Cretaceous Flora of North America. [Trans. N. York. Ac. Sci. vol. v. 1885-86.]

Oldhctm, T. and Morris, J. Fossil Flora of the Gondwana System. 
Vol. i. ser. ii. 1880, pt. i. Fossil Flora of the Rajmahal series in the Rajmahal Hills. 1863. Mem. Geol, Surv. India. [Foss. Fl. Gond. $]$

Passy, A. Description géologique du département de la Seine-inférieure. Rouen, 1832. [Depart. Seine-inférieure.]

Parlon', A. et Lamplugh, G. W. Argiles de Speeton et leurs équivalents. Moscou, 1892. [Arg. Speeton.]

Peyton, J. E. H. Note on a Wealden Fern, Oleandridium (Teniopteris) Beyrichii, Schenk, new to Britain. [Quart. Journ. Geol. Soc. Proc. 1882, p. 3.]

Phillips, J. (1) On a Fossil Fruit found in the upper part of the Wealden Deposits in Swanage Bay, Isle of Purbeck. [Quart. Journ. Geol. Soc. vol. xv. 1859, p. 46.]

Phillips, J. (2) Illustrations of the Geology of Yorkshire. Pt. i. : The Yorkshire Coast. Edit. iii. Edited by R. Etheridge. London, 1875. [Geol. Yorks.]

Plant, J. Wealden Fossils from Columbia, South America. [Proc. Lit. Phil. Soc. Mfanchester, vol. xvi. 1877, p. 50.]

Potonié, H. (1) Ueber einige Carbon Farne. [Jahrb. k. preuss. Geol. Landesanst, 1889, p. 21.]

Potonié, $H$. (2) Ueber einige Carbon Farne. Th. ii. [Jahrb. $k$. preuss. Geol. Landesanst, 1890, p. ii.]

Potonie, $H$. (3) Ueber einige Carbon Farne. Th. iii. [Jahrb. k. preuss Geol. Landesanst, 1891, p. 1.]

Raciborski, M. Ueber die Osmundaceen und Schizæaceen der Juraformation. [Bot. Jahrb. vol. xiii. 1891, p. 1.]

Renault, B. et Zeiller, R. (1) Sur des Mousses de l'époque houillère [Compt. Rend. vol. c. 1885, p. 660.]

Renault, B. et Zeiller, R. (2) Sur l'attribution des genres Fayolia et Palceoxyris. [Compt. Rend. vol. cvii. 1888, p. 1022.]

Renault, B. et Zeiller, R. (3) Flore fossile du terrain houillier de Commentry. [Fl. foss. houill. Commentry.]

Renault, B. (4) Cours de botanique fossile. Paris, 1881-85. [Coners bot. foss.]

Renger. Předvèké rostlinstvo kridového útvari českého. [Zira, 1866.] Reuss, A. E. Die Versteinerungen der böhmischen Kreideformation. Stuttgart, 1845-46. [Verstein. böhm. Kreid.]

Richthofen, F. von. China. Vol. iv. Pflanzliche Versteinerungen, Schenk. Berlin, 1883.

Roemer, $F . A$. Die Versteinerungen des norddeutschen OolithenGebirges. Ein Nachtrag. Hannover, 1839. [Verstein, Ool. Geb.]

Roemer, Ferd. Geologie von Oberschlesien. Breslau, 1870. [Geol. Oberschles.] 
Rouillier, C. (1) Explication de la coupe géologique des environs de Moscou. [Bull. Soc. Imp. Nat. Mosc. vol. xix. 1846, p. 359.] Rouillier, C. et Vossinsky, - . (2) Études progressives sur la paléontologie des environs de Moscou. [Bull. Soc. Imp. Nat. Mose. vol. $x x$. i. 1847, p. 446.]

Saporta, G. de. (1) Prodrome d'une flore fossile des travertins anciens de Sézanne. [Mém. Soc. Géol. France, sér. ii. vol. viii. 1865, p. 289.]

Saporta, G. de. (2) Plantes Jurassiques. [Pal. Frang. sér. ii. vols. i.-iv. 1873-91.]

Saporta, G. de. (3) Sur les plus auciennes Dicotylées Européennes observées dans le gisement de Cercal, en Portugal. [Compt. Rend. vol. cxiii. 1891, p. 249.]

Saporta, G. de. (4) Revue des travaux de paléontologie végétale parus en France dans le cours des années 1889-92. [Rev. Gen. Bot. vol. v. 1893.]

Schenk, A. (1) Die fossile Flora der Grenzschichten der Keupers und Lias Frankens. Wiesbaden, 1867. [Fl. foss. Grenz. Keup. Lias.]

Schenk, A. (2) Beitrïge zur Flora der Vorwelt. Die Flora der nordwestdeutschen Wealdenformation. [Palcoontographica, vol. xix. 1871, p. 203.]

Schenk, A. (3) Die fossilen Pflanzen der Wernsdorfer Schichten in der Nordkarpathen. [Palcontographica, vol. xix. 1871, p. 1.]

Schenk, A. (4) Zur Flora der nordwestdeutschen Wealdenformation. [Palceontographica, vol. xxiii. 1875-76, p. 157.]

Schenk, A. (5) See Richthofen.

Schenk, A. (6) Die während der Reise des Grafen Bela Széchenyi in China gesammelten fossilen Pflanzen. [Palceontographica, vol. $x x x i .1885$, p. 165.]

Sckenk, A. (7) Fossile Pflanzen aus der Albourskette. [Bibl. bot. Uhlworm und Haenlein, Heft vi. 1887.]

Schenk, A. (8) Die fossilen Pflanzenreste. Breslau, 1888. [Schenk's Handbuch, vol. iv.]

S'chimper, W. P. Traité de paléontologie végétale.

$$
\left.\begin{array}{l}
\text { Vol. i. } 1869 \\
\text { Vol. ii. } 1870-72 \\
\text { Vol. iii. } 1874
\end{array}\right\} \text { [Trait. pal. vég.] }
$$

Schlotheim, E. F. von. Nachträge zur Petrefactenkunde. Gotha, 1822. [Petrefactenkunde.]

Schmalhausen, J. Beiträge zur Jura-flora Russlands. [Yém. Ac. Imp. St. Pétersburg, sér. vii. vol. xxvii. No. 4, 1879.] 
Schulze, E. Ueber die Flora der subhercynischen Kreide. Inaugural Dissertation. Halle, 1888. [Flor, subhercyn. Kreid.]

Solms-Laubach, Graf zu. Fossil Botany. English translation. Oxford, 1891.

Sprengel, A. Commentatio de Psarolithis. Halle, 1828.

Squinabol, $S$. Contribuzioni alla Flora fossile dei Terreni Terziarii della Liguria. Vol. i. Characee, etc. Genove, 1889 ; vol. ii. Alghe, Genove, 1891. [Contrib. Fl. foss. Liguria.]

Staub, M. Dichsonia punctata, Stbg. sp., in der fossilen Flora Ungarns. [Földt. Közl. 1890, p. 227.]

Stenzel, K. G. (1) Ueber Farn Wurzeln aus dem Rothenliegenden. [Nova Acta Ac. Coes. Leop. -Car. vol, xxvi. 1858, p. 225.]

Stenzel, K. G. (2) Rhizodendron Oppoliense, Göpp. [Jahres.-Ber. Schles. Ges. Kultur, 1886.]

Stenzel, G. (3) Die Gattung Tubicaulis Cott.: Bib. bot. Haenlein und Uhlworm, Heft xii. Cassel, 1889.

Stemberg, C. Graf von. Versuch einer geognostisch-botanischen Darstellung der Flora der Vorwelt. Leipzig. [F'lor. Vorwelt.]

Fasc. i. pp. 1-24, pl. i.-xiii. 1820.

, ii. pp. 1-33, pl. xiv.-xxvi. 1821.

" iii. pp. 1-39, pl. xxvii.-xxxix. 1823.

„ iv. pp. 1-42, pl. xl.-lix. and A-E. 1825.

" v. and vi. pp. 1-48, pl, i--xxvi. 1833.

" vii. pp. 1-200, pl. xxvii.-lxviii. pl. A-B. 1838.

, viii. pp. 1-71. 1838.

Sterzel, J. T. Die Flora der Rothliegenden im plauenschen Grunde bei Dresden. [Abh. math.-phys. Cl. k. Sachs. Ges. Wiss. vol. xix. 1893.]

Stiehler, A. W. (1) [Ber. nat. Ver. Harz, 1853-54, p. 14.]

Stiehler, A. W. (2) Ueber fossile Pflanzen aus der Kreideformation von Quedlinburg. [Zeitsch. deutsch. geol. Ges. vol. vi. 1854, p. 659.]

Stiehler, A. W. (3) Beiträge zur Kenntniss der Vorweltlichen Flora des Kreidegebirges im Harze. [Paloentographica, vol. v. $1855-58$, p. 7.]

Stokes and Webb. Descriptions of some Fossil Vegetables of the Tilgate Forest in Sussex. (The authors' names do not appear in the title of this paper.) [Trans. Geol. Soc. ser. ii. vol. i. 1824, p. 421.]

Struckmann, C. (1) Die Wealden-Bildungen der Umgegend von Hannover. Hannover, 1880. [Weald. Hannover.]

Struckmann, C. (2) Die Grenzschichten Zwischen Hilsthon und Wealden bei Barsinghausen am Deister. [Jaltrb. $k$. preuss. Geol. Landesanst. 1889, p. 54.] 
Stur, D. (1) Die Lunzer (Lettenkohlen -) Flora in den "Older Mesozoic beds of the Coal-field at Eastern Virginia." [Verh. k.-k. geol. Reichs. No. 10, 1888, p. i.]

Stur, D. (2) Beiträge zur Kenntniss der Flora der Vorwelt. Vol, ii. Die Carbon-flora der Schatzlarer Schichten. Abth. i. [Abh. k.-k. geol. Reichs. vol. xi, Abth. i, 1885.]

Tate, R. On some Secondary Fossils from South Africa. [Quart. Joum. Geol. Soc. vol. xxiii. 1867, p. 139.]

Tenison-Woods, J. E. On the Fossil Flora of the Coal Deposits of Australia. [Proc. Linn. Soc. N.S. Wales, vol. viii. pt. i. 1883.]

Topley, W. (1) The Geology of the Weald. Mem. Geol. Surv. London, 1875. [Weald.]

Topley, W. (2) See Jukes-Browne, A. J.

Trautschold, T. (1) Recherches géologiques aux environs de MLscou. [Bull. Soc. Imp. Nat. Mosc. vol. xxxi. pt. iv. 1858, p. 546.]

Trautschold, T. (2) Ueber der Kreide-Ablagerungen im Gouvernement Moskau. [Bull. Soc. Imp. Nat. Mosc. vol. xxxiv. pt. iv. 1861, p. 432.]

Trautschold, T. (3) Der Klin'sche Sandstein. Moscou, 1870. [Nouv. Mém. Soc. Nat. Moscou, vol. xiii. 1876, p. 191.]

Ulrich, E. O. Contributions to American Palæontology. [Geol. Mrag. N.S. dec. 3, vol. iii. 1886, p. 374.]

Unger, $F$. (1) Synopsis Plantarum fossilium. Lipsex, 1845. [Syn. plant. foss.]

Unger, $F$. (2) Genera et species plantarum fossilium. Vindobonæ, 1850. [Gen. spec. plant. foss.]

Unger, F. (3) Reise der Oesterreichischen Fregatte Novara um die Erde. Geologischer Theil, vol. i. Abth. ii. p. 1. Wein, 1864. [Reise Fregatte Novara.]

Vaillant. [Hist. Ac. R. Sci. 1719, p. 17. Paris, 1721.]

Velenovskiy, J. (1) Die Gymnospermen der bölmischen Kreideformation. Prag, 1885. [Gym. böhm. Kreid.]

Telenovsky, J. (2) Die Farne der böhmischen Kreideformation. [A $6 h$. k. böhm Ges. Wiss. vii. Folg. vol. ii. 1888.]

IFard, L. F. (1) The Geographical Distribution of Fossil Plants. [U.S. Geol. Surv. Ann. Rep. No. 8, 1887-88.]

Ward, L. F. (2) Evidence of the Fossil Plants as to the age of the Potomac formation. [Am. Journ. Sci. ser. iii. vol. xxxvi. 1888, p. 119.]

Weichsel, -. [Ber. Nat. Ver. Harz, 1853-54, p. 24.]

Nethered, E. On the Occurrence of Calcisphere, Williamson, in the Carboniferous Limestone of Gloucestershire. [Quart. Journ. Geol. Soc. vol. xliv. Proc. 1888, p. 91.] 
White, C. A. Correlation papers. Cretaceous. [Bull. U.S. Geol. Surv. No. 82, 1891.]

Thite, D. A new Tæniopteroid Fern and its allies. [Bull. Geol. Soc. America, vol. iv. 1893, p. 119.]

Williamson, W. $C$. On the organization of the Fossil Plants of the Coal-Measures. Pt. $x$. [Phil. Trans. 1880, p. 493.]

Toodward, $H$. Notes on some Mesozoic Plant Remaius from South Australia. [Geol, Mag. vol. ii. 1885, p. 289.]

Woodward, H. B. The Geology of England and Wales. Edit. ii. London, 1887.

Iokoyama, M. (1) On the Jurassic Plants of Kaga, Hida and Echizen. [Bull.Geol. Soc. Japan, pt. B, vol. i. No. 1, 1886.] .

Yokoyama, M. (2) Jurassic Plants from Kaga, Hida and Echizen. [Journ. Coll. Sci. Japan, vol. iii. 1890.]

Zeiller, R. (1) Bassin houiller de Valennciennes. Paris, 1888.

Zeiller, R. (2) Annuaire Géologique. Vol. viii. 1892-93, p. 893. [Ann. Géol.]

Zeiller, R. (3) See Renault.

Zrgno, A. de. Flora fossilis formationis Oolithicæ. Vol. i. Padova, 1856. [Flor. foss. Oolit.]

Zittel, K. A. Handbuch der Palrontologie. Vol. i. Schimper, W. P. and Schenk, A. Munich and Leipzig, 1890. [Handbuch.] 



\section{INDEX OF GENERA, SPECIES, ETC. :}

\section{MENTIONED IN THE DESCRIPTIVE PART OF THE CATALOGUE.}

\section{[Synonyms are printed in italics.]}

Acrostichopteris, 60, 61 . densifolia, 62 . longipennis, 60,62 . Ruffordi, 61, 62, 84 . Acrostichum, 36, 60, 61 . peltatum, 61 .

Adiantites Mantelli, 130.

Alethopteris, 92. Albertsii, 91, 92, 94.

Browniana, 99, 100. cycadina, 146.

elegans, 63, 64 .

Ettingshausei, 115.

Göpperti, 63.

Huttoni, 98.

recentior, 115, 117.

Reichiana, 99.

Rösserti, 92 .

Whitbyensis, 88, 92, 95.

Algacites, 2, 3.

Alga, 1-8.

Algites, 2-4.

catenelloides, 6, 7 .

Valdensis, 4-8.

Andriania Baruthina, 136.

Aneimidium Klipsteinii, 131. Mantelli, 130.

Aneimites, 75 .

Anemia, 39, 75, 81, 83. adiantifolia, 76-81.

Angiopteridium, 124.

Anomopteris, 115, 117. Ludovice, 115.

Aspidium, 36, 102 Dunkeri, 101, 102.

Asplenites Klinensis, 115, 118, 147. palcopteris, 107, 108, 112. Rösserti, 87, 89, 95, 96.

Asplenium, 36, 80, 88, 89, 93, 95, 108.

argutulum, 96.

Dicksonianum,

fœniculaceum, 80 .

fragrans, $7,8,80$.

Whitbyensis, 96.
Botrychium, 22.

Bryophyta, 15-19.

Calamites arenaceus, minor, 25.

Calcisphæra, 11.

Lemoni, 11.

Carolopteris aquensis, 137. asplenioides, 137.

Carpolithus, 28, 29. cordatus, 27.

Huttoni, 27.

Lindleyanus, 27, 29.

Mantelli, 27, 28.

sertum, 28, 33, 34 .

Catenella, 7, 8 .

Caulerpa, 1, 2, 5. arcuata, 6.

Carruthersii, 2.

Caulerpites, 1, 2.

Caulopteris, 71. punctata, 72.

Chara, 9-12.

Bleicheri, 12.

fœtida, 14.

Jaccardi, 12, 13.

Knowltoni, 12-14.

medicaginula, 14.

Meriani, 14.

Millardi, 12.

Stantoni, 14

Characeæ, 9-14.

Charophyta, 9-14.

Cheilanthites Göpperti, 76.

Mantelli, 41.

Chiropteris, 144. spatulata, 144.

Chondria, 5.

Chondrides, 5. dolichophyllus, 5 .

Chondrites, 1, 5.

Chondrus, $1,4,8$. crispus, 4,7 .

Cladophlebis, 87, 95, 101, 104, 124. acuta, 93, 96 . 
Cladophlebis Albertsii, 91-98, 113.

Browniana, 66, 99, 100.

deuticulata, 93 .

Dunkeri, 99, 100-104, 147, 159.

falcata, 93, 96.

Haiburnensis, 88.

inclinata, 94 .

ligata, 88.

lobifolia, 88 .

longipennis, 89-91.

nebbensis, 116, 119.

Rösserti, 94, 95.

tenuis, 88 .

Whitbyensis, 88, 94-96.

Clathropteris, 138.

Münsteriana, 139.

Confervites fissus, 6, 41 . setaceus, 6 .

Coniferæ, 21.

Cryptogramme, 47, 48. crispa, 51 .

Cyathea, 136.

Cyatheaceæ, 62-75.

Cycadinocarpus cordatus, 27.

Huttoni, 27.

Lindleyanus, 27.

Mantelli, 27.

Cycadites Althausii, 63.

Cyclopteris, 75.

Acadica, 76 .

Mantelli, 130.

Danæites, 123.

Danæopsis, 124.

Davallia, 51. gibberosa, 51 .

Dichymosaurus, 89.

Dicksonia, 36, 47, 56, 69, 71 . antarctica, 69, 74, 154-156. elongata, $40,55,56$. punctata, 72.

Dictyophyllum, 138-140. acutilobum, 139-141.

Dicksoni, 141.

Nilssoni, 140, 142.

Roemeri, 139, 140-142.

Dictyota, 4. rugosum, 138.

\section{Endogenites, 148.} erosa, 148, 150, 151, 152.

Equisetaceæ, 22-35.

Equisetinx, 22-35.

Equisetites, 22-24.

arcticum, 31.

arenaceum, 31.

Burchardti, 27-34.
Equisetites Hemingwayi, 23.

Lusitanicum, 25.

Lyelli, 24-27.

Múunsteri, 26, 31.

Parlatorii, 31.

Phillipsii, 25, 26.

Ushimarense, 29.

Yokoyamæ, 28, 33-35.

Equisetum, 20, 22, 23, 30.

arvense, 30,31 .

maximum, 30.

palustre, 30.

sylvaticum, 30 .

Telmateia, 30 .

tuberosum, 31,

Virginicum, 29.

Fasciculites varians, 154.

Filicites, 104.

punctatus, 72 .

Florideæ, 5.

Fontinalis, 16.

Fucoides, 3.

erectus, 5, 17, 18.

Fucus, 3.

Furcellaria, 5.

Gleichenia, 136, 147.

micromera, 147.

multinervosa, 147.

Nordenskiöldi, 100.

Zippei, 100.

Gleicheniace», 90.

Gleichenites, 147.

Glossopteris, 142, 143.

Phillipsii, 142.

Glyptostrobus gracillimus, 21.

Gymnogramme, 40.

Gymuostomum ferrugineum, 17.

Gyrogonites, 9.

Gyrophyllites Theobaldi, 5 .

\section{Halyserites gracilis, 19.}

Hausmannia, 140.

dichotoma, 140, 142.

Forchhammeri, 139-141.

Helminthostachys, 22.

Hepaticæ, 17-19, 21.

Hymenophyllum Tunbridgense, 117.

Hymenopleris psilotoides, 41, 43.

Hypneæ, 15.

Isoetes, 22. 
Jeanpaulia nervosa, 78.

Jungermannia, 17.

Jungermannites, 17, 21.

Juniperus macilenta, 21.

Klukia, 39, 75.

Laccopteris Dunkeri, 135, 136.

elegans, 136.

Göpperti, 63.

Münsteri, 137.

pulchella, 136.

Lepidodendron, 156.

punctatum, 68, 70 .

Lonchopteris, 113, 114, 117, 119.

Bricii, 119.

Mantelli, 114-119.

recentior, 115, 118.

Virginiensis, 119.

Lycopodites, 21.

Maakii, 15.

uncinatus, 15.

Lycopodium phlegmaria, 20.

Marattiaceæ, 122, 153.

Marattiopsis, 124.

Marchantia, 17, 18. chenopoda, 18. oolithicus, 17.

Marchantites, 18. Zeilleri, 18, 19.

Marsilea, 61, 129, 130.

Matonia, 62, 63. pectinata, 63,65 . sarmentosa, 63 .

Matonidium, 62, 63, 66, 137. Göpperti, 63-67.

Microdictyon, 134, 136, 137. Dunkeri, 65, 135-137.

IIicrolepis Mantelli, 42.

Moellerina, 11.

Mohria, 39.

Musci, 15.

Muscinex, 15-19.

Muscites, 16. cretaceus, 16. falcifolius, 16 . imbricatus, 16. polytrichaceus, 15 .

Sternbergianus, 16.

Najadita, 16.

Nathorstia, 145.

Valdensis, 145-148.

Neuropterides, 87.
Neuropteris, 35, 87, 91, 128. Albertsii, 91-93.

Nilssonia, 122. orientalis, 123.

Nitella, 10.

Nitophyllum, 4. Bonnemaisoni, 4.

Oleandra, 122, 123, 125. neriiformis, 125 .

Oleandridium, 122-124. Beyrichii, 125.

Eurychoron, 129.

Onoclea struthiopteris, 95 .

Onychiopsis, 40, 41, 47, 48, 51 .

capsulifera, 49.

elongata, 41, 47-49, 52, 55-60, 106.

Mantelli, 6, 39, 41-54, 56, 59, $97,108,112,113$.

Onychium, 40, 47, 48, 50, 51, 53 .

Japonicum, 51.

Osmundaceæ, $9 \tilde{.}$

Pachypteris gracilis, 107, 108.

Palmacites varians, 153, 154.

Pecopteris, 3, 35, 87-89, 117.

Althausii, 63, 65 .

Auerbachiana, 115.

Brouniana, 99-102.

caspitosa, 64.

Conybeari, 63,64 .

decipiens, 135.

dentata, 94 .

Dunkeri, 100-103.

exiliforme, 101, 102.

exilis, 39, 75, 101, 102 .

explanata, 63,65 .

Geinitzii, 89, 145-146.

Geyleriana, 101-103, 116, 119, 120.

gleichenoides, 147.

Murchisoniana, 115, 117.

nebbensis, 94.

nigrescens, 118.

obtusifolia, 102.

pachycarpa, 65 .

pinnatifida, 146.

polydactyla, 63,64 .

polymorpha, 100, 101.

Reichiana, 99.

reticulata, 114, 115.

temis, 93.

Ungeri, 100.

Whitbyensis, 87, 89, 91-93.

Zippei, 100. 
Phlebopteris, 134. Duntieri, 135 .

Phyllites, 138.

Phyllopteris, 124. acutifolia, 143, 144. Phillipsii, 143.

Phyllotheca, 20, 27. equisetiformis, 20. Schtschuraroskii, 20.

Physagenia Parlatorii, 31 . Polypodiaceæ, 40-62.

Polypodites Mantelli, 114, 115.

Polypodium, 36, 60, 136.

Polytrichum, 15.

P'orella, 21.

Porosus marginatus, 152.

Protopteris, 68, 69, 73, 150, 151, 154-158.

confluens, 157.

Cottai, 73, 74, 157.

Cotteana, 71, 73 .

Debeyi, 72.

erosa, 150 .

fibrosa, 73.

microrhiza, 149, 157.

punctata, 70, 72, 73, 149, 154 .

Sternbergii, 71-73, 153, 154.

Witteana, 69-75, 155.

Pteridophyta, 22-159.

Pteris, 36, 95, 118. Albertini, 92.

Albertsii, 91, 92, 94.

frigida, 93 .

reticulata, 115.

Pterophyllum filicum, 115. ITurehisonianum, 115.

\section{Rachiopteris, 3, 149.}

Reboulia hemisphrerica, 6.

Restiacex, 29.

Rhipodopteris, 61.

Rhizodendron Oppoliense, 73, 158.

Rhizogonium, 15.

Thodymenia, 4 .

Ruffordia, 75, 76 .

Göpperti, 39, 44, 45, 75-86, 106.

\section{Saccammina Eriana, 11.}

Sagenopteris, 129, 130, 132, 142.

angustifolia, 143,

Mantelli, 130-134.

Nathorsti, 132.

Neocomiensis, 132.

rhoifolia, 131-133.

Stoliczana, 130.

undulata, 143, 144.

Sargassites Partschii, 6.
Schizacex, 75-86.

Scleropteris dissecta, 103.

Pomelii, 110, 120.

Sedgwictia yuccoides, 150.

Sigillaria punctata, 72 .

Speirocarpus Haberfelneri, 119.

Sphærococcides, 5.

Sphrrococcites, 5.

chondriæformis, 6 .

Sphenolepis Kurriana, 42, 44.

Sphenopteris, 3, 35, 36, 47, 51, 75, $88,90,104-113$.

adiantifrons, 76 .

acrodentata, 79, 86 .

antipodum, 48 .

Auerbachi, 77, 79.

Bunburyanus, 110.

Cordai, 56, 109.

Delgadoi, 107, 112.

elongata, 51.

Fittoni, 97, 107-113.

flabellifolium, var. erecta, 91, 94 .

Fontainei, 19, 106.

fragilis, 110 .

Gomesiana, 56, 112.

Göpperti, 39, 45, 55, 56, 60, 75, $76-78,84,86$.

gracilis, 107, 108.

Hartlebeni, 76-78.

Hœninghausii, var. Larischiformis, 111.

Jugleri, 44, 76-78.

longifolia, 76-78.

IIantelli, 39, 41-43, 46, 48, 51, $56,58,108$.

Phillipsii, 76-78, 86.

Pichleri, 109, 112.

plurinervia, 56, 110, 112.

Roemeri, 41, 42, 44 .

Sillimani, 41-44, 54.

Steenstrupi, 79 .

tenera, 41, 44, 108.

Valdensis, 42, 45, 48, 77, 78 .

Tænidium Lusitanicum, 6 .

Tæniopteris, 122-129, 142, 143.

Beyrichii, 123, 125-128.

Dawsoni, 123-129.

Forbesii, 124.

obtusa, 127.

spatulata, 126.

stenoneura, 126.

superba, 127.

tenuinervis, 126.

vittata, 122 .

Zabingiana, 128.

Tempskya, 148-150, 156, 157.

cretacea, 153. 
Tempskya macrocaulis, 153.

microrhiza, 153, 158.

pulchra, 149, 153, 154, 158.

Schimperi, 40, 149, 150-159.

Thallophyta, 1-8.

Thaumatopteris, 134, 138, 139.

Thinnfeldia, 132.

Lesquereuxiana, 132.

rhomboidalis, 143.

variabilis, 130, 132 .

Thyrsopteris, $36,40,45-47,55-57,93$.

alata, 57,58 .

angustifolia, 58 .

brevipennis, 79 .

capsulifera, 47, 59.

crenata, 58.

densifolia, 58 .

elliptica, 58.

elongata, 40, 55 .

heterophylla, 53 .

inæquipinnata, 58, 110 .

insignis, 46.

Kagensis, 79.
Thyrsopteris Meekiana, 57, 58, 60 .

microphylla, 52,58 .

pinnatifida, 58.

rarinervis, $46,55,57$.

Virginica, 57.

Trichomanites Göpperti, 78.

laxum, 42,45 .

spinifolium, 42,45 .

Vittaria, 124.

Walchia, 29.

Weichselia, 113, 114, 117, 119, 121. erratica, 116, 118.

Ludovica, 115, 116, 118.

Mantelli, 113-121

Widdringtonites Reichii, 21.

Zonaria, 4.

Zygopteris scandens, 150 . 



\section{EXPLANATION OF PLATES.}

All the figured specimens are preserved in the British Mruscum, their registered numbers being quoted in square brackets. The figures are drawn natural size, except in one or two cases where the enlargement is statel. With the exception of Pl. I. Figs. 1 and 2, Pl. X. Fig. 3, and Pl. XI., all the specimens are from the Rufford Collection. 
FIG. 1. Algites valdensis, gen, et sp. nov. Carbonaceous impression of thallus. Page 6 .

Algites catenelloides, gen. et sp. nov. The small branched impressions associated with the previous species. P. 7 .

[V. 2857.]

FIG. 2. Algites valdensis, gen. et sp. nov. P. 6.

Algites catenelloides, gen et sp. nov. At a the elliptical form of the cells is shown. P. 7 .

[V. 2857.]

Fig. 3. Marchantites Zeilleri, sp. nov. The branched vegetative body. P. 19.

[V. 2330.]

Fig. 4. Equisetites Lyelli, Mant. Stem showing leaf-sheaths and the base of a lateral branch. P. 25.

[V. 59.]

Fra. 5. Equisetites Burchardti, Dunk. Tubers and root attached to a node. The left-hand tuber shows two teeth at the apex. P. 32 .

[V. 2367.]

Fig. 6. Equisetites Burchardti, Dunk. Three long and slender divisions of a leaf-sheath shown in the left-hand fragment. P. 32.

[V. 2367.]

Fig. 7. Specimen A (Plante incerte sedis). P. 19.

[V. 2370.]

FIG. 8. Specimen B (Plantex incerte sedis). P. 20.

Fig. 9. Small piece of a branch of Fig. 8 enlarged 10 times. [V. 2328.] 


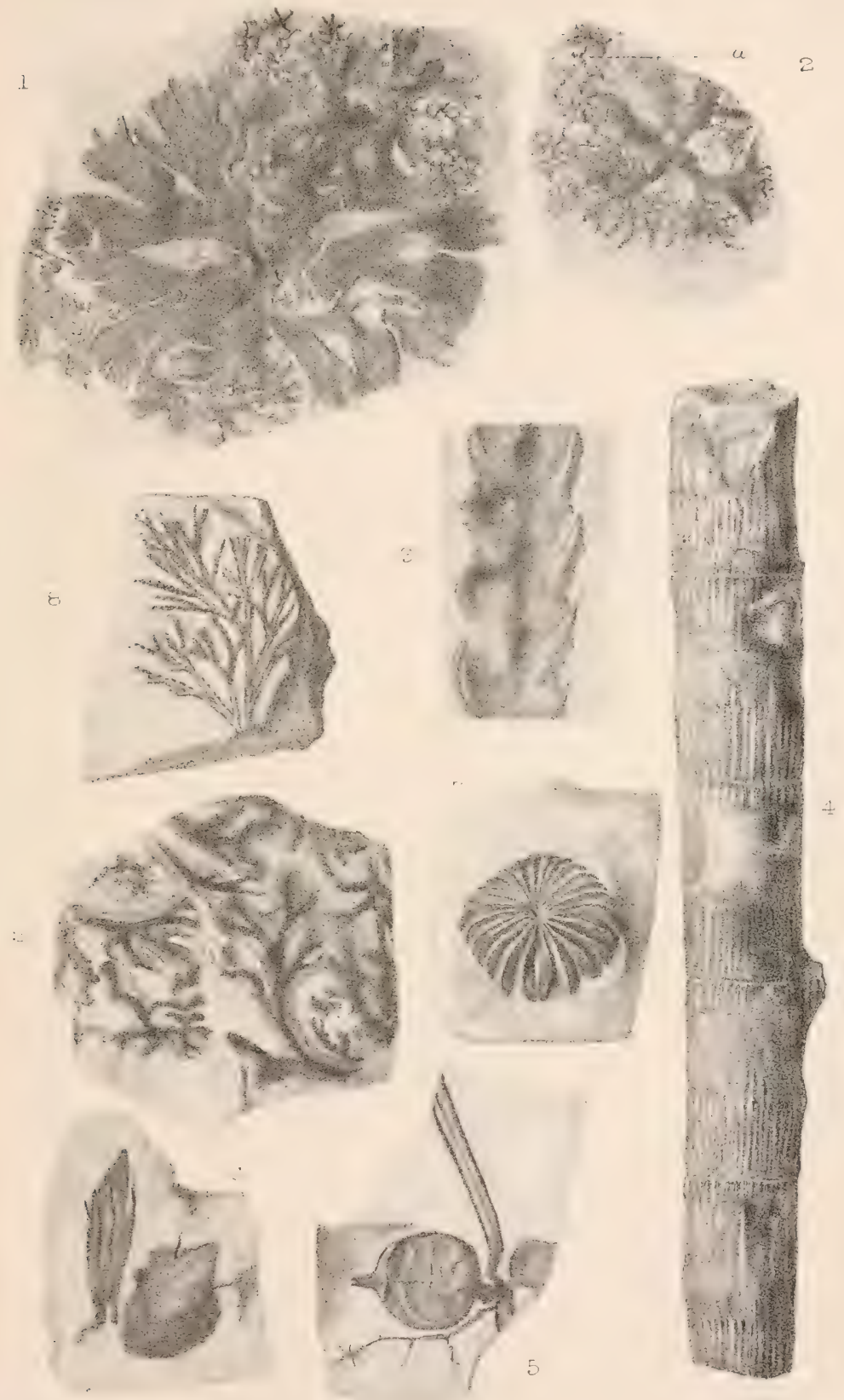

E.C \& G.M.Woodward del.ctlith

Wealden, Algæ, Marchantites, Equisetites, etc. 


PLATE II.

FIG. 1. Onychiopsis Mrantelli (Brong.). Frond showing habit well, but details not very distinct. Page 48. [V. 2168.]

FIG. 2. Onychiopsis elongata (Geyler). Portions of pinne. P. 59.

[V. 2731.] 


\section{₹ $(10)$} $+4=(v)(y)$

HW $=$ NMW

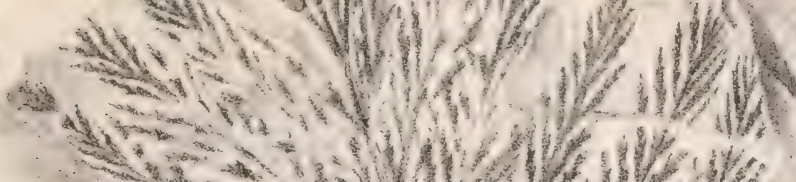
$1+2+1+1$ AN - DWWWW $1-4=-11$

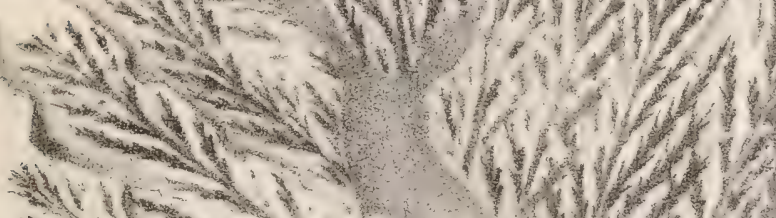
writs $=1, \quad$ y

= $\ldots+\ldots$ WWW

(1) $\frac{\pi}{x}=3$

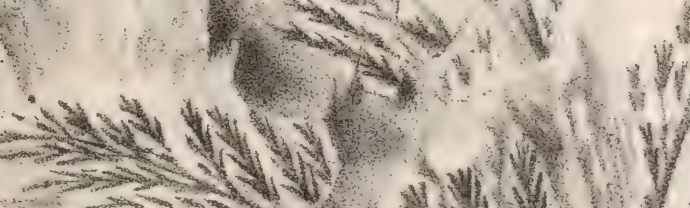
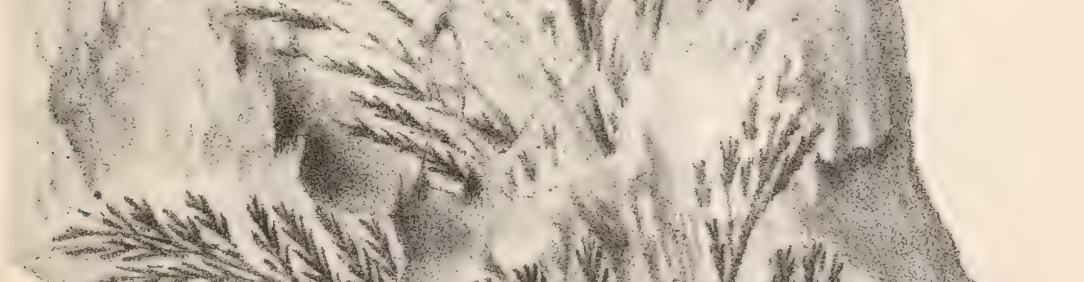

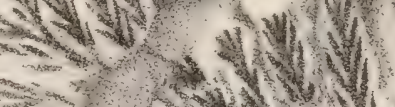
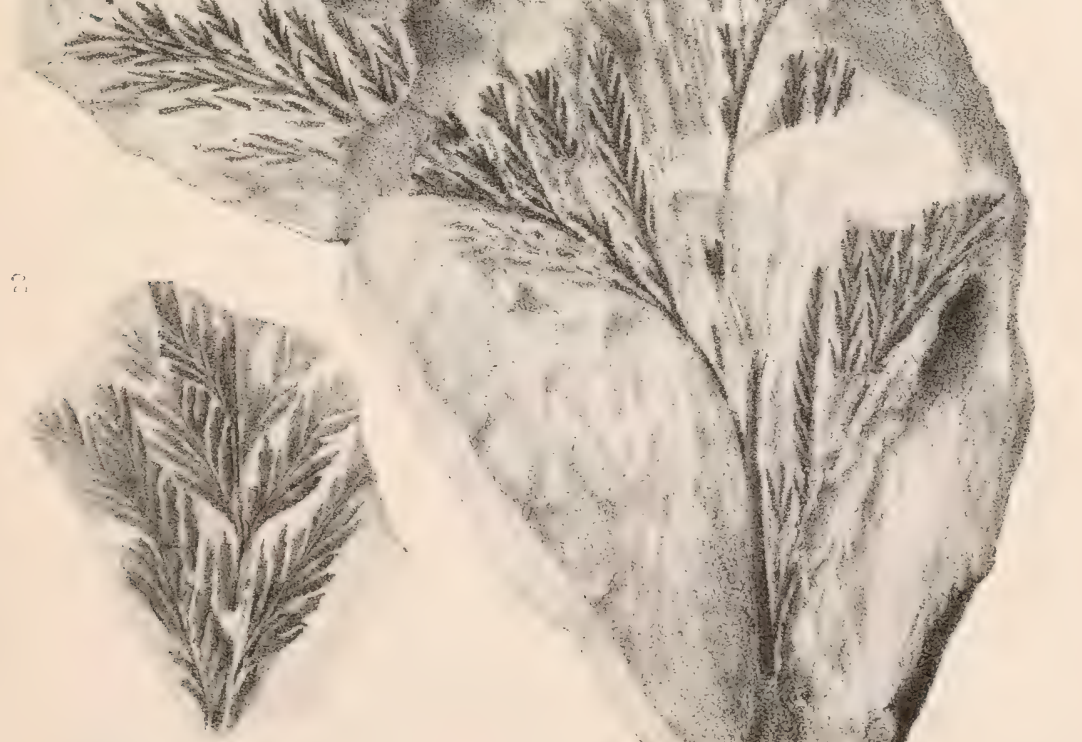


PLA'IE III.

FIG. 1. Onychiopsis Muntelli (Brong.). Smaller form of frond. Page 48. [V. 2151a.]

FIG. 2. Onychiopsis Mantelli (Brong.). Fragments of fertile pinua. P. 49 .

[V. 2151.]

FIG. 3. Onychiopsis Mantelli (Brong.). Terminal portion of a fertile pinna. P. 49.

[V. 2159.]

FIG. 4. Onychiopsis Mantelli (Brong.). Portions of three fertile axes. P. 49.

[V. 1069.]

FIG. 5. Ruffordia Göpperti (Dunk.). Part of a sterile frond. P. 82.

[V. 2731.]

FIG. 6. Ruffordia Güpperti (Dunk.). Fragment showing a sterile upper portion, and two basal fertile pinnæ. P. 83.

[V. 2295.] 

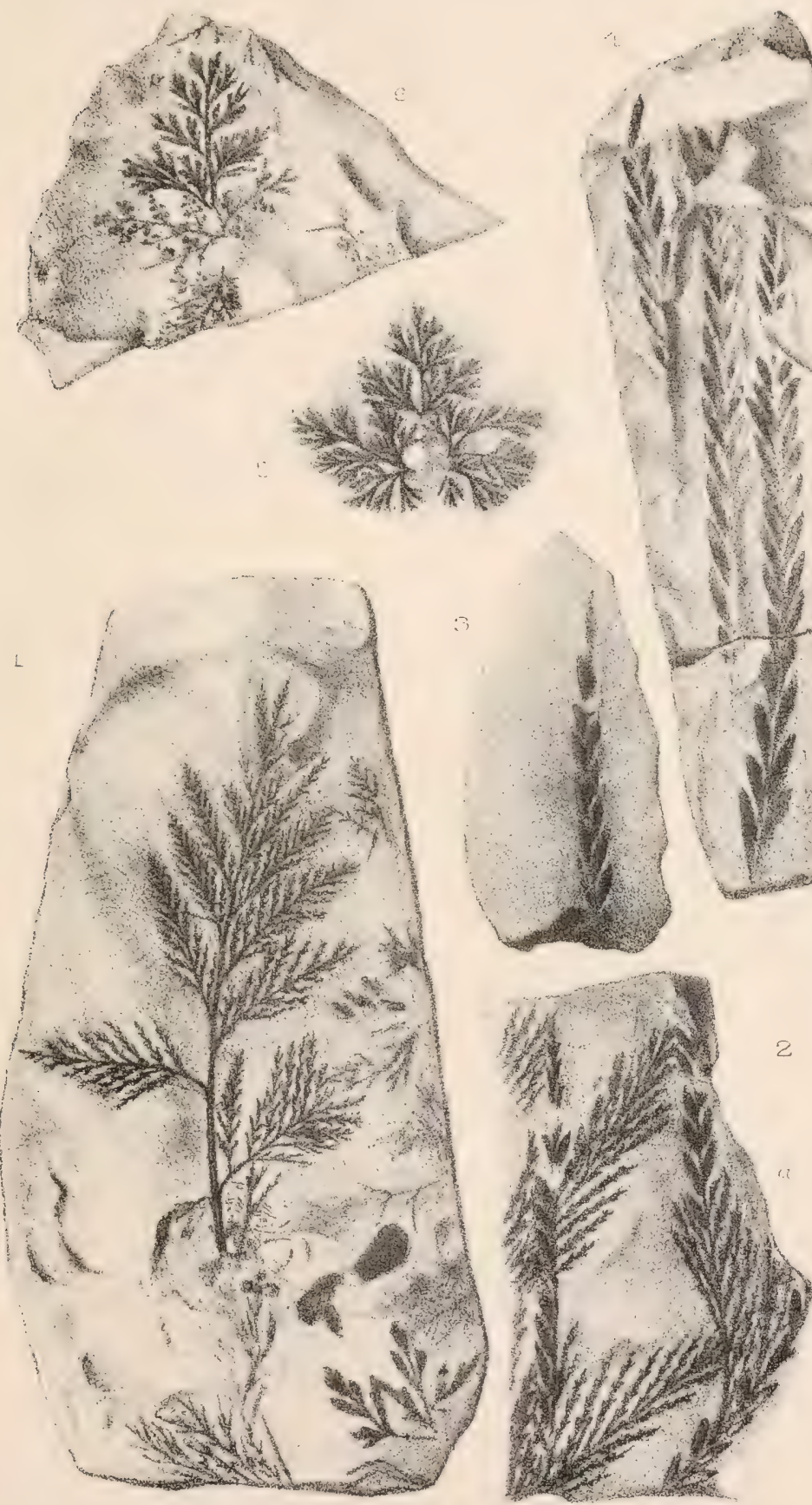




\section{PLATE IV.}

Ruffordia Göpperti (Dunk.). Finely divided form of frond. From a photograph by Mr. Gepp. Page 81. [V. 2157.] 


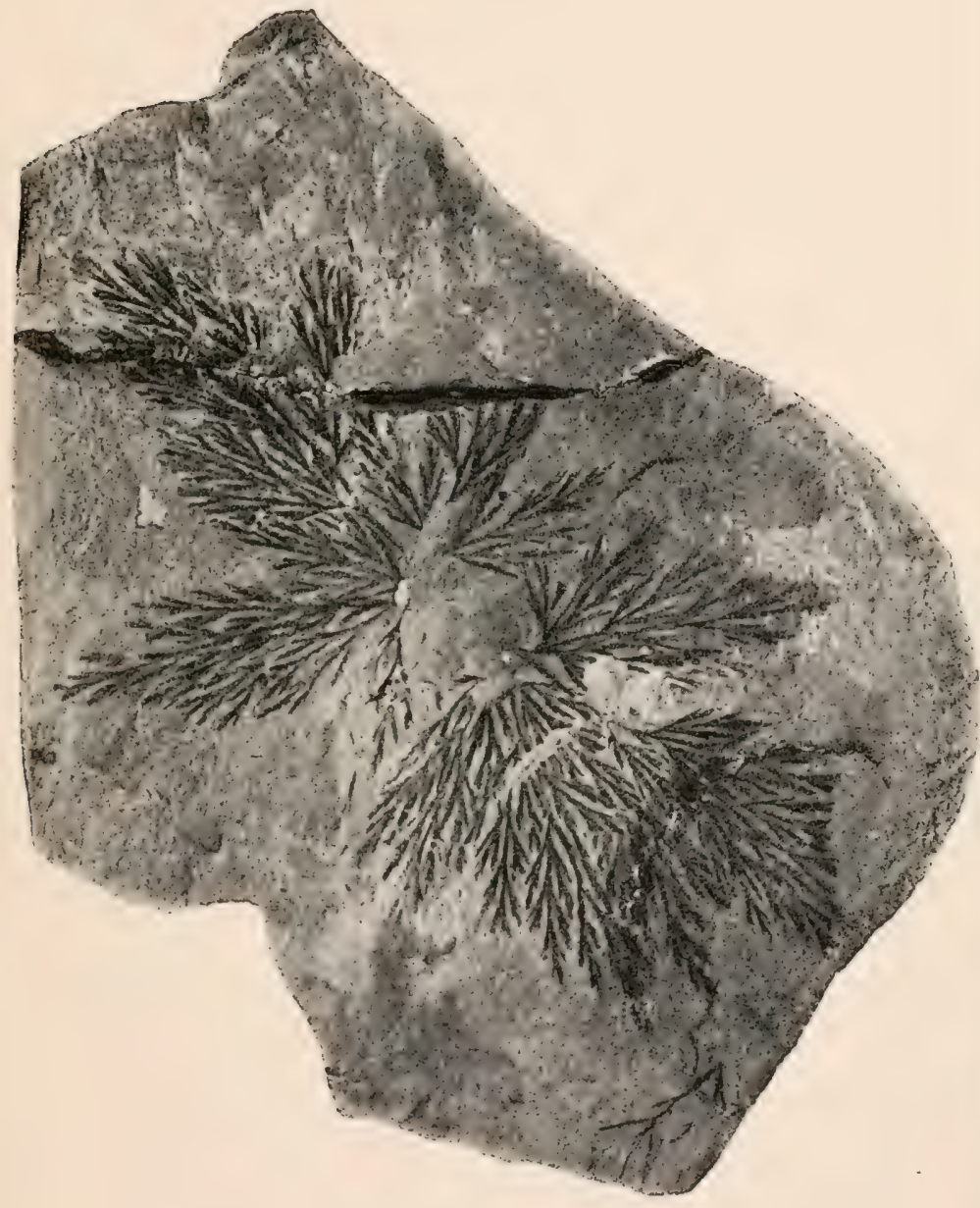

A. Gepp phot. ad nat.

Ruffordia Göpperti (Dunk.). 




\section{PLATE T.}

Frg. 1. Ruffordia Göpperti (Dunk.). Single pinna. Page 82.

[V. 2166.]

Frg. 2. Ruffordia Göpperti (Dunk.). Pieces of pinnæ. P. 82.

[V. 2155u.]

FrG. 3. Ruffordia Göpperti (Dunk.).

A. Single? pinna.

B. Portions of two pinnæ with ultimate segments broader than in the preceding figures. P. 82 . [V. 2156.]

FIG. 4. Ruffordia Göpperti (Dunk.). Part of a frond with broader segments. P. 82 .

[V. 2243.]

FIG. 5. Ruffordia Göpperti (Dunk.). Part of a fertile pinna. P. 83.

[V. 2160.] 

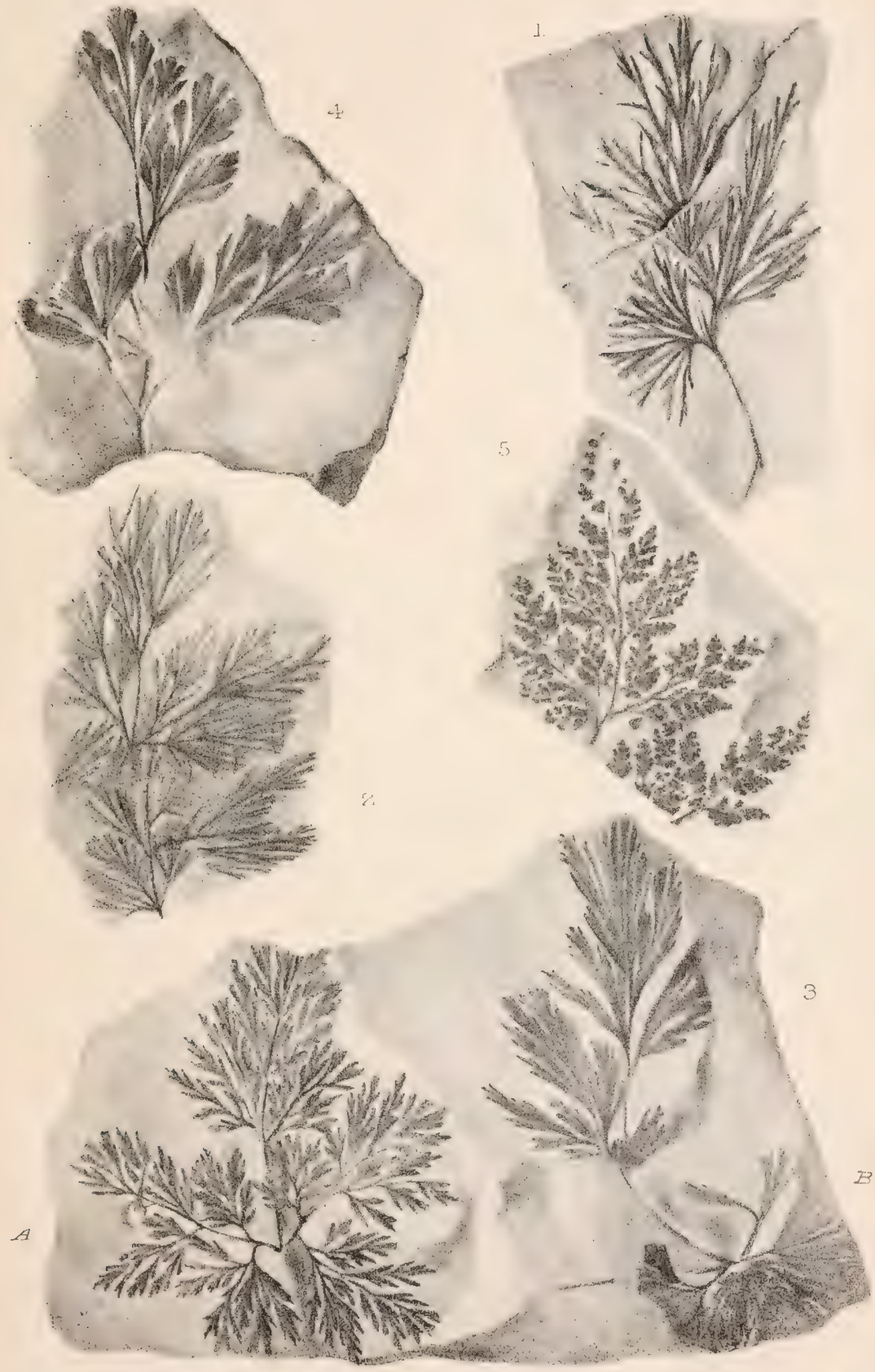

E.C \& G.M. Woodward del. et bet.

West ile-man imp.

Ruffordia. Seward. 




\section{PLA'TE VI.}

FIG. 1. Ruffordia Göpperti (Dunk.), var. latifolia. Piece of a frond with pinnules and venation very clearly preserved. Page 85.

FIG. 1a. A piece of a pinna enlarged to show the venation. P. 85. [V. 2333.]

FIG. 2. Sphenopteris Fittoni, sp. nov. Two specimens of fronds. P. 107. [V. 2242.]

FIG. 3. Acrostichopteris Ruffordi, sp. nov. Single pinna. P. 61.

[V. 2327 c.] 

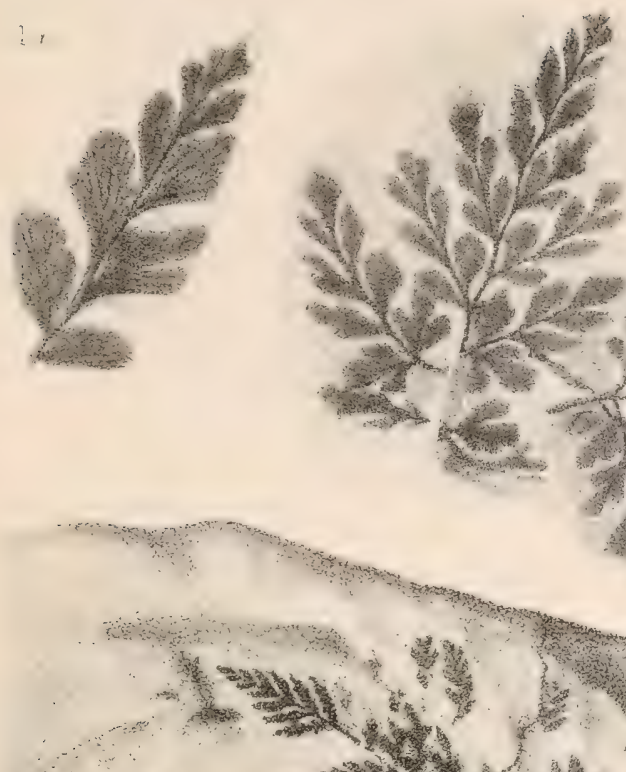

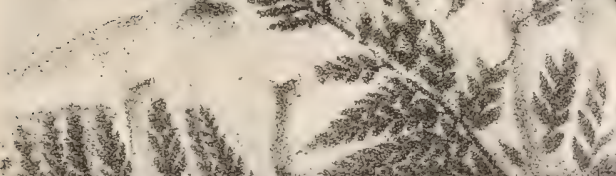
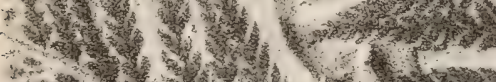

stoly

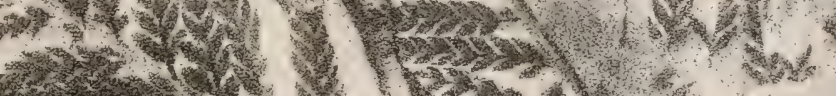
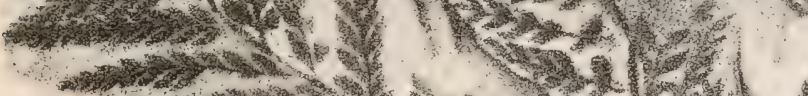

W.

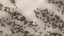

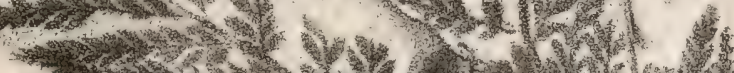

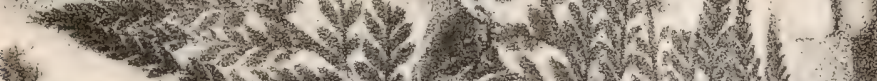

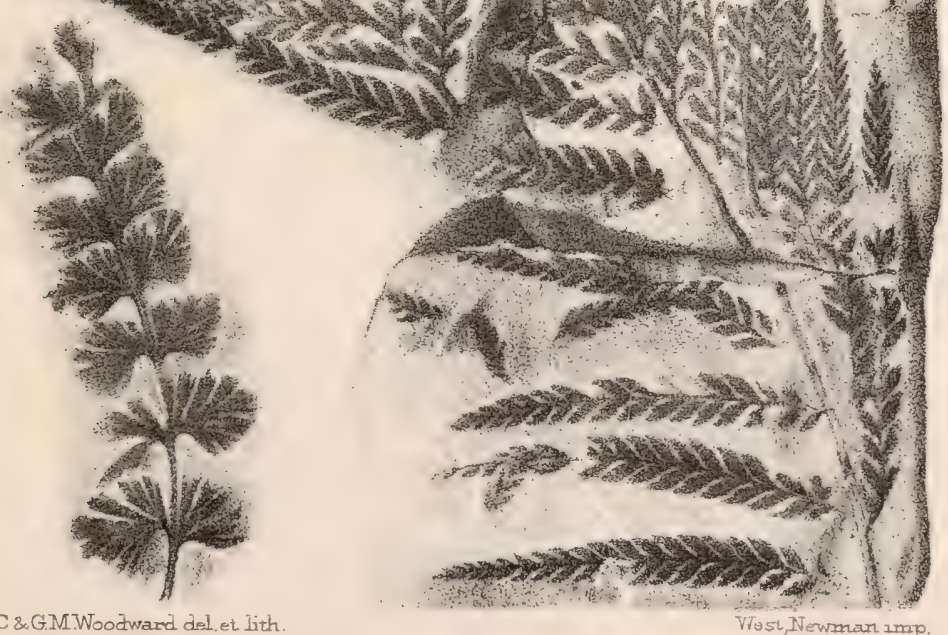

E.C \&. G.M.Woodward del et lith.

Ruffordia: Sphenopteris.

\& Acrostichopteris. 




\section{PLATE VII.}

FIG. 1. Sphenopteris Fittoni, sp. nov. Part of a frond with more divided pinnules than in Pl. VI. Fig. 2. Page 110.

[V. 2327.]

FIt. 2. Sphenopteris Fontainei, sp. nov. Portion of pinna or small frond. P. 106.

[V. 2155.]

FIG. 3. Cladophlebis Dunkeri (Schimp.). Frond frugnents showing passage from bipinnate to tripinnate form. P. 103.

[V. 2377.]

Fig. 4. Cladophlebis Browniance (Dunker). Piece of a bipinnate frond. P. 100 .

[V. 2198.]

Fis. 5. Nathorstia valdensis, gen. et sp. nov. Part of a bipinnate ? frond. P. 147.

[V. 2809.] 


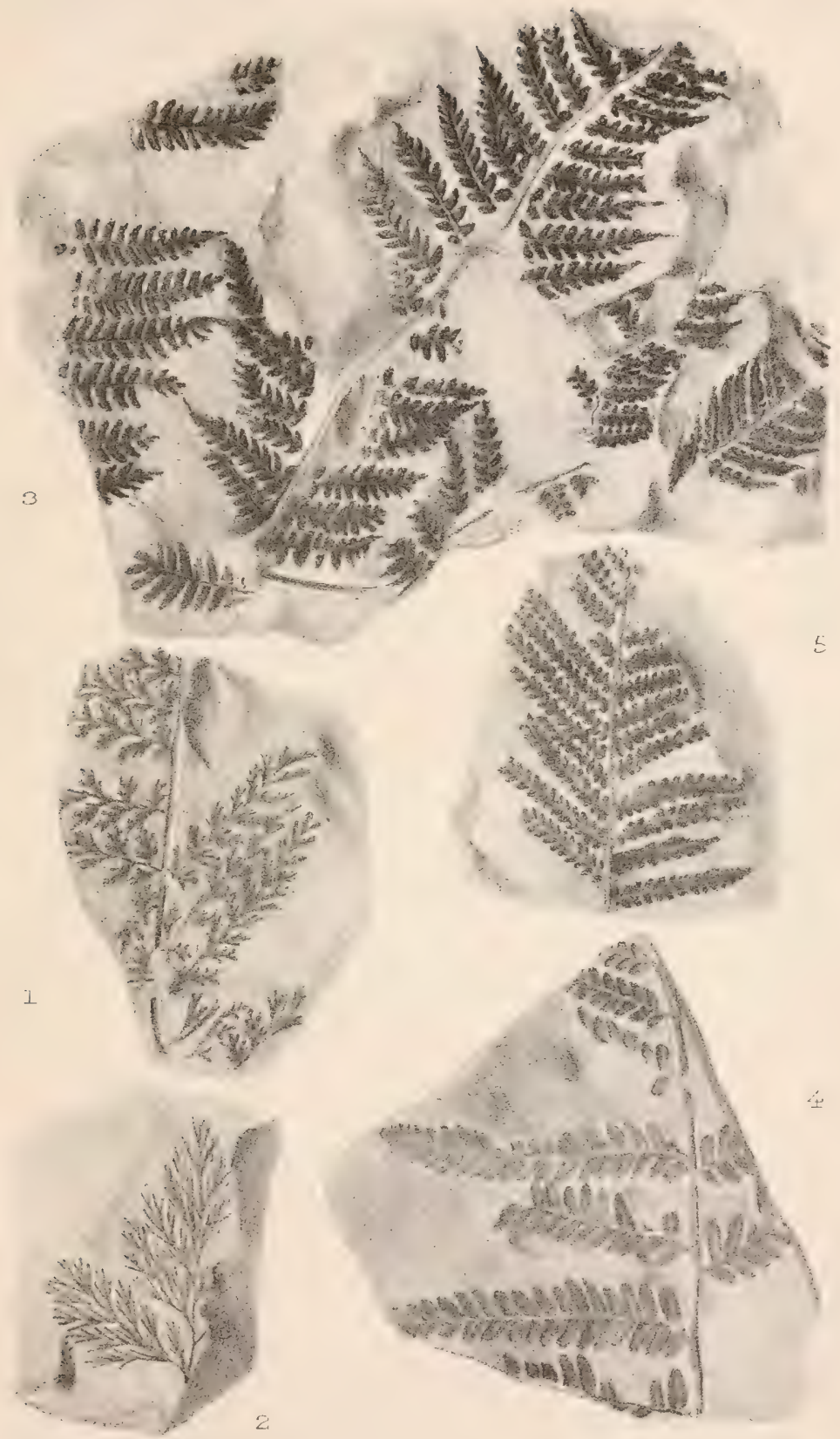

E.C\& G M.Woodward del. et lith.

Sphenopteris, Cladophlebis, \& Nathorstia. 


PLATE VIII.

Cludophlebis Albertsii (Dunk.). Large specimen of frond; two-thirds natural size. From a photograph by Mr. Gepp. Page 96.

[V. 2794.] 


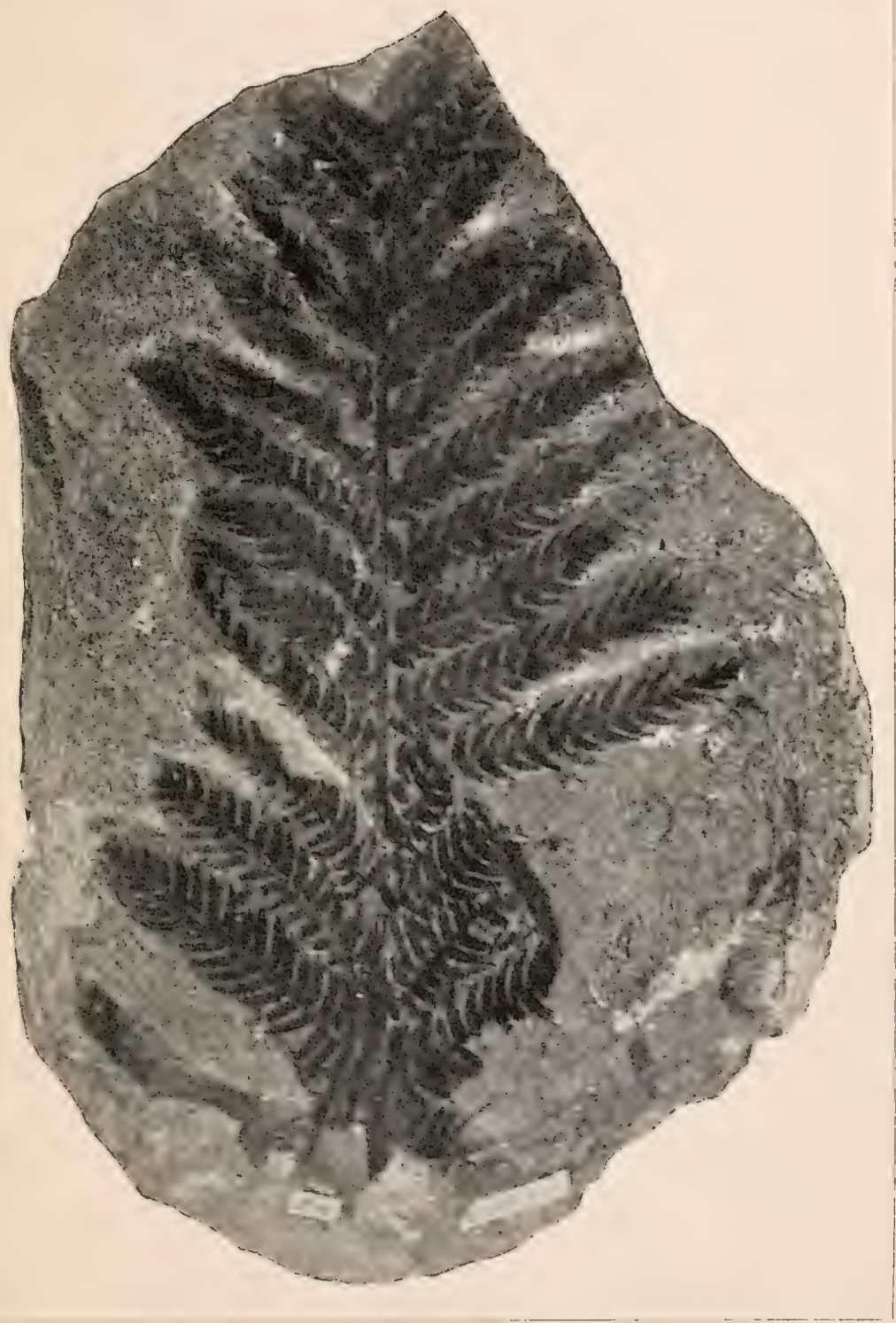

A. Gepp phot. ald nat.

Cladophlebis Albertsii (Dunk.). 




\section{PLATE IX.}

Fiu, 1. Cladophlebis longipennis, sp. nov. Single pimma. Page 89.

FIc. 1 $\alpha$. Pinnule enlarged, showing venation very clearly. P. 89.

[V. 2204.]

Fra. 2. Nathorstia valdensis, gen. et sp. nov. Part of a frond. P. 147.

FIG. $2 a$. Three pinnules enlarged; no distinct veins shown. P. 147.

[V. 2376.]

FIG. 3. Teniopteris Beypichii (Schenk). Imperfect frond. P. 126.

FIt. $3 \alpha$. Part of the leaf showing venation more clearly. P. 126.

[V. 2381.]

FIG. 4. Sagenopteris Mantelli (Dunk.). Four leaflets in their natural position; the fifth, or middle one of the three uppermost, being a detached leaflet from another frond. P. 133. [V. 2272.]

FIG. 5. Sagenopteris Mantelli (Dunk.). Single leaflet showing renation very clearly. Slightly enlarged. P. 133.

[V. 2353.]

FIG. 6. Phyllopteris acutifolia, sp. nov. Imperfect leaf. P. 143.

[V. 2816.] 

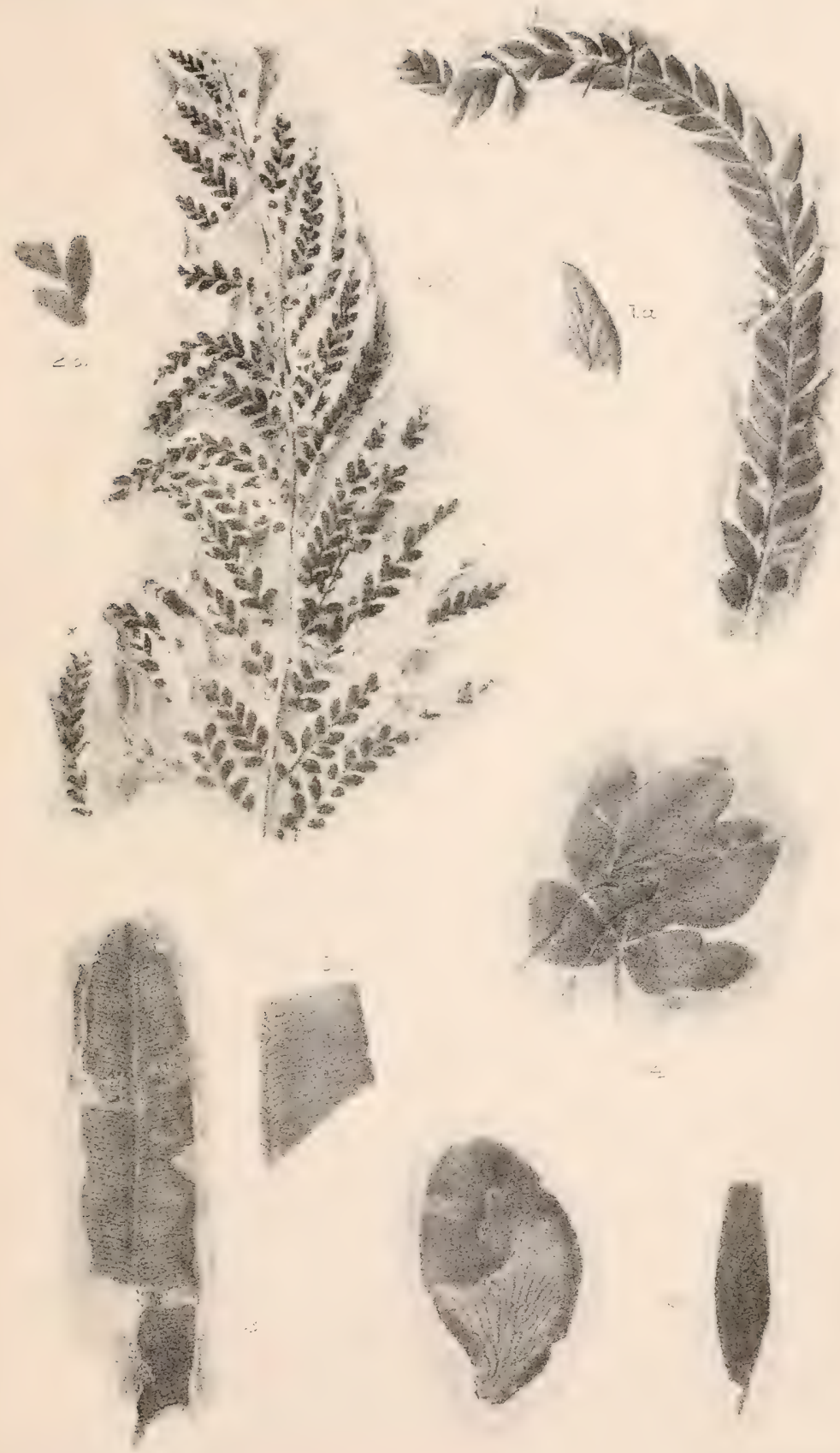

C \&. G.MWoodward del. et lith.
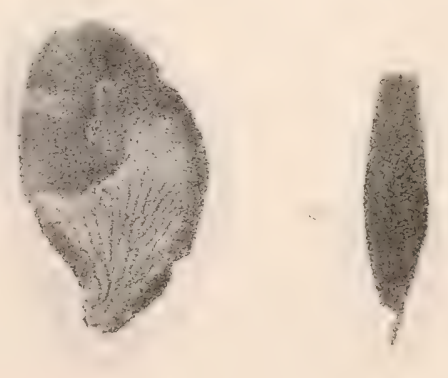

Cladophlebis, Nathorstia \& Sagenopteris. 


PLATE $\mathrm{X}$.

Fig. 1. Ruffordia Göpperti (Dunk.). Rhizome and portions of fronds. Page 83.

[V. 2731.]

FIG. 2. Ruffordia Göpperti (Dunk.). Part of rhizome and petioles. P. 83.

[V. 2812.]

FIG. 3. Weichselia Mantelli (Brong.). Large specimen of frond, long pinnæ with inclined pinnules. P. 119.

[V. 2630.] 


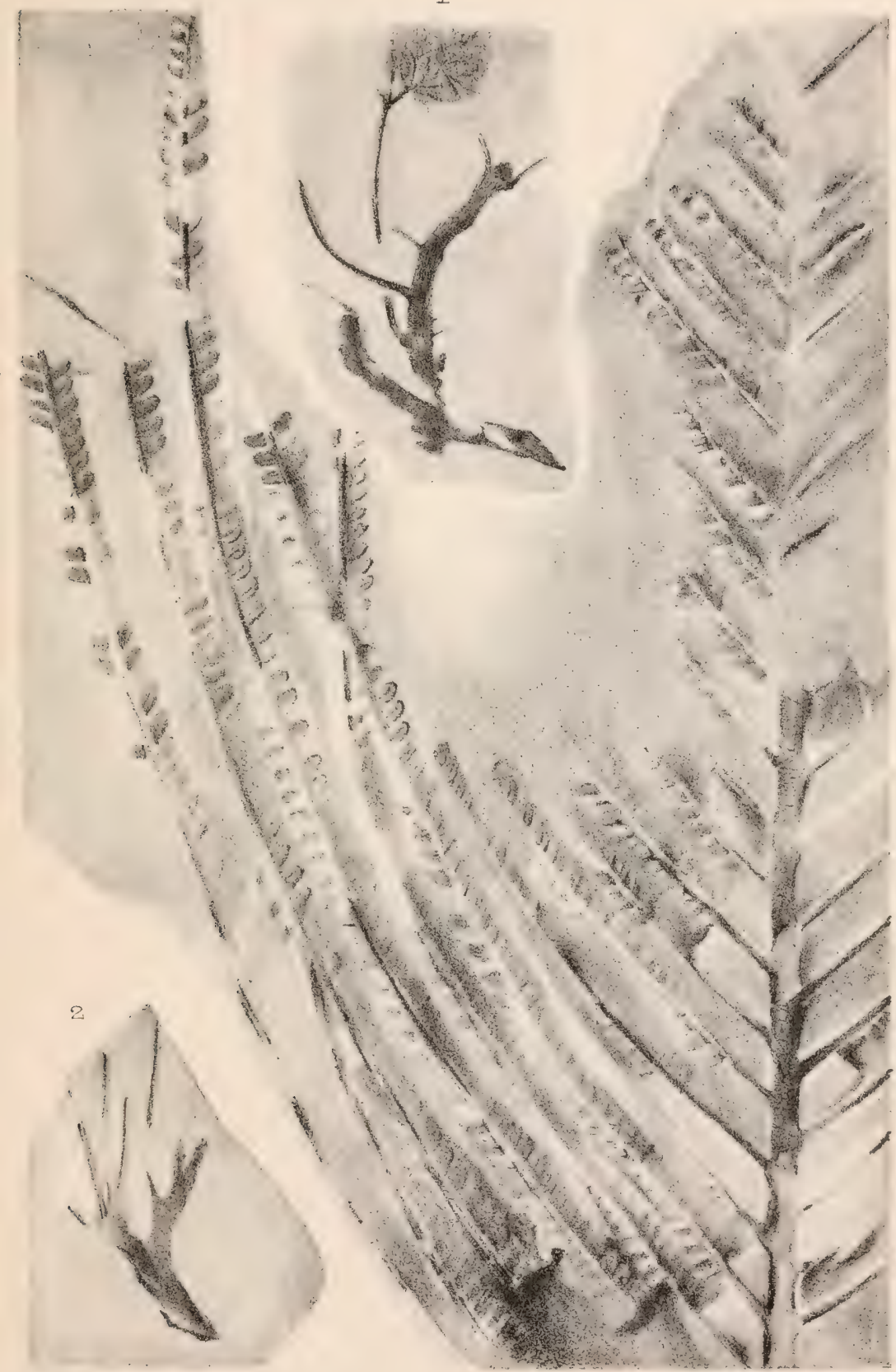

E.C \& G.M.Woodward del en liw

West,Newmarimp.

Puffordia \& Weichselia. 




\section{PLATE XI.}

FIc. 1. Protopteris Witteane, Sehenk. Portion of a stem axis showing leaf-bases and adventitious roots, etc. Page 73.

Probably Mantell Coll.

FIG. 2. The upper surface of Fig. 1 showing the form and arrangement of the vascular bundles. P. 73.

FIG. 3. A single leaf-scar with the characteristic leaf-trace bundle. P. 73.

Fig. 4. Small piece of a stem vascular bundle. Magnitied 45 times. P. 73.

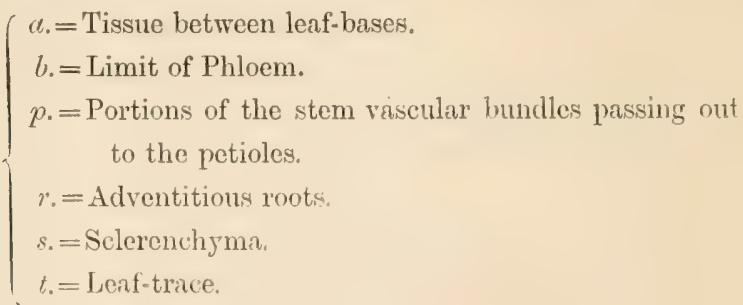




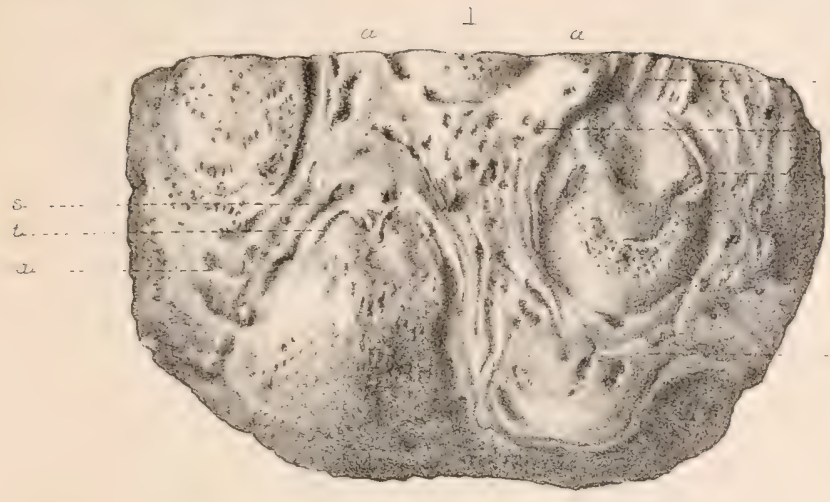

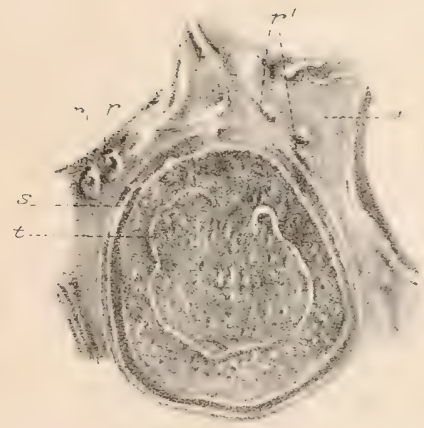

3

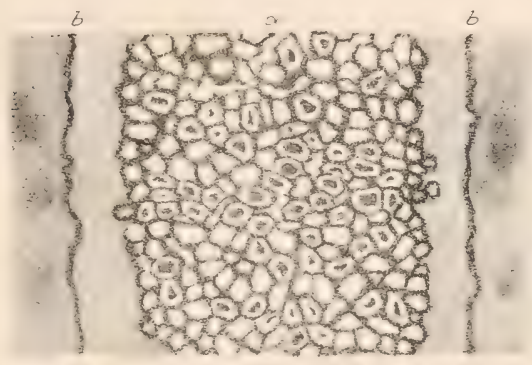

$\therefore$

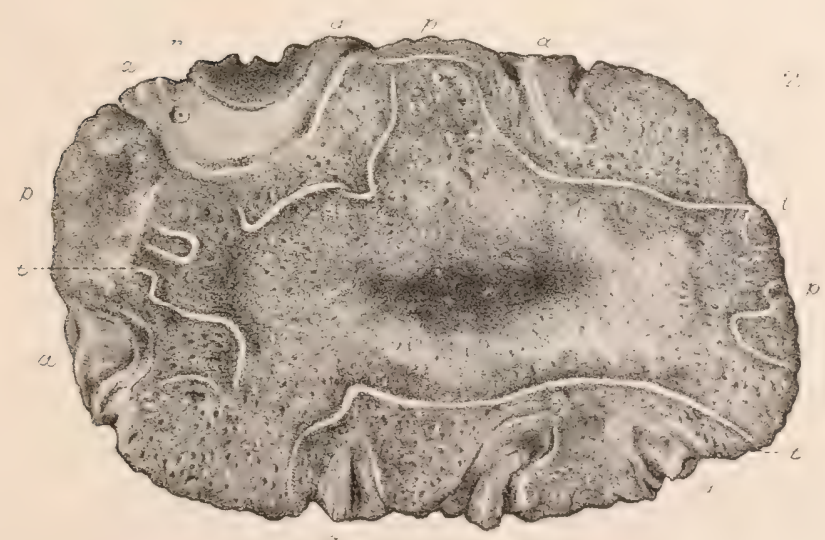

E.C \& G.M.Woodward del etitt.

We, Nennian $1 \mathrm{mi}$ 



\section{NATURAL HISTORY PUBLICATIONS OF THE TRUSTEES OF THE BRITISH MUSEUM.}

The following publications can be purchased through the Agency of Messrs. Tunguaxs d Co., 39, Paternoster Row; Mr. Quartich, 15, Piccadilly; Messis. Kegan Paul, 'Trench, 'Trübner \& Co., Paternoster House, Charing Cross Road; and Messrs. Dulau \& Co., 37, Soho Square; or at the Naturat History Museun, Cromwell Road, London, S.WW.

Catalogue of the Specimens and Drawings of Mammals, Birds, Reptiles, and Fishes of Nepal and Tibet. Presented by B. H. Hodgson, Esq., to the British Musenm. 2nd edition. By John Edward Gray. Pp. xii., 90. [With an account of the Collection by Mr. Hodgson.] 1863, 12mo. 2s. 3d.

Report on the Zoological Collections made in the Indo-Pacific Ocean during the voyage of H.M.S. "Alert," 1881-2. Pp. xxv., 684. 54 Plates, 1884, 8vo.

Summary of the Voyage - By Dr. R. W. Coppinger.

Mammalia - - - , O. Thomas.

Ares - - - ", R. B. Sharpe.

Reptilia, Batrachia, Pisces - " A. Günther.

Mollusca - - - , E. A. Smith.

Echinodermata - - " F. J. Bell.

Crustacea - - $\quad$ - ".. E. J. Miers.

Coleoptera - - - " C. O. Waterhouse.

Lepidoptera - - - "A. G. Butler.

Alcyonaria and Spongiida - ", S. O. Ridley.

1l. $10 s$.

\section{MAMMALS.}

Catalogue of the Bones of Mammalia in the Collection of the British Museum. By Edward Gerrard. Pp. iv., 296. 1862, 8 vo. $5 s$.

Catalogue of Monkeys, Lemurs, and Fruit-eating Bats in the Collection of the British Museum. By Dr. J. E. Gray, F.R.S., \&c. Pp. viii., 137. 21 Woodeuts. 1870, 8vo. 4s.

Catalogue of Carnivorous, Pachydermatous, and Edentate Mam. malia in the British Museum. By John Edward Gray, F.R.S., \&e. Pp. vii., 398. 47 Woodeuts. 1869, 8vo. 6s. $6 d$. 
Hanci-List of Seals, Morses, Sea-Lions, and Sea-Bears in the British Museum. By Dr. J. E. Gray, F.R.S., \&c. Pp. 43. 30 Plates of Skulls. 1874, 8vo. 12s, $6 d$.

Catalogue of Seals and Whales in the British Museum. By John Edward Gray, F.R.S., \&c. 2nd edition. Pp. vii., 402. 101 Woodcuts. 1866,8 vo. $8 s$.

- Supplement. By John Edward Gray, F.R.S., \&c. Pp. vi., 103. 11 Woodeuts. 1871,8 vo. $2 s, 6 d$.

List of the Specimeils of Cetaces in the Zoological Department of the British Museum. By William Henry Flower, LL.D., F.R.S., \&c. [With Systematic and Alphabetical Indexes.] Pp. iv., 36. 1885, 8vo. 1s. 6d.

Catalogue of Ruminant Mammalia (Pecora, Linnæus) in the British Museum. By John Edward Gray, F.R.S., \&e. Pp. viii., 102. 4 Plates. 1872,8 vo. 3s. $6 d$.

Hand-List of the Edentate, Thick-skinned, and Ruminant Mammals in the British Museum. By Dr. J. E. Gray, F.R.S., \&c. Pp. vii., 176. 42 Plates of Skulls, \&c. 1873, 8vo. 12 s.

Catalogue of the Marsupialia and Monotremata in the Collection of the British Museum. By Oldfield Thomas. Pp. xiii., 401. 4 coloured and 24 plain Plates. [With Systematic and Alphabetical Indexes.] 1888,8 vo. $1 l .8 s$.

\section{BIRDS.}

Catalogue of the Birds in the British Museum :-

Vol. III. Catalogue of the Passeriformes, or Perching" Birds, in the Collection of the British Museum. Coliomorpha, containing the families Corrida, Paradiseida, Oriolidæ, Dicruridæ, and Prionopidæ. By R. Bowdler Sharpe. Pp. xiii., 343. Woodcuts and 14 coloured Plates. [With Systematic and Alphabetical Indexes.] 1877,8 vo. $17 s$.

Vol. IV. Catalogue of the Passeriformes, or Perching Birds, in the Collection of the British Museum. Cichlomorphe: Part I., containing the families C'ampophagida and Muscicapidæ. By R. Bowdler Sharpe. Pp. xvi., 494. Woodcuts and 14 coloured Plates. [With Systematic and Alphabetical Indexes.] 1879, 8vo. $1 l$.

Vol. V. Catalogue of the Passeriformes, or Perching Birds, in the Collection of the British Mnseum. Cichlomorphe: Part II., containing the family Turdidæ (Warblers and Thrushes). By Henry Seebohm. Pp. xvi., 426. Woodeuts and 18 coloured Plates. [With Systematic and Alphabetical Indexes.] 1881, 8vo. $1 l$. 
Catalogue of the Birds in the British Museum-continued.

Vol. VI. Catalogue of the Passeriformes, or Perching Birds, in the Collection of the British Museum. Cichlomorpha: Part III., containing the first portion of the family Timeliidæ (Babbling Thrushes). By R. Bowdler Sharpe. Pp. xiii., 420. Woodeuts and 18 coloured Plates. [With Systematic and Alphabetical Indexes.] 1881,8 vo. $1 l$.

Vol. VII. Catalogue of the Passeriformes, or Perching Birds, in the Collection of the British Museum. Cichlomorphe: Part IV., containing the concluding portion of the family Timeliidæ (Babbling Thrushes). By $\mathrm{R}$. Bowdler Sharpe. Pp. xvi., 698. Woodcuts and 15 coloured Plates. [With Systematic and Alphabetical Indexes.] 1883, 8vo. $1 l$. 6s.

Vol. VIII. Catalogue of the Passeriformes, or Perching Birds, in the Collection of the British Museum. Cichlomorphe: Part V., containing the families Paridx and Laniidæ (Titmice and Shrikes); and Certhiomorphe (Creepers and Nuthatches). By Hans Gadow, M.A., Ph.D. Pp. xiii., 386. Woodcuts and 9 coloured Plates. [With Systematic and Alphabetical Indexes.] 1883, 8vo. $17 s$.

Vol. IX. Catalogue of the Passeriformes, or Perching Birds, in the Collection of the British Museum. Cinnyrimorphce, containing the families Nectariniidæe and Meliphagidx (Sun Birds and Honey-eaters). By Hans Gadow, MI.A., Ph.D. Pp. xii., 310. Woodcuts and 7 coloured Plates. [With Systematic and Alphabetical Indexes.] 1884, 8 vo. $14 s$.

Vol. X. Catalogue of the Passeriformes, or Perching Birds, in the Collection of the British Museum. Fringilliformes: Part I., containing the families Dicæidæ, Hirundinidæe, Ampelidæ, Mniotiltidæ, and Motacillidx. By R. Bowdler Sharpe. Pp. xiii., 682. Woodeuts and 12 coloured Plates, [With Systematic and Alphabetical Indexes.] 1885. 8 vo. $1 l .2 s$.

Vol. XI. Catalogue of the Passeriformes, or Perching Birds, in the Collection of the British Museum. Fringilliformes: Part II., containing the families Cœrebidæ, Tauagridæ, and Icteridæ. By Philip Lutley Sclater, M.A., F.R.S. Pp. xvii., 431. [With Systematic and Alphabetical Indexes.] Woodeuts and 18 coloured Plates. 1886, 8vo.1l.

Vol. XII. Catalogue of the Passeriformes, or Perching Birds, in the Collection of the British Museum. Fringilliformes: Part III., containing the family Fringillide. By R. Bowdler Sharpe. Pp. xv., 871. Woodeuts and 16 coloured Plates, [With Systernatic and Alphatetical Indexes.] 1888, 8vo. 1l. 8 s.

Vol. XIII. Catalogue of the Passeriformes, or Perching Birls, in the Collection of the British Museum. Sturni- 
Catalogue of the Birds in the British Musemm-continued. formes, containing the families Artamidæ, Sturnidæ, Ploceidæ, and Alaudidæ. Also the families Atrichiidæ and Menuridæ. By R. Bowdler Sharpe. Pp. xvi., 701. Woodcuts and 15 coloured Plates. [With Systematic and Alphabetical Indexes.] 1890, 8vo., $1 l .8 s$.

Vol. XIV. Catalogue of the Passeriformes, or Perching Birds, in the Collection of the British Museum. Oligomyoda, or the families Tyrannidæ, Oxyrhamphidæ, Pipridæ, Cotingidæ, Phytotomidæ, Philepittidæ, Pittidæ, Xenicielæ, and Eurylæmidæ. By Philip Lutiey Sclater, M.A., F.R.S. Pp. xix., 494. Woodents and 26 coloured Plates. [With Systematic and Alphabetical Indexes.] 1888,8 vo. $1 l .4 s$.

Vol. XV. Catalogue of the Passeriformes, or Perching Birds, in the Collection of the British Mnseum. Tracheophona, or the families Dendrocolaptidæ, Formicariidæ, Conopophagidæe, and Pteroptochidre. By Philip Lutley Sclater, M.A., F.R.S. Pp. xvii., 371. Woodeuts and 20 coloured Plates. [With Systematic and Alphabetical Indexes.] 1890, 8vo. $1 l$.

Vol. XV1. Catalogue of the Picarix in the Collection of the British Museum. Upupa and Trochili, by Osbert Salvin. Coracice, of the families Cypselidx, Caprimulgidit, Porlargidx, and Steatornithida, by Ernst Hartert Pp. xvi. 703. Woodcuts and 14 coloured Plates. [With Systematic and Alphabetical Indexes.] 1892, 8vo. $1 l .16 s$.

Vol. XVII. Catalogue of the Picarix in the Collection of the British Museum. Coracice (contin.) and Halcyones, with the families Leptosomatidæ, Coraciidæ, Meropidæ, Alcedinidx, Momotidx, 'Totidx, and Coliidx, by R. Bowdler Sharpe. Bucerotes and Trogones, by W. R. Ogilvie Grant. Pp. xi., 522. Woodeuts and 17 coloured Plates. [With Systematic and Alphabetical Indexes.] 1892, 8vo. 1l. $10 \mathrm{~s}$.

Vol. XVIII. Catalugue of the Picarize in the Collection of the British Museum. Scansores, containing the family Picidæ. By Edward Hargitt. Pp. xv., 597. Woodeuts and 15 coloured Plates. [With Systematic and Alphabetical Indexes.] 1890, 8 vo. 1l.6s.

Vol. XIX. Catalogue of the Picaria in the Collection of the British Museum. Scansores and Coccyges : containing the familier Rhamphastidie, Galbulide, and Bucconidx, by I'. L. Sclater; and the familie- Indicatoridx, Capitonidx, Cuculidx, and Musophagidx, by G. E. Shelley. Pp. xii., 484: 13 coloured Plates. [With Systematic and Alphabetical Indexes.] 1891, 8vo. 1l.5s.

Vol. XX. Catalogue of the Psittaci, or Parrots, in the Collection of the British Museum. By 'T. Salvadori. 
Pp. xvii., 658 : woodeuts and 18 colnured Plates. [With Systematic and Alphabetical Indexes.] 1891, 8vo. 1l. 10s.

Vol. XXI. Catalogue of the Columbæ, or Pigeons, in the Collection of the British Museum. By T. Salvadori. Pp. xvii., 676: 15 coloured plates. [With Systematic and Alphabetical Indexes.] 1893, 3vo. 1l. 10s.

Vol. XXIJ. Catalogue of the Game Birds ('Pterocletes, Galline, Opisthocomi, Hemipodii), in the Collection of the British Museum. By W. R. Ogilvie Grant. Pp. xvi., 585: 8 coloured plates. [With Systematic and Alphabetical Indexes.] 1893, 8vo. 1l.6s.

Hand-List of Genera and species of Birds, distinguishing those contained in the British Museum. By G. R. Gray, F.R.S., \&e. :-

Part II. Conirostres, Scansores, Columbx, and Gallinx. Pp. xv., 278. ['Table of Genera and Subgenera: Part II.] 1870, 8vo. 6s.

Part III. Struthiones, Grallæ, and Anseres, with Indices of Generic and Specific Names. Pp. xi., 350. [Table of Genera and Subgenera: Part III.] 1871, 8vo. 8 s.

List of the Specimens of Birls in the Collection of the British Museum. By George Robert Gray:-

Part III., Sections III. and IV. Capitonidæ and Picidæ. [With Index.] Pp. 137. 1868, 12mo. 1s.6d.

Part IV. Columbæ. [With Index.] Pp. 73. 1856, 12mo. ]s. $9 d$.

Part V. Gallinæ. Pp. iv., 120. [With an Alphabetical Index.] 1867, 12mo. $1 \mathrm{~s} .6 \mathrm{~d}$.

Catalogue of the Birds of the Tropical Islands of the Pacific Ocean in the Collection of the British Museum. By George Robert Gray, F.L.S., \&c. Pp. 7\%. [With an Alphabetical Index.] 1859, 8vo. 1s.6d.

\section{REPTILES.}

Catalogue of the Tortoises, Crocodiles, and Amphisbanians in the Collection of the British Museum. By Dr. J. E. Gray, F.R.S., \&e. Pp. viii., 80. [With an Alphabetical Index.] 1844, 12mo, $1 s$.

Catalogue of Shield Reptiles in the Collection of the British Museum. By John Edward Gray, F.R.S., \&e. :-

Part I. Testudinata (Tortoises). Pp. 79. 50 plates. 1855, 4to. 2l. 10s.

Supplement. With Figures of the Skulls of 36 Genera. Pp. ix., 120. 40 Woodeuts. 1870, 4to. 10s.

Appendix. Pp. 28. 1872, 4tc. 2s. 6d.

Part II. Enydosaurians, Rhynchocephalia, and Amphishenians. Pp. vi., 41. 25 iVondents. 1872, 4to. 3s. 6d. 
Hand-List of the Specimens of Shield Reptiles in the British Museum. By Dr. J. E. Gray, F.R.S., F.L.S., \&c. Pp. iv., 124. [With an Alphabetical Index.] 1873, 8vo. 4s.

Catalogue of the Chelonians, Rhynchocephalians, and Crocodiles in the British Museum (Natural History). New Edition. By George Albert Boulenger. Pp. x., 311. 73 Woodcuts and 6 Plates. [With Systematic and Alphabetical Indexes.] 1889, 8ro. $15 s$.

Gigantic Land Tortoises (living and extinct) in the Collection of the British Museum. By Albert C. L. G. Günther, M.A., M.D., Ph.D., F.R.S. Pp. iv., 96. 55 Plates, and two Charts of the Aldabra group of Islands, north-west of Madagascar. [With a Systematic Srnopsis of the Extinct and Living Gigantic Land 'Tortoises.] 1877, 4to. 1l. 10s.

Catalogue of the Lizards in the British Museum (Natural History). Second edition. By George Albert Boulenger :-

Vol. I. Geckonidæe, Eublepharidæ, Uroplatidæ, Pygopodidæ, Agamidæ. Pp. xii., 436. 32 Plates. [With Systematic and Alphabetical Indexes.] 1885, 8vo. 20s.

Vol. II. Iguanidæ, Xenosauridæ, Zonuridæ, Anguidæ, Anniellidæ, Helodermatidæ, Varanidæ, Xantusiidæ, Teiidæ, Amphisbænidæ. Pp. xiii., 497. 24 Plates. [IVith Systematic and Alphabetical Indexes.] 1885, 8vo. 20s.

Vol. III. Lacertidx, Gerrhosauridæ, Scincidæ, Anelytropidæ, Dibamidæ, Chamæleontidæ. Pp. xii., 575. 40 Plates. [With a Systematic Index and an Alphabetical Index to the three volumes.] $1887,8 v 0.17 .6 s$.

Catalogue of the Snakes in the British Museum (Natural History). Vol. I., containing the families Typhlopidx, Glauconiidx, Boidx, Ilysiidæ, Uropeltidæ, Xenopeltidæ, and Colubridæe aglyphæ, part. By George Albert Boulenger. Pp. xiii., 448. 26 Woorlcuts and 28 plates. [With Systematic and Alphabetical Indexes.] 1893, 8vo. 1l. $1 s$.

Catalogue of Colubrine Snakes in the Collection of the British Museum. By Dr. Albert Günther. Pp. xvi., 281. [With Geographical, Systematic, and Alphahetical Indexes.] 1858, $12 \mathrm{mo} .4 s$.

\section{BATRACHIANS.}

Catalogue of the Batrachia Salientia in the Collection of the British Museum. By Dr. Albert Günther. Pp. xri., 160. 12 Plates. [With Systematic, Geographical, and Alphabetical Indexes.] 1858, 8vo. 6s. 
Catalogue of the Batrachia Salientia, s. Ecaudata, in the Collection of the British Museum. Second Edition. By George Albert Boulenger. Pp. xvi., 503. Woodeuts and 30 Plates. [With Srstematic and Alphabetical Indexes.] 1882, 8ro. 1l. $10 \mathrm{~s}$.

Catalogue of the Batrachia Gradientia, s. Caudata, and Batrachia Apoda in the Collection of the British Museum. Second edition. By George Albert Boulenger. Pp. viii., 127. 9 Plates. [With Systematic and Alphabetical Indexes.] 1882, 8vo. $9 s$.

\section{FISHES.}

Catalogue of the Fishes in the Collection of the British Museum.

By Dr. Aibert Günther, F.R.S., \&c. :-

Vol. III. Acanthopterygii (Gobiida', Discoboli, Oxudercidr, Batrachidæ, Pediculati, Blenniidæ, Acanthoclinidæ, Comephoridx, Prachypterilie, Lophotida, Teuthididæ, Acronuridx, Hoplognathidæ, Malacanthida, Nandidx, Polycentrida, Labyrinthici, Luciocephalida, Atherinida, Mugilida, Ophioeephalidx, Trichonotide, Cepolidx, Gobiesocidæ, Psychrolutidæ, Centriscidæ, Fistularidæ, Mastacembelidæ, Notacanthi). Pp. xxv., 586. Woodcuts. [With Systematic and Alphabetical Indexes, and a Systematic Synopsis of the families of the Acanthop. terygian Fishes.] 1861, 8vo., 10s. 6d.

Vol. IV. Acanthopterygii pharyngognathi and Anacanthini. Pp. xxi., 534. [With Systematic and Alphabetical Indexes.] 1562, 8vo. 8s. 6 d.

Vol. V. Physostomi (Siluridx, Characinidx, Haplochitonidx, Sternoptychidx, Scopelidæ, Stomiatidx). Pp. xxii., 455. Woodcuts. [With Systematic and Alphabetical Indexes.] 1864, 8vo. 8s.

Vol. VII. Physostomi (Heterophygii, Cyprinidæ, Gonorhynchidæ, Hyodontidæ, Osteoglossidæ, Clupeidæ, Chirosentridx, Alepocephalidx, Notopteridx, Halosauridæ). Pp. xx, 512. Woodcuts. [With Systematic and Alphabetical Indexes.] 1968, 8vo. 8s.

Vol. VIII. Plyysostomi (Gymnotidæ, Symbranchidæ, Murænidre, Pegasidie), Lophobranchii, Plectognathi, Dipnoi, Ganoidei, Chondropterygii, Cyclostomata, Leptocardii. Pp. xxv., 549. [With Systematic and Alphabetical Indexes.] 1870,8 vo. $8 s .6 d$.

List of the Specimens of Fish in the Collection of the British Museum. Part I. Chondropterygii. By J. E. Gray. Pp. x., 160. 2 Plates. [With Systematic and Alphabetical Indexes.] 1851, 12mo. $3 s$.

Catalogue of Fish collected and described by Laurence 'Theodore Gronow, now in the British Museum. Pp. vii., 196. [With a Systematic Index.] 1854, 12mo. $3 s .6 d$. 
Catalogue of. Lophobranchiate Fish in the Collection of the British Museum. By J. J. Kaup, Ph.D., \&c. Pp. iv., 80. 4 Plates. [With an Alphabetical Index.] 1856, $12 \mathrm{mo} .2 s$.

\section{MOLLUSCA.}

Guide to the Systematic Distribution of Mollusca in the British Museum. Part I. By John Edward Gray, Ph.D., F.R.S., \&c. Pp. xii., 230. 121 Woodeuts. 1857,8 vo. 5 s.

Catalogue of the Collection of Mazatlan Shells in the British Museum, collected by Frederick Reigen. Described by Philip P. Carpenter. Pp. xvi., 552. 1557, 12mo. 8s.

List of Mollusca and Shells in the Collection of the British Museum, collected and described by MM. Eydoux and Souleyet in the "Voyage autour du Monde, exécuté pendant les années " 1836 et 1837, sur la Corvette "La Bonite," " and in the "Histoire naturelle des Mollusques Ptéropodes," Par MMI. P. C. A. L. Rang et Souleyet. Pp. iv., 27. 1855, 12mo. 8d.

Catalogue of Pulmonata, or Air Breathing Mollusca, in the Collection of the British Museum. Part I. By Dr. Louis Pfeiffer. Pp. iv., 192. Woodcuts. 1855, 12mo. 2s. $6 d$.

Catalogue of the Auricnlidx, Proserpinidx, and Truncatellide in the Collection of the British Museum. By Dr. Lonis Pfeiffer. Pp. iv., 150. Woodcuts. 1857, 12mo. 1s.9d.

List of the Mollusca in the Collection of the British Museum. John Edward Gray, Ph.D., F.R.S., \&c.

Part I. Volutidæ. Pp. 23. 1855, 12mo. 6d.

Part II. Olividæ. Pp. 41. 1865, 12mo. 1s.

Catalogue of the Conchifera, or Bivalve Shells, in the Collection of the British Museum. By M. Deshayes :-

Part 1. Veneridæ, Cyprinidx, Glauconomidx, and Petri. coladæ. Pp. iv., 216. 1853, 12mo. 3s.

Part II. Petricoladæ (concluded); Corbiculadæ. . Pp. 217-292. [With an Alphabetical Index to the two parts.] 1854, $12 \mathrm{mo} .6 d$.

\section{BRACHIOPOIAA.}

Catalogue of Brachiopoda Aneylopoda or Lamp Shells in the Collection of the British Museum. [Issued as "Catalogue of the Mollusca, Part IV."] Pp. iv., 128. 25 Woodents. [With an Alphabetical Index.] 1853, $12 \mathrm{mo} .3 s$.

\section{POLYZOA.}

Catalogue of Marine Polyzoa in the Collection of the British Museum. Part III. Cyclostomata. By George Busk, F.R.S. Pp viii., 39. 38 Plates, [With a Systematic Index.] 1875, Sro. 5 s. 


\section{CRUSTACEA.}

Catalogue of Crustacea in the Collection of the British Mruseum. Part I. Leucosiadæ. By Thomas Bell, V.P.R.S., Pres. L.S., \&c. Pp. iv., 24. 1855, 8vo. 6 d.

Catalogue of the Specimens of Amphipodous Crustacea in the Collection of the British Museum. By C. Spence Bate, F.R.S., dc. Pp. ir., 399. 5o Plates. [With an Alphabetical Index.] 1862, 8vo. $1 l .5 s$.

\section{INSECTS}

\section{Coleopterous Insects.}

Nomenclature of Coleopterous Insects in the Collection of the British Museum :-

Part V. Cucujidx, \&c. By Frederick Smith. [Also issued as "List of the Coleopterous Insects. Part I."] Pp. 25. 1851, 12mo.6d.

Part VI. Passalidæ. By Frederick Smith. Pp. iv., 23. 1 Plate. [With Index.] 1852, 12mo. 8d.

Part VII. Longicornia, I. By Adam White. Pp. iv., 174. 4 Plates. $1853,12 \mathrm{mo} .2 s .6 d$.

Part VIII. Longicornia, II. By Adam White. Pp. 237. 6 Plates. $1855,12 \mathrm{mo} .3 s .6 d$.

Part IX. Cassilidie. By Charles H. Boheman, Professor of Natural History, Stockholm. Pp.225. [With Index.] $1856,12 \mathrm{mo} .3 s$.

Illustrations of Typical Specimens of Coleoptera in the Collection of the British Musem. Part I. Lycidx. By Charles Owen Waterhouse. Pp. x., 83. 18 coloured Plates. [With Systematic and Alphabetical Indexes.] 1879, 8vo, 16s.

Catalogue of the Coleopterous Insects of Madeira in the Collection of the British MInseum. By T. Vernon Wollaston, M.A., F.L.S. Pp. xvi., 234: 1 plate. [With a Topographical Catalogue and an Alphabetical Index.] 1857, 8vo. $3 s$.

Catalogue of the Coleopterous Insects of the Canaries in the Collection of the British Museum. By T. Vernon Wollaston, M.A., F.L.S. Pp. xiii.,61s. [Vith 'Topographical and Alphahetical Indexes.] $1864,8 \mathrm{vo} .10 \mathrm{~s}, 6 \mathrm{~d}$.

Catalogue of Halticide in the Collection of the British Musenn. By the Rev. Hamlet Clark, M.A., F.L.S. Physaporles and Edipodes. Part I. Pp. xii., 301. Frontispiece and 9 Plates. 1860,8 vo. $7 s$.

Catalogne of Hispidie in the Collection of the British MInsenm. By Joseph S. Baly, M.E.S., \&c. Part I. Pp. x., 172. 9 Plates. [With an Alphabetical Index.] 1858, 8vo. (is. 


\section{Hymenopterous Insects.}

('italogue of Hymenopterous Insects in the Collection of the British Museum. By Frederick Smith. 12mo.:-

Part I. Andrenidre and Apidæe. Pp. 197. 6 Plates. 1853, $2 s .6 d$.

Part II. Apidæ. Pp. 199-465. 6 Plates. [With an Aiphabetical Index.] 1854, 6s.

Part III. Mutillidæ and Pompilidæ. Pp. 206. 6 Plates. 1855, 6s.

Part IV. Sphegidæ, Larridæ, and Crabronidæ. Pp. 207497. 6 Plates. [With an Alphabetical Index.] 1856, 6s.

Part V. Vespidre. Pp. 147. 6 Plates. [With an Alphabetical Index.] 1857, 6 s.

Part VI. Formicidæ. Pp. 216. 14 Plates. [With an Alphabetical Index.] 1858, $6 s$.

Part VII. Dorylidx and Thynnida. Pp. 76. 3 Plates. [With an Alphabetical Index.] $1859,2 s$.

J)escriptions of New Species of Hynenoptera in the Collection of the British Museum. By Frederick Smith. Pp. xxi., 240. [With Systematic and Alphabetical Indexes.] 1879, 8ro. 10 s.

List of Hymenoptera, with descriptions and figures of the Typieal Specimens in the British Museum. Tol. I., Tenthredinidre and Siricidæ. By W. F. Kirby. Pp. xxviii,, 450. 16 coloured I'lates. [With Systematic and Alphahetical Indexes.] 1882, 8vo. 1 l. 18 s.

\section{Dipterous Insects.}

List of the Specimens of Dipterous Insects in the Collection of the British Museum. By Francis Walker, F.L.S. 12mo.:-

Part II. Pp. 23l-484. 1849, 3s. 6rl.

Part IV. Pp. 689-1172. [With an index to the four parts, and an Index of Donors.] 1849. Gs.

Part V. Supplement I. Stratiomidx, Xylophagidx, and Tabanidx. Pp. iv., 330. 2 Cuts. 1854. 4s. $6 d$.

Part VI. Supplement II. Acroceridxe and part of the family Asilidæ. Pp. ii., 331-506. 8 Cuts. 1854. $3 s$.

Part VII. Supplement III. Asilidie. Pp. ii., 507-775 1855. 3s. 6 l.

\section{Lepidopterous Insects.}

Illustrations of Typical Specimens of Lepidoptern Heterocera in the Collection of the British Museum:-

Part I. By Arthur Gardiner Butler. Pp. xiii,, 62, 20 Coloured Plates. [With a Systematic Index.] 1877, 4to. $2 l$. 
Illustrations of Typical Specimens of Lepidoptera IItetecera, \&c.-continued.

Part III. By Arthur Gardiner Butler. Pp. xviii., 82. 41-60 Coloured Plates. [With a Systematic Index.] 1879, 4to. 2l. 10s.

Part V. By Arthur Gardiner Butler. Pp. xii., 74. 78-100 Coloured Plates. [With a Systematic Index.] 1881, 4to. $2 l .10 \mathrm{~s}$.

Part VI. By Arthur Gardiner Butler. Pp. xv., 89. 101-120 Coloured Plates. [With a Systematic Index.] 1886, 4to. $2 l .4 s$.

Part VII. By Arthur Gardiner Butler. Pp. iv., 124. 121-138 Coloured Plates. [With a Systematic List.] 1889,4 to. $2 l$.

Part VIII. The Lepidoptera Heterocera of the Nilgiri District. By George Francis Hampson. Pp. iv., 144. 139-156 Coloured Plates. [With a Systematic List.] 1891,4 to. $2 l$.

Part IX. The Macrolepidoptera Heterocera of Ceylon. By George Francis Hampson. Yp. v., 182. 157-176 Coloured Plates. [With a General Systematic List of Species collected in, or recorded from, Ceylon.] 1893, 4 to. $2 l .2 s$.

Catalogue of Diurnal Lepicloptera of the family Satyridx in the Collection of the British Museum. By Arthur Gardiner Butler, F.L.S., \&e. Pp. vi., 211. 5 Plates. [With an Alphabetical Index.] 1868,8 vo. $5 s .6 d$.

Catalogne of Diurnal Lepidoptera described by Fabricins in the Collection of the British MLuseum. By Arthur Gardiner Butler, F.L.S., \&c. Pp. iv., 303. 3 Plates. 1869, 8vo. 7s.6d.

Specimen of a Catalogue of Lycanidx in the British Museum. By W. C. Hewitson. Pp. 15. 8 Coloured Plates. 1862, 4to. 1l. 1 s.

List of Lepiclopterous Insects in the Collection of the British Museum. Part I. Papilionidæ. By G. R. Gray, F.L.S. Pp. 106. [With in Alphabetical Ind̄ex.] 1856, 12mo. $2 s$.

List of the Specimens of Lepidopterons Tnsects in the Collection of the British Museum. By Francis Walker. 12mo.:-

Part VI. Lepidoptera Heterocera. Pp. 1258-1507. 1855, $3 s .6 d$.

Part XIX. Pyralides. Pp. 799-1036. [With an Alphabetical Index to Parts XVI.-XIX.] 1859, $3 s .6$.

Part XX. Geometrites. Pp. 1-276. 1860, 4 s.

Part XXI. - Pp. 277-498. 1860, 3s.

Part XXII. — Pp. 499-755. 1861, 3s.6d.

Part XXIII. —— P P. 756-1020. 1861, 3s.6d.

Part XXIV. — - Pp. 1021-1280. 1862, 3s.6d.

Part XXV. - Pp. 1281-1477. 1862, 3 s.

Part XXVI. _- _ Pp. 1478-1796. [With an Alphabetical Index to Parts XX.-XXVI.] 1862 , 4s. 6 r . 
List of the Specimens of Lepidopterous Insects, \&c.-continuer.

Part XXVII. Crambites and Tortricites. Pp. 1-286. $1863,4 s$.

Part XXVIII. Tortricites and Tineites. Pp. 287-561. $1863,4 s$.

Part XXIX. Tineites. Pp. 562-835. 1864, $4 s$.

Part XXX. Pp. 836-1096. [With an Alphabetical Index to Parts XXVII.-XXX.] 1864, $4 s$.

Part XXXI. Supplement. Pp. 1-321. 1864, 5s.

Part XXXII. - Part 2. Pp. 322-706. 1865, $5 s$.

Part XXXIII. 1865, 6s.

Part XXXIV. $1865,5 s .6 d$.

Part XXXV. Part 3. Pp. 707-1120. Part 4. Pp. 1121-1533.

Part 5. Pp. 1534-2040. [With an Alphabetical Index to Parts XXXI.-XXXV.] $1866,7 s$.

\section{Neuropterous Insects.}

Catalogue of the Specimens of Neuropterous Insects in the Collection of the British Museum. By Francis Walker. 12mo. :-

Part I. (Phryganides-Perlides.) Pp. iv., 192. 1852, $2 s .6 d$.

Part II. Sialidæ-Nemopterides. Pp. ii., 193-476. $1853,3 s, 6 d$.

Part III. Termitidæ-Ephemeridæ. Pp. ii., 477-585. 1853, 1s. 6d.

Part IV. Odonata. Pp. ii., 587-658. 1853, 12mo. $1 s$. Catalogue of the Specimens of Neuropterous Insects in the Collection of the British Museum. By Dr. H. Hagen. Part I. Termitina. Pp. 34. 1858, 12mo. 6d.

\section{Orthopterous Insects.}

Catalogue of Orthopterous Insects in the Collection of the British Museum. Part I. Phasmidx. By John Obadiah Westwood, F.L.S., \&c. Pp. 195. 48 Plates. [With an Alphabetical Index.] 1859, 4to. $3 l$.

Catalogue of the Specimens of Blattaria in the Collection of the British Museum. By Francis Walker, F.L.S., \&c. Pp. 239. [With an Alphabetical Index.] 1868, 8vo. 5s, 6d.

Catalogue of the Specimens of Dermaptera Saltatoria [Part I.] and Supplement to the Blattarie in the Collection of the British Museum. Gryllidæ. Blattariæ. Locustidæ. By Francis Walker, F.L.S., \&c. Pp. 224. [With an Alphabetical Index.] 1869,8 vo. $5 s$. 
Catalogue of the Specimens of Dermaptera Saltatoria in the Collection of the British Museum. By Francis Walker, F.L.S., \&e.-

Part II. Locustidæ (continued). Pp. 225-423. [With an Alphabetical Index.] 1869, 8vo, 4s, $6 d$.

Part III. Locustidæ (continued).-Acrididæ. Pp. 425604. [With an Alphabetical Index.] 1870, 8ro. $4 s$.

Part IV. Acrididæ (continued). Pp. 605-809. [With an Alphabetical Index.] 1870, 8vo. 6s.

Part V. Tettigidæ.-Supplement to the Catalogue of Blattariæ.- Supplement to the Catalogue of Dermaptera Saltatoria (with remarks on the Geographical Distribution of Dermaptera). Pp. 811-850; 43; 116. [With Alphabetical Indexes.] 1870, 8vo. 6s.

\section{Hemipterous Insects.}

List of the Specimens of Hemipterous Insects in the Collection of the British Museum. By W. S. Dallas, F.L.S. :-

Part I. Pp. 368. 11 Plates. 1851, 12mo. $7 s$.

Part II. Pp. 369-590. Plates 12-15. 1852, 12mo. 4s.

Catalogue of the Specimens of Heteropterous Hemiptera in the Collection of the British ALuseum. By Francis Walker, F.L.S., \&e. 8vo.:-

Part I. Scutata. Pp. 240. 1867. 5s.

Part II. Scutata (continued). Pp. 241-417. 1867. 4s. Part III. Pp. 418-599. [With an Alphabetical Index to Parts I., II., III., and a Summary of Geographical Distribution of the Species mentioned.] 1868. $4 s .6 d$. Part IV. Pp. 211. [Alphabetical Index.] 1871. 6s.

Part V. Pp. 202. - 1872. 5s.

Part VI. Pp. 210. 1873. 5s.

Part VII. Pp. 213. - - 1873. 6s.

Part VIII. Pp. 220. — - 1873. 6s.6d.

\section{Homopterous Insects.}

List of the Specimens of Homopterous Insects in the Collection of the British Museum. By Francis Walker. Supplement. Pp. ii., 369. [With an Alphabetical Index.] 1858, 12mo. 4s. 6d.

\section{VERMES.}

Catalogue of the Species of Entozon, or Intestinal Worms, contained in the Collection of the British Museum. By Dr. Baird. Pp. iv., 132. 2 Plates. [With an Index of the Animals in which the Entozoa mentioned in the Catalogue are found; and an Index of Genera and Species.] 1853, 12mo. $2 s$. 


\section{AN'THOZOA.}

Catalogne of Sea-pens or P'ennatulariclse in the Collection of the British Museum. By J. E. Gray, F.R.S., \&e. Pp. iv., 40. 2 Woodeuts. $1870,8 v 0.1 s .6 d$.

Catalogue of Lithophytes or Stony Corais in the Collection of the British Museum. By J. E. Gray, F.R.S., \&c. Pp. iv., 51. 14. Woodeuts. 1870, 8 vo. $3 s$.

Catalogue of the Madreporarian Corals in the British Museum (Natural History). Vol. I. The Genus Madrepora. By George Brook. Pp, xi., 212. 35 Collotype Plates. [With Systematic and Alphabetical Indexes, Explanation of Plates, and a Preface by Dr. Günther.] 1893, 4to, $1 l .4 s$.

\section{BRITISH ANIMALS.}

Catalogue of British Birds in the Collection of the British Museum. By George Robert Gray, F.L.S., F.Z.S., \&c. Pp. xii., 248. [With a List of Species.] 1863, 8vo. 3s. 6d.

('atalogue of British Hymenoptera in the Collection of the British Museum. Second edition. Part I. Andrenidre and Apidx. By Frederick Smith, M.E.S. New Issue. Pp. xi. 236. 11 Plates. [With Systematic and Alphabetical Indexes.] 1891, 8vo. $6 s$.

Catalogue of British Fossorial Hymenoptera, Formicidx, and Vespidx in the Collection of the British Museum. By Frerlerick simith, V.P.E.S. Pp. 236. 6 Plates. [With an Alphabetical Index.] 1858, $12 \mathrm{mo} .6 s$.

A Catalogue of the British Non-parasitical Worms in the Collection of the British Museum. By George Johmston, M.D., Edin., F.R.C.I. Ed., Lu.D. Marischal Coll. Aberdeen, \&c. Pp. 365. Woodcuts and 24 Plates. [With an Alphabetical Index.] 1865,8 vo. $7 s$.

Catalogue of the British Echinoderms in the British Museum (Natural History). By F. Jeffrey Bell, M.A. Pp. xvii. 202. Woodcuts and 16 Plates (2 coloured). [With Table of Contents, 'Tables of Distribution, Alphabetical Tudex, Description of the Plates, \&c.] 1892,8 vo. $12 s .6 d$.

Lisi of the Specimens of British Animals in the Collection of the British Museum; with Symonyma and References to figures. 12mo.:-

Part V. Lepidoptera. By J. F. Stephens. 1850. 2nd Edition. By H. 'I. Stainton and E. Shepherd. Pp.iv. 224. $1856,12 \mathrm{mo}$. 1s. $9 d$.

Part VII. Mollusca, Acephala, and Brachiopoda. By Dr. J. E. Gray. Pp. iv., 167. 1851, 12mo. 3s. 6d.

Part XI. Anoplura or Parasitic Insects. By H. Denuy. Pp.iv., 51. 1852, 1 s. 
List of the Specimens of British Animals, \&e.-continued.

Part XIII. Nomenclature of Hymenoptera. By Frederick Smith. Pp. iv., 74. 1853, 12 mo. $1 s .4 d$.

Part XIV. Nomenclature of Neuroptera. By $\Lambda$ dam White. Pp. iv., 16. 1853, 12mo. 6d.

Part XV. Nomenclature of Diptera, I. By Adam White. Pp. iv., 42. 1853, $12 \mathrm{mo}$. Is.

\section{PLAN'TS.}

List of British Diatomacex in the Collection of the British Museum. By the Rev. IV. Smith, F.L.S., \&c. I'p. jv., 55. 1859, I2mo. Is.

\section{FOSSILS.}

Catalogue of the Fossil Mammalia in the British Museum (Natural History). By Richard Lydekker, B.A., F.G.S. :-

Part I. Containing the Orders Primates, Chiroptera, Insectivora, Carnivora, and Rodentia. Pp. xxx., 268. 33 Woodcuts. [With Systematic and $\mathrm{Al}_{\text {phabetical Indexes.] }}$ 1885,8 vo. $5 s$.

Part II. Containing the Order Ungulata, Suborder Artioductyla. Pp.xxii., 324. 39 Woodeuts. [With Systematic and Alphabetical Indexes. $\quad 1885,8$ vo. $6 s$.

Part III. Containing the Order Ungulata, Suborders Perissodactyla, Toxodontia, Condylarthra, and Amblypoda. Pp. xvi., 186. 30 Woodcuts. [With Systematic Index, and Alphabetical Index of Genera and species, including Synonyms.] 1886, 8vo. $4 s$.

Part IV. Containing the Order Ungulata, Suborder Proboscidea. Pp. xxiv.,235. 32 Woodeuts. [With Systematic Index, and Alphabetical Index of Genera and Species, including Synonyms.]. 1886, 8vo. 5s.

Part V. Containing the Group Tillodontia, the Orders Sirenia, Cetacea, Edentata, Marsupialia, Monotremata, and Supplement. Pp. xxxv., 345. 55 Woodcuts. [With Systematic Index, and Alphabetical Index of Genera and Species, including Synonyms.] 1887, 8vo. $6 s$.

Catalogue of the Fossil Birds in the British Museum (Natural History). By Richard Lydekker, B.A. Pp. xxvii,, 368. 75 Woodcuts. [With Systematic Index, and Alphabetical Index of Genera and Species, including Synonyms.] 1891, 8vo. 10s.6d.

Catalogue of the Fossil Reptilia and Amphibia in the British Museum (Natural History). By Richard Lydekker, B.A., F.G.S.:-

Part I. Containing the Orders Ornithosauria, Crocodilia, Dinosauria, Squamata, Rhynchocephalia, and Proterosauria. Pp. xxviii., 309. 69 Woodcuts. [With Systematic Index, and Alphabetical Index of Genera and Species, including Synonyms.] 1888, 8vo. 7s. 6d. 
Catalogue of the Fossil Reptilia aud Amphibia-continued.

Part II. Containing the Orders Ichthyopterygia and Sauropterygia. Pp. xxi., 307. 85 Woodcuts. [With Systematic Index, and Alphabetical Index of Genera and Species, including Synonyms.] 1889, 8vo. $7 s .6 d$.

Part III. Containing the Order Chelonia. Pp. xviii., 239. 53 Woodcuts. [With Systematic Index, and Alphabetical Index of Genera and Species, including Synonyms.] 1889, 8vo. $7 s .6 d$.

Part IV. Containing the Orders Anomodontia, Ecaudata, Caudata, and Labyrinthodontia; and Supplement. Pp. xxiii., 295. 66 Woodeuts. [With Systematic Index, Alphabetical Index of Genera and Species, including Synonyms, and Alphabetical Index of Genera and Species to the entire work.] 1890,8 vo. $7 s, 6 d$.

Catalogue of the Fossil Fishes in the British Museum (Natural History). By Arthur Smith Woodward, F.G.S., F.Z.S. :-

Part I. Containing the Elasmobranchii. Pp. xlvii., 474. 13 Woodeuts and 17 Plates. [With Alphabetical Index, and Systematic Index of Genera and Species.] 1889, 8vo. $21 s$.

Part II. Containing the Elasmobranchii (Acanthodii), Holocephali, Ichthyodorulites, Ostracodermi, Dipnoi, and Teleostomi (Crossopterygii and Chondrostean Actinopterygii). Pp. xliv., 567. 58 Woodeuts and 16 Plates. [With Alphabetical Index, and Systematic Index of Genera and Species.] 1891, 8vo. $21 s$.

Systematic List of the Edwards Collection of British Oligocene and Eocene Mullusea in the British Museum (Natural History), with references to the type-specimens from similar horizons contained in other collections belonging to the Geological Department of the Museum. By Richard Bullen Newton, F.G.S. Pp. xxviii., 365. [With tahle of Families and Genera, Bibliography, Correlation-table, Appendix, and Aiphabetical Index.] 1891, 8vo. 6s.

Catalogue of the Fossil Cephalopoda iu the British Museum (Natural History). By Arthur H. Foord, F.G.S.:-

Part I. Containing part of the Suborder Nautiloidea, consisting of the families Orthoceratidx, Endoceratidx, Actinoceratidx, Gomphoceratidx, Ascoceratidre, Poterioceratidx, Cyrtoceratidx, and Supplement. Pp. xxxi, 344. 51 Woodeuts. [With Systematic Index, and Alphabetical Index of Genera and Species, including Synonyms.] 1888, 8vo. $10 \mathrm{~s} .6 \mathrm{~d}$.

Part II. Containing the remainder of the Suborder Nautiloidea, cousisting of the families Lituitidat, 'Trochoceratidæ, Nautilidx, and Supplement. Pp. xxviii., 407. 86 TVoodcuts. [With Systematic Index, and Alphabetical Index of Genera and Species, induüng Synonyms.] 189 !, 8vo. $15 s$. 
A Catalogue of British Fossil Crustacea, with their Synonyms and the Range in Time of each Genus and Order. By Henry Woodward, F.R.S. Pp. xii., 155. [With an Alphabetical Index.] 1877, 8vo. 5s.

Catalogue of the Blastoidea in the Geological Department of the British Museum (Natural History), with an account of the morphology and systematic position of the group, and a revision of the genera and species. By Robert Etheridge, jun., of the Department of Geology, British Museum (Natural History), and P. Herbert Carpenter, D.Sc., F.R.S., F.L.S. (of Eton College). [With Preface by Dr. H. Woodward, Table of Contents, General Index, Explanations of the Plates, \&c.] Pp. xv., 322. 20 Plates. 1886, 4to. 25s.

Catalogue of the Fossil Sponges in the Geological Department of the British Museum (Natural History). With descriptions of new and little known species. By George Jennings Hinde, Ph.D., F.G.S. Pp. viii., 248. 38 Plates. [With a Tabular List of Species, arranged in Zoological and Stratigraphical sequence, and an Alphabetical Index.] 1883, 4to. 1l. $10 s$.

Catalogue of the Fossil Foraminifera in the British Museum (Natural History). By Professor 'T. Rupert Jones, F.R.S., \&c. Pp. xxiv., 100. [With Geographical and Alphabetical Indexes.] 1882, 8vo. 5s.

Catalogue of the Palæozoic Plants in the Department of Geology and Palæontology, British Museum (Natural History). By Robert Kidston, F.G.S. Pp. viii., 288. [With a list of works quoted, and an Index.] 1886, 8vo. $5 s$.

\section{GUIDE-BOOKS.}

\section{(To be obtained only at the Museum.)}

A General Guide to the British Museum (Natural History), Cromwell Road, London, S.W. [By W. H. Flower.] With ? Plans, 2 views of the building, and an illustrated cover. Pp. 78. 1893, 8vo. $3 d$.

Guide to the Galleries of Mammalia (Mammalian, Osteological, Cetacean) in the Department of Zoology of the British Museum (Natural History). [By A. Günther.] 4th Edition. Pp. 126. 57 Woodcuts and 2 Plans. Index. 1892, 8vo. 6d.

Guide to the Galleries of Reptiles and Fishes in the Department of Zoology of the British Museum (Natural History). [By A. Güuther.] 3rd Edition. Pp. iv. 119. 101 Woodcuts and 1 Plan. Index. 1893, 8vo. 6d.

Guide to the Shell and Starfish Galleries (Mollusca, Echinodermata, Vermes), in the Department of Zoology of the British Museum (Natural History). [By A. Günther.] 2nd Edition. Pp. iv., 74. 5l Woodeuts and 1 P.lan. 1888, 8vo. $4 d$. 
A Guide to the Exhibition Galleries of the Department of Geology and Palæontology in the British Museum (Natural History), Cromwell Road, London, S.W. [New Edition. By Henry Woodward.] -

Part I. Fossil Mammals and Birds. Pp. xii., 103. 119 Woodeuts and 1 Plan. 1890, 8vo. 6d.

Part II. Fossil Reptiles, Fishes, and Invertebrates. Pp. xii., 109. 94 Woodeuts and 1 Plan. 1890, 8vo. 6d.

Guide to the Collection of Fossil Fishes in the Department of Geology aud Palæontology, British Museum (Natural History), Cromwell Road, South Keusington. [By Henry Woodward.] 2nd Edition., Pp. 51. 81 Woodcuts. Index. 1888, 8vo. 4d.

Guide to Sowerby's Models of British Fungi in the Department of Botany, British Museum (Natural History). By Worthington G. Smith, F.L.S. Pp. 82. 93 Woodcuts. With Table of Diagnostic Characters and Index. 1893, 8vo, 4d.

A Guide to the Mineral Gallery of the British Museum (Natural History). [By L. Fletcher.] Pp. 32. Plan. 1893, 8vo. 1d.

An Introduction to the Study of Minerals, with a Guide to the Mineral Gallery of the British Museum (Natural History), Cromwell Road, S.W. [By L. Fletcher.] Pp. 120. With numerous Diagrams, a Plan of the Mineral Gallery, and an Index. 1894, 8vo. 6d.

'The Student's Index to the Collection of Minerals, British MIuseum (Natural History). New Edition. Pp. 32. With a Plan of the Mineral Gallery. 1893, 8vo. $2 d$.

An Introduction to the Study of Meteorites, with a List of the Meteorites represented in the Collection. [By L. Fletcher.] Pp. 91. [With a Plan of the Mineral Gallery, and an Index to the Metecrites represented in the Collection. I 1893, 8ro. 3d.

British Museum

\section{W. H. FLOWER,}

Director.

(Natural History),

Cromwell Road, London, S.TW.

February i 5th, 1894. 




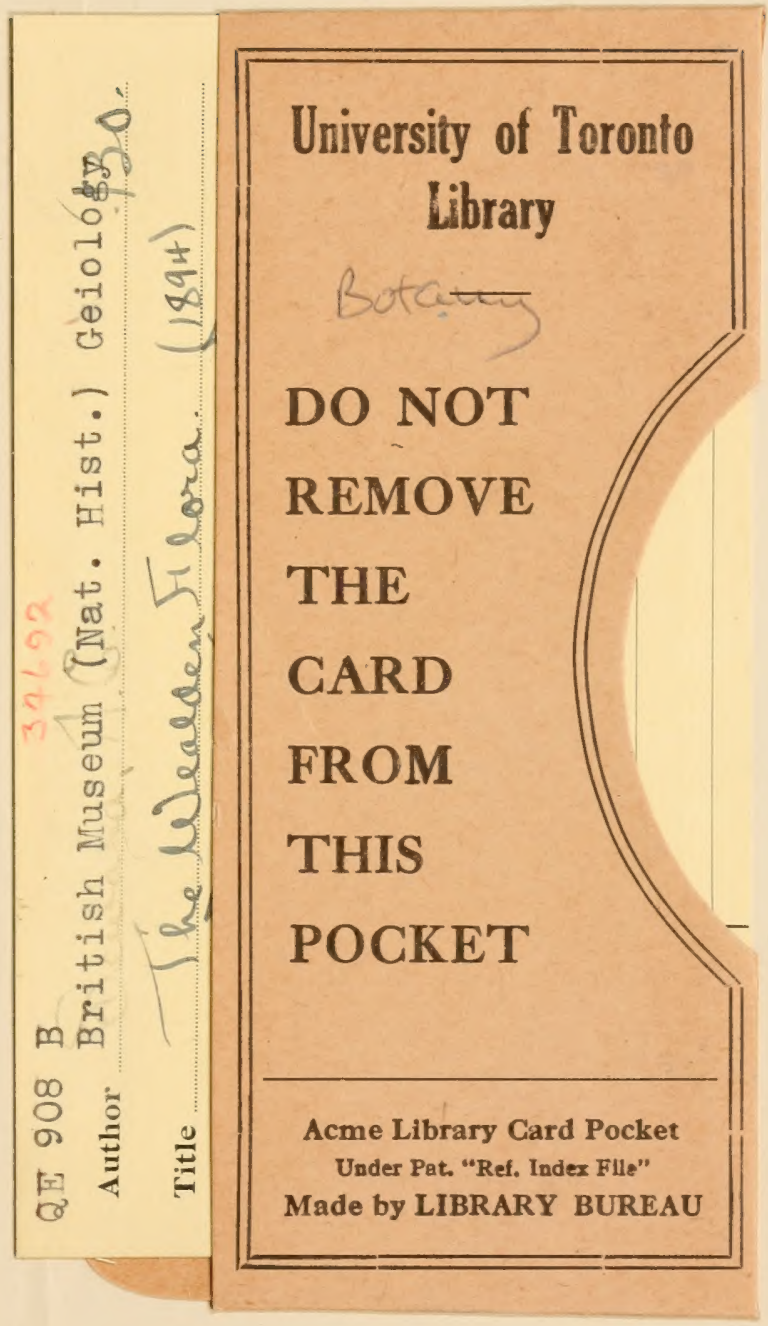




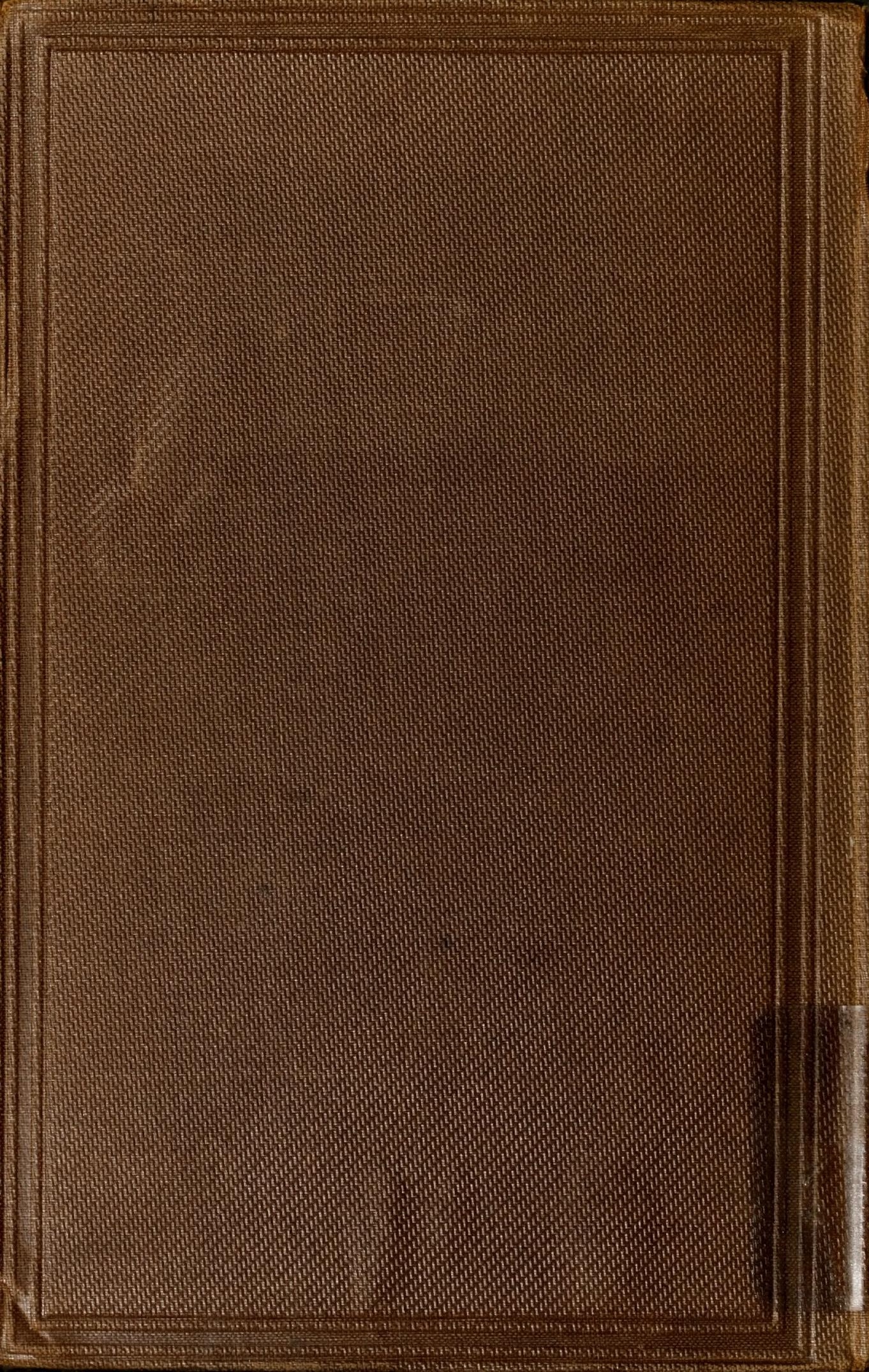

